UNIVERSIDADE DE SÃO PAULO

MUSEU DE ARQUEOLOGIA E ETNOLOGIA

PROGRAMA DE PÓS-GRADUAÇÃO EM ARQUEOLOGIA

\title{
ARQUEOLOGIA DA MORTE NO SÍTIO HATAHARA DURANTE A FASE PAREDÃO
}
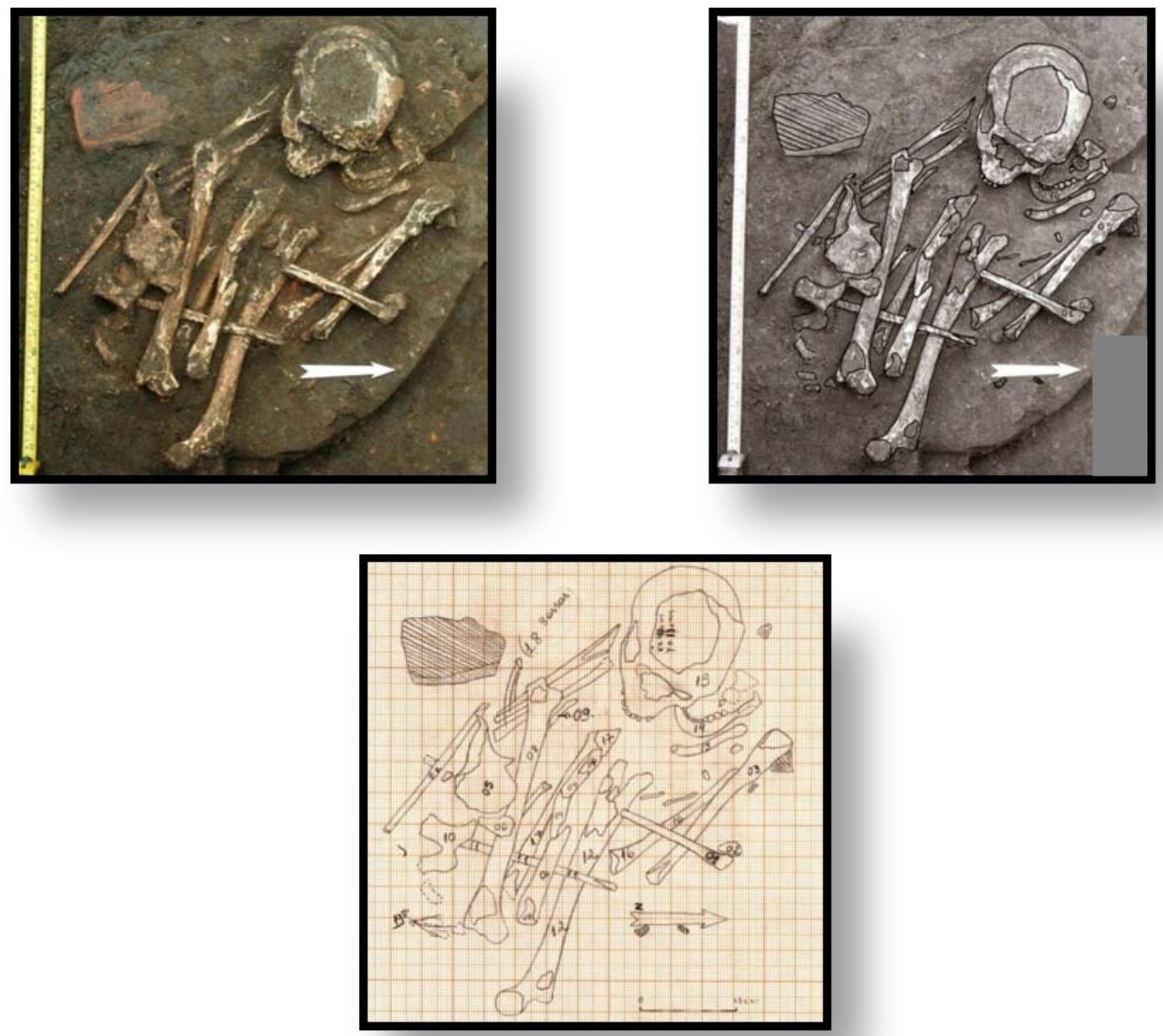

Anne Rapp Py-Daniel

São Paulo

2009 


\section{UNIVERSIDADE DE SÃO PAULO \\ MUSEU DE ARQUEOLOGIA E ETNOLOGIA \\ PROGRAMA DE PÓS-GRADUAÇÃO EM ARQUEOLOGIA}

\section{ARQUEOLOGIA DA MORTE NO SÍTIO HATAHARA DURANTE A FASE PAREDÃO}

Aluna: Anne Rapp Py-Daniel

Dissertação apresentada ao Programa de Pós-Graduação em Arqueologia do Museu de Arqueologia e Etnologia da Universidade de São Paulo para obtenção do título de Mestre em Arqueologia.

Orientador: Prof. Dr. Eduardo Góes Neves

Linha de Pesquisa: Processos de formação do registro arqueológico 
À toda minha família, que sempre me apoia em todas as minhas loucas empreitadas. Ao meu gordinho, Rafael, que me ensinou (e ensina todos os dias) que o amor é tudo. Aos meus pais. 
"Se há alguma coisa sagrada é o corpo humano"

\&

"A vida é o pouco que nos sobra da morte"

Walt Whitman 


\section{The Road Not Taken}

Two roads diverged in a yellow wood, And sorry I could not travel both And be one traveler, long I stood And looked down one as far as I could To where it bent in the undergrowth;

Then took the other, as just as fair, And having perhaps the better claim, Because it was grassy and wanted wear; Though as for that the passing there Had worn them really about the same,

And both that morning equally lay In leaves no step had trodden black. Oh, I kept the first for another day! Yet knowing how way leads on to way, I doubted if I should ever come back.

I shall be telling this with a sigh Somewhere ages and ages hence:

Two roads diverged in a wood, and II took the one less traveled by, And that has made all the difference.

Robert Frost 


\section{AGRADECIMENTOS}

Esse mestrado só pode se realizar com a ajuda de várias pessoas, tanto diretamente como indiretamente.

Para começar agradeço à minha família (Lúcia, Victor, Zé Carlos, tia Ruth, tio Jean-Claude, Cidany, tia Ana, tio Paulinho, tia Anna, tio Tadeu, Karen, Tainã, Sarah, Raquel e primos e cunhados), sem a qual eu não teria escrito uma linha dessa dissertação. O apoio (psicológico, emocional, acadêmico, financeiro, etc.) de todos tem sido essencial. MUITO OBRIGADA!!!! MERCI BEAUCOUP!!!! THANK YOU!!!!! GRACIAS!!!!

Agradeço especialmente ao meu marido e filho: Claide, por me guiar nos meus momentos de dúvidas (e eles foram muitos!) e me ensinar muito sobre a arqueologia; Rafael, por deixar a minha vida “mais feliz”.

Agradeço ao meu orientador, Eduardo Góes Neves (Edu), e ao PAC pela oportunidade de trabalhar na Amazônia Central em um dos sítios mais excepcionais que eu já conheci! A todos os participantes desse projeto e outros tantos que me ajudaram a realizar esse mestrado de maneiras diferentes no campo e no laboratório (sem ordem): Claide, Nina, Bernardo, Francini, Vinícius (Girino), Bruna, Marcos (Marquito), Guilherme (gaúcho), Thiago (Pitoco), Eduardo Kazuo, Márjorie, Elaine, Fernando (Caminhão), Edimar (Seu Nego), Myrtle, Alexia, Cláudio (Crovis), Hermenegildo (Seu Bené), Lei, Francisco (Pupunha), Helena, Miguel, Raoni, Lillian, Manoel, Fábio, João, Val, Adriana, Jaque (gaúcha), Jaque (carioca), Andréia, Rodrigo, Márcio (BH), Márcio (SP), Silvia, Luiz, Regivaldo, Sarah, Ceará, Carol, Bruno, Natália, Carla, Teresa, Fábio (SP), Fabi, Luiza, Anna, Alzira, Emily, Leandro (Merrinha), Leandro (Iranduba), Jobson (Macunaíma), Dona Dina. Se esqueci de colocar algum nome, peço desculpas, mas sinta-se agradecido!

Sou eternamente agradecida à Eliana, Luiz e Kazuo, por nos darem um lugar para morar e, literalmente, nos adotarem, nos dando um apoio familiar, inesperado, em São Paulo.

Agradeço aos dois "W" que me ajudaram a "dar um jeito" nesse mestrado, Wesolowski e Wenceslau: a Verônica Wesolowski por sua paciência, ajuda, correções e 
orientação; ao Wenceslau Teixeira pela enorme quantidade de pistas, desafios e respostas que ele me lançou nos últimos meses.

Não posso deixar de agradecer Jaroslav Brüzek, que teve a paciência de me auxiliar no começo dessa empreitada, e a Sheila Mendonça de Souza. Ambos me passaram conhecimento e me ajudaram a podar as minhas loucas idéias, sem contar a enorme bibliografia que me ofereceram!!

Agradeço à Claúdia, ao Levy e à Patrícia, pois além de me socorrerem com as identificações, me ajudaram a formular várias idéias. A Sílvia, ao Luis e ao Regivaldo: aprendi muito com vocês, valeu pela força!

Agradeço a todo o pessoal do MAE/USP (biblioteca, seção acadêmica, reserva técnica, etc.), vocês sempre ajudaram e facilitaram as nossas vidas, particularmente a minha. Obrigada por estarem sempre disponíveis e serem tão atenciosos.

Agradeço: aos meus amigos, que não são muitos, mas estão sempre presentes; a Helena e o Jefferson que aguentaram o meu mau humor dos últimos tempos. A Myrtle, Marjorie, Francini, Nina e Adriana (Dri) um obrigada especial

Agradeço a todos que marcaram a minha vida, mas que agora já se foram, obrigada pelo carinho e pelos ensinamentos.

Agradeço a Fundação de Amparo à Pesquisa do Estado de São Paulo, ou a "mãe FAPESP”, que viabilizou a existência desse projeto e do PAC nesses últimos anos. 


\section{APRESENTAÇÃO DO MESTRADO}

O presente trabalho foi dividido em sete partes, que visam apresentar o desenvolvimento das pesquisas realizadas utilizando as bases teóricas da arqueologia da morte e da tafonomia. Primeiramente dentro de INTRODUÇÃO as pesquisas são contextualizadas dentro de um quadro mais amplo de arqueologia Amazônica, com exposição das hipóteses de trabalho e dos objetivos. Em seguida uma descrição detalhada é feita do SÍTIO HATAHARA, que vem sendo estudado há vários anos e para o qual há a possibilidade de estabelecer diálogo com várias pesquisas feitas sobre temas distintos, aqui também será apresentada a metodologia do PAC para esse sítio. Na parte de FUNDAMENTAÇÃO TEÓRICA: CONCEITOS SOBRE A ARQUEOLOGIA DA MORTE E A TAFONOMIA são apresentadas a fundamentação teórica da arqueologia da morte e da tafonomia, que determinaram os métodos e técnicas a serem utilizados. Em MÉTODOS foi descrito todos os procedimentos, relacionados à arqueologia da morte, adotados e as escolhas feitas de acordo com as especificidades locais. A seguir foram expostas em RESULTADOS as informações obtidas em campo e em laboratório a partir dos sepultamentos, que são o ponto de partida de todo esse estudo. Em DISCUSSÃO os resultados serão comparados e discutidos em vários níveis até chegar às hipóteses colocadas no começo do trabalho. Enfim na CONCLUSÃO tópicos com os resultados serão apresentados. 


\section{ÍNDICE GERAL}

ÍNDICE DE FIGURAS ... iii

RESUMO ... vii

ABSTRACT ...viii

1. INTRODUÇÃO ...1

1.1 O contexto no qual se desenvolveu essa pesquisa ...1

1.2 O Projeto Amazônia Central (PAC) ...2

1.3 Hipótese ...4

2. O SÍTIO HATAHARA ...7

2.1 O Sítio Hatahara: a luz das intervenções arqueológicas ...8

2.2 Ocupações ...24

2.3 Análises químicas do solo ...27

2.4 Fase Paredão ...28

3. FUNDAMENTAÇÃO TEÓRICA: CONCEITOS SOBRE A ARQUEOLOGIA DA MORTE E A TAFONOMIA ...30

3.1 A Arqueologia da Morte ...30

3.1.1 Origens da Arqueologia da Morte ...30

3.1.2 O que é a Arqueologia da morte? ...33

3.2 O que é a Tafonomia?...35

3.2.1 Definição ...35

3.2.2 Os objetivos ...37

3.2.3 Materiais e prática da tafonomia ...38

3.30 estudo de contextos funerários e a formulação de hipóteses: como a arqueologia da morte e a tafonomia trazem respostas sobre as populações do passado ...41 
4. MÉTODOS ...44

4.1 Metodologia aplicada à análise de sepultamentos em campo ...44

4.2 O laboratório ... 51

4.3 Metodologia aplicada à reconstituição do material ósseo ...54

4.4 Definições utilizadas ...55

5. RESULTADOS ...58

6. DISCUSSÃO ...102

6.1 Observações gerais sobre os sepultamentos ...102

6.2 Observações gerais sobre os processos tafonômicos ...107

6.3 Discutindo a hipótese inicial ...114

7. CONCLUSÕES ...116

8. BIBLIOGRAFIA ...119

9. ANEXOS ... 129

Anexo 1: Mapa do Sítio Hatahara. Parcialmente atualizado até 2008. Mapa realizado a partir de M.E.B. Castro 2006.

Anexo 2: Perfil Oeste da trincheira escavada até 2002. Flechas indicam presença de vestígios ósseos. Desenho adaptado de M.E.B. Castro.

Anexo 3: Perfil Oeste do Montículo III.

Anexo 4: Ficha de Desmontagem

Anexo 5: Planta baixa da distribuição dos sepultamentos no montículo I

Anexo 6: Profundidade dos sepultamentos escavados no montículo I 


\section{INDÍCE DE FIGURAS E TABELAS}

\section{FIGURAS}

Figura 1: Planta baixa da área onde as urnas Manapacuru foram encontradas. Arte Final M.E.B. Castro.

Figura 2: Perfil oeste da unidade N1148W1576. Feições visíveis no perfil. Setas indicam feições. Foto Jaqueline Gomes.

Figura 3: Cabecinha Paredão, aplique típico das urnas funerárias da fase Paredão. Foto de Wagner Souza e Silva.

Figura 4: onde há a cota da base do sepultamento, levou-se em conta somente o número de baixo (ex. 47,22m) que está relacionado ao DATUM do Sítio. Fonte: PAC.

Figura 5: Foto do Sepultamento I. Fonte: PAC. 58

Figura 6: Foto utilizada como croquis do Sepultamento I. Fonte: PAC.

Figura 7: O sepultamento III estava logo acima do sepultamento I. Os ossos encontrados 60 no sedimento podem pertencer de ambos. Fonte: PAC

Figura 8: Associação do sepultamento I, II e III. 1999. Fonte: PAC.

Figura 9: Sepultamento II. Fonte: PAC.

Figura 10: Sepultamento II, coberto por cerâmicas. Fonte: PAC.

Figura 11: Segunda fase de desmontagem do Sepultamento II.Fonte: PAC.

Figura 12: Foto do Sepultamento III. Fonte: PAC.

Figura 13: Detalhe do osso coxal do sepultamento III, superfície auricular de aspecto jovem.

Figura 14: Sepultamento IV. Foto: R. Bartolomucci.

Figura 15: Articulação supranumerária. Sepultamento IV. Foto: Wagner Souza e Silva.

Figura 16: Sepultamento V (setas brancas). Foto: R. Bartolomucci.

Figura 17: Foto dos sepultamentos IV, V e VI. A seta branca indica o número VI. Foto:

R. Bartolomucci.

Figura 18: Detalhe do sepultamento VI.

Figura 19: Detalhe do sepultamento em laboratório.

Figura 20: Foto do Sepultamento VII. Foto: R. Bartolomucci.

Figura 21: Sepultamento VII. Detalhe mandíbula e maxila.

Figura 22: Foto do sepultamento VIII. Foto: Claide Moraes.

Figura 23: Sepultamento VIII. Delimitação do espaço está presente. Grande 70 movimentação dos ossos. Foto: Claide Moraes. 
Figura 24: Fragmento de fauna com marca de cestaria encontrada no sepultamento XIII.

Foto: Myrtle Shock.

Figura 25: Fragmento de fauna com marca de cestaria encontrada no sepultamento XII.

Figura 26: Junção dos croquis do sepultamento IX e XII, mostrando que são um só.

Fonte: PAC.

Figura 27: Sepultamento IX. Fonte: PAC.

Figura 28: Croquis do sepultamento XII sendo feito. Muito perturbado. Fonte: PAC.

Figura 29: Sepultamento IX/XII. Detalhe da tíbia e fíbula esquerda.

Figura 30: Ossos do sepultamento XII, estado avançado de decomposição. Grande diferença com o material retirado em 2001.

Figura 31: Foto do Crânio em processo de escavação. Retirado em 2001.

Figura 32: Detalhe dos sepultamentos escavados em 2001. Seta indica sepultamento X.

Fonte: PAC.

Figura 33: Indivíduo B. Robusto do sepultamento X. Foto Val Moraes.

Figura 34: Depósito XI. Fonte: PAC.

Figura 35: Detalhe do depósito. Foto: Nina Hochreiter.

Figura 36: Foto do sepultamento XIII. Foto: R. Bartolomucci.

Figura 37: Detalhe sepultamento XIII. Pode-se ver relação anatômica entre várias partes. Foto: R. Bartolomucci.

Figura 38: Foto do Sepultamento XIV, setas indicam três crânios diferentes. Foto: Val 80 Moraes.

\begin{tabular}{|l|l}
\hline Figura 39: Foto do Sepultamento XV. Foto: Claide Moraes. & 81
\end{tabular}

\begin{tabular}{|l|l}
\hline Figura 40: Detalhe do depósito XV. & 81
\end{tabular}

\begin{tabular}{|l|l}
\hline Figura 41: Sepultamento XVI. & 82
\end{tabular}

\begin{tabular}{|l|l}
\hline Figura 42: Sepultamento XVI perto de bioturbação. & 83
\end{tabular}

\begin{tabular}{|l|l|}
\hline Figura 43: Detalhe da maxila. & 83
\end{tabular}

\begin{tabular}{|l|l}
\hline Figura 44: Foto do Sepultamento XVII. Foto: Val Moraes. & 84
\end{tabular}

\begin{tabular}{|l|l}
\hline Figura 45: Foto do depósito XVIII. & 85
\end{tabular}

\begin{tabular}{|l|l}
\hline Figura 46: Detalhe do depósito XVIII. & 85
\end{tabular}

\begin{tabular}{|l|l}
\hline Figura 47: Mancha amarela sobre o sepultamento XIX. & 86
\end{tabular}

\begin{tabular}{|l|l}
\hline Figura 48: Foto do sepultamento XIX. Foto: Val Moraes. & 86
\end{tabular}

\begin{tabular}{|l|l|}
\hline Figura 49: Detalhe das mãos do sepultamento XIX. & 86
\end{tabular} 


\begin{tabular}{|c|c|}
\hline Figura 50: Sepultamento XIX. Foto: Val Moraes. & 87 \\
\hline $\begin{array}{l}\text { Figura 51: Canino direito nasceu por cima de PM2 e soltou um pouco durante a limpeza } \\
\text { mas está no seu local. Foto: Claide Moraes. }\end{array}$ & 88 \\
\hline $\begin{array}{l}\text { Figura 52: seta preta indica canino e seta vermelha a perda ante-mortem. Foto: Claide } \\
\text { Moraes. }\end{array}$ & 88 \\
\hline Figura 53: Foto do Sepultamento XX. Foto: Val Moraes. & 89 \\
\hline Figura 54: Detalhe da mão. & 89 \\
\hline Figura 55: Foto do Sepultamento XXI. & 90 \\
\hline Figura 56: Metacarpo e falanges em conexão. Detalhe do sepultamento XXI. & 90 \\
\hline Figura 57: detalhe da mão do sepultamento XXI. & 90 \\
\hline Figura 58: Depósito XXII. & 91 \\
\hline Figura 59: Foto do Sepultamento XXIII. & 92 \\
\hline Figura 60: Detalhe do osso coxal do sepultamento XXIII. & 92 \\
\hline $\begin{array}{l}\text { Figura 61: seta vermelha mostra o local do sepultamento XXIII, a leste pode-se ver uma } \\
\text { feição. Foto :Val Moraes. }\end{array}$ & 93 \\
\hline $\begin{array}{l}\text { Figura 62: A seta indica o local do sepultamento XXIV, perto de várias feições. Foto: } \\
\text { Val Moraes. }\end{array}$ & 94 \\
\hline Figura 63: Foto do Sepultamento XXIVem bloco no laboratório. Foto: Val Moraes. & 94 \\
\hline $\begin{array}{l}\text { Figura 64: detalhe da coluna vertebral do indivíduo no sepultamento XXIV. Foto: Val } \\
\text { Moraes. }\end{array}$ & 95 \\
\hline Figura 65: Foto do Sepultamento XXV. Foto: Val Moraes. & 96 \\
\hline $\begin{array}{l}\text { Figura 66: Acima está o sepultamento XXV, enquanto que embaixo está o sepultamento } \\
\text { XXIV. }\end{array}$ & 96 \\
\hline Figura 67: Detalhe da mandíbula. Lado esquerdo mais desgastado que o direito. & 97 \\
\hline Figura 68: Sepultamento XXVI. Foto: Val Moraes. & 97 \\
\hline Figura 69: Sepultamento XXVI. Detalhe pé direito. & 98 \\
\hline Figura 70: Sepultamento XXVI. Detalhe das mãos. & 98 \\
\hline Figura 71: Sepultamento XXVI. Detalhe pé esquerdo. & 99 \\
\hline Figura 72: sepultamento VIII. Ossos longos ao norte e crânio ao sul. Foto: Val Moraes. & 100 \\
\hline $\begin{array}{l}\text { Figura 73: Sepultamento XXVIII (flecha verde) e feição } 43 \text { (flecha vermelha). Foto: Val } \\
\text { Moraes. }\end{array}$ & 101 \\
\hline
\end{tabular}




\section{TABELA}

Tabela 1: Datas obtidas para o Sítio Hatahara

Tabela 2: resumindo os processos a serem observados e seus significados

Tabela 3: Sepultamentos por tipo de enterramento, número de indivíduos e relação direta ou indireta. Em negrito são os sepultamentos com indivíduos infantis e os que são seguidos por um ponto de interrogação têm algum problema de identificação.

Tabela 4: Sepultamentos e depósitos relacionados a suas camadas e profundidades respectivas.

As fotos não creditadas são da autora. 
RESUMO

O sítio Hatahara, município de Iranduba/AM, vem sendo estudado desde 1999 e já foi alvo de diversos trabalhos acadêmicos (Machado, 2005; Neves e Petersen, 2006; Tamanaha, 2006; Rebellato, 2007; Lima, 2008 e outros). Esse sítio é excepcional por diversas razões: tamanho, conteúdo, número de ocupações, montículos construídos e principalmente estado de conservação do material orgânico (humano, animal e vegetal).

Nesse trabalho optou-se por fazer uma análise mais aprofundada dos sepultamentos pertencentes à fase Paredão (séculos VII a XII) oriundos desse sítio. O objetivo sendo o de obter mais informações sobre as escolhas das comunidades pretéritas, os gestos funerários e o contexto no qual eles se inseriam. Os dados adquiridos através da perspectiva da arqueologia da morte e pela tafonomia estão sendo comparados aos trabalhos já produzidos sobre esse local.

Como resultado percebe-se um padrão funerário complexo com variações significativas e estruturas polivalentes (funerárias e habitacionais). Além disso, percebeu-se que a conservação dos materiais orgânicos estão intimamente relacionados a certas variáveis ambientais e culturais que permitem envisajar que mais sítios arqueológicosnessas condições possam ser descobertos na Amazônia.

Palavras-chaves: arqueologia da morte, sepultamentos, fase Paredão, Amazônia Central, tafonomia 


\section{ABSTRACT}

The Hatahara site, in Iranduba, State of Amazonas, has been studied since 1999 and was at the heart of many papers (Machado, 2005; Neves e Petersen, 2006; Tamanaha, 2006; Rebellato, 2007; Lima, 2008 and others). This site is exceptional for several raisons: size, content, number of occupations, earth mounds and mainly state of conservation of organic material (human, animal and vegetal).

For this project it was decided that a more thorough analyses should be conducted on the burials belonging to the Paredão phase $\left(7^{\text {th }}\right.$ to $13^{\text {th }}$ century) found in this site. The main purpose was to obtain information on the life of past societies, funerary rituals and the context in which they were inserted. The data acquired through the perspective of the archaeology of death and taphonomy are being compared to the work already produced about this site.

As a result we noticed a complex funerary pattern with meaningful variations and multi-purpose structures (funerary and habitation). Furthermore, it was observed that the preservation of organic materials was closely related to certain environmental and cultural variables that allow us to expect that more archaeological sites having these conditions may be discovered.

Key-words: archaeology of death, burials, Paredão phase, Central Amazon, taphonomy 


\section{INTRODUÇÃO}

Em 2006 foi apresentado um projeto de mestrado, para o Museu de Arqueologia e Etnologia/USP, sobre a arqueologia da morte na Amazônia Central durante a fase ${ }^{1}$ Paredão. Com o avançar do trabalho os esforços foram centrados nos sepultamentos da fase Paredão oriundos do sítio Hatahara (AM-IR-13).

\subsection{O contexto no qual se desenvolveu essa pesquisa}

Apesar de desde o meio do século XIX haverem relatos mencionando os vestígios das populações antigas da Amazônia, somente a partir de 1948 é que começaram as pesquisas profissionais na região com o casal de americanos, Betty J. Meggers e Clifford Evans. O objetivo de suas pesquisas era testar as hipóteses de ocupação levantadas por Julian Steward (1948) e Robert Lowie (1948) no Handbook of South American Indians. De acordo com esses autores existiriam quatro grandes categorias evolutivas e classificatórias para as populações tradicionais do continente sul americano baseadas no nível de complexidade cultural atingido. Essas categorias foram criadas a partir de observações etnográficas sobre as populações indígenas atuais. A classificação foi determinada pelo nível cultural das populações, mas também pelo meio ambiente que ocupavam, pois este determinaria, de acordo com os autores, a capacidade de uma sociedade de se desenvolver.

Os níveis de sociedades existentes na América do Sul seriam:

- O marginal: grupos de caçadores-coletores-pescadores composto de poucos indivíduos vivendo exclusivamente dos recursos mais próximos. Seriam sociedades igualitárias nômades ou seminômades habitando as margens da floresta tropical;

- A cultura de floresta tropical: populações com agricultura incipiente ou de coivara, mas sem regularidade. Compostas por pequenos grupos, com uma organização social igualitária, mesmo se todos os indivíduos não eram

\footnotetext{
${ }^{1}$ Durante todo o texto utilizamos a definição de fase adotada pelo PAC, onde ela corresponde a um instrumento cronológico com características próprias para manufatura de artefatos e ocupação do território, e não está diretamente relacionada a grupos étnicos ou populações específicas.
} 
necessariamente tratados do mesmo jeito e, com períodos de nomadismo. Habitaram a área de floresta tropical;

- Os cacicados do circum-caribe (em contato com sociedades da Mesoamérica e andinas): caracterizadas por uma organização complexa, com verdadeiros chefes, profissionais religiosos e, grandes assentamentos;

- Civilizações Andinas: impérios complexos com administrações centralizadas. Somente sociedades nos Andes teriam alcançado esse nível.

A partir do material recolhido no Baixo Rio Amazonas Meggers e Evans (1957) concluíram que todos os vestígios encontrados por eles na Amazônia pertenceriam às duas primeiras categorias. Colocado de outro modo as populações que habitaram a Amazônia não teriam conseguido "dominar” o seu meio ambiente o suficiente para evoluir em sociedades complexas.

Após esse primeiro período de pesquisas, o arqueólogo Donald Lathrap de certo modo inverte a visão que se fazia da Amazônia e ao invés de enxergá-la como um "inferno verde" a considerou um paraíso. Seguindo uma linha teórica parecida com a de Meggers (o difusionismo), mas influenciado por Carl Sauer, ele propos que a várzea amazônica seria o local ideal para o desenvolvimento cultural e a domesticação de plantas. (Lathrap, 1970; Neves, 1998). Para ele a maior parte das grandes “inovações” (como o aparecimento da cerâmica policroma) teria surgido na Amazônia Central (confluência dos Amazonas, Negro e Madeira), que teria funcionado como um coração enviando “cultura” para todas as direções (Lathrap, 1977).

\subsection{O Projeto Amazônia Central (PAC $\left.{ }^{2}\right)$}

As hipóteses de Lathrap foram elaboradas sem dados empíricos. Algumas décadas depois nasceu o Projeto Amazônia Central (PAC), criado em 1995, por Eduardo Góes Neves, James Petersen e Michael Heckenberger, que visava testar as hipóteses antagônicas de Lathrap e Meggers em uma região específica, o que

\footnotetext{
${ }^{2}$ O PAC é financiado pela Fundação de Amparo a Pesquisa do Estado de São Paulo (FAPESP) (processos 99/02150-0 e 02/02953-0) e, em 2005 foi aceito como projeto temático pela mesma instituição (05/60603-4), tendo assim certeza de continuação durante vários anos. Esse projeto também contou com o auxílio de uma bolsa FAPESP (processo 2007/52453-8).
} 
permitiria compreender a ocupação nesse local e ao mesmo tempo sua relação com toda a Amazônia (Neves et al., 2003).

Foi durante uma etapa de campo desse projeto que o Sítio Hatahara foi descoberto. Esse achado por si só já teve um peso significativo para a arqueologia da Amazônia Central (Neves e Petersen, 2006; Neves et al., 2003). Pois, a sua localização e o seu tamanho associados à enorme quantidade de material arqueológico (cerâmicas, montículos, sepultamentos, urnas, etc.) fazem dele um ótimo local de pesquisa para que várias questões diferentes sejam abordadas (Machado, 2005; Neves et al., 2003). Por exemplo, em 2005, Machado apresentou a hipótese de que o sítio corresponderia a uma ocupação organizada como cacicados, o que corroboraria com as hipóteses de Lathrap de grandes ocupações na região, ainda que as cerâmicas mais antigas da região não tenham sido encontradas nessa área.

Além disso, as particularidades de conservação desse sítio são únicas. Em primeiro lugar porque ali foram descobertos vários sepultamentos, algo incomum na arqueologia da Amazônia Central e também porque a conservação do material raramente permite que os vestígios humanos diretos - ossos - sejam analisados. Assim, até o presente momento, o sítio Hatahara foi o único sítio a céu aberto na Amazônia Central que pôde ser abordado através da perspectiva da arqueologia da morte, da forma como ela é proposta nesse trabalho. Essa sub-disciplina da arqueologia será utilizada para adquirir informações sobre os indivíduos sepultados no local auxiliando a completar o conhecimento sobre as ocupações na Amazônia Central e, possivelmente, sobre as ocupações da Amazônia como um todo.

A pesquisa apresentada aqui faz parte do PAC, que conta com uma equipe grande, multidisciplinar e multinacional. Sua área de atuação até o presente momento foi principalmente a confuência dos Rios Negros, Solimões e o rio Ariaú (furo que conecta os dois rios antes da foz). A área está a oeste de Manaus, compreendendo todo o município de Iranduba, no estado do Amazonas (Neves et al, 2003; Neves et al., 2007; Neves et al., 2009).

As contribuições do PAC para o conhecimento da arqueologia local e as ocupações humanas da região são fundamentais. (Costa, 2004, 2009; Machado, 2002, 2005; Moraes, 2003, 2006; Neves, 2000, 2001; Neves et al. 2003; Neves, Petersen, Bartone, da Silva, 2003; Petersen, Neves, Woods, 2005; Petersen, Neves, Heckenberger, 2001; Lima, 2004, 2008, entre outros). 
Para esse trabalho utilizaremos os dados recolhidos pelo PAC entre os anos de 1999 a 2008.

\subsection{Hipótese}

A partir do material de estudo escolhido, sepultamentos escavados em montículos, formulou-se hipóteses relacionadas ao contexto, à conservação e ao padrão funerário. Inicialmente definiu-se como pressuposto que os sepultamentos encontrados nos montículos do sítio Hatahara corresponderiam a um cemitério da fase Paredão. A partir desse pressuposto, definiram-se dois corolários:

- que essas estruturas construídas seriam responsáveis por toda ou parte da conservação do material ósseo;

- e que a diversidade funerária estaria relacionada ao status dos indivíduos falecidos.

Várias perguntas surgiram sobre a relação entre sepultamento e montículos:

- Os sepultamentos estariam relacionados aos montículos, que seriam estruturas exclusivamente funerárias?

A mesma geração, ou gerações próximas de uma mesma população, que ainda se lembrasse do local de enterramento dos antepassados, mas que por falta de marcador externo ou por decomposição desse último não se lembrasse de suas localizações exatas, utilizaria a mesma área para enterrar?

Essa população teria aproveitado para manter o mesmo local como cemitério após a construção do montículo, perturbando os sepultamentos pelo remeximento de terra ligado a atividades de enterramento (humano ou de feições)?;

Os montículos seriam construídos como piso de habitação e os sepultamentos corresponderiam aos indivíduos de uma família ou grupo social que morreram?

A construção dos montículos teria se dado em local já habitado - e com enterramentos já presentes - mas os habitantes teriam decidido elevar o seu piso de moradia?

Os sepultamentos mais antigos teriam sido perturbados durante o processo de construção? Algumas comunidades indígenas do Rio Uaupés eram conhecidas por enterrar seus mortos abaixo do piso de habitação, sem marcador externo (Silva, 1977). Enquanto que alguns montículos em Iranduba são conhecidos como estruturas 
domésticas;

Um novo grupo, ainda associado à fase Paredão, que teria construído montículos em cima dos locais que já eram habitados?

Assim, eles teriam perturbado os sepultamentos mais antigos durante a construção dos montículos e continuado a utilizar o local como cemitério, por acaso ou intencionalmente?

Para responder a estas perguntas e testar as hipóteses formuladas houve necessidade de saber qual a relação entre os montículos e os sepultamentos. Para isso, definiram-se como objetivos:

- Compreender os processos de conservação desses sepultamentos;

- Identificar os gestos funerários que possam estar relacionados a particularidades das populações pretéritas;

- Obter um panorama cronológico dos gestos funerários dentro da fase Paredão, a qual durou aproximadamente sete séculos. Isso é essencial para uma melhor compreensão das evoluções e mudanças culturais através dos tempos;

- Compreender a relação dos sepultamentos com os montículos no sítio Hatahara (único com sepultamentos) e como eles se diferenciam dos outros sítios com montículos na região;

- Conhecer quais e como os processos tafonômicos afetaram os sepultamentos. Com o reconhecimento desses processos visa-se diferenciar os gestos culturais dos processos naturais e como o processo de ocupação participa da evolução desses sepultamentos.

Além de entender os gestos funerários em si, procura-se, através do contexto arqueológico e das análises dos vestígios ósseos, obter uma janela sobre as ações e as populações vivas da época.

Outra questão importante sobre sítio Hatahara é a presença de mais de uma zona de concentração de sepultamentos, dentro e fora de montículos. Entretanto, as fases às quais esses contextos estão associados são diferentes. Os sepultamentos em montículos são associados à fase Paredão (exceto o sepultamento I que está em urna e que deve pertencer a uma fase mais antiga), enquanto que as urnas foram identificadas como pertencentes a uma fase mais antiga - Manacapuru (Lima, 2008). Outro tema 
relacionado que será foco de investigação é a questão de uma continuidade entre essas fases arqueológicas, o que já fora percebido pelas análises cerâmicas (Lima, 2008; Moraes, 2006), e que volta em pauta com a análise desse sítio e de seus sepultamentos. A utilização do material oriundo do sítio Hatahara permite uma comparação tanto sincrônica (material de outros sítios da fase Paredão) quanto diacrônica (material das fases antes e depois da fase Paredão).

Visto o grau de conservação do material orgânico, é possível trabalhar os sepultamentos através das perspectivas propostas pela a arqueologia da morte. Assim, serão analisados 28 concentrações ósseas (sepultamentos e depósitos) com aproximadamente 38 indivíduos, pertencentes à fase Paredão.

Todo esse conjunto de temas e de questionamentos teve que ser abordado para que questões mais amplas ligadas às escolhas culturais das populações antigas pudessem ser investigadas.

Um objetivo secundário, mas que no decorrer do trabalho ganhou bastante importância, foi a definição dos conceitos de arqueologia da morte e tafonomia e suas aplicações práticas. A apropriação desses conceitos causou reflexões sobre as definições apresentadas por diferentes autores e como elas estavam vinculadas a trabalhos específicos e, portanto, deveriam ser adaptadas aos contextos de análise. 


\section{O SÍTIO HATAHARA}

O sítio Hatahara foi descoberto em 1997 situado na margem esquerda do Rio Solimões sobre um terraço elevado (coordenadas: 3¹6’29”S 60¹2'16”W SAD 69) (anexo 1- Mapa do Sítio Hatahara). O local foi impactado por ocupações coloniais e recentes (áreas de pasto, cultivo de banana, mandioca, mamão, mangueiras e construções), entretanto seu grau de integridade continua muito bom, principalmente nas camadas mais profundas. Vários fatores fizeram com que esse sítio desde sua descoberta, despertasse grande interesse, pois remetiam às discussões citadas acima sobre o tipo de ocupação presente na Amazônia.

As características logo percebidas no sítio Hatahara foram: 1- grande quantidade de fragmentos cerâmicos na superfície; 2- presença de Terra Preta de Índio ${ }^{3}$; 3- posição geográfica, sem inundações, mas ainda perto dos recursos fluviais (Bluff Model de Denevan, 1996) (Machado, 2002, 2005; Neves et al., 2003; Tamanaha, 2006). A quantidade de fragmentos cerâmicos e a extensão da Terra Preta sugerem ocupações densas, grandes e por longos períodos. A esses traços deve-se adicionar a localização do sítio, que de acordo com as hipóteses de Denevan (1996) mostra um aproveitamento mais organizado dos recursos (rio, várzea e terra firme), permitindo assentamentos maiores.

Depois do começo dos trabalhos no sítio, outras características foram identificadas (Machado, 2002, 2005; Neves et al., 2003; Rapp Py-Daniel, 2008; Tamanaha, 2006): a presença de montículos ${ }^{4}$; sepultamentos diversos datados de momentos distintos; complexidade da estratigrafia (longa e com inversões); presença de vestígios correspondendo a pelo menos quatro fases arqueológicas (Açutuba, Manacapuru, Paredão e Guarita); padrões diferentes de ocupação (aldeia circular e linear).

\footnotetext{
${ }^{3}$ Terra Preta de Índio, Terra Preta Antropogênica, Terra Preta Arqueológica ou Amazonian Dark Earths, “... constituem áreas que apresentam horizonte A antrópico...encontradas principalmente na Amazônia... Nas áreas de várzeas são encontrados os horizontes antrópicos comumente soterrados pela deposição de sedimentos das cheias dos rios... As cores escuras dos horizontes superficiais ocorrem em razão da elevada concentração de carbono total e elevada concentração de carbono de origem pirogênica" (Teixeira et al., 2009)

${ }^{4}$ Os montículos no sítio Hatahara foram definidos por Machado (2005: 67) como: morrotes artificiais, construídos com terra preta e cerâmica, chegando a alturas variadas.
} 
Em função de todas essas características o Sítio Hatahara apresenta um grande potencial para a investigação das sociedades que habitaram a área no passado. Por isso ele foi e continua sendo o objeto de estudo de diversos projetos acadêmicos com objetivos diferentes, dentro das perspectivas do PAC (Lima, 2008; Machado, 2005; Rebellato, 2007; Rapp Py-Daniel, 2008; Tamanaha, 2006).

\subsection{O Sítio Hatahara: a luz das intervenções arqueológicas}

A história do sítio Hatahara é longa e dinâmica, pois nele várias ocupações pré-coloniais ocorreram e, hoje esta área continua a ser habitada e recebe várias intervenções. Em função do caráter amostral da arqueologia e pelo sítio ser muito complicado e denso os estudos estão longe de desvendar toda a organização social e a história das ocupações pretéritas. O que se tem hoje são fragmentos sobre como viveram os antigos habitantes desse local. Vários tipos de intervenções foram realizados no sítio, e várias abordagens de análise vem sendo trabalhadas com diferentes materiais (sedimento, restos vegetais, formação de montículos, etc.) mas com um objetivo em comum: compreender os acontecimentos nesse local nos últimos 2000 anos (Machado, 2005; Neves et al., 2003; Rebellato, 2007; Tamanaha, 2006; Tamanaha e Rapp Py-Daniel, 2009).

Uma das características mais importantes do sítio Hatahara é a presença de montículos identificados durante o levantamento topográfico e delimitação do sítio. Até o momento a maior parte das intervenções realizadas está associada a essas estruturas (Machado, 2005; Neves et al., 2003).

\section{A delimitação do sítio e das estruturas monticulares}

A metodologia utilizada em campo foi definida pelo Projeto Amazônia Central ao longo dos anos (Machado, 2005; Neves et al., 2003; Rebellato, 2007). Alguns ajustes foram necessários de acordo com as pesquisas acadêmicas realizadas. Será apresentada aqui essa metodologia geral de maneira resumida, a metodologia relacionada às especificidades de escavação dos sepultamentos e a análise de processos tafonômicos estão descritas da parte de MÉTODOS. 


\section{$\underline{\text { O grid }}$}

Dentro do PAC foi definido para o sítio Hatahara um grid ou quadriculamento independente das coordenadas geográficas, mas amarrado a elas. Assim a área foi quadriculada seguindo um plano ortogonal, alinhado a um ângulo aproximado de $45^{\circ}$ leste em relação ao norte magnético. Por convenção determinou-se que todos os cantos noroestes da cada quadra de 1 x $1 \mathrm{~m}$ dariam o nome às sondagens, sejam elas tradagens ou unidades e, que os nomes seriam dados de metro em metro. Também está definido que o ponto N1000W1000 seria no meio do Rio Solimões de tal maneira a que não se utilizasse coordenadas negativas e evitando números quebrados com decimais. Sendo assim, todas as referências utilizadas nesse trabalho se relacionam a extremidade noroeste dos quadrantes de $1 \mathrm{~m}$ por $1 \mathrm{~m}$, mesmo que todo o quadrante não tenha sido escavado (Machado, 2005; Neves et al., 2003).

\section{Delimitação do sítio e das estruturas}

O procedimento de delimitação do sítio Hatahara entre os anos de 1999 e 2002 se fez por tradagens (ver mapa com perfil das tradagens) e se concentrou nas áreas abertas ou com vegetação baixa. Através dessas tradagens percebeu-se quais eram as áreas com maior quantidade de vestígios (cerâmica e terra preta) e com maior potencial (local de urnas funerárias). Em 2009, um trabalho de resgate pontual realizado do canto nordeste do sítio, mostrou que o sítio se estendia para áreas com pouca terra preta.

Outras séries de tradagens foram utilizadas para identificar possíveis estruturas e limites de montículos, essas linhas permitiram ter vários perfis das camadas estratigráficas do sítio. Entretanto, o depósito de material arqueológico vai além de 1m de profundidade, limite das tradagens com boca de lobo, na maior parte do sítio, portanto as camadas mais antigas não são detectadas.

\section{Unidades}

A decisão de abrir unidades (ou poço-teste) de escavação se deu por várias razões. Uma unidade tem por padrão um metro quadrado e a retirada de terra se faz por níveis artificiais de 10 em $10 \mathrm{~cm}$, para um melhor controle horizontal, podendo ser expandida dependendo do tamanho julgado necessário para compreensão do contexto 
de escavação. Essas unidades têm várias funções: amostragem; exploração, reconhecimento do contexto e controle das camadas de deposição.

Por convenção a profundidade das unidades está relacionada à presença de vestígios arqueológicos mais dois níveis estéreis. No caso de áreas mais amplas ou de contextos muito perturbados, houveram exceções.

No caso de escavações mais amplas com várias unidades de $1 \mathrm{~m}^{2}$ contínuas, toda a região escavada foi exposta concomitantemente para que os contextos e as relações entre vestígios fossem mais bem observadas.

\section{$\underline{\text { Estratigrafia }}$}

A sobreposição das diversas camadas arqueológicas no sítio foi analisada a partir das tradagens, mas principalmente através das unidades, onde estas puderam ser vistas em toda sua profundidade e com mais precisão. A identificação de camadas se fez pelas mudanças de cor, textura, quantidade e distribuição de materiais arqueológicos.

\section{Características do sítio}

O sítio Hatahara como um todo (sem diferenciar as ocupações) ocupa uma área aproximada de $160.000 \mathrm{~m}^{2}$. Ao longo dos últimos dez anos foram identificados dentro desta área mais de 14 elevações monticulares (chegando a 1,5 m de altura) (Machado, 2005; Neves et al., 2003). De acordo com Machado (2005) estes montículos ocorrem em grupos e encontram-se em quatro conjuntos, sendo cada um destes conjuntos composto por quantidades diferentes de montículos. Considerando o eixo oeste-leste do sítio, cada conjunto apresenta a seguinte composição quanto ao número de montículos: 2, 4, 6 e 2 (ver anexo 1). Entretanto essa estruturação não está clara, pois durante a etapa de campo de 2008 mais um montículo foi encontrado a noroeste dos quatro conjuntos anteriormente definidos. Rebellato (2007) também apresenta os dois montículos a leste do sítio como sendo um só e de origem natural (ver anexo 1), devido à baixa densidade de material e às baixas concentrações de nutrientes do solo (enquanto que os outros montículos apresentam ambos os teores bem elevados).

A artificialidade dos montículos remete a várias questões sobre o tipo de sociedade que os construiu. De acordo com Machado (2005), esse tipo de estrutura 
estaria ligada a sociedades socialmente complexas, próximas ao que Steward (1948) e Lowie (1948) chamaram de cacicados - ver INTRODUÇÃO. A mobilização de mãode-obra necessária para a construção associada ao grande porte do sítio seriam indicações desse tipo de organização (ver Machado, 2005, para uma discussão mais elaborada sobre sociedades complexas a partir desses dados).

Através das escavações foi possível identificar que essas estruturas são constituídas principalmente com terra preta de índio e com material cerâmico fragmentado, que por vezes chega a ser mais abundante que a própria terra (Machado, 2005; Tamanaha, 2006). Nos montículos as tradagens eram normalmente acompanhadas de terra preta até a base, e nas demais áreas do sítio a camada de terra preta variou entre $20 \mathrm{~cm}$ e $60 \mathrm{~cm}$ (Machado, 2005). Estudos sobre os montículos do município de Iranduba (Moraes, 2006), análises de solo do sítio Hatahara (Rebellato, 2007) e estratigrafia indicam que essas estruturam foram construídas durante a fase Paredão (Tamanaha e Rapp Py-Daniel, 2009).

\section{O Montículo I}

O montículo mais alto e extenso, denominado de M.I, no centro do sítio, foi escolhido para uma primeira sondagem em 1999 e nele se concentraram a maior parte das intervenções no sítio Hatahara. Nestas escavações foram encontrados uma urna funerária e outros dois sepultamentos diretos, além disso, percebeu-se que o contexto arqueológico continuava abaixo da terra preta (Machado, 2005; Neves et al., 2003).

Esse montículo contém uma altíssima densidade de material cerâmico e faunístico, além de apresentar sepultamentos primários, secundários, estruturas de combustão, feições bem definidas e dois "pisos" de construção em cerâmica (concentrações importantes com fragmentos horizontais que formam a camada de construção, ver Machado, 2005).

Em 2001 encontrou-se dez sepultamentos. No ano seguinte abriu-se no mesmo montículo uma trincheira de $6 \mathrm{~m}$ de comprimento por $1 \mathrm{~m}$ de largura para ligar as áreas de escavação de 1999 e 2001 e compreender o que começava a se apresentar como um contexto funerário complexo. Entretanto, foram encontrados poucos vestígios humanos, comparado com as duas áreas abertas anteriormente, mas o perfil de escavação obtido permitiu compreender a formação da camada monticular com maior precisão (ver anexo 2). Adicionado a isso também foram encontradas várias 
feições, algumas em terra preta, outras começando no solo mosqueado e, finalmente, algumas que pareciam estar exclusivamente em solo amarelo. Em alguns pontos, material cerâmico foi obtido até $250 \mathrm{~cm}$ de profundidade.

No ano de 2006 foram abertos $12 \mathrm{~m}^{2}$ em uma só etapa, percebeu-se certa estabilidade das camadas do montículo, que não mostraram muita variação mesmo três metros mais a leste do perfil anteriormente desenhado (ver anexo 2). Diferentemente dos anos precedentes, os sepultamentos encontrados no M.I estavam enterrados em menor profundidade. Os sepultamentos começaram a aparecer no nível 70-80cm, na periferia da área aberta. Enquanto que, os sepultamentos concentrados nas duas extremidades da trincheira abertas entre 1999 e 2001 começavam aos $90 \mathrm{~cm}$, sendo que a maior parte estava a mais de um metro de profundidade (Machado, 2005). Essa diferença de profundidade, junto às analises estratigráficas em campo, levou a uma reavaliação do posicionamento dos sepultamentos dentro das camadas definidas anteriormente. Será abordado mais amplamente a localização dos sepultamentos na parte de RESULTADOS deste trabalho.

Outra diferença em relação às escavações anteriores foi a ausência, na maioria das vezes, de material lítico ou vasilhas associadas aos sepultamentos. Em compensação, vários fragmentos de cerâmica da fase Paredão continuavam relacionados aos sepultamentos. Uma grande variedade de enterramentos e depósitos foi encontrada. Além disso, perturbações, humanas na sua maioria, ligadas a ocupações mais recentes foram identificadas e parecem ser responsáveis pela grande dispersão de restos humanos encontrados.

Durante a escavação do M.I feições em forma de bacia, com grande densidade de cerâmica, foram encontradas (Neves et al., 2007; Rapp Py-Daniel, 2008). As cerâmicas ainda não foram analisadas, mas várias dessas feições parecem ser da fase Paredão. A construção dessas feições teria perturbado níveis mais antigos de ocupação das fases Manacapuru e talvez Açutuba misturando as cerâmicas ao redor. No total aproximadamente $22,25 \mathrm{~m}^{2}$ foram abertos.

O perfil estratigráfico desse montículo pode ser dividido em cinco grandes camadas, dentre as quais algumas podem ser subdivididas. A camada I consiste no latossolo amarelo, solo geológico, arqueologicamente estéril, cor 10YR 6/8 (brownish yellow). 
A camada II, situada entre 230 a $180 \mathrm{~cm}$ de profundidade, é caracterizada pela mistura de terra preta antropogênica e latossolo amarelo (cores 10YR 3/2 very dark grayish brown e 10YR 6/8 brownish yellow respectivamente), possuindo poucos fragmentos cerâmicos relacionados às fases Manacapuru e Açutuba (ver Meggers e Evans, 1961, Hilbert, 1968 e Lima et al. 2006 para definições da fase; ver Neves et al., 2003 e Machado, 2005 para descrição do sítio).

Na camada III, entre os níveis 180-110cm de profundidade (cor 10YR 2/1 black), vemos uma presença média de cerâmica associada à fase Paredão, com feições compostas por abundantes restos de fauna e carvão (ver Meggers e Evans, 1961 e Hilbert, 1968 para definições da fase; ver Neves et al., 2003 e Machado, 2005 para descrição do sítio). Nessa camada se encontram vários sepultamentos humanos.

Na camada IV (cor 10 YR 2/1 black), entre os níveis 110cm e 50cm, uma grande quantidade de fragmentos estava disposta na posição horizontal. De acordo com Machado (2005) essa camada pode ser dividida em três subcamadas paralelas (IVa, IVb e IVc), que constituem o montículo artificial. Nela muitos fragmentos cerâmicos grandes não remontáveis foram encontrados formando um “piso" (Machado, 2005) ${ }^{5}$. Aqui também estão presentes mais sepultamentos, aparentemente da fase Paredão e, mais próximo à superfície, cerâmicas da fase Guarita.

Por fim, a camada V (cor 10YR 2/1 black), que vai dos 50cm até a superfície, apresenta um pacote de terra preta antropogênica com fragmentos cerâmicos associados à fase Guarita, majoritariamente, e da fase Paredão, possuindo poucos vestígios da fase Manacapuru (Neves et al., 2003; Machado, 2005). A camada V também está muito perturbada por material recente, mas de fácil identificação (papel alumínio, ponta de cigarro, plástico, covas de bananeiras, etc.).

\footnotetext{
${ }^{5}$ Em 2006 o “piso” identificado por Machado (2005) não apareceu de forma contínua, apareceu muito perturbado, e cortado por várias feições.Somente quando a escavação ultrapassava o "piso”, e que a cerâmica continuava concentrada, ou que o perfil da feição se desenhava no perfil da escavação, é que podíamos ter certeza da sua existência (Neves et al., 2007; Rapp Py-Daniel, 2008, 2009; Tamanaha e Rapp Py-Daniel, 2009). Por exemplo, o “piso” fora identificado inicialmente como feição 17, que surgiu primeiramente na quadra N1158W1358, no nível 90-100cm. Em seguida percebemos que esta se ramificava de maneira clara para as quadras N1158W1357, N1157W1358 e N1157W1357, no nível $100-110 \mathrm{~cm}$. É possível que a feição identificada como F22 na quadra N1160W1359, no nível 90$100 \mathrm{~cm}$, também possa fazer parte desse piso, embora muito perturbada. Mas entre essas quadras não há evidências de "piso", mas a concentração de cerâmica continua grande. Assim esses "pisos” são uma grande concentração de cerâmica de maneira aleatória, mas intencional para estabilizar a construção, por isso não tem um local preciso, pensamos que essa definição corresponde à de Machado (2005).
} 


\section{$\underline{\text { O Montículo II }}$}

No M. II, no extremo leste do sítio Hatahara, foram escavados $3 \mathrm{~m}^{2}$ contínuos em "L" durante uma etapa de campo em 2001. Apesar de ter uma estrutura parecida em muitos pontos com o M.I, nele não há presença de cerâmica Guarita ou sepultamentos. Vale ressaltar que a área escavada não foi muito grande e que há possibilidade de ocorrerem sepultamentos.

Como no M.I. a profundidade de material arqueológico chega até aos $250 \mathrm{~cm}$ e cinco camadas puderam ser identificadas (Machado, 2005; Tamanaha, 2006). A camada I é o latossolo amarelo (10 YR 6/8 yellowish brown) arqueologicamente estéril, característico dessa região, e começa aproximadamente aos 2,50 m de profundidade.

Acima temos a camada II, entre 1,70 e 2,50m de profundidade, onde não há vestígios diretos de produção cerâmica, porém a presença humana é inferida pelos vestígios de terra escura, a cor $10 \mathrm{YR}$ 4/2 (dark grayish brown) é predominante (Machado, 2005; Tamanaha, 2006).

Entre 1,70 - 1,50 m (indo até 2,30 m em alguns pontos) encontra-se a camada III nota-se a presença de fragmentos cerâmicos associados, em menor escala à fase Manacapuru, e a fase Paredão (Tamanaha, 2006). Porém, a quantidade de carvão e fauna é maior em relação à camada superior e possivelmente podem estar ligados a uma fogueira (Machado, 2005; Tamanaha, 2006). A cor dessa camada varia, as tonalidades principais são 10YR 3/2 (very dark grayish brown) e 10 YR 6/8 (yellowish brown) na parte inferior enquanto que na parte superior ela varia entre 10YR 3/2 (very dark grayish brown) e 10YR 2/1 (black) (Machado, 2005).

A camada IV foi dividida em campo em duas subcamadas: IVA, indo de 80 a $150 \mathrm{~cm}$; e IVB entre 30 e $80 \mathrm{~cm}$. A separação em subcamadas ocorreu em função da densidade de cerâmica e disposição dos fragmentos, sendo a camada IVB a menos densa, (Machado, 2005), ambas correspondendo à estrutura do montículo. Nesses níveis encontramos uma maior quantidade de material cerâmico associado à fase Paredão, carvão e vestígios de fauna, em sua maioria de animais aquáticos, sendo alguns desses identificados como ossos de Pirarucu (Arapaima gigas) (Farias, 2006).

Entre a superfície e os $30 \mathrm{~cm}$ de profundidade está a camada V. No nível mais superficial, encontra-se muito carvão e pouca presença de cerâmica associada à fase Paredão, em comparação com as camadas correspondentes à construção do montículo 
(Tamanaha, 2006). A Terra Preta Antropogênica (10YR 2/1 black) continua presente (Machado, 2005).

A escavação desse montículo confirmou que os montículos eram artificiais e que o processo de construção era homogêneo. Além disso, o fato de não haver cerâmicas da fase Guarita sobre o montículo associado aos resultados dos trabalhos de Arroyo-Kalin (2008), Tamanaha (2006), Tamanaha e Rapp Py-Daniel (2009) e a etapa de campo de 2006, permitiram determinar as populações da fase Paredão como construtores desses montículos.

\section{O Montículo III}

Em 2008 foram abertos cinco metros quadrados no montículo III (M.III), que está oposto ao montículo I se considerarmos o agrupamento determinado por Machado (2005) (ver anexo 1). As escavações de 2008 vieram fortalecer a hipótese de que os montículos são Paredão, vale a pena mencionar que os métodos de datação não são confiáveis, visto que há muito remeximento de terra e inversão de material arqueológico (Machado, 2005).

Esse montículo está próximo de áreas menos densas em quantidade de vestígios arqueológicos, em direção norte do grid (ou quadriculamento), próximo a uma depressão. Entretanto, verificou-se que ele foi densamente ocupado. Apesar de o montículo ser de acesso fácil, ele estava pouco perturbado pelas ocupações mais recentes tendo, portanto, a estratigrafia mais integra - do que o montículo III - o que permitiu identificar que os processos de construção ocorridos nos montículos se assemelham (Neves et al., 2009).

Primeiramente duas unidades foram abertas nomeadas de N1308W1298 e N1309W1298, no decorrer da escavação decidimos abrir mais duas unidades de 1x1m em direção sul e contiguas às primeiras. Isso se deu porque se percebeu a preservação do contexto arqueológico, melhor que no M.I. Além disso, foram abertas mais uma área de 10x30cm no quadrante NE da quadra N1308W1297 e outra no quadrante SE de 40x30cm na quadra N1309W1297 para retirar o sepultamento XXVII, encontrado no nível $120 \mathrm{~cm}$.

Além dessa pequena trincheira outra unidade foi aberta no M.III, na verdade ela é a soma de duas meias quadras de $1 \mathrm{~m}^{2}$, a metade sul da quadra N1301W1295 e a metade norte de N1300W1295. Essas unidades foram abertas porque durante a 
realização da última tradagem de uma das linhas entre o M.III e o M.I, havia evidência sugestiva da existência de um vaso inteiro. Entretanto, ao descermos percebemos que não havia um vaso, pelo menos não no exato local da tradagem, mas havia uma enorme quantidade de material cerâmico, com fragmentos muito grandes e feições complexas (Neves et al., 2009).

Uma camada de nivelamento do solo feita com cerâmica foi identificada, essa camada pode se assemelhar ao que Machado (2005) chamou de "pisos" de construção, pois a cerâmica serviu para nivelar a antiga superfície. Entretanto, quando o material foi pesado verificou-se que há uma continuidade em peso, que os perfis não conseguem traduzir (Neves et al., 2009) (ver anexo 3).

Descobriu-se um pequeno vaso inteiro (diâmetro aproximado de $20 \mathrm{~cm}$ ) da fase Açutuba a aproximadamente 2m de profundidade na unidade N1300W1295.

A seguir vamos descrever as camadas encontradas no montículo seguindo o perfil oeste de N1309W1298. As camadas descritas seguem um padrão repetido em todas as unidades abertas nesse montículo, havendo poucas variações de profundidade. Como nos outros montículos do sítio temos um total de cinco camadas. A camada I (cor 10YR 5/6 yellowish brown) é estéril, com pouco sedimento percolado, ela é o latossolo, que começa a partir de $245 \mathrm{~cm}$ de profundidade.

A camada II (cor 10 YR 6/6 brownish yellow) é composta por um sedimento heterogêneo com muita percolação. Ela é uma camada de transição com pouco material arqueológico situada entre 195 e 265cm. Fragmentos de cerâmica e feições da fase Açutuba estão presentes.

Na camada III, entre 110 e 195cm, a coloração varia entre: 10YR3/2 (very dark grayish brown), 10YR3/3 (dark brown) e 10YR3/4 (dark yellowish brown). Os fragmentos cerâmicos encontrados eram pequenos e pertencentes a fase Manacapuru. O sepultamento XXVII estava no nível $120-130 \mathrm{~cm}$, entretanto é possível que ao realizar a sua cova tenham enterrado ele abaixo do nível de habitação.

A camada número IV (cor 10YR 2/1 black), é a camada monticular propriamente dita, com grandes fragmentos cerâmicos, bases e paredes de vasos grandes. Como mencionado mais acima não foi possível delimitar pisos, pois a quantidade de cerâmica é praticamente a mesma entre 5 e $110 \mathrm{~cm}$.

A camada V (cor 10YR 2/2 very dark brown) é a mais superficial. O sedimento estava bastante compactado com a presença de pequenos fragmentos de 
cerâmica e muitas raízes. Essa camada ia da superfície até 5 ou $25 \mathrm{~cm}$ dependendo da localização.

\section{O Montículo IV}

Ao abrir esse local, não se tinha certeza sobre a presença de um montículo, o relevo do local não se diferenciava o suficiente dos arredores, mas nas tradagens feitas nos anos anteriores esse local foi identificado por uma maior quantidade de terra preta. Quando atestado o montículo foi chamado de IV (M.IV). Rebellato (2007) chamou esse local de "montículo multifuncional”, pois apresenta:

- “elevados teores de potássio (K), magnésio (Mg) e cálcio (Ca) .... Tais nutrientes têm seus níveis aumentados, entre outras coisas, devido a cinzas de figueiras $(\mathrm{K})$, dejetos vegetais $(\mathrm{Mg})$ presença de ossos (faunísticos ou humanos). Estas variações sugerem práticas distintas daquelas levadas a cabo em outros locais próximos aos montículos, principalmente em relação a presença de (K) e $\mathrm{Mg}$ ) (apresentando os teores mais elevados de todo o sítio) $e$, portanto, pode-se dizer que tal montículo apresenta características de múltiplas funções, dados os elevados teores encontrados em sua proximidade bem como a variedade de elementos nele constituídos.” (Rebellato, 2007: 66) Inicialmente uma unidade de $1 \mathrm{x} 1 \mathrm{~m}$ foi aberta no que parecia ser a parte mais alta, no meio de uma plantação de mamão, N1139W1541, ao chegar ao nível 100$110 \mathrm{~cm}$ encontrou-se uma concentração óssea aparentemente em conexão e possivelmente humana, e em função disso mais uma unidade teve que ser aberta na direção sul, N1138W1541. Entretanto ao chegarmos nesse possível sepultamento percebemos que a deterioração dos ossos estava em estado muito avançado, portanto fizemos uma retirada em bloco, a ser escavado e analisado em laboratório. Mesmo sem a certeza de que se tratava de um sepultamento, este foi nomeado como tal.

$\mathrm{Na}$ análise da área escavada não foi possível atestar a multifuncionalidade deste montículo, como propõe Rebellato (2007), devido à perturbação encontrada nas primeiras camadas. Estas estavam extremamente remexidas, com grande quantidade de material cerâmico muito fragmentado e apresentando conteúdo pouco homogêneo. Essa aparente desordem pode ser o resultado de funções diferentes (como propõe Rebellato, 2007), mas é também fruto da utilização do solo, mais recentemente, para plantação de mamão e outros vegetais. 
Para a apresentação das camadas usamos o perfil oeste de N1139W1541 como modelo. Salientamos que a estrutura monticular não é clara, a definição desse local como montículo se deu pela sua leve elevação; pela camada IV, com aumento significativo de cerâmicas; e pela profundidade da terra preta quando comparado às unidades de controle.

A primeira camada (I) (cor 10YR 6/8 brownish yellow) é o latossolo estéril, com solo muito compactado. A camada começa a partir de 160/180 cm de profundidade mas algumas feições a cortam até 386cm como é o caso da feição (F57) na quadra N1138W1541 que começou a ser identificada na base do nível 260-270cm. Nela não havia presença de material cerâmico, mas sua coloração escura com bordos retos paralelos indica um possível buraco de poste.

Na camada II (cor 10YR3/4 dark yellowish brown) o sedimento estava muito compactado, com pouco material cerâmico, mas com uma presença significativa de fragmentos faunísticos presentes. É uma camada de transição entre a terra preta e o latossolo, começando aos $135 \mathrm{~cm}$ e terminado aos 160/180 cm de profundidade.

A camada III (cor 10YR3/1 very dark gray) continua com o sedimento muito compactado. Os limites são muito difusos, aproximadamente entre 70 e $135 \mathrm{~cm}$. É perceptível um aumento claro na quantidade de carvões, cerâmica e trempe. O sepultamento XXVIII foi encontrado nessa camada no nível 100-110cm, mas não está claro se ele pertence realmente a ela ou se a cova impactou uma camada mais profunda.

A provável camada monticular IV (cor 10YR 2/2 very dark brown) contém uma grande quantidade de cerâmicas e de bioturbações. Nela não foi possível delimitar pisos ou concentrações claras de cerâmicas, o material estava muito remexido. Essa camada está entre 30 e 70cm de profundidade.

A camada V (cor 10YR 2/1 black) é a mais superficial, localizada entre 0 e $30 \mathrm{~cm}$. O sedimento foi extremamente remexido pelo plantio, fragmentos pequenos de cerâmica estão por cima de todo o montículo.

Os montículos escavados no Hatahara diferenciam-se de outros conhecidos na região tanto pelo tamanho como pela composição. No trabalho de Moraes (2006), foram apresentados montículos muito menores e com densidades de cerâmica muito inferiores às encontradas no sítio Hatahara. Na maior parte dos casos a interpretação 
desses montículos como locais de habitação é quase certa (presença de trempe, buracos de estaca e suas disposições) (Moraes, 2006). É interessante notar que todos os montículos apresentados no trabalho de Moraes (2006) são da fase Paredão, como os do Hatahara. Entretanto, em nenhum desses casos foram encontrados vestígios humanos diretos (sepultamentos, ossos ou urnas) até o presente.

Outros sítios na região de estudo também apresentam montículos da fase Paredão: Lago Grande (Donatti, 2002), Lago do Limão, Pilão, Antônio Galo (Moraes, 2006), Açutuba (Lima, 2005), Laguinho, Lago do Iranduba (Neves et al., 2007). Todos os montículos conhecidos na Amazônia central são da mesma época e, em vários casos, estão dispostos de forma mais ou menos circular, padrão similar aos montículos do Hatahara. Entretanto, poucos são aqueles que têm o tamanho e a concentração de vestígios dos montículos I e II do Hatahara, o que nos faz pensar que o sítio provavelmente tinha um status particular ou dimensões desproporcionais para a sua época. No sítio Laguinho e o Lago do Limão há presença de sepultamento humano, entretanto em ambos os casos estes se encontravam fora de montículo e somente o indivíduo enterrado no Laguinho deve pertencer à fase Paredão.

\section{Intervenções fora dos montículos}

Com o intuito de compreender as ocupações do sítio Hatahara fora de áreas construídas, em áreas menos perturbadas e mais fáceis de serem interpretadas, várias unidades de "controle" foram abertas. A análise desses contextos confirmaram as hipóteses de Machado (2005) quanto a artificialidade dos montículos. Nas unidades de controle estão ausentes a camada monticular de número IV, onde se percebe a utilização da terra preta e da cerâmica como materiais construtivos. Por exemplo, nas unidades de controle abertas em 2008 (N1148W1576 e N1345W1260) notou-se contextos com pouca cerâmica e a profundidade da terra preta de aproximadamente $30-50 \mathrm{~cm}$, podendo estar mosqueado até os $70 \mathrm{~cm}$. Feições diversas também estão presentes nesses contextos, como é o caso de N1148W1576.

\section{Cemitério de urnas fora de montículo}

Durante as tradagens realizadas para coleta de solo em 2002 (Rebellato, 2007) foram detectados fragmentos de um vaso grande no nível $60-70 \mathrm{~cm}$, a área foi aberta e quatro recipientes grandes encontrados a menos de 100m em direção noroeste do 
montículo I. Em 2006 optou-se por voltar e conferir o local através de uma escavação mais ampla ao redor das primeiras (aproximadamente $12 \mathrm{~m}^{2}$ ), almejava-se uma compreensão mais aprofundada do contexto e identificação de um padrão de depósito. No total nove vasos foram encontrados nessa área (unidades: N1211W1423, N1211W1422, N1211W1421, N1210W1423, N1210W1422, N1210W1421, N1209W1423， N1209W1421， N1208W1423， N1208W1422， N1209W1422, N1210W1420, N1207W1423, N1207W1422, ver Figura 1), quase todos identificados como pertencentes à fase Manacapuru (Lima, 2008).

As descrições das camadas a seguir juntam informações provenientes das fichas de campo e de Lima (2008).

Quatro camadas foram identificadas nesse local. Indo de baixo para cima, da base da escavação até $100 \mathrm{~cm}$ de profundidade encontra-se material cerâmico da fase Açutuba e as bases de alguns recipientes que cortam o começo dessa camada I. As colorações da camada e das percolações seguindo a tabela Munsell são 10 YR 6/8 (brownish yellow) e 10 YR 3/3 (dark brown).

A camada II representa uma transição entre solos escuros, com uma textura argilo-arenoso. A cor dessa camada é 10YR3/2 (very dark grayish brown) e está situada entre 50 ate 80/100cm de profundidade. De acordo com Lima (2008) entre 40 e $70 \mathrm{~cm}$ de profundidade diminui a quantidade de material Paredão e aparece o material Manacapuru acompanhado de um clareamento do solo. Nessa camada há uma grande quantidade de bioturbações e aumenta a presença de material cerâmico fase Açutuba a partir dos $70 \mathrm{~cm}$. Oito recipientes Manacapuru e um piso de ocupação foram identificados nessa camada.

A camada III tem cor 10YR 3/1 (very dark gray) e a textura é argilo-arenosa. Várias feições Paredão foram encontradas. A maior quantidade de material cerâmico dessa camada foi encontrada entre os níveis $10 / 20 \mathrm{~cm}$ a $40 / 50 \mathrm{~cm}$.

Os primeiros $10 / 20 \mathrm{~cm}$ correspondem ao solo impactado pelas atividades agrícolas com pouco material, mas o material presente nessa camada IV, até aproximadamente os $40 \mathrm{~cm}$ de profundidade, pertencem à fase Paredão e estão em terra preta (10YR 3/1 very dark gray).

Dentro das urnas escavadas havia farelos de ossos e alguns dentes humanos, de adultos e crianças. O material estava em péssimo estado de conservação. É 
interessante notar que algumas urnas eram compostas somente de “tampas”, quer dizer com vasos invertidos sobre o que deveria ser o sepultamento. 


\section{HATAHARA - RECIPIENTES E FEIÇÕES}
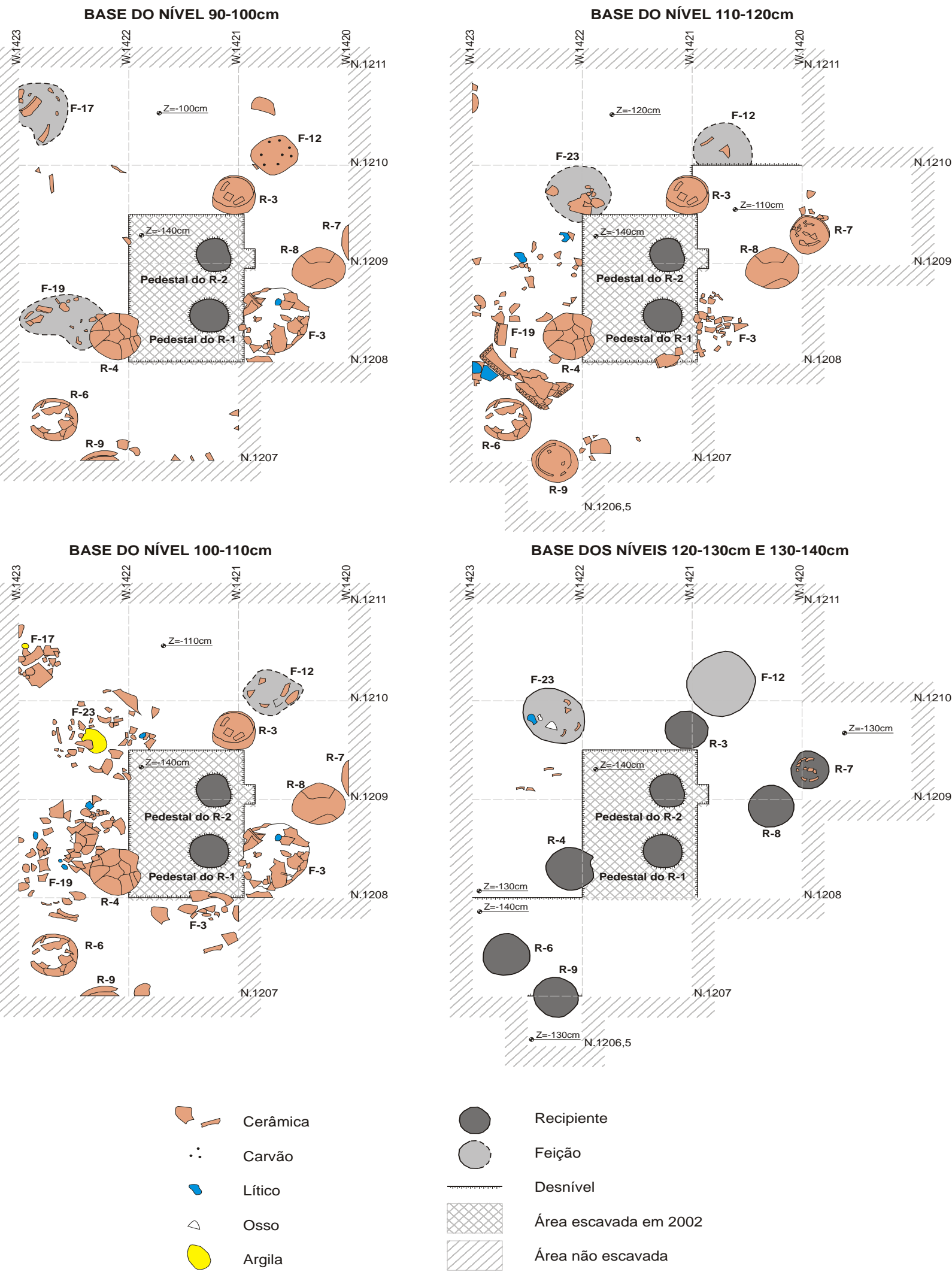

Arte final: Marcos Brito / 2008

Figura 1: Planta baixa da área onde as urnas Manapacuru foram encontradas. 


\section{Unidades de controle}

Várias unidades de controle estratigráfico foram abertas próximas aos montículos, mas fora da área de influência direta destes. O objetivo dessas unidades era de conhecer o processo de deposição natural (ou não construído) das camadas arqueológicas. Em geral essas escavações continham uma quantidade muito menor de cerâmica e terra preta, como mencionado mais acima. Como exemplo de unidade de controle falaremos de N1148W1576 escavada em 2008 aberta perto do montículo IV.

Em relação ao grid ela se encontra a oeste. Foi interessante perceber que a camada de terra preta não é muito profunda, entre 40 e $50 \mathrm{~cm}$ e, que nela constma essencialmente fragmentos cerâmicos da fase Guarita. Foram identificadas feições que cortam as camadas mais amareladas, nelas há fragmentos grandes que devem ser mais bem analisados, pois podem pertencer a fase Açutuba.

A descrição das camadas se baseia no perfil norte de N1148W1576 (ver figura 2). As referências de profundidade estão em relação ao DATUM de $10 \mathrm{~cm}$ mais alto que a superfície.

A primeira camada (I) dessa unidade é estéril com latossolo muito compactado, ela começa a partir de $85 \mathrm{~cm}$ de profundidade e tem coloração 10YR 8/8 (yellow) e textura argilosa.

A camada II representa uma transição entre a terra preta e o latossolo, nela há uma grande quantidade de material cerâmico (possivelmente Açutuba) e carvão. A cor dessa camada varia entre 10YR4/6 (dark yellowish brown) e 10 YR 6/8 (brownish yellow). O solo

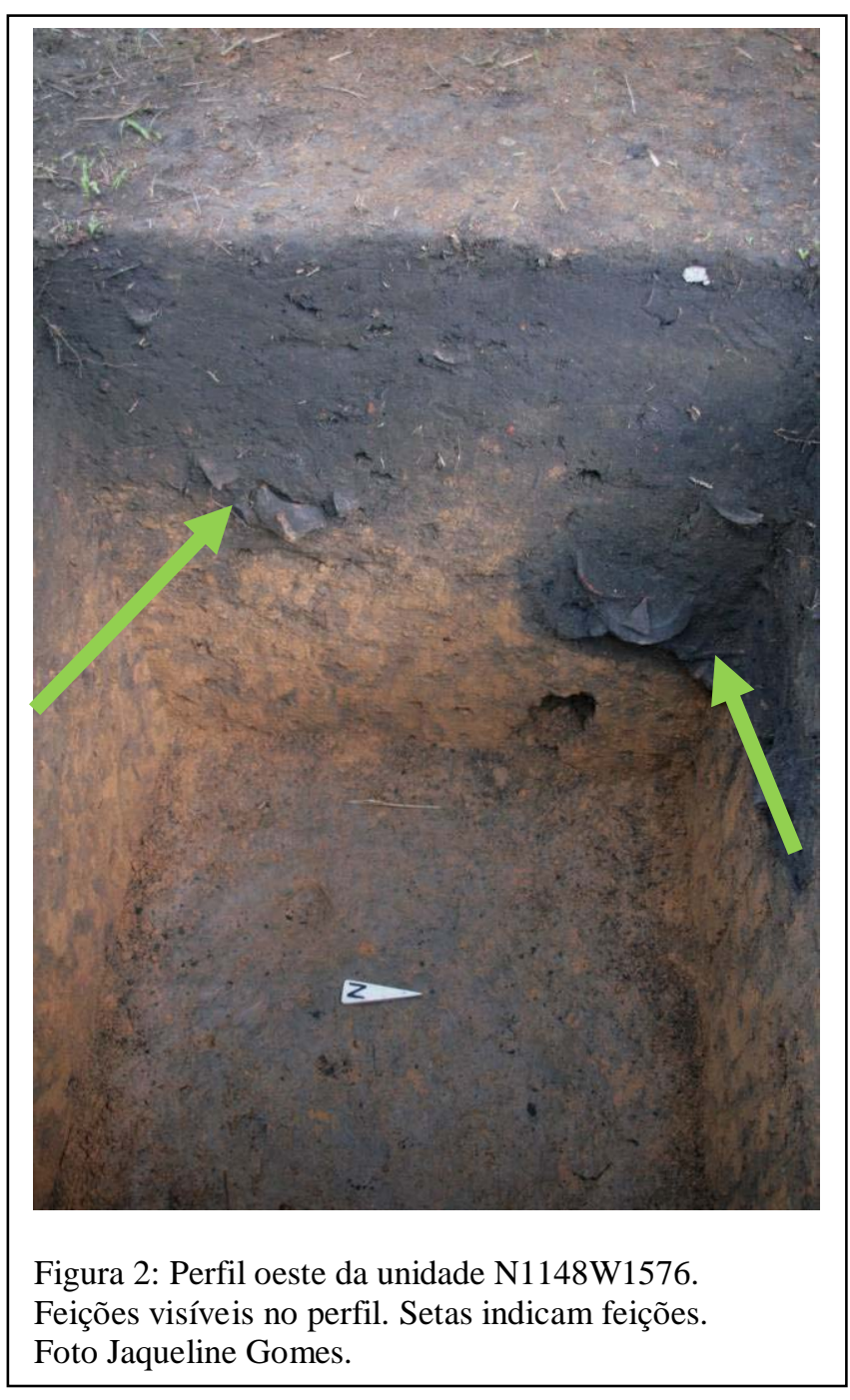
é muito argiloso e a camada está situada ente 40 e $85 \mathrm{~cm}$ de profundidade. 
A ocorrência de cerâmicas se faz em média proporção na camada III, nesta há presença de bioturbações e muitas radículas. O sedimento é argiloso e de coloração 10 YR 3/2 (very dark grayish brown) de acordo com a tabela Munsell. Esta camada está presente entre 15 e $40 \mathrm{~cm}$ de profundidade.

A camada mais superficial é a IV, o sedimento aqui é pouco compactado, muito impactado pelo plantio, com presença de muitas radículas. Esta camada se encontra entre 10 e 15 cm de profundidade em relação ao DATUM. A coloração é 10 YR 2/1 (black).

\subsection{Ocupações}

Os dados obtidos desde 1999 nos permitem classificar o sítio Hatahara como multicomponencial, marcado por uma seqüência de ocupação de quatro fases distintas, duas delas e, provavelmente três, associadas de alguma forma à terra preta antropogênica.

Dezenas de dataçõess foram realizadas para esse sítio, o que faz dele o sítio mais bem datado de toda região (Arroyo-Kalin, 2008; Lima, 2008) (ver Tabela 1). Entretanto, muitas datas obtidas para as camadas de construção dos montículos não podem ser utilizadas, pois elas estão fora de seus contextos originais. Machado (2005), verificou que houveram vários casos de inversão das datas obtidas (datas mais recentes estavam mais profundas do que as datas mais antigas) na camada de construção do montículo. Isso aconteceu porque para construir os montículos, terra, cerâmica e diversos fragmentos de outros materiais (carvão, osso, lítico, sementes, etc.) foram levados e quando depositados, as camadas superiores de outras áreas (portanto mais recentes) ficaram por baixo de camadas mais profundas (mais antigas).

Tabela 1: Datas obtidas para o Sítio Hatahara

\begin{tabular}{|l|r|r|r|l|l|r|l|l|}
\hline & \multicolumn{2}{|c|}{} & & \multicolumn{3}{|c}{ Data } & Data \\
Laboratório & Código & Idade & Profundidade & Amostra & Contexto & PN & AP & AC/DC \\
\hline Beta & 143582 & 350 & 29 & Carvão & N1152W1360 & 222 & 395 BP & 1555 AD \\
\hline Beta & 143585 & 980 & 58 & Carvão & N1152W1360 & 1879 & 865 BP & 1085 AD \\
\hline Beta & 143586 & 960 & 60 & Carvão & N1152W1360 & 1880 & 860 BP & 1090 AD \\
\hline Beta & 143587 & 570 & 65 & Carvão & N1152W1360 & 1882 & 585 BP & 1365 AD \\
\hline Beta & 145485 & 2650 & 70 & Osso & N1152W1360 & 1564 & 2770 & 820 BC \\
\hline
\end{tabular}




\begin{tabular}{|c|c|c|c|c|c|c|c|c|}
\hline & & & & & & & $\mathrm{BP}$ & \\
\hline & & & & & & & 1015 & \\
\hline Beta & 145486 & 1130 & 70 & Osso & N1152W1360 & 1578 & BP & $935 \mathrm{AD}$ \\
\hline Beta & 143588 & 1000 & 80 & Carvão & N1152W1360 & 1881 & $895 \mathrm{BP}$ & $1055 \mathrm{AD}$ \\
\hline Beta & 143589 & 1000 & 84 & Carvão & N1152W1360 & 505 & $895 \mathrm{BP}$ & $1055 \mathrm{AD}$ \\
\hline Beta & 178914 & 970 & 108 & Carvão & N1155W1360 & 10688 & $865 \mathrm{BP}$ & $1085 \mathrm{AD}$ \\
\hline Beta & 143592 & 910 & 121 & Carvão & N1152W1360 & 589 & $845 \mathrm{BP}$ & $1105 \mathrm{AD}$ \\
\hline Beta & 178917 & 1000 & 123 & Carvão & N1155W1360 & 10737 & $895 \mathrm{BP}$ & \begin{tabular}{|l}
$1055 \mathrm{AD}$ \\
\end{tabular} \\
\hline Beta & 143593 & 1070 & 130 & Carvão & N1152W1360 & 1840 & $995 \mathrm{BP}$ & $955 \mathrm{AD}$ \\
\hline Beta & 145483 & 1580 & 140 & Osso & N1152W1360 & 1739 & $\begin{array}{l}1465 \\
\text { BP }\end{array}$ & $485 \mathrm{AD}$ \\
\hline Beta & 145484 & 1390 & 140 & Osso & N1152W1360 & 1798 & $\begin{array}{l}1310 \\
\text { BP }\end{array}$ & $640 \mathrm{AD}$ \\
\hline Beta & 178915 & 880 & 146 & Carvão & N1155W1360 & 10714 & $820 \mathrm{BP}$ & \begin{tabular}{|l|}
$1130 \mathrm{AD}$ \\
\end{tabular} \\
\hline Beta & 143595 & 960 & 155 & Carvão & N1152W1360 & 1892 & $860 \mathrm{BP}$ & $1090 \mathrm{AD}$ \\
\hline Beta & 178918 & 940 & 172 & Carvão & N1155W1360 & 10740 & $855 \mathrm{BP}$ & $1095 \mathrm{AD}$ \\
\hline Beta & 178916 & 1150 & 180 & Carvão & N1155W1360 & 10729 & $\begin{array}{l}1060 \\
\text { BP }\end{array}$ & $890 \mathrm{AD}$ \\
\hline Beta & 143599 & 1300 & 192 & Carvão & N1152W1360 & 1873 & $\begin{array}{l}1235 \\
\text { BP }\end{array}$ & $715 \mathrm{AD}$ \\
\hline Beta & 143591 & 1250 & $100-110$ & Carvão & N1152W1360 & 549 & $\begin{array}{l}1180 \\
\text { BP }\end{array}$ & $770 \mathrm{AD}$ \\
\hline WK & 16223 & 1105 & $105-110$ & $\mathrm{mCh}$ & M-II 3/21 & 10173 & $\begin{array}{l}1010 \\
\text { BP }\end{array}$ & $940 \mathrm{AD}$ \\
\hline Beta & 143594 & 890 & 140-150 & \begin{tabular}{|l|} 
Carvão \\
\end{tabular} & N1152W1360 & 1848 & $825 \mathrm{BP}$ & $1125 \mathrm{AD}$ \\
\hline Beta & 143596 & 1070 & \begin{tabular}{|l|}
$160-170$ \\
\end{tabular} & Carvão & N1152W1360 & 1855 & $995 \mathrm{BP}$ & $955 \mathrm{AD}$ \\
\hline WK & 16224 & 1191 & $165-170$ & mCh & M-II 3/33 & 10185 & $\begin{array}{l}1120 \\
\text { BP }\end{array}$ & $830 \mathrm{AD}$ \\
\hline Beta & 143597 & 2310 & $170-180$ & Carvão & N1152W1360 & 1860 & $\begin{array}{l}2400 \\
\text { BP }\end{array}$ & $450 \mathrm{BC}$ \\
\hline Beta & 143598 & 1080 & 180-190 & \begin{tabular}{|l} 
Carvão \\
\end{tabular} & N1152W1360 & 1869 & $995 \mathrm{BP}$ & $955 \mathrm{AD}$ \\
\hline Beta & 143583 & 1010 & $30-40$ & Carvão & N1152W1360 & 361 & $920 \mathrm{BP}$ & $1030 \mathrm{AD}$ \\
\hline Beta & 143584 & 1250 & $40-50$ & Carvão & N1152W1360 & 394 & $\begin{array}{l}1180 \\
\text { BP }\end{array}$ & $770 \mathrm{AD}$ \\
\hline WK & 16222 & 2269 & $60-65$ & $\mathrm{mCh}$ & M-II 3/13 & 10165 & $\begin{array}{l}2260 \\
\text { BP }\end{array}$ & $310 \mathrm{BC}$ \\
\hline Beta & 202681 & 930 & & Carvão & & 2046 & $850 \mathrm{BP}$ & $1100 \mathrm{AD}$ \\
\hline Beta & 242439 & 1080 & $100-110$ & Osso & N1152W1359/60 & 1175.5 & $980 \mathrm{BP}$ & $970 \mathrm{AD}$ \\
\hline
\end{tabular}


De maneira mais resumida podemos perceber quatro momentos de ocupação: 1) uma ocupação mais antiga relacionada à cerâmica da fase Açutuba, sem relações com a terra preta, por volta de 300AC a 350DC. Nessa fase, tem-se como antiplástico a ocorrência de cariapé adicionado à pasta de argila, predominância de formas irrestritivas, decoração variada com motivos incisos curvilíneos, excisões sobre engobo vermelho, acanalados, apêndices zoomorfos, flanges labiais, flanges mesiais, engobo branco e pintura policrômica (Lima et al., 2006; Neves et al., 2007).

2) uma ocupação posterior relacionada à cerâmica da fase Manacapuru, aparentemente também dissociada da terra preta, que começa por volta de 550 650DC. Na cerâmica dessa fase ocorre principalmente cauixí como antiplástico na pasta de argila, predominância de formas restritivas, decoração variada com incisões retilíneas duplas, ponteado, apêndices zoomorfos, flanges labiais e engobo vermelho (Hilbert, 1968; Neves et al., 2003).

3) uma ocupação mais densa do sítio está relacionada à cerâmica da fase Paredão, associada à terra preta e à construção dos montículos, datada aproximadamente entre 750 e 1020DC. Nessa fase encontra-se uma predominância de cauixí adicionado à pasta de argila, vasos com paredes muito finas e bem queimadas, presença de vasos com alças, vasos com pedestais, decoração com incisões em linhas finas, pintura também em linhas muito finas, engobo vermelho e apliques antropomorfos estilizados (as cabecinhas Paredão) associados às urnas funerárias. É a esse período que é atribuído uma estrutura social relacionada aos cacicados (Hilbert, 1968; Neves et al., 2003).

4) a ocupação mais recente e mais superficial, está relacionada à fase Guarita, e à presença de terra preta, datada entre 950 e 1450DC. As características da cerâmica da fase Guarita são predominância de cariapé adicionado à pasta de argila, ocorrência de vasos com borda reforçada, decoração policrômica com motivos geométricos (faixas grossas e linhas finas), decoração plástica acanalada, urnas funerárias antropomorfas, vasos com flange mesial, ocorrência de engobo branco e vermelho (Hilbert, 1968; Neves et al., 2003).

Em função dessas definições e distinções dos complexos cerâmicos, foi possível mapear, através da análise do material e da estratigrafia das tradagens, a região central como local de intensas re-ocupações, onde foram encontradas 
cerâmicas pertencentes às fases Manacapuru, Paredão e Guarita. Por outro lado, a porção centro-leste é caracterizada por uma maior presença de cerâmica da fase Paredão e, a zona norte e oeste do sítio à cerâmica Manacapuru (Rebellato, 2007; Tamanaha e Rapp Py-Daniel, 2009). As ocupações pertencentes às fases mais antigas são difíceis de serem mapeadas pois a concentração de material é menos intensa e as tradagens não alcançam a profundidade necessária na maior parte das vezes.

\subsection{Análises químicas do solo}

Em 2007, Lillian Rebellato apresentou um mestrado com ênfase nas análises químicas do solo do sítio Hatahara. Através desse trabalho Rebellato identificou dois padrões de ocupação correspondendo às fases Guarita e Paredão:

- A ocupação relacionada à ocupação Paredão, apresentou forma circular e um longo período de ocupação entre 650-1000 D.C no sítio ... Este assentamento, apresentou uma praça central, com aproximadamente 150m de diâmetro, como observado ...(de acordo com a) concentração de fósforo e distribuição de terra preta. Ao observar os resultados (pg 177 e 178).

- A segunda forma de aldeia identificada refere-se à última ocupação no sítio, entre 1000 a 1300 D.C, relacionada à cerâmica Guarita, com um padrão linear de disposição das casas, acompanhando o leito do rio Solimões, sobre o terraço onde se localiza o sítio Hatahara. (pg 178).

Nesse mesmo trabalho Rebellato (2007) também afirma que os sepultamentos devem todos ter ocorrido ao mesmo tempo no montículo I

- Neste local, constatamos a seguinte correspondência: nos níveis onde encontramos alta incidência de fósforo também ocorre a elevação dos teores de cálcio, ou seja, nos níveis 50 e $90 \mathrm{~cm}$. Podemos perceber também que no nível $70 \mathrm{~cm}$ não há uma elevação significativa de cálcio como nos níveis 50 e $90 \mathrm{~cm}$, corroborando para a hipótese de um sepultamento que ocorreu posteriormente, não no nível $90 \mathrm{~cm}$, mas no $50 \mathrm{~cm}$, vinculando este fato a ocupação Paredão. Outra informação apontada por esses dados relaciona-se ao tempo de ocorrência desse evento. Isto é, os 22 sepultamentos foram 
depositados simultaneamente, pois se houvesse variação no tempo de deposição dos mesmos, no nível $70 \mathrm{~cm}$ também apresentaria uma elevação nos teores de cálcio e fósforo, devido ao revolvimento do solo para a deposição dos mortos.” (pg. 163).

Mais detalhes sobre a presença de certos elementos químicos e a conservação e disposição dos sepultamentos serão discutidos posteriormente.

\subsection{Fase Paredão}

Aqui a ênfase será dada à fase Paredão, visto que os sepultamentos estudados estão ligados à ela. Quase todas as fases arqueológicas criadas para a Amazônia Central foram definidas por Peter Paul Hilbert (1968), uma exceção sendo a fase Açutuba, definida por Lima et. al (2006). Com o avanço dos trabalhos arqueológicos as fases foram adquirindo mais características e se solidificando como instrumentos de organização cronológicos e culturais. O essencial desse mestrado foi realizado em cima de vestígios da fase Paredão, datada entre os séculos VII e XIII de nossa era.

Depois de Hilbert, o PAC pôde afinar a cronologia da região datando dezenas de amostras de carvões e cerâmicas. Alguns trabalhos acadêmicos recentes estudaram em detalhes a cerâmica relacionada à fase Paredão. Dentre eles podemos citar Donatti (2002), Machado (2005), Moraes (2006) e Tamura (2005) A cerâmica dessa fase é muito elaborada, a pasta é depurada, a queima muito bem controlada (Moraes, 2006). A decoração das cerâmicas é menos exuberante do que nas fases anteriores e a posterior, entretanto elas são muito bem acabadas, com polimento e incisões muito precisas (Moraes, 2006). Exemplos de formas exclusivas da fase Paredão são: cuia com pedestal, cesta com alça e vasos com bordas irregulares e diâmetro oval (Moraes, 2006), além disso tem os apliques antropomorfos estilizados (as cabecinhas Paredão) associados às urnas funerárias (Rapp Py-Daniel et al.,

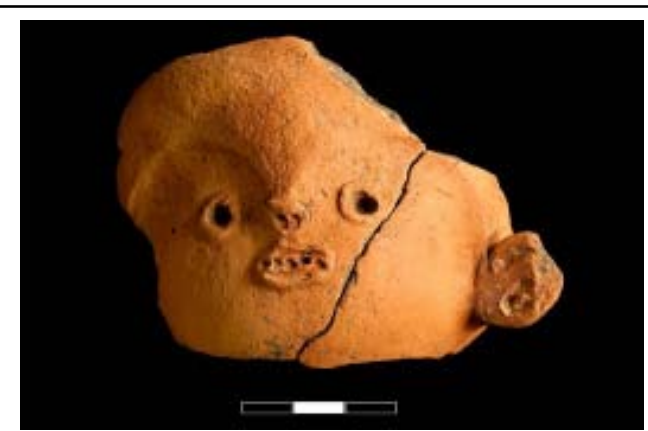

Figura 3: Cabecinha Paredão, aplique típico das urnas funerárias da fase Paredão. Foto de Wagner Souza e Silva. 2009). Algumas formas típicas, mas não exclusivas, são: potes com gargalo, assadores, tigelas, pratos e urnas funerárias com apliques antropomorfos (Figura 3). 
Nessas cerâmicas encontra-se uma predominância de cauixí adicionado à pasta de argila.

Há vestígios associados à fase Paredão essencialmente nos arredores de Manaus e Iranduba, área de atuação do PAC (Neves e Petersen, 2006). A essa fase está relacionado um padrão de assentamento circular em montículos (Moraes, 2006; Rebellato, 2007). Moraes (2006) encontrou vários sítios unicomponenciais com presença de montículos e seqüências longas de ocupação (sítio Pilão e sítio Antônio Galo).

Os pesquisadores atuando na região trabalham com a hipótese de que existe continuidade entre as fases Manacapuru e Paredão (Moraes, 2006; Lima, 2008) e que seu aparecimento está correlacionado a um aumento populacional (Moraes, 2006). A morfologia e alguns elementos decorativos se assemelham. Também é comum em sítios unicomponenciais presença de cerâmicas da outra fase (Portocarreiro, 2007, Moraes, 2006). Portocarreiro (2007) descreve em seu trabalho um padrão de assentamento circular para um sítio Manacapuru, prática mais freqüentemente relacionada à fase Paredão. 


\section{FUNDAMENTAÇÃO TEÓRICA: CONCEITOS SOBRE A ARQUEOLOGIA DA MORTE E A TAFONOMIA}

Aqui serão apresentados os conceitos teóricos básicos da arqueologia da morte e da tafonomia que conduziram e estruturaram o nosso pensamento durante a análise de campo, de laboratório e a redação dessa dissertação.

Esse capítulo está dividido em três partes. Num primeiro momento será apresentado o conceito geral de arqueologia da morte, fazendo um resumo do histórico, contextualizando as pesquisas no Brasil, abordando as premissas principais e sublinhando sua importância dentro da arqueologia como um todo. Em seguida uma síntese do que é a tafonomia, como ela está integrada à arqueologia da morte e quais elementos devem ser estudados, será apresentado.

O objetivo nesse momento é mostrar a complementaridade das duas disciplinas com a arqueologia no que diz respeito ao estudo de populações do passado através dos vestígios humanos.

\subsection{A Arqueologia da Morte}

A arqueologia da morte pode ser considerada como uma sub-disciplina da arqueologia que interage de maneira íntima com a antropologia física, a antropologia forense (ou arqueologia forense) e principalmente a tafonomia. Essa última será vista em mais detalhes na segunda parte desse capítulo.

\subsubsection{As Origens da Arqueologia da Morte}

Nesse trabalho são utilizados principalmente as premissas dos trabalhos pioneiros de Henri Duday, que junto com Claude Masset, definiu a "anthropologie de terrain” ${ }^{\prime 6}$ no Colóquio de Toulouse de 1982 (Duday e Masset, 1986). Em 2005, o próprio Henri Duday, passaria a chamar sua abordagem de "arqueotanatologia"7. Duday diferencia a arqueotanatologia da arqueologia funerária, pois esta em geral

\footnotetext{
${ }^{6}$ A tradução literal do termo anthropologie de terrain é "antropologia de terreno”, mais conhecida como arqueologia funerária no Brasil.

${ }^{7}$ A definição de arqueotanatologia de acordo com o próprio Duday (2005) é o estudo da morte através da arqueologia.
} 
teve como objeto de estudo o material de acompanhamento, situação paradoxal, já que um sepultamento é feito para um morto e não para seus objetos (Duday, 2005).

O conceito proposto por Duday $(1986,2005)$ parece se aproximar do conceito de “arqueologia da morte” tal qual ele aparece em português e é empregado por Neves (1984) e Silva (2005: 10-11). Entretanto, as condições de conservação e os contextos nos quais estão os sepultamentos nas Américas são muito diferentes dos encontrados na Europa, fazendo com que haja uma aproximação natural dos pesquisadores brasileiros com os pesquisadores norte-americanos e os conceitos por eles utilizados, por exemplo, Buikstra e Ubelaker (1994).

No Brasil encontra-se uma situação complexa pois poucos pesquisadores trabalham com a arqueologia da morte e geralmente os estudos que se aproximam estão mais focados na paleopatologia humana. Como afirma Mendonça de Souza et al. (2001), o pouco de informação que temos, no Brasil, sobre os contextos funerários provém de descrições rápidas, fragmentadas e meio que por “acaso" nos trabalhos e artigos, pois o objetivo geralmente é outro e as análises ósseas e de sepultamento são vistas como pertencente à outra área de conhecimento. Além disso, enfrenta-se ainda um grande preconceito e desconhecimento sobre o potencial dessas pesquisas, assim muitos achados de sepultamento são considerados como transtornos, pois exigem metodologias específicas do campo até o laboratório (Mendonça de Souza et al., 2001:481-482).

Baseando-se principalmente nos trabalhos de precursores americanos (como Buikstra e Ubelaker, 1994), a pesquisadora Lillian Cheuiche Machado foi responsável por grande parte dos trabalhos feitos no Brasil sobre a arqueologia da morte. Cheuiche Machado, não menciona em seus textos o termo arqueologia da morte, ela fala de “pesquisa interdisciplicar em arqueologia funerária e osteologia e dentição humana” (Machado, 2006b:25) como parte da bioarqueologia. Seus textos afirmam a necessidade de comunhão entre a arqueologia a as análises dos contextos dos sepultamentos e dos vestígios ósseos.

Masset (1986) definiu quais são as principais informações que podem ser retiradas do estudo de sepultamentos: 1- As intervenções pré-sepulcrais no morto; 2O modo de deposição dentro da sepultura (estruturação do sepultamento); 3-A tafonomia dos ossos dentro da sepultura após deposição definitiva; 4- Reconstrução 
de populações vivas; 5- Datação; 6- NMI (número mínimo de indivíduos); 7-Aspectos morfológicos ("raças” e patologias); 8- Informações "sociais”; 9- A procura de similaridades entre vários indivíduos.

Dentro desses itens percebe-se a menção da "Tafonomia” como objetivo da arqueotanatologia. Depois do Colóquio de Toulouse muitos avanços foram feitos para integrar cada vez mais essa disciplina à arqueologia como um todo e não somente à arqueologia da morte. Como será visto, os estudos tafonômicos permitiram uma compreensão mais clara dos processos de alteração dos ossos (Haglund e Sorg, 1997a e 1997b). Mas não somente, pois ela permitiu também uma avaliação mais precisa da evolução dos sepultamentos pelos processos de decomposição.

Em Cheuiche Machado estão presentes esses mesmos objetivos com uma ênfase mais “arqueológica”:

- tipo de sepultamento e tratamento dado ao corpo; b) características das diferentes condições em que foi depositado o corpo; c) características dos diferentes elementos colocados com o corpo no sepultamento (associação, número e tipo de acompanhamento funerário); d) localização espacial $e$ estratigráfica dos sepultamentos e em relação às demais estruturas evidenciadas no sítio; e) orientação magnética; f) forma, dimensão e características da cova (Machado, 1995). Estas variáveis são correlacionadas aos dados bioesqueletais avaliados, como idade, sexo, número total de indivíduos e condições patológicas (2006b:26).

Obviamente a quantidade e o tipo de informações que serão retiradas dos contextos funerários dependem da preservação do conjunto. Como menciona Cheuiche Machado em vários de seus trabalhos (2006a; 2006b) a fragmentação e a preservação do material influenciam na precisão das identificações e na possibilidade de aplicar os diversos métodos para estimar idade, sexo e patologias.

No caso do material estudado nesse projeto a conservação é ruim, assim, o potencial informativo é menor, por isso os objetivos gerais apresentados por Masset (1986) foram direcionados para o contexto dos sepultamentos no sítio Hatahara e ênfase foi dada à: identificação das intervenções pré-sepulcrais; o modo de deposição dentro da sepultura; observação da tafonomia; datação absoluta ou relativa dos sepultamentos e do contexto; estimativa do número mínino de indivíduos; e aquisição de informações sociais. Além disso, como propõe Cheuiche Machado procurou-se 
obter informações sobre a localização do sepultamento dentro do sítio arqueológico e de seus arredores imediatos.

\subsubsection{O que é a Arqueologia da morte?}

A arqueologia da morte visa, através da interdisciplinaridade, preencher lacunas existentes entre a arqueologia e a antropologia física. Assim propõe a análise de sepultamentos e do contexto funerários utilizando conhecimentos de ambas as disciplinas, além de técnicas de outras áreas, permitindo que mais informações sejam retiradas dos contextos funerários. No caso do arqueólogo, conhecer a anatomia humana permite uma melhor avaliação das estruturas funerárias, de como escavar, de quais procedimentos adotar, de como avaliar a evolução de um sepultamento, etc. Enquanto que, para o antropólogo físico, a arqueologia traz informações indispensáveis sobre o contexto no qual o, ou os sepultamentos, estão inseridos e como esse contexto influencia ou é influenciado pela presença de vestígios, ações humanas e intempéries naturais.

Segundo alguns autores (Duday, 2005; Roksandic, 2002) parte da compreensão da evolução dos sepultamentos passa pela identificação:

1- Das conseqüências da decomposição das partes moles;

2- Das seqüências de desarticulação ou desintegração do tecido conectando os ossos;

3- Das amplitudes potenciais de movimento dos elementos esqueléticos.

Algumas etapas práticas para fazer essas identificações (Duday, 2005: 154) são:

a) Identificar em campo cada peça ou fragmento ósseo;

b) Reconhecer a posição exata dos ossos, suas orientações anatômicas e a relação com os outros ossos;

a. Identificar os processos de organização da estrutura;

c) Identificar a relação com os outros elementos do sepultamento (arquitetura, artefatos);

d) Ter um raciocínio retrospectivo sobre a posição dos elementos, da forma da cova, da preparação do corpo, etc.

Essas etapas, de estudo específico do corpo e do sepultamento, associadas a observações contextuais do sítio arqueológico em geral, permitem mostrar a 
intencionalidade de um sepultamento e traduzem os gestos funerários, diferenciandoos das ações naturais.

Vários autores chamam a atenção para esse quesito, pois o fato de encontrar um corpo não é sinônimo de encontrar um sepultamento, uma vez que o encontro de um corpo pode traduzir um evento de morte natural, um local de batalha, um esconderijo, etc. No termo sepultamento está implícito o desejo de uma comunidade de vivos de tomar conta de seus mortos (Lefevre apud Duday, 2005).

Alguns dos gestos que podem ser identificados são: práticas preparatórias ou tratamentos pré-sepulcrais do cadáver (antes do enterramento); práticas sepulcrais (estrutura da cova, posição do corpo e material funerário); práticas pós-sepulcrais (reabertura da cova, manipulação das ossadas, redução, re-inumação) (Duday, 2005). Tais análises se diferenciam das análises tafonômicas strictu sensu (Duday, 2005), que nós veremos em mais detalhe na próxima parte.

Parte do quadro teórico da arqueologia da morte almeja o reconhecimento de um padrão (Masset, 1986). A repetição de certo gesto ou grupo de gestos estaria ligada a um hábito, provavelmente ritualístico (Silva, 2005). Entretanto, já fora chamada a atenção por Sheila Mendonça de Souza (comunicação pessoal em congresso) que variações dos gestos percebíveis talvez não sejam significativos. Nesse caso o padrão poderia ser um conceito e não um gesto específico, o que torna o seu reconhecimento através da arqueologia extremamente difícil.

Mendonça de Souza et al. (2001) afirmam que os conjuntos de dados biológicos, culturais e tafonômicos - fornecidos pelo estudo dos sepultamentos e dos vestígios humanos diretos são necessários para a reconstituição pré-histórica (2001:482).

- .... se deve tentar resgatar.... a transformação dos cemitérios e seus conteúdos, desde o momento em que se constituiu o espaço funerário, até a intervenção do pesquisador (ibid:483).

Assim, a análise “arqueotanatológica” se funda sobre esses vários fatores: observações contextuais do sepultamento associadas às observações de processos tafonômicos, sempre com o esqueleto humano sendo levado em consideração (Duday, 2005). Essa associação de métodos visa compreender melhor a evolução dos sepultamentos e os gestos funerários praticados pelos vivos sobre o morto. 
Dentre algumas pesquisas no Brasil encontram-se a aplicação desses objetivos. Por exemplo, Müller (2008), apresenta um estudo relacionando o material humano encontrado ao local, o tipo de tratamento destinado ao corpo, os dados etnográficos e o contexto arqueológico como um todo.

Outro trabalho relacionado à interpretação de gestos funerários é o de Plens (2007), onde a pesquisadora analisa o sítio arqueológico Moraes como uma estrutura funerária, relacionando todos os elementos encontrados no local aos diversos sepultamentos e seus contextos.

\subsection{O que é a Tafonomia?}

A tafonomia é uma ciência com aplicações na área de ciências naturais e humanas sendo utilizada dentro da arqueologia principalmente em contextos funerários (recentes ou antigos) e zooarqueológicos, mas também para a produção de dados fundamentais para a interpretação dos processos de ocupação dos sítios arqueológicos. Diferente de outros estudos de formação de contextos arqueológicos, a tafonomia foi inicialmente um estudo relacionado à passagem dos seres vivos a fósseis, no entanto, com o tempo e a diversificação das pesquisas, suas definições estão ficando mais abrangentes.

\subsubsection{Definição}

A palavra tafonomia foi usada pela primeira vez por um cientista russo chamado Yefremov em 1940 (Haynes, 1997; Martin, 1999), e literalmente seu significado é “as leis de enterramento” (Marshall, 1989). Entretanto os conceitos por trás da palavra já estavam sendo utilizados há vários séculos para compreensão dos processos de transformação das matérias (Martin, 1999).

Definir a tafonomia é algo simples e complexo ao mesmo tempo, pois os autores definem processos tafonômicos de acordo com suas problemáticas de pesquisa. A tafonomia difere nas distintas disciplinas principalmente por causa do foco específico de cada uma, enquanto algumas procuram entender processos de alteração dos restos humanos imediatamente após a morte (antropologia forense), outras visam a compreensão dos eventos de longa duração que podem afetar os ossos (paleontologia). Outras ainda utilizam os estudos em tafonomia como ferramenta para 
compreender relações amplas e complexas entre diversos processos deposicionais que podem ter ossos ou outros vestígios como elemento central do estudo (arqueologia).

Uma das definições mais amplas para o termo “tafonomia” é a de Olsen (1980, apud Haglund e Sorg, 1997a), na qual o estudo da tafonomia estaria centrado na reconstrução da história de um fóssil desde o momento em que ele morre até o momento de sua descoberta, incluindo todos os aspectos de passagem dos organismos da biosfera até a litosfera. No caso do material arqueológico, muitas vezes os esqueletos encontrados estão sofrendo processos destrutivos e não virariam fósseis (litosfera), mas isso não impede que os processos sejam estudados.

Como o presente estudo busca muito de seus métodos de trabalho dentro da área forense foi interessante encontrar um autor, Nordby (2002), que ao contrário dos outros, apresentasse de maneira complementar as lacunas da disciplina.

- Forensic taphonomy may at this time exist as a collection of hodge-podge theories, pasted together from many sciences, mixed with archaeological practices, and loosely accumulated to defend case specific explanations and guide the discovery, investigation, and eventual explanation of specific decomposing human (or other) remains. However to establish a scientific gauntlet for forensic taphonomy as punishment for its currently underdeveloped theoretical perspectives ignores the theoretical growth of gradually maturing natural sciences for the last 2000 years (Neugerbauer). ${ }^{8}$ (Nordby, 2002, pg. 32).

Nordby apresenta a tafonomia como disciplina dinâmica e é nesse espírito que vamos continuar. As lacunas apresentadas em vez de inviabilizar a pesquisa, ao contrário forçam análises que considerem mais variáveis. Como existe essa grande variedade de definições para a tafonomia, há também uma ausência de protocolo de análise fixo.

\footnotetext{
${ }^{8}$ Tradução da autora: A tafonomia forense pode, nesse momento, existir como um aglomerado bagunçado de fundamentos teóricos, colados juntos de várias ciências, misturados com práticas arqueológicas, e acumulado soltamente para defender explicações de casos específicos e guiar a descoberta, investigação e eventual explicação de restos humanos (ou outros) específicos. Entretanto, o estabelecimento de uma "regra" científica para a tafonomia forense como castigo pelas suas perspectivas teóricas ainda pouco desenvolvidas, ignora o crescimento teórico gradual para a maturação das ciências naturais nos últimos 2000 anos. (Nordby, 2002, pg. 32).
} 


\section{$\underline{\text { Premissas }}$}

A tafonomia assume que os processos estudados são uniformes (conceito de “uniformitarism”). Tal princípio nos permite induzir o que aconteceu no passado através do que acontece no presente (Martin, 1999), ele não pode ser provado, pois é impossível olhar o que acontecia no passado, mas utilizando a analogia e as pesquisas em "atualismo" (actualistic research) pode-se deduzir alguns processos (GiffordGonzales, 1989). Esse princípio assemelha-se à arqueologia experimental em alguns aspectos (ver Renfrew e Bahn, 2001 para arqueologia experimental) Esse método se baseia em relações processo-padrão análogos e observações de processos de formação de sítios atuais (Marshall, 1989) para compreender sítios antigos (Gifford-Gonzales, 1989). Um dos casos mais conhecidos foi a reavaliação dos dados do pesquisador Dart, que apresentava os australopitecos como produtores de instrumentos em osso (Marshall, 1989) utilizados para caçar. Comparando os conjuntos de vestígios deixados pelos carnívoros atuais e os arqueológicos, Brain (1989), percebeu que os primeiros hominídeos não estavam fabricando objetos, o conjunto de vestígios não eram de grandes caçadores e, sim de carniceiros ou presas (Brain, 1989; Haynes, 1997).

\subsubsection{Os objetivos}

Haglund e Sorg (1997a) definem os objetivos em tafonomia como sendo:

- Primary goals ... have included: (1) reconstructing paleoenvironments; (2) determining which factors cause differential destruction or attrition of bone; (3) understanding selective transport of remains; and (4) discriminating human from nonhuman agents of bone modification. ${ }^{9}$ (pg. 3).

Esses autores, mesmo tratando mais particularmente de tafonomia de enterramentos humanos recentes, sintetizam as grandes metas da tafonomia em geral. Além dessas metas podemos mencionar algumas questões levantadas por Bonnichsen (1989a) quanto a utilização da tafonomia para guiar as análises: Como conjuntos ósseos se formam? O que controla a distribuição espacial? Que fatores afetam a freqüência das dimensões dos conjuntos? Como são afetadas a superfície e a estrutura interna e externa dos ossos? Como tipos diferentes de elementos ósseos ficaram

\footnotetext{
${ }^{9}$ Tradução da autora: Seus principais objetivos... incluíram: (1) reconstruir paleo-ambientes; (2) determinar quais fatores causam destruição diferencial ou atrito dos ossos; (3) compreender transporte seletivo de restos; e (4) determinar agentes humanos e não-humanos para a modificação óssea.
} 
associados? E, o que essa nova informação pode nos ensinar sobre a história e desenvolvimento dos sistemas culturais e ambientais?

Dentro dos estudos existe a necessidade de padronizar e de multiplicar análises e experiências que permitam identificar os traços encontrados nos ossos. Mas a tafonomia visa ir além, criando, mudando e refazendo teorias e hipóteses de trabalho.

No que diz respeito aos vestígios humanos, uma pergunta básica deve ser feita cada vez que materiais humanos são encontrados: esses vestígios provêm de um acúmulo natural (mortes acidentais) ou são eles o fruto de ações humanas (sepultamentos)?

É necessário responder a essa pergunta para se ter certeza no momento de interpretar os processos tafonômicos que podem ter ocorrido. Acúmulos naturais, assim como culturais, são importantes para a arqueologia, mas trazem informações diferentes. Assim, o estudo tafonômico de um acúmulo natural pode nos ensinar sobre o meio-ambiente de um sítio em um determinado momento, enquanto que o estudo de acúmulos culturais trará indícios sobre as atividades humanas que ocorreram em determinado local em uma dada época.

\subsubsection{Materiais e prática da tafonomia}

Para compreender a formação e a evolução dos vestígios arqueológicos, vários fatores devem ser analisados, o que obriga o arqueólogo a desenvolver conhecimentos fundamentais multidisciplinares (Bonnichsen, 1989a). Sendo assim, parte do trabalho do arqueólogo interessado em tafonomia passa por entender os vários subsistemas do planeta (atmosfera, clima, geologia, oceanografia, ecologia e cultura) e como estes se organizam entre si e afetam um ao outro (Bonnichsen, 1989a).

Alguns pesquisadores vão trabalhar a formação dos contextos arqueológicos (análises de paisagens, materiais fabricados, restos faunísticos, etc.) e as suas histórias (Binford, 1981), enquanto outros estudam a tafonomia aplicada a contextos funerários recentes ou antigos (Haglund e Sorg, 1997a e 1997b), ou à zooarqueologia (Lyman e Fox, 1997). Essas partes são complementares e necessárias para uma melhor compreensão da evolução dos remanescentes humanos em seus contextos. 
A identificação das alterações e dos agentes de mudança é importante para a compreensão de como um conjunto de vestígios se acumulou e como ele pode ter sido alterado (Andrews, 1995).

Duas citações de Mary E. Lewis no “The Bioarchaeology of Children” (2007) resumem a dificuldade de identificar os vários processos de preservação e decomposição:

- These studies [taphonomy] have shown that a complex interaction exists between many internal and external factors relating to the body and the burial environment. These will affect the rate and nature of soft- and hard-tissue decay (e.g. age and sex, presence of disease, open wounds, soil pH, temperature and burial depth). As each case is unique, it is impossible to make broad assumptions about the sequence of events during body decomposition. (Lewis, 2007, pg 23) ${ }^{10}$.

- As with soft-tissue decomposition, no single factor determines the level of bone preservation, and a complex relationship exists between a number of overlapping variables, both intrinsic and extrinsic. Intrinsic factors include the chemistry, size, shape, density, porosity and age of the bone, whereas extrinsic factors such as groundwater chemistry, clothing, soil type, temperature, oxygen levels, flora and fauna all play a role in diagenesis. In general, however, the decay of bone follows three phases: the chemical deterioration of the organic component, the chemical deterioration of the mineral component, and the microbiological attack of the composite form of the bone (Collins et al., 2002) (pg 24, Lewis, 2007). ${ }^{11}$

\footnotetext{
${ }^{10}$ Tradução da autora: Esses estudos [tafonômicos] mostraram que existe uma interação complexa entre muitos fatores internos e externos relacionados entre o corpo e o ambiente onde ocorreu o enterro. Esses vão afetar a velocidade e a natureza da decomposição dos tecidos duros e moles (ex. idade e sexo, presença de doenças, feridas abertas, acidez do solo, temperatura e profundidade da cova). Como cada caso é único, é impossível afirmações genéricas sobre a seqüência de eventos durante a decomposição do corpo.

${ }^{11}$ Tradução da autora: Como na decomposição dos tecidos moles, não é só um fator que determina a preservação de ossos, existe uma relação complexa entre várias variáveis sobrepostas, tanto intrínsecas como extrínsecas. Fatores intrínsecos incluem a química, o tamanho, a forma, a densidade, a porosidade e a idade do osso, enquanto que fatores extrínsecos como a química dos lençóis freáticos, a presença de roupas, o tipo de solo, a temperatura, o nível de oxigênio, a flora e a fauna, todos participam da diagenesis. Em geral, entretanto, a decomposição dos ossos segue três fases: deterioração química do componente orgânico, deterioração química do componente mineral, e ataque microbiológico da forma compósita do osso (Collins et al., 2002)” (pg 24, Lewis, 2007).
} 


\section{Identificação dos processos tafonômicos}

Dentre as várias observações tafonômicas que podem ser feitas sobre um conjunto de vestígios, citaremos algumas das mais freqüentemente mencionadas na literatura e que trazem informações sobre a utilização das ossadas, sobre as ocupações dos sítios e sobre os processos de decomposição:

- A morte e o corpo, o indivíduo (sexo, idade, estado de saúde, estrutura física) e a causa da morte influenciam a susceptibilidade dos restos humanos para serem afetados por fatores externos (Roksandic, 2002; Ubelaker, 1997, 1999). Ossos de indivíduos imaturos por muitas vezes não são encontrados ou são encontrados em péssimo estado de conservação por serem mais frágeis e mais vulneráveis a ações mecânicas. A robustez dos ossos os deixa mais ou menos aptos a suportarem ataques físicos e químicos do próprio solo. Doenças ósseas podem fragilizar todo ou parte do esqueleto.

- O ambiente no qual o sepultamento foi efetuado rege em grande parte como será a conservação do material ósseo. A umidade, a temperatura, a presença de oxigênio e mudanças climáticas contínuas causam impacto na estrutura dos ossos, desestabilizando-a (Haglund, 2002; Roksandic, 2002); Solos ácidos corroem mais rapidamente e de maneira mais intensa a estrutura dos ossos; A atividade de animais pode causar efeitos de perturbação e criar confusão na identificação de determinadas características observadas (como o tipo de marcas encontradas sobre os ossos); A atividade botânica é geralmente intensa, principalmente em zonas tropicais. As raízes das plantas são responsáveis por parte da corrosão causada aos ossos, pois liberam ácidos húmicos e penetram nos ossos quebrando-os (Dupras et al., 2006); “Weathering” (ou processo de intemperismo) é o conjunto de processos que afetam a conservação dos ossos (Behrensmeyer, 1978), principalmente quando expostos na superfície, mas não somente, e que provoca com o tempo a erosão, esfoliação e quebra dos ossos. O estado de decomposição/preservação dos ossos ajuda a identificar se ossos FRESCOS ou secos foram enterrados e como eles foram afetados pelos agentes físicos e químicos in situ (Behrensmeyer 1978 apud Lyman e Fox 1997);

- As ações humanas também são processos tafonômicos (Haglund, 2002; Sorg e Haglund, 2002). Elas podem ser intencionais, causando, às vezes, a morte, tratamentos pré-sepulcrais, tipo de cova e posição do corpo, como não intencionais por exemplo perturbações feitas no local onde estão enterrados os indivíduos. A 
cremação, por exemplo, causa grande impacto, quebrando os ossos e deixando-os mais frágeis; O estudo da relação dos ossos entre si permite verificar a posição deles e saber se há relações anatômicas podendo indicar uma decomposição in situ e a natureza cultural ou natural dos vestígios; A disposição do material ósseo no sítio (cemitério específico, enterramento em área de habitação, enterramento fortuito, acidente) deve ser reconhecida para que se possa compreender as perturbações e susceptibilidade à decomposição.

3.3 O estudo de contextos funerários e a formulação de hipóteses: como a arqueologia da morte e a tafonomia trazem respostas sobre as populações do passado

A maior parte dos estudos de tafonomia nos períodos pré-históricos recentes são feitos sobre os restos faunísticos deixados pelo homem, os quais serviram de fonte de alimentação e/ou matéria prima na maior parte das vezes (Kipnis, 2002); e também sobre os sepultamentos e como eles evoluíram e foram afetados pelos elementos naturais e/ou culturais (Duday, 2005; Masset, 1986; Roksandic, 2002; Sorg e Haglund, 2002). É a segunda aplicação que nos interessa no presente trabalho.

Dentro das análises de vestígios ósseos humanos entram os estudos de sepultamentos e de depósitos de corpos (sem intenção de sepultar). A análise feita pela antropologia forense ou arqueologia forense, de corpos recentemente enterrados ou abandonados permite reunir mais informações sobre os elementos da decomposição provenientes dos animais, do solo e das interferências humanas em geral (Haglund e Sorg, 1997a e 1997b).

Um corpo e seu local de deposição são estruturas fechadas, que devem ser analisados como um contexto específico. "Tanto pela perspectiva da tafonomia quanto pela ecologia, uma carcaça pode ser considerada como a peça principal de um novo micro-ambiente em desenvolvimento” (Kormondy e Brown, 1998 Apud Sorg e Haglund, 2002; Krebs, 1994 Apud Sorg e Haglund, 2002). Esse micro-ambiente interage com a biosfera, a litosfera e a atmosfera (Sorg e Haglund, 2002: 5). E ao mesmo tempo a conservação ou a deterioração dos ossos parecem estar ligadas mais ao micro-ambiente local do que a grandes zonas ecológicas (White e Hannus, 1983). 
Com o tempo, as fronteiras entre corpo e contexto vão se atenuando e estes dois elementos vão ficando cada vez mais envolvidos (Sorg e Haglund, 2002).

Além disso, há uma potencial permanente de interrelação entre vivos e mortos, o que nos obriga a considerar que, "durante todo o tempo de existência de um sítio funerário, deve ter havido intervenção humana sobre o local”' (Mendonça de Souza et al., 2001: 485-486). Há necessidade também de separar fatores pós-deposicionais através da identificação de evidênciais de erosões, compressões, quebras, queimas, incrustações, descolorações e outros - dos comportamentos funerários (Mendonça de Souza et al., 2001: 487).

- Os achados em um sítio arqueológico são sempre resultado da interação entre fatores bióticos, abióticos e antrópicos que alternam-se ao longo do tempo (Mendonça de Souza et al., 2001: 483).

Hoje em dia modelos tafonômicos utilizam teorias de alto, médio e baixo alcance (high, middle e low-range) ao mesmo tempo para compreender melhor os fenômenos envolvidos (Bonnichsen, 1989b). Eles têm como objetivo estruturar as informações para compreender o que aconteceu no passado. Esses diferentes níveis teóricos permitem uma melhor estruturação do pensamento e do conhecimento sobre as ações dos subsistemas terrestres nos ossos, isso tudo de forma hierárquica (Bonnichsen, 1989b) Ou seja:

- Most taphonomic models rely on assumptions from at least three different levels of organization and may seek explanations at each level. High-range theory, more commonly known as general systems theory, emphasizes understanding how the earth's subsystems operate together as a whole and explaining how linked subsystems affect one another. What occurs at the highest level affects what occurs at lower levels. Middle-range theory, as the name implies, focuses on the characterization of subsystem organization and explanations of how internal subsystem dynamics can produce change and how linkage with external subsystems can affect subsystem organization and operation. High-level statements about the organization and operational dynamics of environment and cultural subsystems also rely on what is here termed low-range theory. Low-range theory seeks to develop transformational statements linking pattern and process by using diagnostic morphological signatures. These signature characteristics may allow process inferences to be 
made about the operations of non-extant environment and cultural systems (Bonnichsen 1989b, pg. 517) ${ }^{12}$.

A arqueologia da morte, como sub-disciplina da arqueologia procura identificar os sepultamentos, as ações sobre os corpos e tudo que pode trazer informações sobre quem eram e como viviam as populações passadas. Enquanto isso, a tafonomia traz informações empíricas para a análise dos contextos. Não existe uma "receita de bolo" de quais processos vão afetar a conservação dos vestígios, nem com que intensidade ou hierarquia, mas utilizando analogias para a identificação de padrões podemos nos aproximar dos fatos ocorridos, em várias escalas diferentes (do micro ao macro). É nisso e na capacidade de distinguir processos naturais de processos culturais que a tafonomia mais auxilia a arqueologia. Quando consideramos que os processos tafonômicos estão presentes em tudo e não somente em sepultamentos, podemos extrapolar a aplicação da tafonomia forense fazendo diversas inferências mesmo em contextos não funerários (por exemplo, como uma casa se decompôs, análise de estruturas construídas, etc.). Partimos com essas premissas e afirmações para compreender o sítio Hatahara e seus sepultamentos.

\footnotetext{
${ }^{12}$ Tradução da autora: A maioria dos modelos tafonômicos se baseia em pressupostos de organização de pelo menos três níveis e podem procurar explicações em cada nível. Teorias de alto alcance, mais conhecidas como teorias de sistemas gerais, enfatizam a compreensão de como os sub-sistemas da terra operam juntos como um todo e explicam como sub-sistemas ligados afetam uns aos outros. 0 que acontece no nível mais alto afeta o que ocorre nos níveis mais baixos. Teorias de médio alcance, como o nome indica, foca na caracterização da organização de sub-sistemas e explicações de como a dinâmica interna de um sub-sistema pode produzir mudanças e como essa ligação com sub-sistemas externos podem afetar a organização e funcionamento dos sub-sistemas. Afirmações de alto nível sobre a organização e funcionamento das dinâmicas de sub-sistemas ambientais e culturais também se fundamenta no que aqui chamamos de teorias de baixo alcance. Teorias de baixo alcance procuram desenvolver afirmações transformacionais ligando padrões e processos pela utilização de assinaturas morfológicas diagnósticas. As características dessas assinaturas podem permitir inferências sobre processos de serem feitas sobre a operação de sistemas ambientais e culturais extintos (Bonnichsen, 1989b, pg. 517).
} 


\section{MÉTODOS}

A abordagem de pesquisa seguida nesse trabalho se baseia em metodologias utilizadas em estudos sobre a arqueologia da morte e a tafonomia. Ao mesmo tempo em que busca identificar processos e padrões, esta abordagem admite uma grande variabilidade de situações, o que permite aplicá-la em contextos complexos. Tendo sido desenvolvida para contextos culturais, cronológicos, geográficos e ambientais diversos dos encontrados no Brasil, os métodos precisaram ser adaptados às necessidades específicas desta pesquisa.

Para a realização dessa dissertação foram utilizados dados produzidos a partir de dois conjuntos de materiais em condições de análise distintas a saber:

1.- materiais escavados a partir de 2006, para os quais foi possível seguir todas as etapas de campo estipuladas no protocolo (Sepultamento XIV a XXVIII);

2.- materiais oriundos de escavações mais antigas, para os quais as etapas previstas no protocolo de análise de campo tiveram que ser reconstituídas a partir do registro documental (relatórios, fichas, fotos e croquis) (Sepultamento I a XIII).

Neste caso, algumas informações não puderam ser recuperadas, o que está sinalizado nas descrições. As maiores heterogeneidades de dados quando comparados os materiais escavados antes e depois de 2006 provêm das interpretações de processos tafonômicos e tipos de sepultamento.

Para apresentar os métodos empregados nesse trabalho, esta seção será dividida em duas partes: primeiro os métodos utilizados em campo e posteriormente aqueles utilizados nos trabalhos em laboratório.

\subsection{Metodologia aplicada à análise de sepultamentos em campo}

Para tentar amenizar os impactos do campo e retirar o máximo de informações dos restos humanos encontrados, os sepultamentos foram, sempre que possível, desmontados em campo ou em "pequenos blocos" por parte anatômica ou concentração de ossos muito fragmentados. Isso permitiu uma melhor visualização em campo, pois sabíamos exatamente onde começavam e onde terminavam os sepultamentos e assim suas relações com as camadas arqueológicas que já eram conhecidas. 
Entretanto, em alguns casos os sepultamentos tiveram que ser retirados em bloco, quando o tempo de escavação ou a falta de pessoas experientes para as escavações e desmontagem se fazia sentir.

Os ossos recolhidos geralmente recebiam números individuais desde o campo, mas alguns blocos foram retirados, por exemplo para mãos, pés, costelas, etc., nesse caso dependendo da situação os ossos receberam numeração individual ou não. A seleção se fez de acordo com a importância tafonômica do conjunto de ossos em questão. Por exemplo: o bloco de ossos de ambos os pés do sepultamento XIX, não foi desmontado em laboratório (por enquanto), mas os ossos do tarso, do metatarso e as falanges foram numerados individualmente em croqui. Enquanto isso as costelas retiradas em blocos não foram numeradas individualmente, pois o processo tafonômico envolvido era de um “affaissement” (abaixamento).

Para escavação dos sepultamentos um protocolo de observações e análises foi elaborado a partir das propostas de diversos autores Duday (2005), Dupras et al. (2006), Haglund (2002), Roksandic (2002), Sorg e Haglund (2002), Ubelaker (1999). Esse protocolo foi desenvolvido seguindo as etapas de de trabalho, começando pela delimitação da cova, que pode ser feito pela diferenciação de textura, cor e conteúdo. Isso permite reconhecer o espaço que foi impactado e reconhecer sobreposições de covas se perturbando. Se os limites não estiverem visíveis (ou perceptíveis), é necessário delimitar o espaço ocupado pelo esqueleto (medindo dois eixos ortogonais de maior extensão). Durante a escavação dos sepultamentos as unidades de escavação não devem ser seguidas, pois elas são arbitrárias, enquanto que o sepultamento representa um gesto único e contido no tempo.

É necessário expor o máximo de ossos e articulações possíveis, sem quebrá-los ou fragilizá-los - criando um efeito flutuação. A exposição dos ossos permite que as relações entre eles fiquem evidentes, tanto a posição anatômica quanto a sobreposição de ossos. O resultado dessa exposição deve ser amplamente registrado, por fotos, croquis e descrições. O registro fotográfico deve conter fotos do sepultamento inteiro, dos detalhes das articulações e/ou associações e fotos gerais de contextualização.

As descrições e os croquis são essenciais para o registro dos sepultamentos. Esses dois elementos completam as fotos deixando mais clara a observação dos processos tafonômicos e de decomposição. Para isso deve-se identificar o máximo de elementos ósseos (por comparação com desenhos e fotos em livros de anatomia e/ou 
osteologia (Abrahams et al., 1998; Buikstra e Ubelaker, 1994; White e Folkens, 2000); descrever as articulações, que de acordo com Duday (2005) permitem conhecer os movimentos naturais (decomposição) e as perturbações (humanas, animais e botânicas) dos ossos. As articulações entre os ossos podem ser classificadas em: estritas (quando não há espaço entre os ossos e que eles estão em posição anatômica); quase-estritas (quando há presença de leves torções ou deslocamentos, de até aproximadamente $1 \mathrm{~cm}$, entre ossos que se articulam); soltas (quando há proximidade entre as extremidades que se articulam, mas há distanciamento e torções de aproximadamente $90^{\circ}$ graus ou mais); sem articulação (no caso de ossos que não se articulam diretamente, por exemplo as costelas: o fato de ossos estarem ou não na posição anatômica também são indícios de movimentos). No caso de sepultamentos secundários anotar a organização dos ossos (em feixe, posição do crânio, etc.). A identificação das faces de aparição dos ossos, em relação ao plano anatômico permite verificar a natureza dos giros, torções e inversões dos ossos.

Desde o campo deve-se estimar o número mínimo de indivíduos e se possível a idade e o sexo. Medidas devem ser tiradas por precaução, pois é freqüente que os ossos se quebrem no transporte do campo para o laboratório. Essas informações retiradas em campo só devem ser usadas caso os ossos não se preservem até o momento da análise em laboratório. Dentro dos limites são aplicados os mesmos métodos que no laboratório.

A interpretação da posição original de deposição do corpo ou ossos, antes da decomposição e/ou perturbações humanas ou naturais pode ser feita através: da identificação dos processos de decomposição e instabilidades na posição dos ossos, pois o desaparecimento das partes moles (e por vezes partes duras) movimenta os ossos e pode causar desmoronamentos (ex. as costelas); dos limites das covas que por muitas vezes não são perceptíveis ou não correspondem aos limites do corpo; a identificação dos efeitos de delimitação (efeito de parede) do corpo através da verificação de ossos em posições instáveis ou "limitados” (não ultrapassando uma fronteira hoje em dia inexistente) podem indicar limites criados por materiais perecíveis (madeira, palha, etc.); da identificação do tipo de preenchimento da cova (rápido, lento, progressivo, diferenciado) pode-se estimar a granulometria do sedimento ao redor (areia, argila, silte), a existência de elementos interposantes (pedras, caixão, etc.), a presença de meio líquido, etc. 
É necessário identificar os processos tafonômicos que causam alterações na forma das covas, nos sepultamentos, na posição dos ossos e na conservação dos mesmos. Os fatores tafonômicos podem ser: internos (tipo de morte e estado do corpo), identificáveis por marcas nas estruturas ósseas, como fraturas de defesa na ulna (Larsen, 2000), e alguns tipos de patologias ósseas que causam grande porosidade da estrutura óssea; externos (weathering, o sistema de cotação de Behrensmeyer (1978) deve ser utilizado como base - 0 sendo o osso sem alterações e 5 o osso esfarelando e craquelando), características do solo, atividades humanas, atividades botânicas, ambiente no momento do enterramento e evolução até o presente. Esses fatores deixam marcas nos elementos ósseos (quebras, impressões por acidez, presença de raízes, etc.); ou de ação humana, tratamento pré-sepulcral (descarnamento, cremação), tipo de sepultamento (primário ou secundário), perturbações (reutilização do espaço evidente por buracos de postes ou estruturas sobrepostas), causa da morte, efeitos de “arrumação” (por exemplo, sepultamentos secundários geralmente são organizados de acordo com o tamanho dos ossos). Abaixo segue uma tabela (2) com os principais fatores tafonômicos:

Tabela 2: resumindo os processos a serem observados e seus significados

\begin{tabular}{|l|l|l|}
\hline Tipo de processos & $\begin{array}{l}\text { Características a serem } \\
\text { observadas }\end{array}$ & Descrição das características \\
\hline $\begin{array}{l}\text { Fatores tafonômicos } \\
\text { internos }\end{array}$ & Morte & $\begin{array}{l}\text { Causa da morte. Mortes violentas podem } \\
\text { deixar marcas nos ossos (fraturas de defesa, } \\
\text { presença de corpos estranhos - pontas de } \\
\text { flecha, balas). }\end{array}$ \\
\hline $\begin{array}{l}\text { Fatores tafonômicos } \\
\text { externos }\end{array}$ & $\begin{array}{l}\text { Estado do corpo no momento da morte, idade, } \\
\text { sexo, corpulência, patologias. }\end{array}$ \\
\hline "Decomposição" \\
& Solo & $\begin{array}{l}\text { Descoloração, manchas, erosão, rachaduras, } \\
\text { descascamento, craquelamento (tabela de } \\
\text { Behrensmeyer, 1978). }\end{array}$ \\
\hline & $\begin{array}{l}\text { Acidez, umidade, drenagem, compactação, } \\
\text { granulosidade e tipo de sedimento, } \\
\text { contaminantes. Todos esses elementos alteram } \\
\text { as estruturas externas e internas dos ossos, } \\
\text { deixando-os mais frágeis. }\end{array}$ \\
\hline & Atividade de animais & $\begin{array}{l}\text { Marcas de dentes de roedores, de carnívoros, } \\
\text { de remexedores de terra (ex. tatu). } \\
\text { Ácido húmico (marcas sinuosas nos ossos), } \\
\text { atividade mecânica (raízes quebrando os ossos } \\
\text { de dentro para fora). }\end{array}$ \\
\hline & Ambiente & $\begin{array}{l}\text { Temperatura antes do enterramento (a } \\
\text { decomposição é acelerada por temperaturas } \\
\text { altas), umidade (quanto maior a umidade }\end{array}$ \\
\hline
\end{tabular}




\begin{tabular}{|l|l|l|}
\hline & Tratamento pré-sepulcral & $\begin{array}{l}\text { maior o número de micro-organismos), } \\
\text { exposição do corpo à atmosfera após enterro, } \\
\text { presença de oxigênio (sem oxigênio as } \\
\text { bactérias não se proliferam). }\end{array}$ \\
\hline Ação humana & $\begin{array}{l}\text { Traços de corte e/ou queima. Os traços de } \\
\text { corte estão freqüentemente perto das } \\
\text { articulações nas inserções musculares. } \\
\text { efeito da queima no osso indica se esta } \\
\text { acontece com ele ainda fresco (úmido) ou } \\
\text { seco. }\end{array}$ \\
\hline & Tipo de sepultamento & $\begin{array}{l}\text { Profundidade (sepultamentos rasos são mais } \\
\text { afetados pelas perturbações animais e } \\
\text { humanas), compactação, inclusões, } \\
\text { preenchimento. }\end{array}$ \\
\hline & Causa da morte & $\begin{array}{l}\text { Rituais, guerras, assassinatos, canibalismo } \\
\text { (presença de objetos e estranhos e tipos de } \\
\text { covas, por exemplo mass graves). }\end{array}$ \\
\hline Perturbações & $\begin{array}{l}\text { Reocupações do local, longevidade do } \\
\text { cemitério, re-estruturação do espaço podem } \\
\text { causar danos nos ossos e deslocamento. }\end{array}$ \\
\hline
\end{tabular}

Dados fornecidos pelos seguintes autores: Dupras et al., 2006; Haglund, 2002; Roksandic, 2002; Sorg e Haglund, 2002; Ubelaker, 1999.

Além da análise do sepultamento e dos ossos deve-se verificar se há materiais associados (como fragmentos cerâmicos, líticos, fauna, etc.). Os materiais associados podem revelar algum tipo de preparação específica e fornecer uma data relativa importante de quando aconteceu o enterro.

Após as análises de contexto, pode-se começar a desmontagem do sepultamento elemento ósseo por elemento ósseo ou em pequenos blocos de conjunto anatômico (ex. mãos ou pés), o que permite compreender a posição de cada elemento e como eles evoluíram no tempo. Cada osso plotado recebe um número individual e, dependendo da situação, medidas de profundidade da base de cada elemento são necessárias. No caso específico do material estudado, que é resultado de vários anos de escavação com objetivos e metodologias diferentes, houve certa dificuldade para determinar as profundidades de alguns sepultamentos (várias profundidades foram anotadas). Optou-se por trabalhar com as medidas a partir do DATUM geral do sítio, que foram apresentadas em algumas plantas baixas (ver figura 4) para o material recolhido até 2002, ignorando as profundidades anotadas nas fichas de escavação. O material recolhido no montículo I a partir de 2006 está todo referenciado a partir do DATUM do sítio. Para os sepultamentos onde não foi possível determinar a 
profundidade com precisão, em relação ao DATUM do sítio, trabalhou-se por camadas.

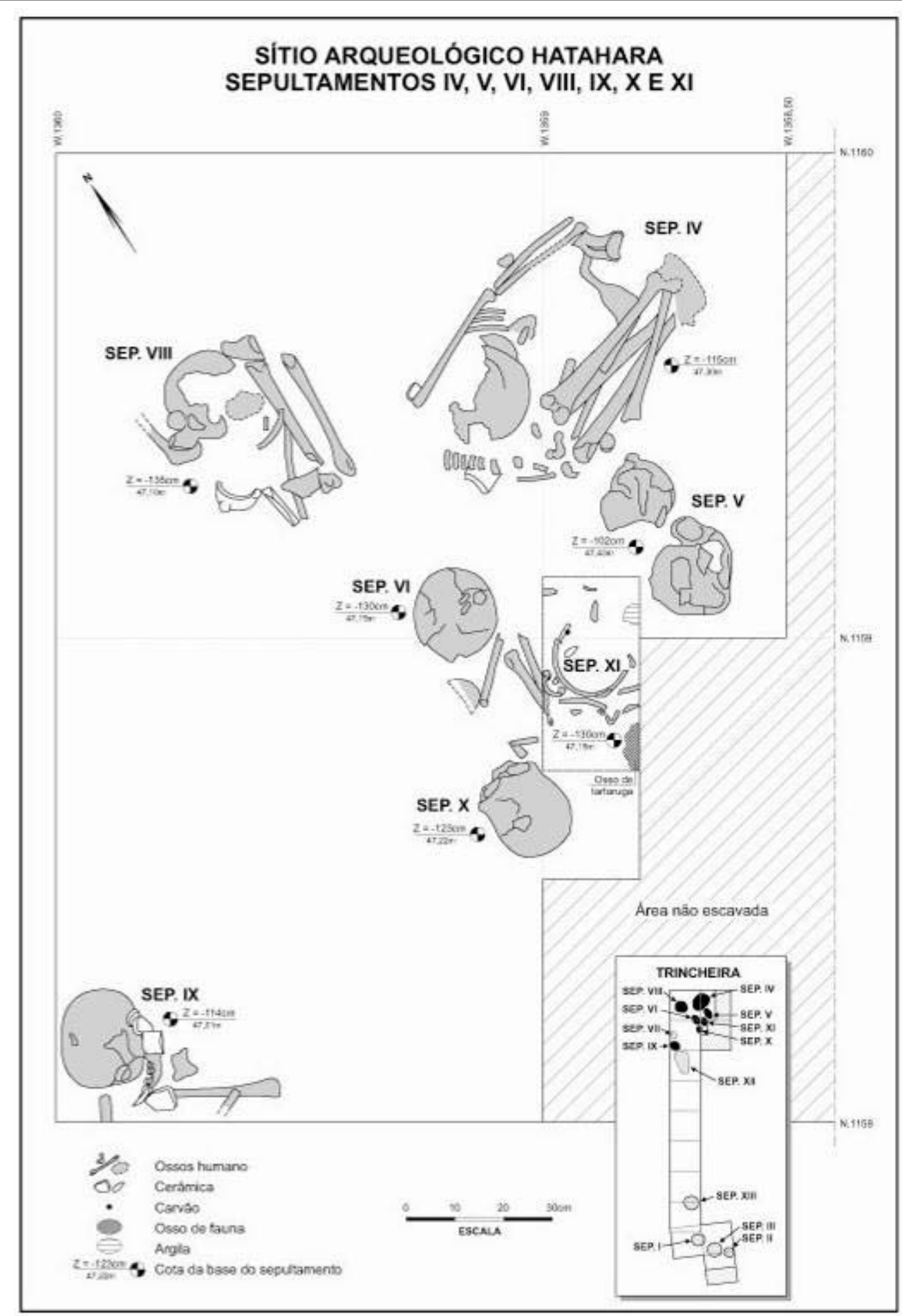

Figura 4: onde há a cota da base do sepultamento, levou-se em conta somente o número de baixo (ex. 47,22m) que está relacionado ao DATUM do Sítio. Fonte: PAC 
Por fim os ossos devem ser acondicionados o melhor possível para evitar quebras. Várias etapas de desmontagem são geralmente necessárias, o que implica em várias etapas de limpeza e análise.

Protocolo de escavação e análise de sepultamentos

Definido a partir de Buikstra e Ubelaker (1994) Duday (2005), Dupras et al. (2006), Haglund (2002), Rocksandic (2002), Sorg e Haglund (2002), Ubelaker (1999)

1. Delimitação aproximada da cova:

a. Sepultamentos trabalhados como entidades inteiras

2. Expor o máximo de osso e articulações possíveis

3. Registro fotográfico e desenho

a. Do sepultamento

b. Dos detalhes das articulações e/ou associações de ossos

c. Fotos amplas para contextualização

d. Desenho geral mostrando todos os elementos ósseos visíveis

4. Descrever a posição de todos os elementos ósseos e suas relações

a. Descrição da relação anatômica geral e detalhada

i. Identificação dos elementos ósseos

ii. Descrição das articulações: estritas, quase-estritas, soltas, sem articulação

iii. Descrever relação entre ossos que não se articulam (ex. costelas)

b. Estimar o número mínimo de indivíduos

c. Estimar sexo e idade, se a preservação permitir

d. Identificar face de aparição dos ossos

5. Medir todos os ossos in situ

6. Interpretação da posição original de deposição do corpo ou ossos

a. Identificar processos de decomposição e instabilidades criadas

b. Identificar efeitos de delimitação (efeito de parede)

c. Identificar tipo de preenchimento da cova (rápido, lento, progressivo, diferenciado):

7. Identificação dos processos tafonômicos

a. Fatores tafonômicos Internos

b. Fatores tafonômicos externos

c. Ação humana

8. Descrição do material associado

9. Desmontagem do sepultamento elemento ósseo por elemento ósseo

a. Atribuição de número individual por elemento

b. Medir a profundidade da base do osso

10. Acondicionamento

11. No caso de sepultamentos secundários ou primários restritos, onde freqüentemente há uma grande sobreposição dos elementos ósseos, todas as etapas de 2 a 10 devem ser repetidas. 
A aplicação desse protocolo está intimamente ligada à conservação dos vestígios humanos, portanto visto o estado do material oriundo do sítio Hatahara muitas informações não puderam ser retiradas.

\subsection{O laboratório}

Em 2001 o material escavado em 1999 foi analisado, limpo e acondicionado por Rafael Bartolomucci (na época mestrando do Museu de Arqueologia e Etnologia da USP), e os dados apresentados por Machado (2005) provêm de seu trabalho. Não tivemos acesso às fichas ou descrições, vimos somente o que foi apresentado por Machado.

Aparentemente esse mesmo material e alguns elementos provenientes da escavação de 2001 foram revistos por Cláudia Plens (Machado, 2005) e Verônica Wesolowski (Machado, 2005), mas de acordo com as pesquisadoras o intuito dessa revisão foi auxiliar Machado a completar seus dados e não foram feitas análises detalhadas.

Para essa etapa de laboratório utilizou-se bibliografias de apoio específicas. Os ossos foram identificados por comparação com desenhos, fotos e descrições presentes nos livros de anatomia (Abrahams et al, 1998), de osteologia (White e Folkens, 2000) e manuais de bioarqueologia (Buikstra e Ubelaker, 1994; Bass, 1995). Para identificar os dentes, as lesões dentárias e descrever algumas características epigeneticas utilizamos: Scott e Turner 1997; Hillson, 1996; Buikstra e Ubelaker, 1994; Wesolowski, 2007.

Antes de decidir quais métodos seriam aplicados fez-se um levantamento de quais seriam os mais adaptados para o material. Durante os estudos sobre estimativa de idade percebeu-se a quantidade de imprecisões que ainda existem nos métodos usualmente aplicados (Schmitt, 2005), principalmente para adultos. As análises mais precisas que encontradas utilizam estatística baesiana (Schmitt, 2005) sobre várias características da pelve, previamente definidas por Lovejoy et al, em 1985 (apud Buikstra e Ubelaker, 1994), mas analisadas com um sistema de cotação diferente (Schmitt, 2005). Porém, visto o estado de conservação das pélvis encontradas, não era possível analisar essas características na sua maioria. As suturas cranianas foram vistas, mas a conservação não permitiu um estudo detalhado. Entretanto não 
podíamos deixar de tentar nos aproximar de uma idade para os esqueletos estudados, mesmo que ela não seja muito precisa. Assim, decidimos utilizar cinco grandes classes etárias: Adulto Maduro acima de 40 anos; Adulto 25-40 anos; Adulto Jovem entre 18-25 anos; Sub-adulto 14-17 anos; Infantil: abaixo de 14 anos. Para chegarmos nessas categorias vários critérios foram utilizados sozinhos e/ou simultaneamente dependendo da faixa etária e da conservação do material ósseo. Para os indivíduos infantis os métodos de análise de erupção dentária (Buikstra e Ubelaker 1994; usando Scheuer e Black, 2000, quando dúvidas persistiam), de fusão das epífises nos ossos do pós-crânio (Scheuer e Black, 2000; Birkner, 1980) e de tamanho dos ossos de criança (Scheuer e Black, 2000) foram utilizados.

Como esperado a estimativa etária dos indivíduos adultos é uma aitividade muito mais delicada e imprecisa. Dois grandes tipos de análise foram feitas: uma sobre os dentes, o cálculo de desgaste foi feito a partir dos métodos de Scott e Smith apresentados por Buikstra e Ubelaker (1994) e Hillson (1996); e em raras oportunidades os métodos de análise da superfície da sínfise pubiana e da superfície auricular apresentados por Buikstra e Ubelaker (1994).

Quanto à identificação de patologias e de deformidades ósseas, elas não foram muito detalhadas, pois a conservação nem sempre permitia ter certeza. Para os casos mais fáceis e visíveis macroscopicamente foi utilizado como referência Buikstra e Ubelaker (1994) e o manual de White e Folkens (2000).

Para estimativa do sexo dos indivíduos, a metodologia de Bruzek (1991) foi empregada para as pélvis conservadas. No entanto, houveram pouquíssimas oportunidades de utilizar esse método. A fiabilidade da determinação sexual pelo crânio é atestadamente mais incerta (Bruzek, 1991), mas ainda assim tentou-se algumas estimativas utilizando os métodos apresentados por Buikstra e Ubelaker (1994). Entretanto, como não existem coleções de comparação, os resultados devem ser entendidos como possibilidades. Quando o crânio estava mal conservado, fato que ocorreu a maior parte das vezes, os ossos do pós-crânio foram descritos como robustos ou gráceis quando necessário, mas de forma alguma tentamos determinar o sexo a partir deles.

Como para o campo um protocolo foi seguido em laboratório, e as informações recolhidas através de fichas (ver anexo 4). As fichas utilizadas em campo foram as mesmas usadas em laboratório para as análises gerais, sendo que item 
“observação” mais descrições foram dadas sobre o estado dos ossos. Além dessas fichas, também foram usadas fichas específicas para análise das arcadas dentárias, baseadas em Wesolowski (2007), mas as análises sobre os dentes foram limitadas no presente projeto.

O protocolo elaborado para o laboratório foi definido a partir dos trabalhos de Buikstra e Ubelaker (1994), Hillson (1996) e White e Folkens (2000). A primeira etapa laboratorial consiste em limpar o material. Visto a fragilidade optou-se pela limpeza a seco com auxílio dos instrumentos de dentista e/ou pouca água. No caso dos dentes, e alguns elementos onde a terra atrapalha demasiadamente a leitura, a limpeza foi feita com água e algodão - deixando uma amostra sem lavar, no caso dos dentes, se houverem cálculos dentários.

Em seguida faz-se uma confirmação das identificações feitas em campo: dos elementos esqueletais; da presença de elementos patogênicos; da presença de corpos estranhos; constatando se há calos ósseos ou deformações, etc. Com o material limpo é mais fácil identificar se houve intervenção humana (como marcas de corte). Em laboratório, todas as análises estimando sexo e idade devem ser verificadas, assim como as medidas dos ossos para determinar o seu tamanho - no presente trabalho não foi possível trabalhar com osteometria, porque raríssimos foram os ossos íntegros o suficiente para esse tipo de análise.

Em sepultamentos contendo vários indivíduos é necessário determinar o número mínimo de indivíduos através da contagem de elementos repetidos, da idade óssea, tamanho e morfologia dos ossos. Associar, o máximo possível, os elementos ósseos de um mesmo indivíduo é necessário para que se possa fazer as análises mencionadas anteriormente.

Como no campo o registro fotográfico é indispensável, no presente trabalho ele foi feito para os ossos identificáveis e/ou fragmentos acima de 1cm. Logo após há necessidade de acondicionar o material de forma permanente, separando as amostras para análises químicas e físicas, utilizando material neutro, se possível. A manipulação deve ser feito, preferencialmente com luva sem amido e com máscaras. 


\section{Protocolo de laboratório}

Definido a partir de Buikstra e Ubelaker, 1994, Hillson, 1996,

White e Folkens, 2000

\section{Limpeza a seco}

a. No caso de dentes, e alguns elementos onde a terra atrapalhava demasiadamente a leitura, a limpeza foi feita com água e algodão deixando uma amostra sem lavar no caso dos dentes, principalmente se houverem cálculos;

2. Confirmação das análises preliminares feitas em campo:

a. Identificação dos elementos esqueletais presentes;

b. Análise detalhada de elementos patogênicos, presença de corpos estranhos, formação de caries e cálculos, calos ósseos, deformações, etc.;

c. Identificar evidências de intervenções humanas (ex. marcas de corte);

3. Estimativa de sexo e idade (Bruzek, 1991; Buikstra e Ubelaker, 1994);

4. Medidas dos ossos:

a. Três medidas para determinar o tamanho do osso;

5. No caso de sepultamentos múltiplos:

a. Determinar o número mínimo de indivíduos através da contagem de elementos repetidos, da idade óssea, tamanho e morfologia dos ossos;

b. Pariar: Associar os elementos pertencentes a cada indivíduo, quando possível.

6. Registro fotográfico de todos os ossos identificáveis e/ou acima de $1 \mathrm{~cm}$

7. Acondicionamento permanente

a. Separar amostras para análises químicas e físicas;

b. Utilização de material neutro, se possível;

c. Manipulação com luvas sem amido ou manipulação direta;

d. Utilização de máscaras durante a manipulação em laboratório.

\subsection{Metodologia aplicada à reconstituição do material ósseo}

Durante a análise do material fizemos a opção de limitar a consolidação e a colagem do material. Essa decisão se deu por várias razões:

Em primeiro lugar, a fragmentação dos ossos era tal que as colagens só poderiam ser parciais e não trariam informações significativas, principalmente para o material coletado em 2006. A consolidação e colagem foram feitas em casos indispensáveis (ex: pelve do Sepultamento VIII), onde a remontagem poderia trazer precisões quanto à idade, sexo ou patologia do indivíduo.

A maior parte dos ossos fragmentados não apresentava superfícies de quebra definidas. A colagem nesse caso seria interpretativa ou no mais meramente estética. 
Ossos longos geralmente utilizados para medidas estavam todos (com exceção de algumas falanges) sem uma ou ambas as extremidades, a maioria estando sem ambas e estavam na maior parte das vezes incompletos.

Várias análises químicas estão sendo realizadas no material e a presença de consolidantes e/ou cola atrapalha os resultados. Análises de isótopos (Carbono e Nitrogênio) serão realizadas por Tiago Hermenegildo na Universidade de Cambridge, enquanto que outras amostras estão sendo enviadas ao Laboratório Beta Analytics para datação. É necessário manter uma grande porção do esqueleto sem contaminação, pois as análises estão exigindo muito material e por várias vezes elas não funcionaram e serão refeitas.

Aplicação de consolidantes foi efetuada com auxílio de Sílvia Cunha Lima, conservadora chefe do Museu de Arqueologia e Etnologia da USP e Verônica Wesolowski, doutora pela FIOCRUZ. Como o material apresentou resposta variável à consolidação, vários tipos de consolidante com concentrações diferentes foram experimentados. Para imersão do material seco utilizamos paraloide concentrado a 15\%. Para consolidação durante e após a escavação o mais indicado foi Primal a 15\%. Em caso de decomposição avançada, utilizou-se uma concentração de Primal a 5\% só para manter alguma integridade dos ossos durante a escavação.

\subsection{Definições utilizadas}

É importante especificar alguns dos termos a serem utilizados nesse trabalho, evitando assim confusões ou más interpretações. Essa terminologia estruturou as descrições e opções metodológicas desse trabalho, mesmo quando todos os termos não foram utilizados. Estamos usando as definições apresentadas por Duday (2005), exceto o conceito “d” que foi definido com base nos trabalhos apresentados por Haglund e Sorg (1997b):

a) Foi considerado como sepultamento onde percebia-se intenção. Para que um corpo ou elementos sejam considerados como sepultamento é necessário que haja intencionalidade da parte dos vivos de enterrá-lo. Nesse caso o sepultamento faz parte de um ritual, mesmo que este seja muito breve. 
b) Os sepultamentos primários foram identificados a partir das relações anatômicas entre os ossos, onde foi possível determinar que a decomposição das partes moles aconteceram in situ.

c) Enquanto que os sepultamentos secundários são enterramentos de ossos “secos”, onde não há (ou há pouca) organização anatômica, mas onde a presença de uma organização é evidente (ex. ossos longos em feixe com crânio por cima). O enterramento definitivo é precedido de uma fase de decomposição ou descarnamento das partes “moles” que acontece em geral em um local de transição. Portanto o corpo do indivíduo é tratado antes de ser enterrado definitivamente. Não associa-se o status do indivíduo aos termos de primário e secundário.

d) Foi tratado como depósito os restos humanos dispersos sem organização. Os depósitos podem ser divididos em duas categorias: o depósito primário que é fruto de um ato intencional. Esse gesto não é ligado a rituais funerários, geralmente essa ação está ligada a reorganizações de cemitérios e ou sepultamentos; o depósito secundário provém de um gesto não intencional. Assim os restos podem ser enviados para outro local, sem que esse tenha sido o objetivo da ação. O transporte dos restos é um resultado secundário e não o objetivo do transporte, podendo nem ser percebido pelo autor.

e) Os sepultamentos colocados diretamente na terra ("en pleine terre/ espace colmaté”) são geralmente distinguíveis pelo posicionamento de ossos em posições de “desequilíbrio”.

f) Quando existe um material entre o corpo (ou ossos) e a terra, o sepultamento é considerado como indireto. Se o elemento for orgânico ele pode se decompor após as partes moles criando espaços vazios importantes e permitindo que ocorra movimentação dos ossos.

g) O tipo de preenchimento das covas por terra pode ser: progressivo ou “colmatage progressif”, onde o espaço vazio criado pela desaparição das partes “moles” do corpo é preenchido imediatamente, não permitindo que haja movimentação dos ossos ou outros elementos. De acordo com o desaparecimento das partes, o sedimento toma seu lugar em seguida, impedindo que ossos em posições instáveis caiam (ex: quando a patela fica 
sobre o fêmur); ou lento ou ("colmatage differé”), quando o preenchimento do espaço vazio criado pela desaparição das partes “moles” do corpo não é imediato, permitindo que haja movimentação dos ossos ou outros elementos.

h) Identificou-se "efeito de parede ou effet de paroi" quando um elemento se encontrava mantido em situação instável, porque ele se apóia (ou apoiava) em uma estrutura impedindo a sua queda. Não está necessariamente relacionado à presença de uma parede e sim de “algo” que mantém o osso ou outro elemento em sua posição (parede, terra, limites de cova, etc.)

i) Dentro de um sepultamento há dois tipos de espaços vazios: o original $\mathrm{X}$ secundário. O primeiro está relacionado ao espaço que fica "não preenchido” no momento do enterramento, enquanto que o segundo tipo de espaço está relacionado ao espaço vazio que é criado pelo desaparecimento da arquitetura da cova ou de elementos funerários. A presença desses espaços explica em grande parte as movimentações de ossos vistas nos sepultamentos.

j) Foi possível identificar efeitos de restrição ou de compressão sobre o corpo. Esse efeito é visível em algumas articulações do corpo (posição das clavículas, dos coxais, dos pés, das mãos, das costelas) que demonstram que algum elemento diminuiu o espaço de decomposição do corpo, comprimindo-o (ex: saco ou amarração).

k) Para identificar a posição do corpo dentro da cova, levou-se em conta a posição da coluna, das pernas, dos braços e do crânio. Decúbito dorsal: indivíduo de costas; decúbito lateral: indivíduo de lado; pernas fletidas: pernas dobradas. 


\section{RESULTADOS}

Aqui se encontram os dados obtidos em campo e em laboratório através da aplicação dos protocolos apresentados na parte de MÉTODOS, alguns resultados gerais sobre o que foi encontrado durante as escavações foram mencionados na seção SÍTIO HATAHARA. Visto os objetivos do trabalho foi dada ênfase à etapa de campo e ao estudo do enterramento como estrutura fechada, ou seja, representando uma única ação (Duday, 2005). A quantidade de informação obtida para cada sepultamento está relacionada a vários fatores, dentre eles a conservação e a época de escavação. Como mencionado anteriormente tentou-se paliar as diferenças através dos diversos registros (foto, croqui, fichas, cadernos de campo e relatórios).

Como apresentado na parte de INTRODUÇÃO, serão descritos os sepultamentos em montículos, sendo um em urna. Com a exceção do sepultamento I, todos são considerados como pertencentes à fase Paredão, isso se dá pelas datações diretas feitas em 14C e pelo contexto - o material associado, a estratigrafia e o contexto monticular - indicam que as populações vivendo durante essa fase foram responsáveis por esses vestígios.

No intuito de facilitar a compreensão, a apresentação de cada sepultamento se fará de forma independente, onde serão apresentadas as informações disponíveis de campo e de laboratório. No próximo capítulo, DISCUSSÃO, os resultados serão discutidos a luz do conhecimento atual e serão levantadas algumas hipóteses sobre a formação desses contextos e de sua preservação em solo Amazônico. Em anexo (5 e 6) estão: uma planta baixa dos sepultamentos do montículo I; as suas relações de profundidade dos sepultamentos no mesmo montículo.

\section{SEPULTAMENTO I}

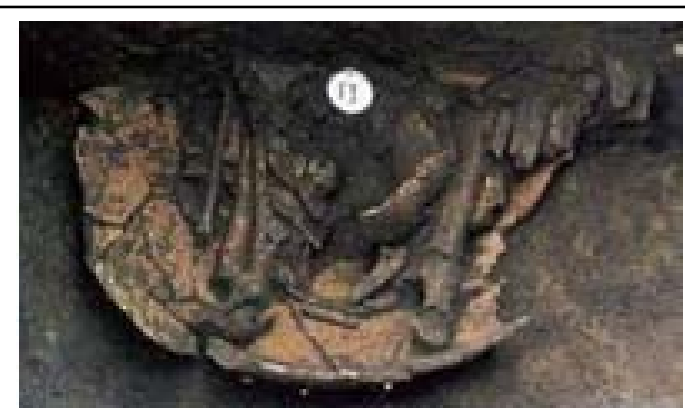

As informações de campo para

Figura 5: Foto do sepultamento I. Fonte: PAC. 


\section{1- Localização}

Esse sepultamento foi encontrado na primeira etapa de campo no Hatahara, em 1999, inicialmente chamado de feição 1 (F1). Ele estava situado entre as unidades: N1152W1359

e

N1152W1360 (ver figuras 5 e 6$)$.

De acordo com as fichas, esse sepultamento teria começado a aparecer a partir dos $98 \mathrm{~cm}$ de profundidade dentro de uma urna funerária, na quadra N1152W1360,

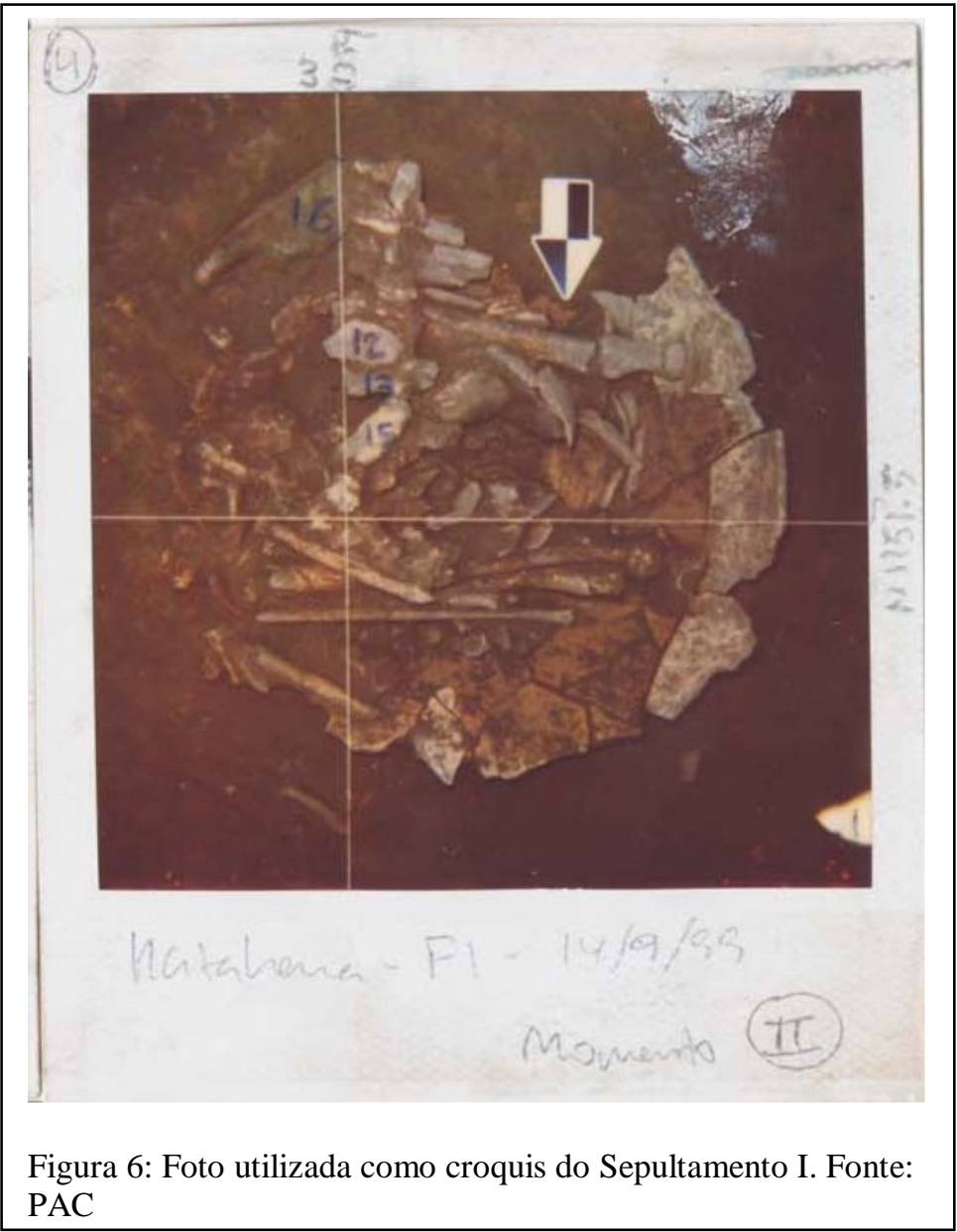
mas que a maior parte dos elementos ósseos estão entre $120 \mathrm{~cm}$ e $137 \mathrm{~cm}$. A base da urna estava a $140 \mathrm{~cm}$ de profundidade. Para esse sepultamento houve certa dificuldade para identificar o seu DATUM. Mas percebe-se que é um enterramento profundo pelas próprias fotos (ver figura 7), Machado (2005) relata que ele está muito próximo à camada II.

Após análise detalhada das fichas percebeu-se que o material que aparecia aos $98 \mathrm{~cm}$ de profundidade correspondia a fragmentos soltos, provavelmente perturbados, e que na verdade os ossos começam a aparecer desde o nível 30-40 cm, e foram aumentando em quantidade. Esse material foi associado em campo ao sepultamento I, entretanto sua origem pode ser de outro sepultamento, visto que ela não está estruturada.

\section{2- Descrição do sepultamento}

Este sepultamento foi escavado em campo com ajuda de fotos polaróides, onde foi anotado o PN de alguns ossos retirados. Infelizmente há uma grande 


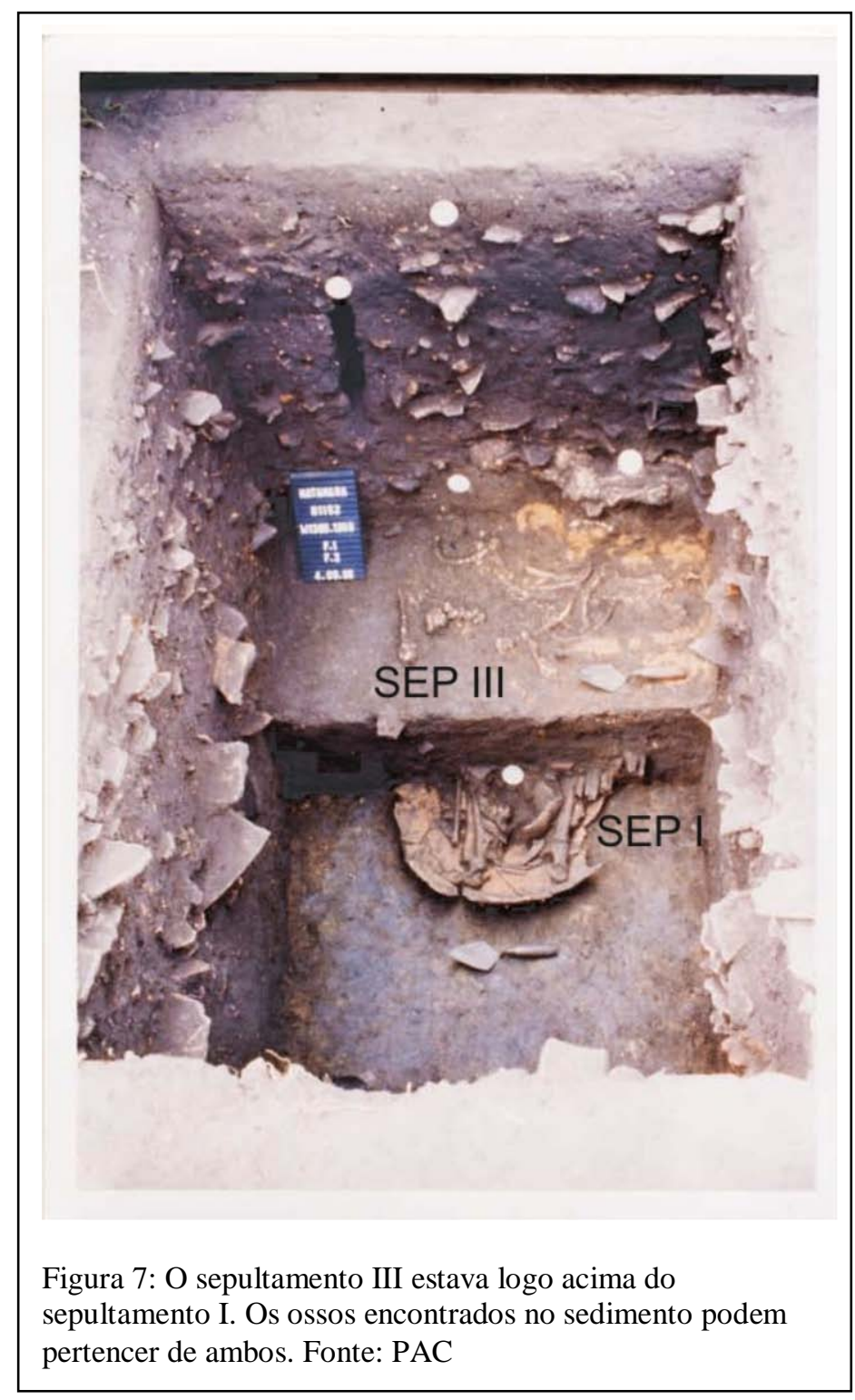

pertencer de ambos. Fonte: PAC

dificuldade de se relacionar os números anotados nas fichas com os anotados nos ossos.

O sepultamento I é múltiplo, visto os ossos identificados em laboratório e em urna. Pelas fotos e descrições os ossos longos estavam paralelos uns aos outros e concentrados ao norte e sul da urna (ver figura 6). Há certa confusão nos ossos identificados em campo, mas aparentemente o crânio se encontrava no fundo da urna na parte central. Os ossos parecem organizados e não foi possível identificar em campo ou através das fotografias conexões, indicando ser um sepultamento secundário. Entretanto, é interessante notar a presença de falanges de mão e ossos muito pequenos do indivíduo mais jovem (arco vertebral de atlas). Este pode ter sido colocado inteiro, mas com a decomposição das partes moles e um espaço vazio considerável seus ossos teriam se espalhado.

Esse sepultamento apresenta um contexto particular comparado a todos os outros sepultamentos encontrados nos montículos. Inicialmente classificado como pertencente à fase Guarita (Machado, 2005), por causa das características morfológicas e decorativas da urna, foi, entretanto, após reanálise, considerado como provavelmente da fase Açutuba, a mais antiga da região.

Outras particularidades desse sepultamento são as datas obtidas sobre o material, que são antigas (HAT 1739: 485 d.C., BETA 145483; HAT 1798: 640 d.C., 


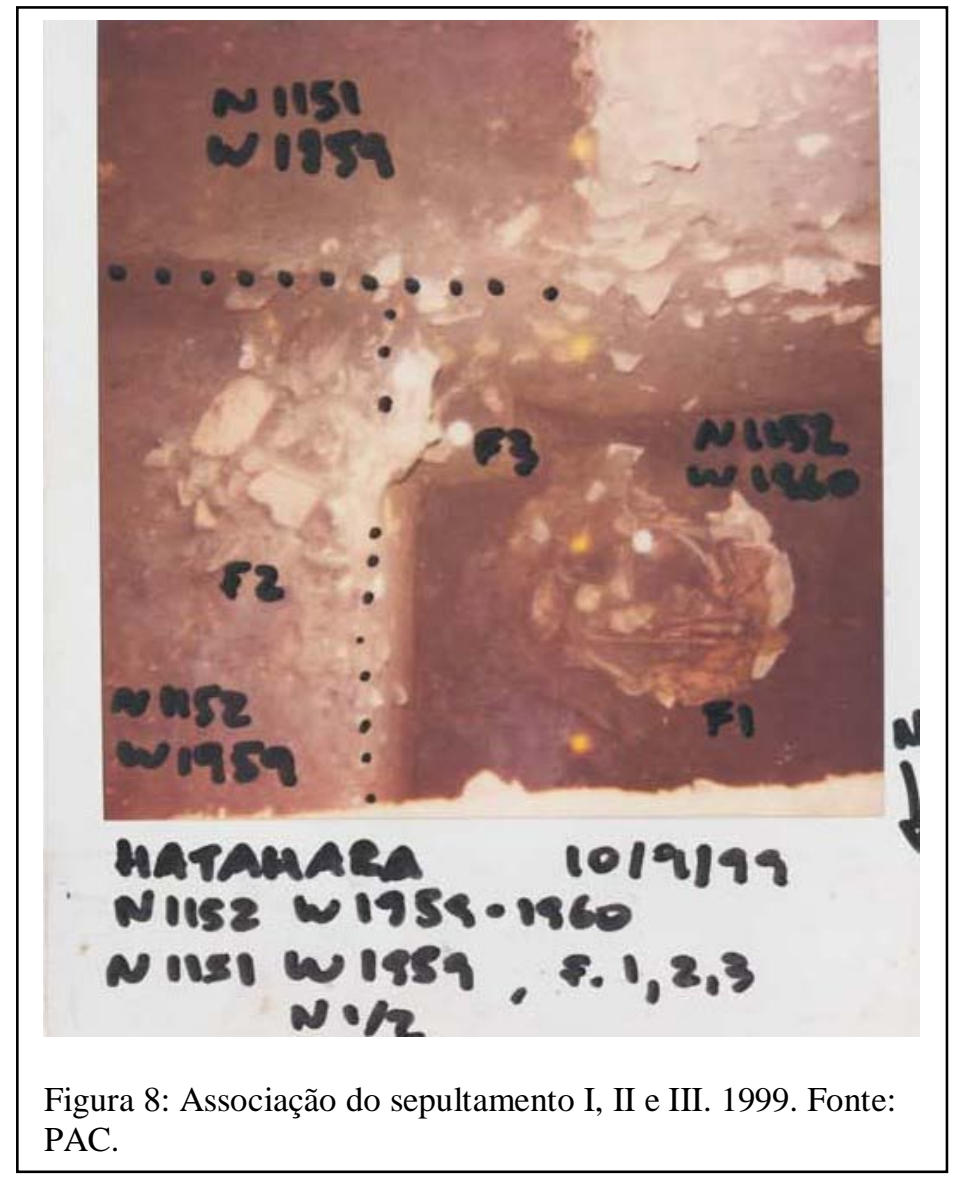

BETA 145484); e o fato de ser o único em urna e em montículo ao mesmo tempo; por fim, como mencionado anteriormente, a urna estava mais profunda que os outros enterramentos.

A urna foi perturbada após a deposição, as causas dessa perturbação não são claras. Mas é possível e, mesmo provável, que estejam ligadas a enterramentos posteriores (sepultamento II e III, ver figura 7 e 8), que, mesmo estando ao lado e não diretamente em cima, podem ter impactado a urna durante a abertura da área, mas não há sinais de fossa.

No geral os ossos estão em estado de conservação média, quase todos fragmentados, as epífises dos ossos longos grandes desapareceram quase todas. Entretanto, vale ressaltar que esse sepultamento está com uma qualidade de conservação melhor que o material de 2006. Pensamos que isso tem haver com a própria escavação. A abertura de unidades no montículo teve um grande impacto no material que permaneceu, veremos mais detalhes sobre esse processo no decorrer desse capítulo.

Nesse sepultamento foram encontrados vestígios ósseos de quatro indivíduos dentro de um recipiente cerâmico, dois adultos, um sub-adulto e um infantil. Entretanto, Rafael Bartolomucci, que fez uma curadoria inicial, indicou ter encontrado um quinto indivíduo a partir de dentes. Quando a análise foi refeita o quinto indivíduo não foi identificado.

Uma grande quantidade de material ficou indeterminada, principalmente para os adultos, para os quais nem sempre era possível distinguir pela morfologia. Junto 
com o material dos jovens foram encontrados ossos de mamíferos pequenos. Existem dois ossos coxais que deveriam ser atribuídos ao indivíduo C, pela idade óssea. Entretanto, como os ossos não pareiam, este pode ser um efeito de percolação, osso oriundo de um sepultamento mais acima, II ou III. Outra possibilidade é que o indivíduo C não era simétrico para alguns ossos.

Abaixo está um resumo das análises sobre o material ósseo em laboratório.

\begin{tabular}{|l|l|l|l|}
\hline Indivíduo & Idade & Sexo & Observações \\
\hline A & Adulto & $\begin{array}{l}\text { Não } \\
\text { identificado }\end{array}$ & $\begin{array}{l}\text { Inserções musculares } \\
\text { muito marcadas }\end{array}$ \\
\hline B & Adulto & $\begin{array}{l}\text { Não } \\
\text { identificado }\end{array}$ & - \\
\hline C & Sub-adulto & $\begin{array}{l}\text { Não } \\
\text { identificado }\end{array}$ & $\begin{array}{l}\text { Poucos } \\
\text { preservados }\end{array}$ \\
\hline D & Infantil & $\begin{array}{l}\text { Não } \\
\text { identificado }\end{array}$ & $\begin{array}{l}\text { Ossos muitos finos e } \\
\text { fragmentados }\end{array}$ \\
\hline
\end{tabular}

\section{SEPULTAMENTO II}

$\begin{array}{ccc} & \text { As } & \text { informações } \\ \text { campo } & \text { para } & \text { esse }\end{array}$
sepultamento provem das fichas e cadernos de campo de 1999, enquanto que as informações de laboratório foram adquiridas em 2007/2008.

\section{1- Localização}

Esse sepultamento (ver figuras 8 e $\quad 9$ ) foi descoberto durante a abertura da unidade N1152W1359 $1 / 2 \mathrm{~N}$ para a retirada do sepultamento I, inicialmente chamado de feição 2. De

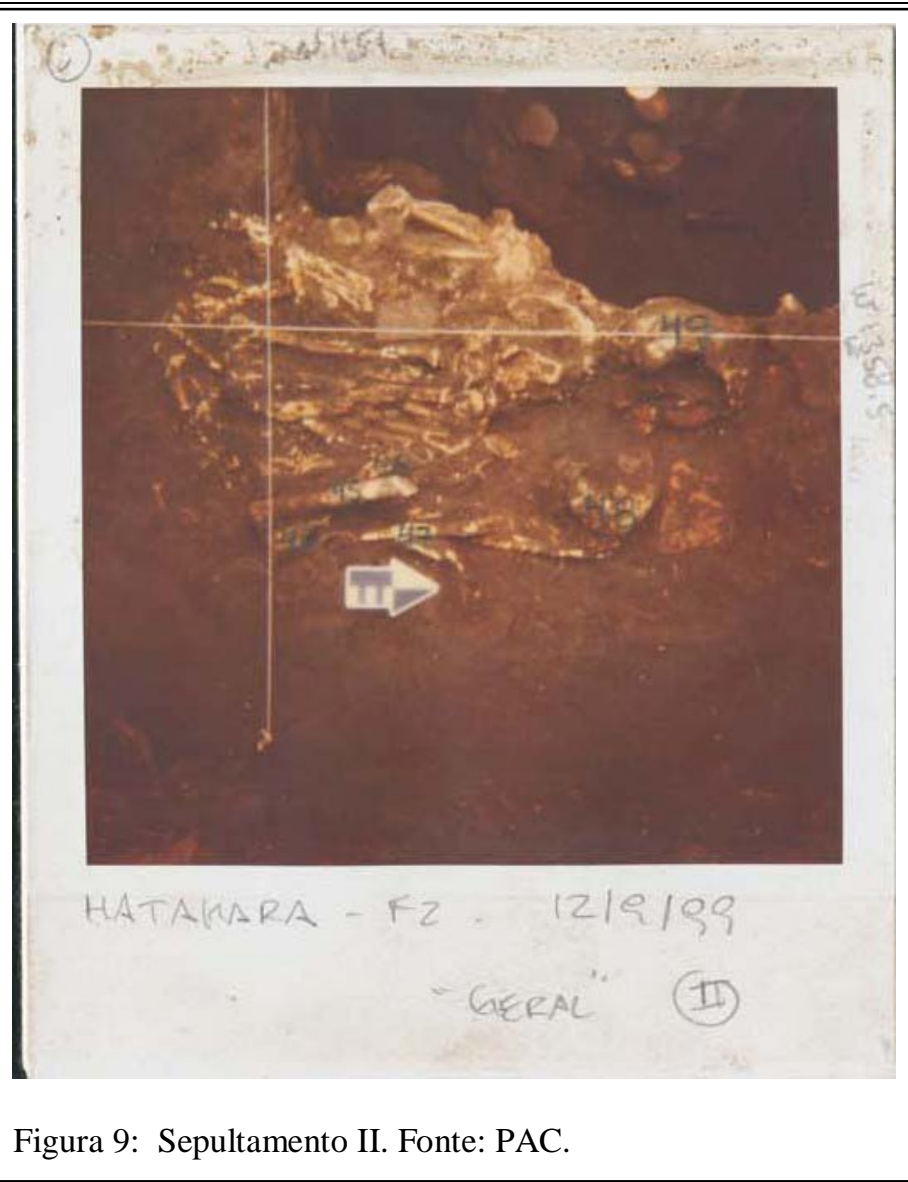
acordo com as fichas de campo este apareceu aos $76 \mathrm{~cm}$ e continuou até os $88 \mathrm{~cm}$ de 
profundidade, entretanto ele apresenta o mesmo problema que o sepultamento anterior quanto ao DATUM. Em campo, este sepultamento foi identificado como estando entre as camadas B e A. De acordo com Machado (2005) isso deve corresponder à camada IV, etapa de construção do montículo.

Está associado a manchas de sedimento escuro mosqueado de sedimento

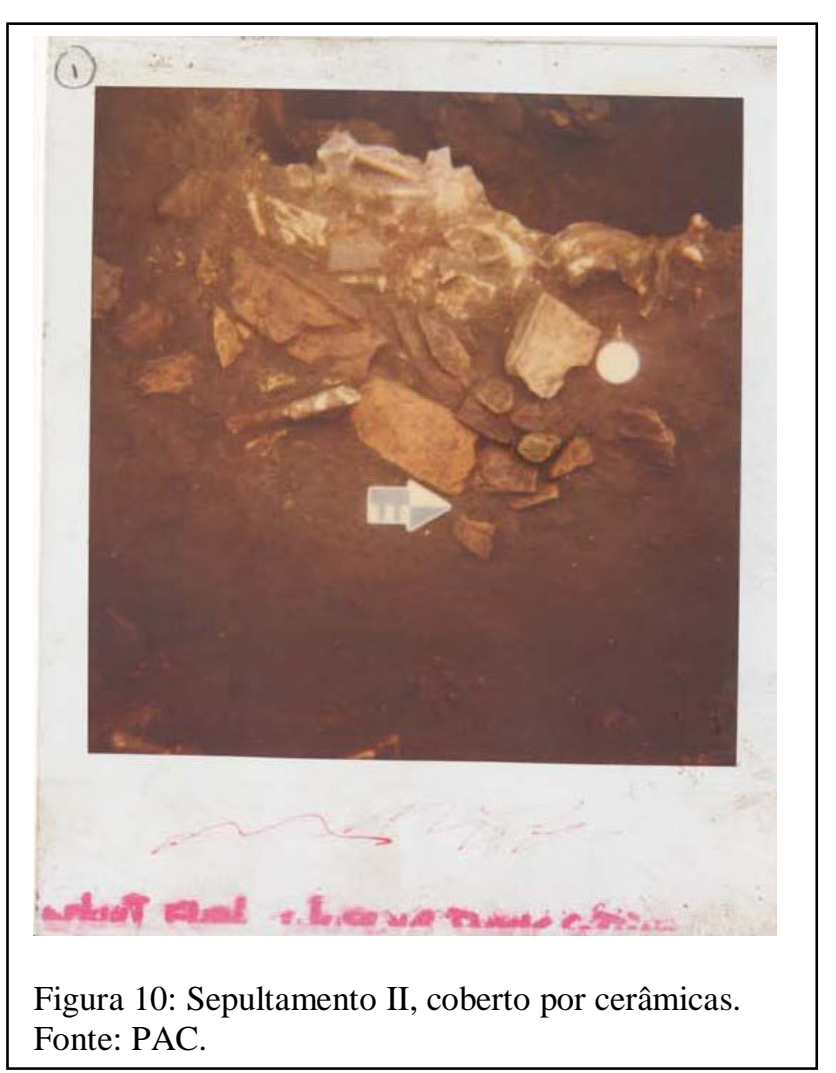
amarelado, o que aparentemente cobriam e isolavam o sepultamento.

\section{2- Descrição do sepultamento}

Pela descrição e, principalmente pelas fotos, o sepultamento parece ser secundário, sendo muito difícil saber o grau de perturbação do sepultamento (ver figura 9). Não é claro se há ou não relação direta entre esse sepultamento e o sepultamento III. Em campo eles aparecem próximos e devem ter perturbado o sepultamento I durante a abertura de suas covas.

Como para o sepultamento I foram utilizadas polaróides como foto-croquis, os ossos longos estão paralelos (em feixe) e não há como ter certeza sobre a posição dos ossos pequenos. Uma grande quantidade de cerâmica estava sobre o sepultamento (ver figura 10 e 11), muitos fragmentos de tamanho significativo. Visto a proximidade das cerâmicas e dos ossos, esses devem estar associados, esta relação parece diferente da geralmente percebida de feições com muita cerâmica e fauna perto de sepultamentos, pois nesse caso a cerâmica cobre o sepultamento. Apesar de não se poder afirmar que os fragmentos delimitavam a cova, este fato leva a considerar mais um tipo de gesto funerário. 
Esse sepultamento foi datado diretamente por $14 \mathrm{C}$ (HAT 1578 obteve uma data de 935 d.C., BETA 145486) a data obtida e o contexto (fragmentos cerâmicos e posição estratigráfica) desse material o associam à fase Paredão.

Seguindo o protocolo determinado para laboratório

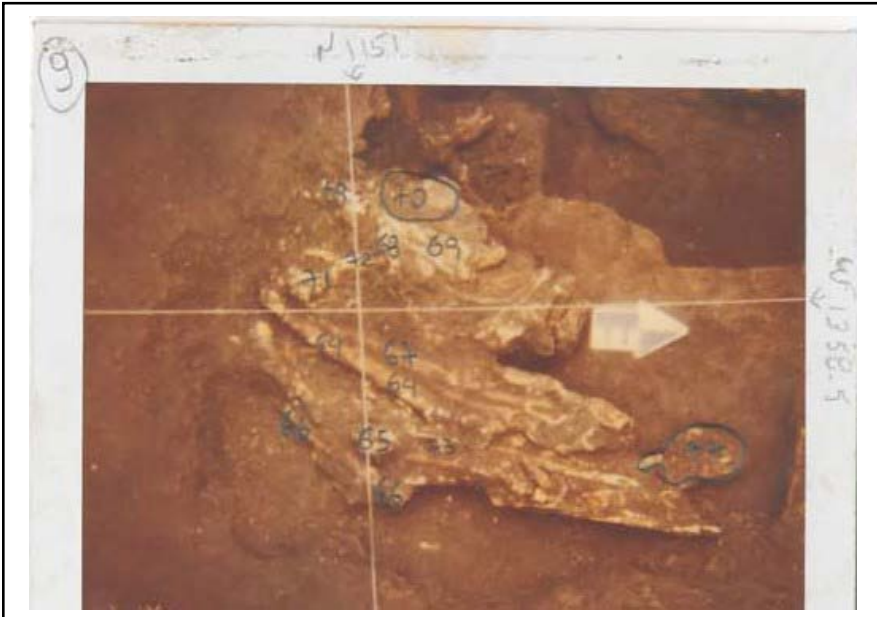

Figura 11: Segunda fase de desmontagem do sepultamento II.Fonte: PAC.

pode-se identificar cinco indivíduos, dois adultos e dois infantis e um sub-adulto, em nenhum deles foi possível determinar o sexo e a idade para os adultos é muito imprecisa.

Abaixo está resumido os dados das análises sobre o material ósseo em laboratório.

\begin{tabular}{|c|c|c|c|}
\hline Indivíduo & Idade & Sexo & Observações \\
\hline A & $\begin{array}{l}\text { Adulto } \\
\text { Velho }\end{array}$ & $\begin{array}{l}\text { Não } \\
\text { identificado }\end{array}$ & $\begin{array}{l}\text { Inserções musculares } \\
\text { muito marcadas }\end{array}$ \\
\hline B & Adulto & $\begin{array}{l}\text { Não } \\
\text { identificado }\end{array}$ & $\begin{array}{l}\text { Inserções musculares } \\
\text { muito marcadas }\end{array}$ \\
\hline $\mathrm{C}$ & $\begin{array}{l}\text { Infantil } \\
\text { (aprox. } 2 \\
\text { anos) }\end{array}$ & $\begin{array}{l}\text { Não } \\
\text { identificado }\end{array}$ & $\begin{array}{l}\text { Muitas porosidades, idade } \\
\text { definida pelo tamanho da } \\
\text { fíbula }\end{array}$ \\
\hline D & $\begin{array}{l}\text { Sub-adulto } \\
\text { (aprox. } 15 \\
\text { anos) }\end{array}$ & $\begin{array}{l}\text { Não } \\
\text { identificado }\end{array}$ & $\begin{array}{ll}\text { Idade definida } & \text { pelo } \\
\text { tamanho e pontos não } \\
\text { ossificados }\end{array}$ \\
\hline $\mathrm{E}$ & $\begin{array}{l}\text { Infantil } \\
\text { (aprox. } 5 \\
\text { anos) }\end{array}$ & $\begin{array}{l}\text { Não } \\
\text { identificado }\end{array}$ & \begin{tabular}{|lll}
$\begin{array}{l}\text { Idade } \\
\text { dentes }\end{array}$ & definida & pelos \\
\end{tabular} \\
\hline
\end{tabular}

\section{SEPULTAMENTO III}

As informações de campo para esse sepultamento provêm das fichas e cadernos de campo de 1999, enquanto que as informações de laboratório foram adquiridas posteriormente em 2007. 


\section{1- Localização}

Este sepultamento (ver figura 12) foi encontrado próximo ao sepultamento II

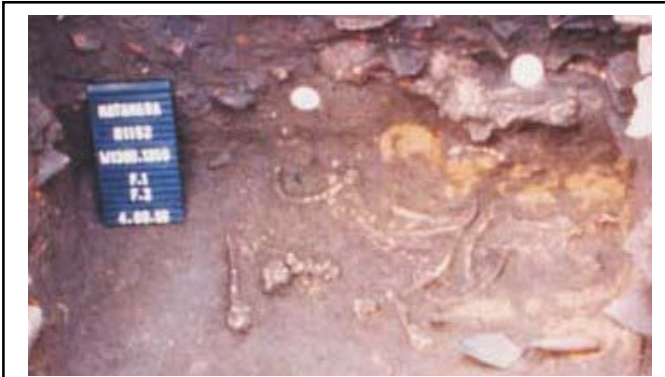

Figura 12: Foto do Sepultamento III. Fonte: PAC. (ver figura 7 e 8) durante a abertura da unidade para retirada desse último. O indivíduo estava enterrado nas unidades N1152W1359 e N1152W1360, entre 96cm e $107 \mathrm{~cm}$ de profundidade. Na ficha de campo da unidade N1152W1359 1/2W, nível 100-110 cm está escrito: “chamamos

a concentração de ossos entre F1 e F2 de F3, pela grande presença de ossos e outro crânio o que pode indicar outro sepultamento”. Este sepultamento estava coberto de manchas de argila laranja/amarela (latossolo), diferente do sepultamento XIX (que veremos mais adiante). A argila amarela aqui aparece misturada ao sepultamento e não como uma cobertura.

\section{2- Descrição do sepultamento}

Este sepultamento tem uma disposição particular. As costelas estavam esparramadas nas fotos e nos desenhos, mas relativamente próximas. Não é possível perceber uma organização parecida com os sepultamentos secundários. Ao contrário, os ossos estão separados como se tivessem tido muito espaço para se movimentar (ao longo da decomposição?). O que pode ter acontecido é um espaço vazio ter permanecido presente durante um tempo longo o suficiente para que as costelas “abrissem”. É interessante notar que esse efeito geralmente é mais observado em crianças (Duday, 2005). Isso pode ser um indício de que a coluna e as costelas não estavam em contato direto com a terra (ou superfície plana) e, sim, sobre algum elemento que causasse essa abertura. Se realmente existiu um espaço grande para que a decomposição acontecesse, isso é indício de um gesto funerário particular, pois em geral o que acontece é o oposto, o espaço é bastante reduzido.

Acreditou-se no começo que os sepultamentos I, II e III estivessem relacionados. Entretanto, ao que parece, não há vínculos entre o sepultamento I e os outros dois, tanto pelas datas obtidas quanto pelo modo de inumação. Um dos ossos do indivíduo pertencendo ao sepultamento III foi datado diretamente por 14C e a data obtida corresponde à fase Paredão (HAT 1175.5, data 980 d.C., BETA 242439). 
A argila que está junto a esse sepultamento parece ter sido colocada intencionalmente, pois ela está concentrada sobre os ossos e sua presença cria um aspecto visual importante. Em outros momentos também encontramos pequenas manchas de latossolo junto com a terra preta em camadas superiores aos sepultamentos, nesse caso acredita-se que a presença dessas pequenas quantidades de argila seja em função da escavação das covas e não como um ato intencional.

Alguns ossos de indivíduos muito jovens apareceram junto aos ossos

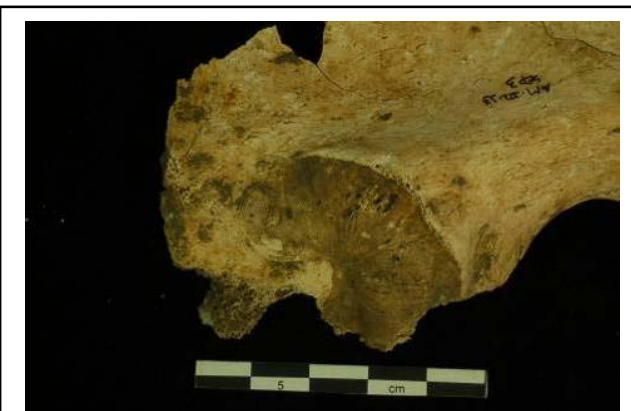

Figura 13: Detalhe do osso coxal do sepultamento III, superfície auricular de aspecto jovem. analisados, mas eles parecem ser intrusivos. Nas fichas há menção de outro crânio, mas ele não foi encontrado.

Nesse sepultamento encontrou-se as ossadas de um único indivíduo, que aparenta ser um sub-adulto/adulto jovem. A extremidade esternal da clavícula não estava ossificada, além disso, a superfície auricular (Buikstra e Ubelaker, 1994) indica aproximadamente 19 anos de idade (ver figura 13). Comparado aos esqueletos dos outros sepultamentos, os ossos são relativamente pequenos. Pelo método de Bruzek (1991), a estimativa de sexo pelo osso coxal esquerdo é de que seja feminino.

\begin{tabular}{|l|l|l|l|}
\hline Indivíduo & Idade & Sexo & Observações \\
\hline A & $\begin{array}{l}\text { Adulto } \\
\text { jovem }\end{array}$ & feminino & - \\
\hline
\end{tabular}

\section{SEPULTAMENTO IV}

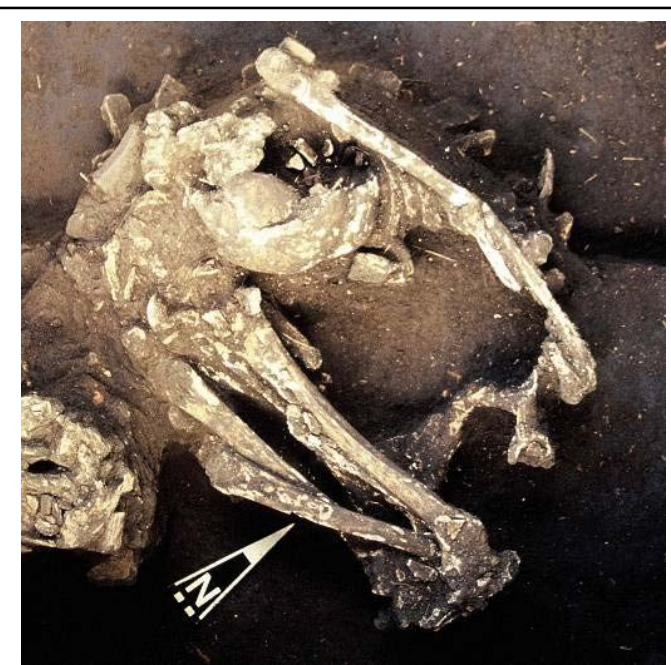

As informações de campo para esse sepultamento provem das fichas e cadernos de campo de 2001, enquanto que as análises laboratoriais foram feitas em 2007/2008.

\section{1- Localização}

Sepultamento (ver figura 14)

Figura 14: Sepultamento IV. Foto: R. Bartolomucci. 
localizado ao norte das escavações do montículo I, entre N1160W1360 e N1160W1359, a 90cm de profundidade (base). Este sepultamento foi encontrado em laboratório, mais ou menos lavado, e numerado (com número do sítio e $\mathrm{PN}$ ), com alguns ossos colados. Ele parece ter sido todo desmontado em campo com PNs individuais por osso, mas sem muita descrição nas fichas de campo.

\section{2- Descrição do sepultamento}

A conservação dos ossos está relativamente boa. Pelos croquis, o indivíduo foi colocado em decúbito lateral (com possivelmente uma declividade

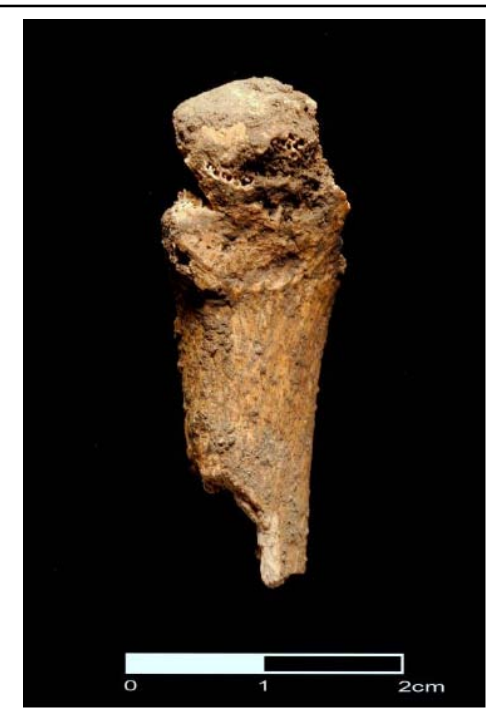

Figura 15: Articulação supranumerária. Sepultamento IV. Foto: Wagner Souza e Silva. do crânio em direção a pélvis) com as pernas fletidas ao lado direito deste. Este sepultamento é primário - de acordo com as fotos (ver figura 14), o croqui (seqüência anatômica do braço esquerdo, das costelas e vértebras, e da pelve e fêmur), a presença de ossos pequenos e alguns pequenos blocos de ossos curtos em conexão também indicam que a decomposição se fez in situ. O crânio caiu em um espaço vazio deixado pela decomposição da caixa torácica.

Pelas fotos tem-se a impressão de uma compressão forte sobre o corpo, as costelas parecem ter permanecido em pé, na área da cintura escapular e, ao lado direito do indivíduo, vê-se um efeito de parede muito nítido. A perna parece hiperfletida. Todo o sepultamento parece contido dentro de um espaço reduzido. A cova era provavelmente pequena em diâmetro o que explicaria o declive do corpo e a queda do crânio. Também percebe-se ossos em posições instáveis (ossos articulados uns sobre os outros), sugerindo um preenchimento rápido da cova. Isso pode indicar um possível sepultamento direto.

Um detalhe interessante sobre a anatomia do indivíduo é que ele apresenta uma articulação de agachamento no primeiro metatarso direito (squating facetshyperdorsiflexion of metatarsophalangeal joints Ubelaker, 1979) (ver figura 15). Esse indivíduo era um adulto, todas as extremidades visíveis estavam ossificadas. 


\begin{tabular}{|l|l|l|l|}
\hline Indivíduo & Idade & Sexo & Observações \\
\hline A & Adulto & $\begin{array}{l}\text { Não } \\
\text { identificado }\end{array}$ & $\begin{array}{l}\text { Articulação de } \\
\text { agachamento no MTTI }\end{array}$ \\
\hline
\end{tabular}

\section{SEPULTAMENTO V}

Esse sepultamento foi escavado em 2001, mas a análise só foi efetuada em 2007/2008.

\section{1- Localização}

Este sepultamento (ver figura 16) foi encontrado na quadra N1160W1359 e retirado em dois blocos aos $77 \mathrm{~cm}$ de profundidade.

\section{2- Descrição do sepultamento}

Dois blocos foram retirados para esse sepultamento. Ambos correspondem

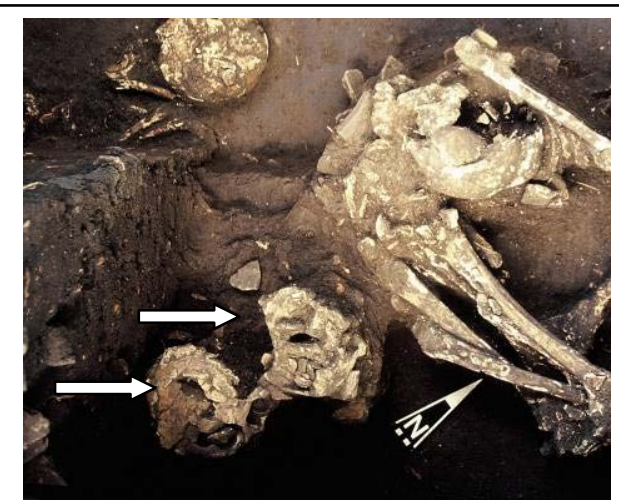

Figura 16: Sepultamento V (setas brancas). Foto: R. Bartolomucci. principalmente a crânios, os quais, apesar de fragmentados, pode-se afirmar que pertenciam a dois indivíduos distintos. Visto que esses crânios parecem isolados, é possível que eles façam parte de um gesto funerário particular, provavelmente parecido com o que aconteceu com os sepultamentos XV e XVIII, onde crânios aparecem isolados com poucos ou sem vestígios dos ossos do pós-crânio.

Os crânios aqui encontrados estão muito fragmentados e a conservação é ruim. O primeiro (PN 3591), apesar de pequeno parece ser adulto ou sub-adulto, enquanto que o segundo (PN 3592) é provavelmente infantil e tem alguns ossos do pós-crânio associados.

\begin{tabular}{|l|l|l|l|}
\hline Indivíduo & Idade & Sexo & Observações \\
\hline A & $\begin{array}{l}\text { Adulto ou } \\
\text { sub-adulto }\end{array}$ & $\begin{array}{l}\text { Não } \\
\text { identificado }\end{array}$ & Pequeno \\
\hline B & Infantil? & $\begin{array}{l}\text { Não } \\
\text { identificado }\end{array}$ & - \\
\hline
\end{tabular}

\section{SEPULTAMENTO VI}

\section{1-Localização}

Este sepultamento foi encontrado entre as quadras N1160W1359 e 


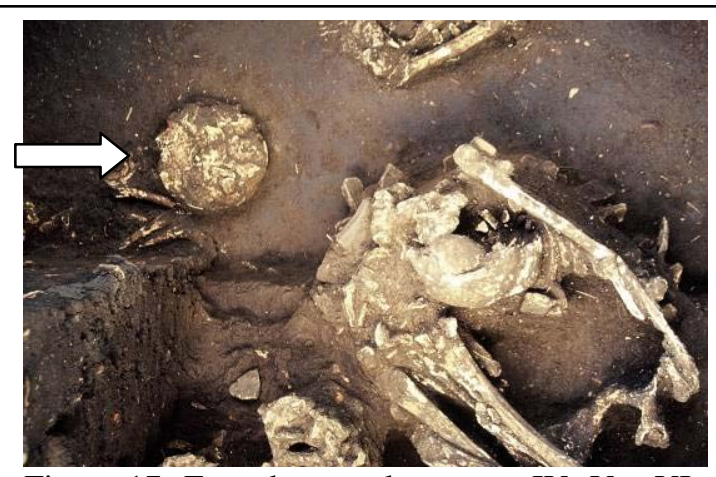

Figura 17: Foto dos sepultamentos IV, V e VI. A seta branca indica o número VI. Foto: R. Bartolomucci.

N1160W1360 aos 105 cm de profundidade. Esse material foi coletado em 2001 (ver figura 17), mas a análise laboratorial só foi realizada em 2008.

\section{2- Descrição do sepultamento}

Este sepultamento foi pouco descrito nas fichas de campo e pelas fotos não é possível determinar o tipo de

enterramento, mas ele é individual. A análise em laboratório mostrou que esses restos pertenciam a um indivíduo infantil (ver figuras 18 e 19), aproximadamente 6 anos (de acordo com Buikstra
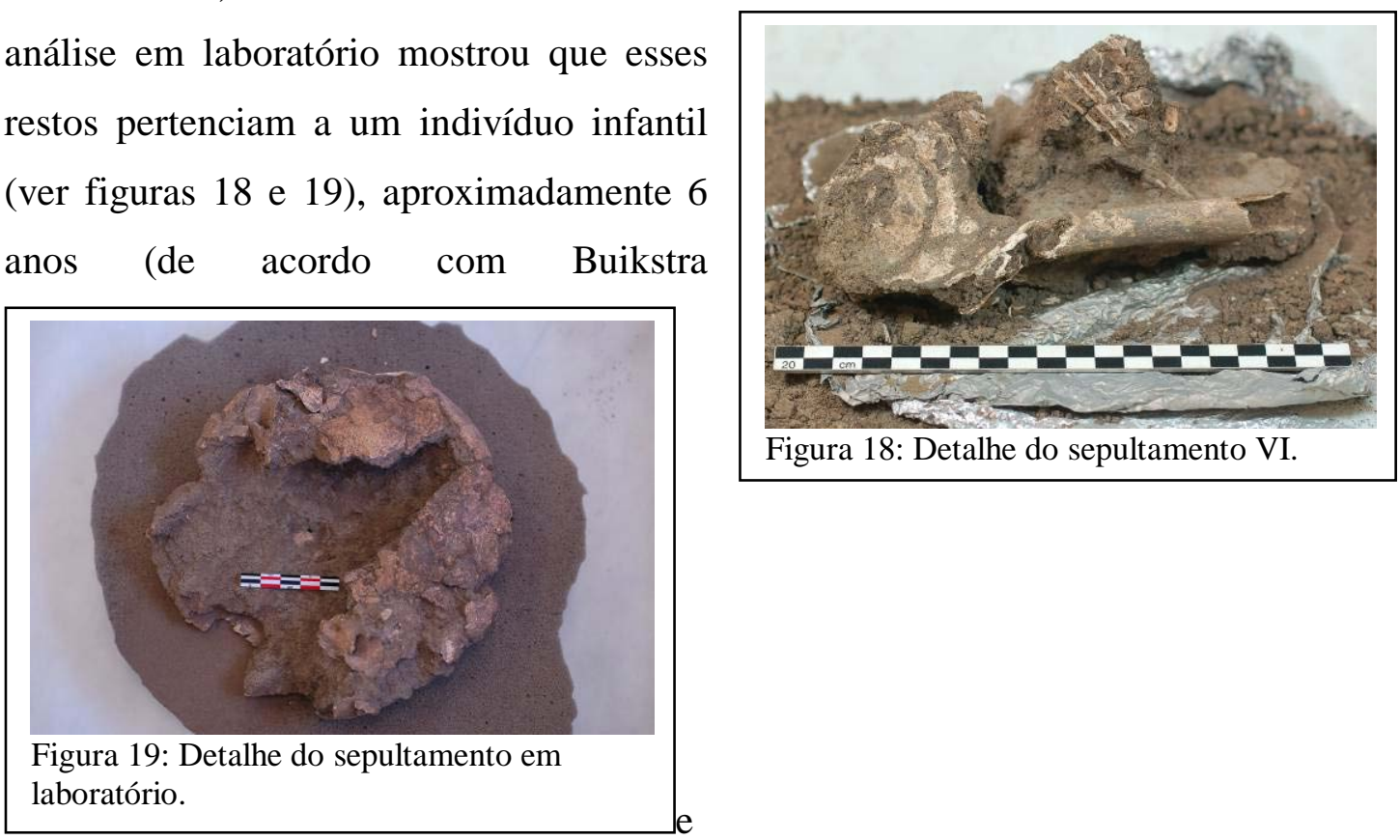

Ubelaker, 1994).

Os vestígios são todos frágeis, mas foi possível identificar uma vértebra de animal, provavelmente um réptil ou anfíbio, dentro do crânio.

\begin{tabular}{|l|l|l|l|}
\hline Indivíduo & Idade & Sexo & Observações \\
\hline A & Infantil & $\begin{array}{l}\text { Não } \\
\text { identificado }\end{array}$ & Possível fauna associada \\
\hline
\end{tabular}

\section{SEPULTAMENTO VII}

\section{1- Localização}

Sepultamento encontrado na quadra N1159W1360, aos $77 \mathrm{~cm}$ de profundidade. Os ossos relacionados a esse sepultamento estavam sobre uma 


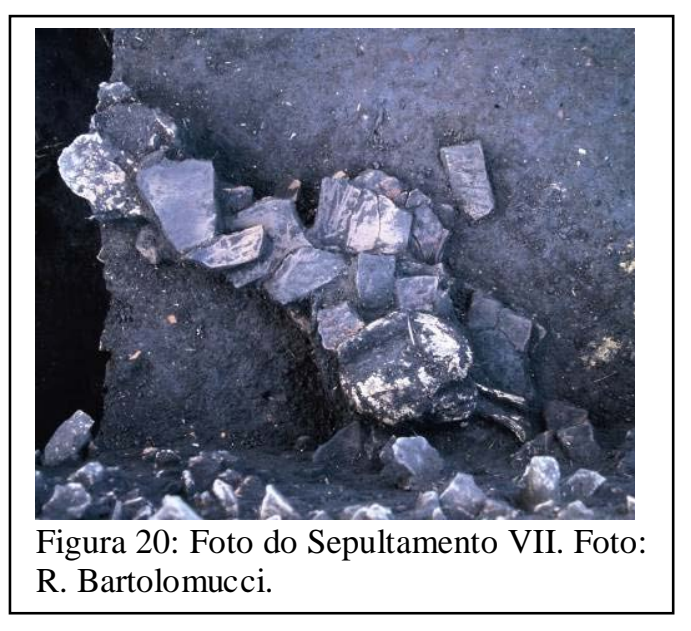

concentração de cerâmicas horizontais (ver figura 20). Não está claro se existe alguma associação. É possível que seja apenas a camada de construção do montículo. Não foi identificado em campo negativos de cova.

\section{2- Descrição do sepultamento}

Este sepultamento parece ter sido bastante perturbado, não sendo possível afirmar se ele é primário ou secundário. Seguindo as informações de Machado (2005) e Neves et al. (2003), esse sepultamento seria material perturbado, oriundo de outro lugar e, que teria sido utilizado como material de construção. Entretanto, devido à conexão crânio-mandíbula (ver figura 21), identificada em laboratório, ele é provavelmente primário. Pois, a conexão entre ossos em sepultamentos secundários é rara, ela pode ocorrer se as partes do indivíduo foram colocadas ainda em processo de decomposição (Duday, comunicação pessoal). No caso da articulação temporomandibular, não é possível descartar a possibilidade de que ela possa ser encontrada com os ossos secos. Entretanto, os dados de campo são insuficientes para chegar a uma conclusão.

As dúvidas existentes sobre o fato de ser ou não um sepultamento atestam o quão complexo é o contexto em questão. Machado (2005) afirma que outros ossos longos foram identificados mais abaixo da cerâmica e que poderiam pertencer a esse indivíduo. Mas estes não foram

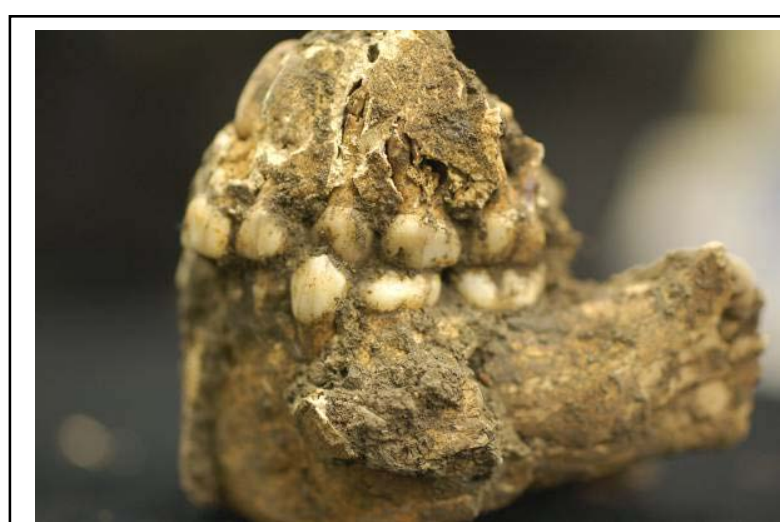

Figura 21: Sepultamento VII. Detalhe mandíbula e maxila. encontrados e não seria lógico os ossos do pós-crânio estarem separados do crânio por camadas de cerâmica e terra.

\begin{tabular}{|l|l|l|l|}
\hline Indivíduo & Idade & Sexo & Observações \\
\hline A & Infantil & $\begin{array}{l}\text { Não } \\
\text { identificado }\end{array}$ & $\begin{array}{l}\text { Dúvidas sobre a relação } \\
\text { mandíbula-crânio }\end{array}$ \\
\hline
\end{tabular}




\section{SEPULTAMENTO VIII}

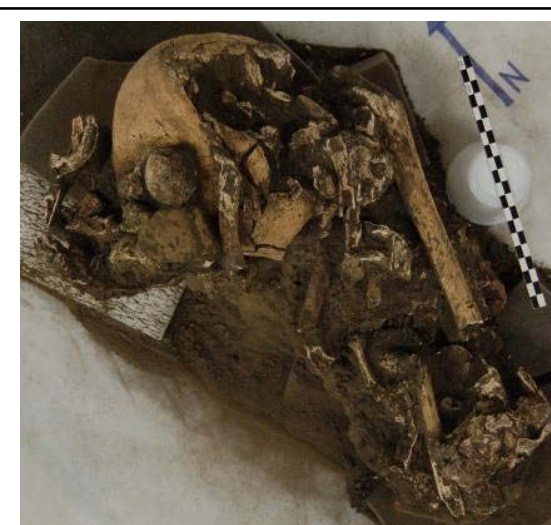

Figura 22: Foto do sepultamento VIII. Foto: Claide Moraes.

Sepultamento primário retirado em bloco em 2001 e escavado em laboratório em 2007. Alguns ossos foram retirados e lavados antes da escavação, mas foram facilmente identificados com ajuda dos croquis.

\section{1- Localização}

Esse sepultamento (ver figura 22) estava na unidade N1160W1360, situado a $110 \mathrm{~cm}$ de profundidade (base). Na concentração de sepultamentos (chamado de bolsão 2 por Machado, 2005 e Neves et al., 2003) encontrada em 2001. Em campo estava associado um aplique em forma de cabeça redonda, típico da fase Paredão

\section{2- Descrição do sepultamento}

Inicialmente

sepultamento foi considerado como secundário (ver figura 23). Entretanto, após a primeira limpeza em laboratório, compreendeu-se que era um

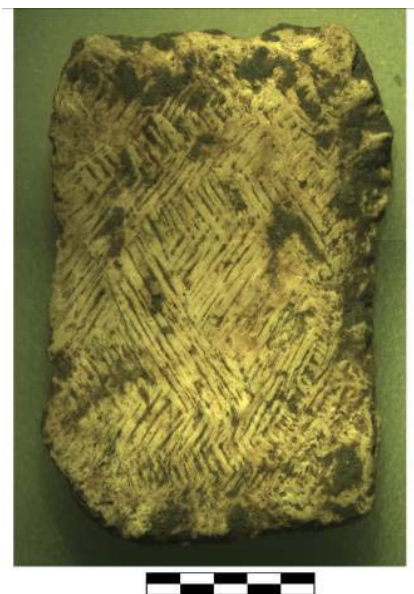

Figura 24: Fragmento de fauna com marca de cestaria encontrada no sepultamento XIII. Foto: Myrtle Shock. esse

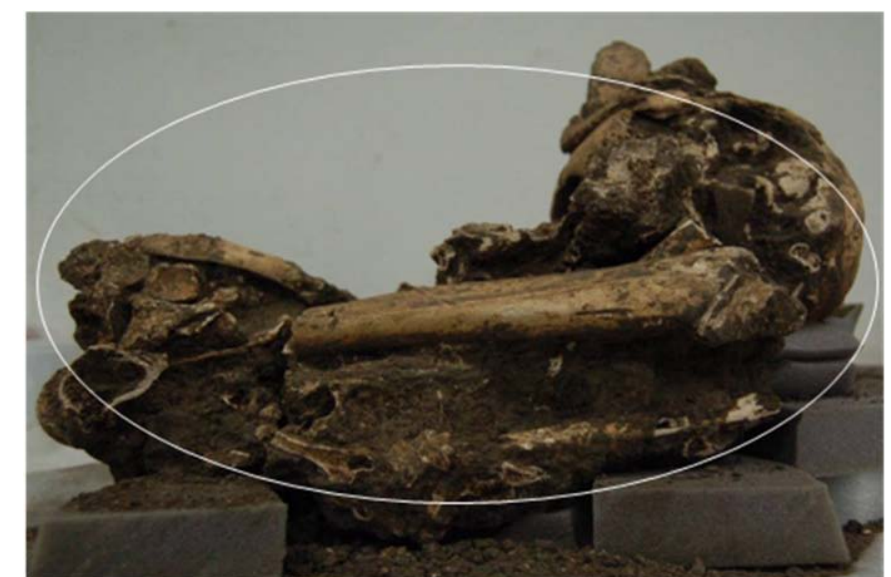

Figura 23: Sepultamento VIII. Delimitação do espaço está presente. Grande movimentação dos ossos. Foto: Claide Moraes.

indivíduo em decúbito dorsal com pelo menos a perna esquerda fletida sobre o corpo. Os processos tafonômicos sofridos por esse sepultamento foram intensos, deixando o indivíduo extremamente remexido. Por exemplo, a perna direita não estava junto, muitas conexões anatômicas não estavam presentes e os ossos estavam por vezes muito afastados do seu local de origem.

Esses processos parecem ser todos de origem 
natural, quer dizer sem intervenção direta do homem. Após a decomposição das partes moles, formou-se um grande espaço vazio dentro da cova, o fato da terra ser extremamente argilosa parece ter criado uma cápsula externa e um vazio considerável mantido internamente. $\mathrm{O}$ efeito de parede ao redor do crânio e dos membros esquerdos é um indício de onde estariam as "paredes da cova” ou pelo menos alguma coisa os limitava naqueles lugares.

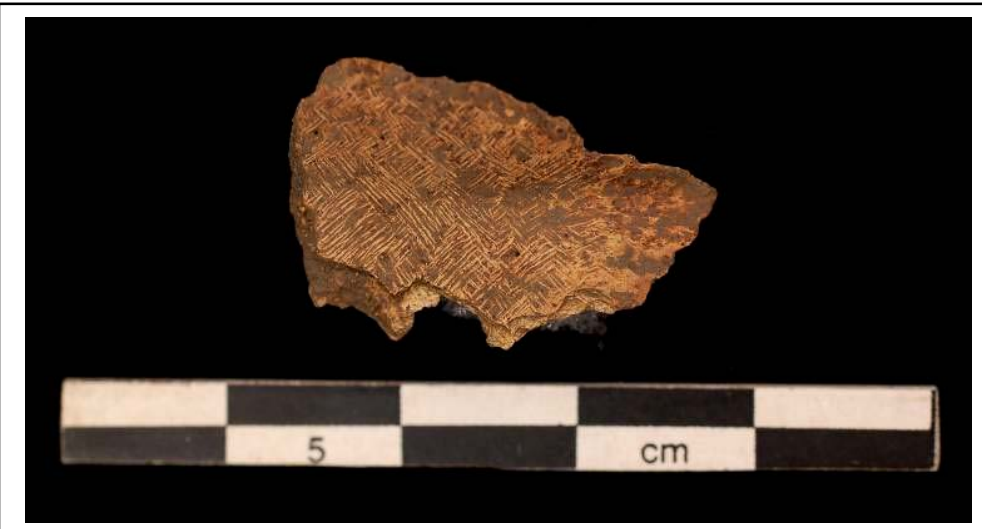

Figura 25: Fragmento de fauna com marca de cestaria encontrada no sepultamento XII.

O indivíduo deve ter sido enterrado em estado de decomposição avançado, permitindo assim que ele fosse comprimido (ex. hiperflexões das pernas). Tanto Wesolowski quanto Bartolomucci pensaram na possibilidade de haver um elemento tipo rede ou cesta contendo o sepultamento. Dois fragmentos de fauna retirados com os sepultamentos XII e XIII (ver figuras 24 e 25) podem vir a corroborar essa hipótese, pois neles estão presentes marcas muito regulares que devem provir de uma impressão por folhas ${ }^{13}$. Análises traceológicas não foram realizadas, mas visto o tamanho e a regularidade dificilmente essas marcas foram feitas manualmente.

Esse vazio facilitou o deslocamento de peças ósseas, assim como algumas ações naturais, como penetração de raízes. Como o bloco encontrado não mais representava o estado como o sepultamento fora descoberto em campo, não foi possível avaliar a ação dos animais (como tatu), pois esses vestígios geralmente são vistos pelo rastro de ossos e/ou aspecto do sedimento ao redor, ou falta dele.

\footnotetext{
${ }^{13}$ Como mencionado anteriormente alguns vegetais são ácidos e podem marcas os ossos com facilidade.
} 
Este indivíduo foi provavelmente enterrado ainda em conexão total ou quase. Parte da perturbação parece ter sido originada pelo crânio, que ao cair no espaço vazio criado pela decomposição, fez com que várias vértebras torácicas “pulassem” junto com outros ossos. O fato de o osso coxal direito ter ido se alojar ao lado

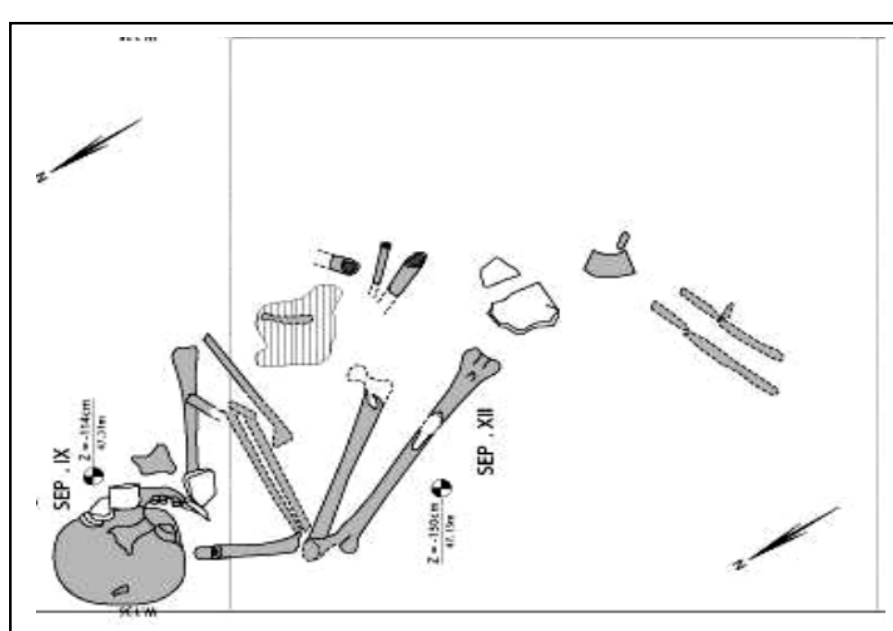

Figura 26: Junção dos croquis do sepultamento IX e XII, mostrando que são um só. Fonte: PAC. do crânio pode ser lido como um indício de um espaço extremamente restrito, onde o coxal estava mais alto que a coluna vertebral, pois o fundo da cova devia ser em forma de "bacia”. Ele também teria se deslocado com o crânio.

Os elementos ósseos desse sepultamento estão bem conservados. Dele pode-se retirar o coxal melhor preservado e mais completo da coleção. Quando analisado pelo método de Bruzek (1991), estimou-se que o indivíduo era do sexo feminino. Também foi aplicado a metodologia proposta por Buikstra e Ubelaker (1994), entretanto o resultado foi indeterminado. Para a idade, a superfície auricular foi analisada, como proposto por Buikstra e Ubelaker (1994), obteve-se uma idade de aproximadamente 35 anos, sendo, portanto, esse indivíduo classificado como um adulto.

$\mathrm{Na}$ tíbia esquerda desse indivíduo foi encontrada outra articulação de agachamento na face frontal da extremidade distal (squating facets, Ubelaker, 1979).

\begin{tabular}{|l|l|l|l|}
\hline Indivíduo & Idade & Sexo & Observações \\
\hline A & Adulto & Feminino & \\
\hline
\end{tabular}

\section{SEPULTAMENTO IX = SEPULTAMENTO XII}

\section{1- Localização}

Este sepultamento foi encontrado em 2001, mas só foi completamente analisado em 2008. Entretanto, desde o campo de 2002 ressaltou-se a probabilidade do sepultamento XII (retirado no ano de 2002) ser a continuação do sepultamento IX. O 
sepultamento (ver figura 26) foi encontrado entre as unidades N1158W1360 e N1159W1360 a base do sepultamento estando a $105 \mathrm{~cm}$ de profundidade.

\section{2- Descrição}

Esse sepultamento foi um desafio por várias razões. Primeiramente, visto que o sepultamento foi escavado em duas etapas de campo diferentes, a associação entre os ossos ficou mais difícil. Entretanto, vários conjuntos de ossos foram retirados em bloco, permitindo identificar relações típicas de sepultamentos primários (ver figura 26, 27 e 29). Nessas fotos eram visíveis continuações e justaposições correspondendo a anatomia humana (por exemplo, o crânio com a mandíbula e fíbula esquerda com a tíbia esquerda). Mesmo assim a perturbação parece muito intensa (ver figura 26 e 28).

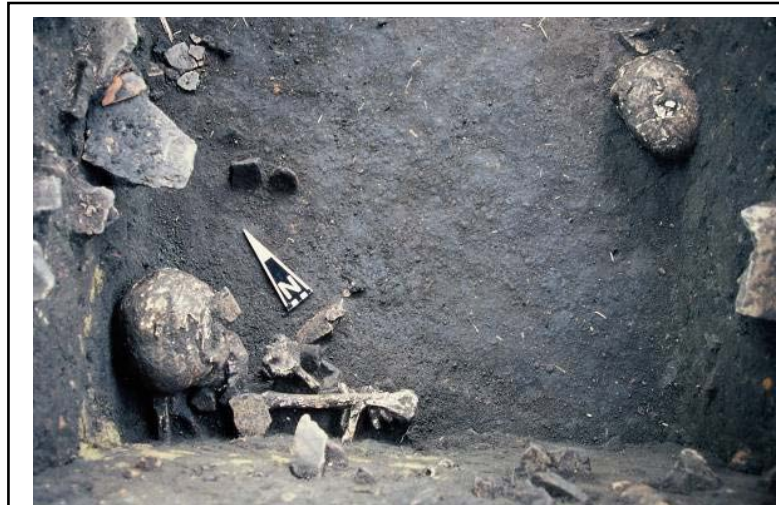

Figura 27: Sepultamento IX. Fonte: PAC.

Em seguida, pelas mesmas fotos, percebe-se uma conservação do material ósseo muito variável. O material que ficou próximo ao perfil (posteriormente chamado de sepultamento XII) criado pela escavação

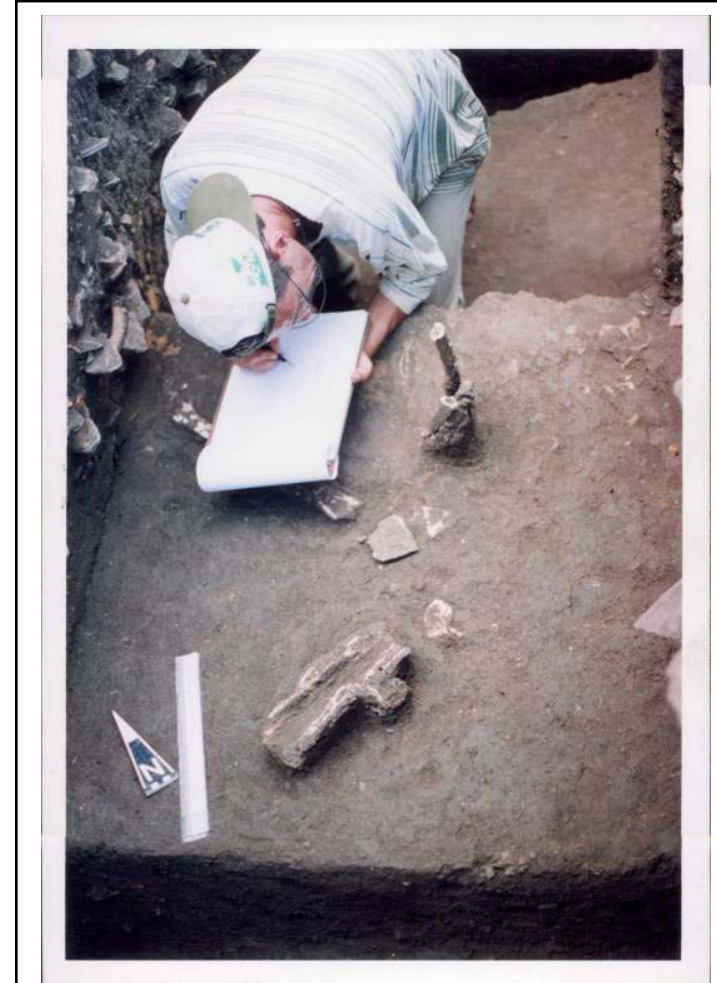

Figura 28: Croquis do sepultamento XII sendo feito. Muito perturbado. Fonte: PAC. de 2001, sofreu com o impacto da atmosfera (ver figura 30 e 31). As mudanças de temperatura e umidade o fragilizaram, ao ponto que alguns esfarelavam durante a limpeza em laboratório. 


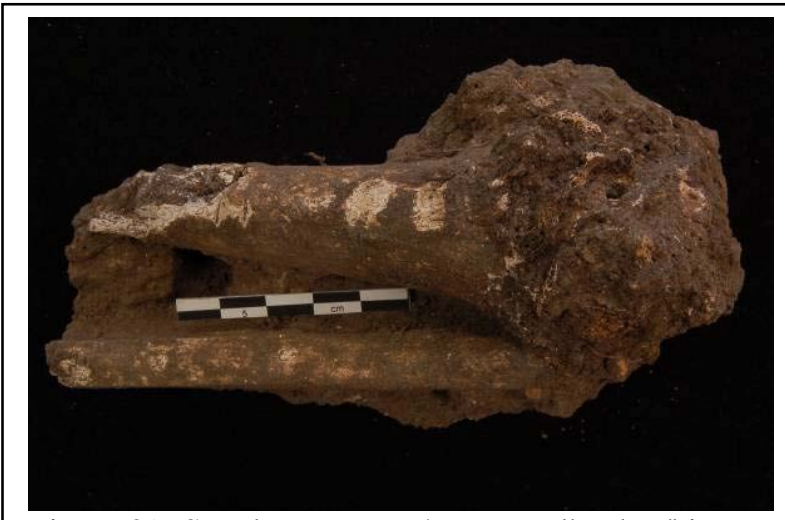

Figura 29: Sepultamento IX/XII. Detalhe da tíbia e fíbula esquerda.
Outro elemento interessante foi perceber certa quantidade de material ósseo de fauna associado. Dentre eles tem-se um fragmento com prováveis marcas de vegetais (ver figuras 24 e 25), mencionado anteriormente. Esse fragmento leva a considerar a possibilidade de uma cestaria ou pelo menos de uma

camada de vegetais embaixo do sepultamento.

Por fim somente um indivíduo estava presente nesse sepultamento, e apresentava características de um adulto, não sendo possível estimar o sexo. Pequenos blocos de argila amarela estavam relacionados a alguns fragmentos de ossos.

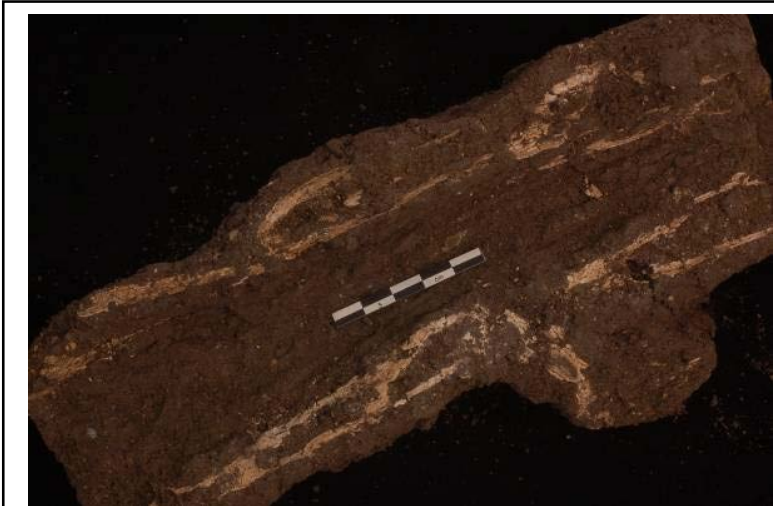

Figura 30: Ossos do sepultamento XII, estado avançado de decomposição. Grande diferença com o material retirado em 2001.

Figura 31: Foto do Crânio em processo de escavação. Retirado em 2001.

\begin{tabular}{|l|l|l|l|}
\hline Indivíduo & Idade & Sexo & Observações \\
\hline A & Adulto & - & - \\
\hline
\end{tabular}




\section{SEPULTAMENTO X}

Sepultamento (ver figura 32) retirado em pequenos blocos em 2001, mas só foi analisado em 2007.

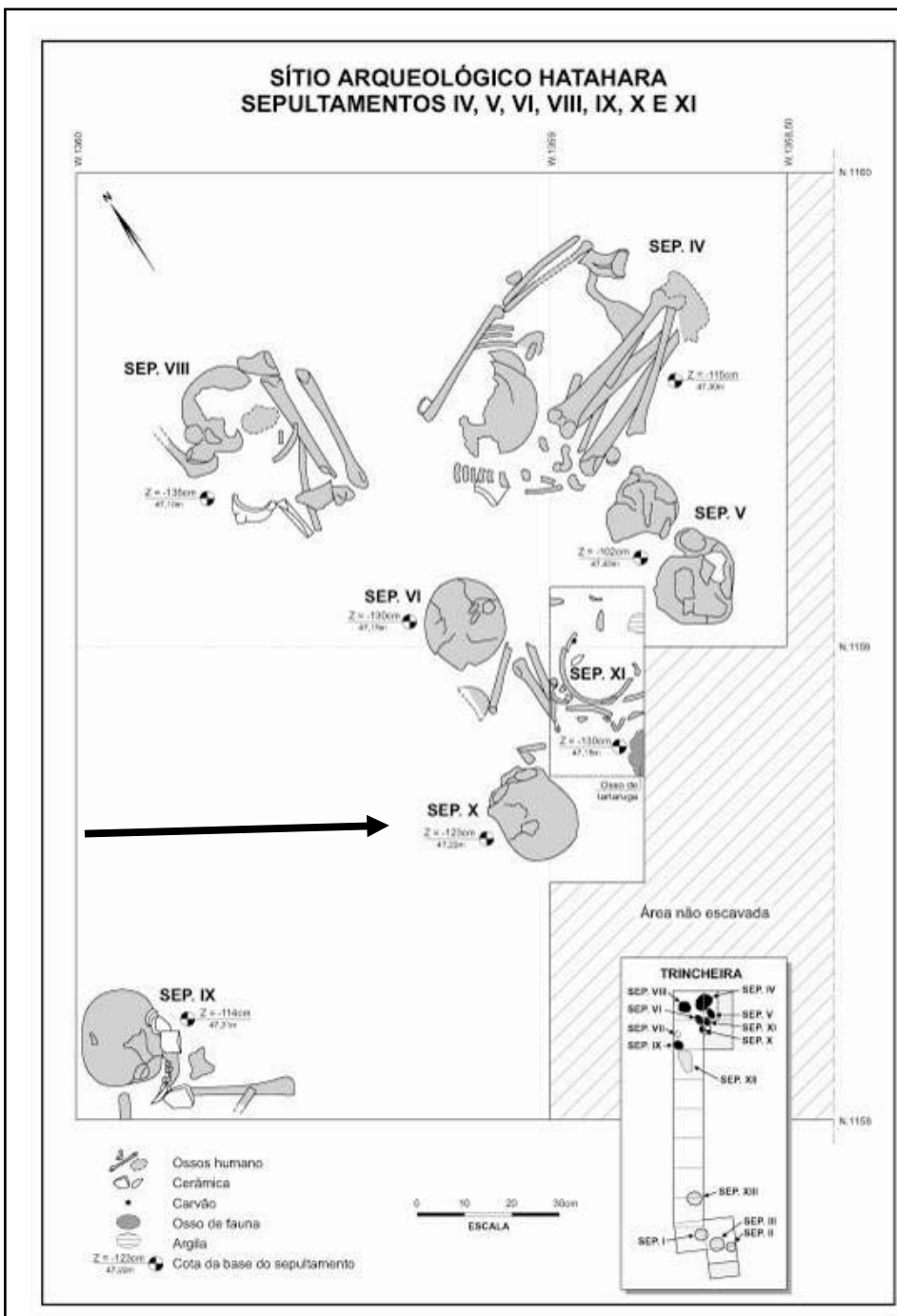

Figura 32: Detalhe dos sepultamentos escavados em 2001. Seta indica sepultamento X. Fonte: PAC.

\section{1- Localização}

Sepultamento

encontrado entre as quadras N1159W1359 e N1159W1360, a 98cm de profundidade. Ele estava na mesma área onde vários outros sepultamentos foram encontrados e existe a possibilidade de que ele não tenha sido bem delimitado em campo, devido à falta de marcadores visuais nítidos (como os limites de uma cova). Sendo assim o resultado parece ser partes de sepultamentos diferentes

associados retirados como um sepultamento.

\section{2- Descrição}

Estão associados ossos de pelo menos dois indivíduos nesse sepultamento, um infantil (indivíduo A) e o outro adulto (indivíduo $B$, ver

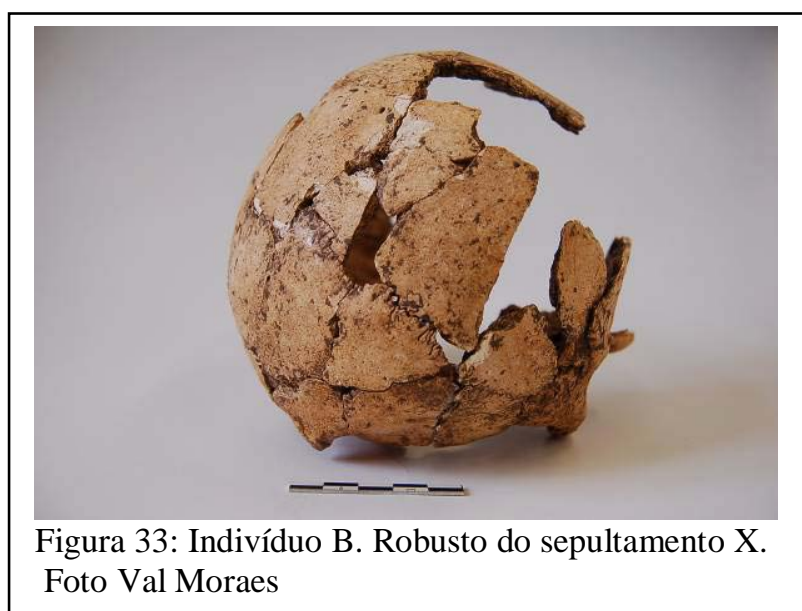


figura 33). O sepultamento de criança parece ser o principal (ou menos perturbado), pois nele há vários ossos associados (fêmur, tíbia, mandíbula, etc.) que têm aparentemente a mesma idade. Além da dificuldade de determinar os indivíduos, há um agravante. Nas fotos e nos croquis não é possível distinguir os limites desse sepultamento e do que foi chamado sepultamento XI.

Em laboratório percebeu-se que a tíbia e o fêmur esquerdo do indivíduo A estavam em proximidade anatômica formando um “x”, com a mandíbula por cima do fêmur. Com essas informações não é possível determinar se o sepultamento era primário ou secundário, mas não parece haver dúvidas sobre o fato de ser um sepultamento.

A área onde esse sepultamento foi encontrado sofreu fortes distúrbios, provavelmente devido a uma reutilização contínua e constante. Outra possibilidade é que ossos encontrados "soltos” no sedimento sejam provenientes de outras áreas e vieram com a terra que formou a camada monticular.

\begin{tabular}{|l|l|l|l|}
\hline Indivíduo & Idade & Sexo & Observações \\
\hline A & Infantil & - & $\begin{array}{l}\text { Menos de 6 anos } \\
\text { (Buikstra e Ubelaker) }\end{array}$ \\
\hline B & Adulto & - & Robusto \\
\hline
\end{tabular}

\section{DEPÓSITO SECUNDÁRIO XI}

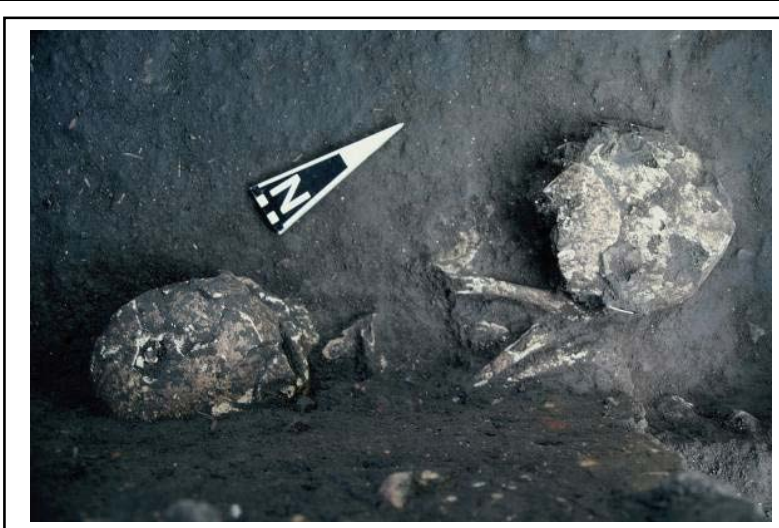

Figura 34: Depósito XI. Fonte: PAC.

\section{1- Localização}

Este depósito (ver figura 34) foi encontrado entre as quadras N1159W1359 e N1160W1359, a $105 \mathrm{~cm}$ de profundidade. Os limites entre esse depósito e os sepultamentos X e VI não são claros nas fotos e nos croquis. A área desse depósito foi intensamente remexida.

\section{2- Descrição}

Esta concentração de ossos parece ser um depósito secundário. Ele está 


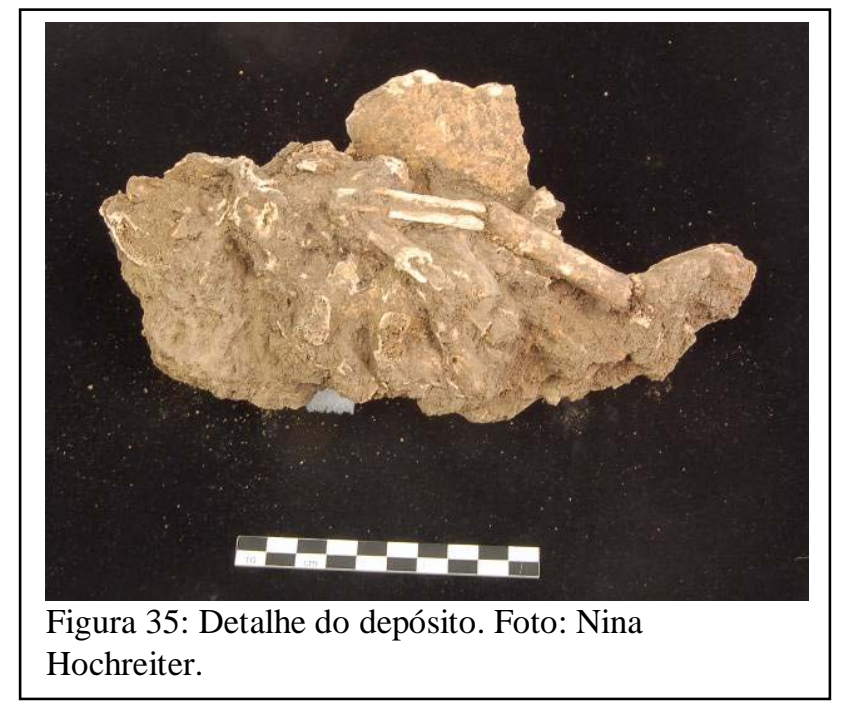

extremamente perturbado e fragmentado, não apresentando conexões e sem organização interna aparente.

Apesar do aspecto caótico desse depósito, o conteúdo não é aleatório, pois somente a parte superior do corpo está presente no depósito (crânio, vértebras, costelas e um metacarpo, ver figura 35). Como hipótese, pode-se pensar que este depósito provem do impacto de um sepultamento primário. A perturbação teria se dado na parte superior de um esqueleto, talvez recolhendo terra para formar o montículo ou durante a escavação de outra fossa, no depósito estariam os ossos juntos, mas sem conexão visível, e muito fragmentados.

Todos os fragmentos pareciam ser de adulto, talvez do mesmo indivíduo.

\begin{tabular}{|l|l|l|l|}
\hline Indivíduo & Idade & Sexo & Observações \\
\hline A & Adulto & - & $\begin{array}{l}\text { É provável que todos os } \\
\text { ossos sejam do mesmo } \\
\text { indivíduo }\end{array}$ \\
\hline
\end{tabular}

\section{SEPULTAMENTO XIII}

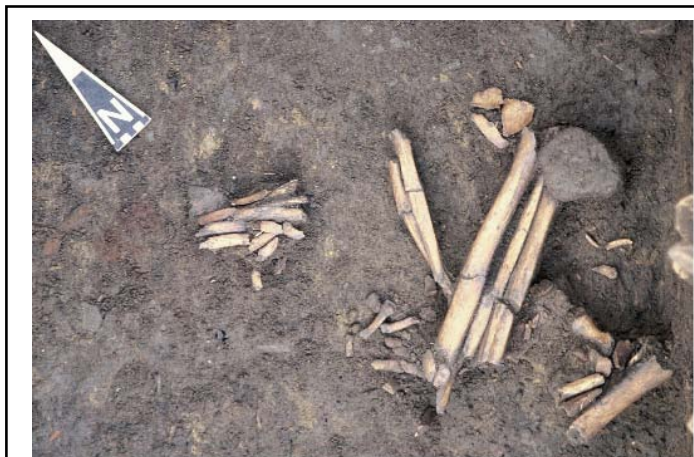

Figura 36: Foto do sepultamento XIII. Foto: R. Bartolomucci.

\section{1- Localização}

Esse sepultamento foi encontrado em 2002 entre as quadras N1153W1360 e N1154W1360, ele é o segundo sepultamento mais profundo da coleção, a profundidade da base era de $125 \mathrm{~cm}$ (ver figura 36).

No trabalho de Machado (2005)

encontra-se uma descrição da posição estratigráfica e uma hipótese sobre esse sepultamento: 


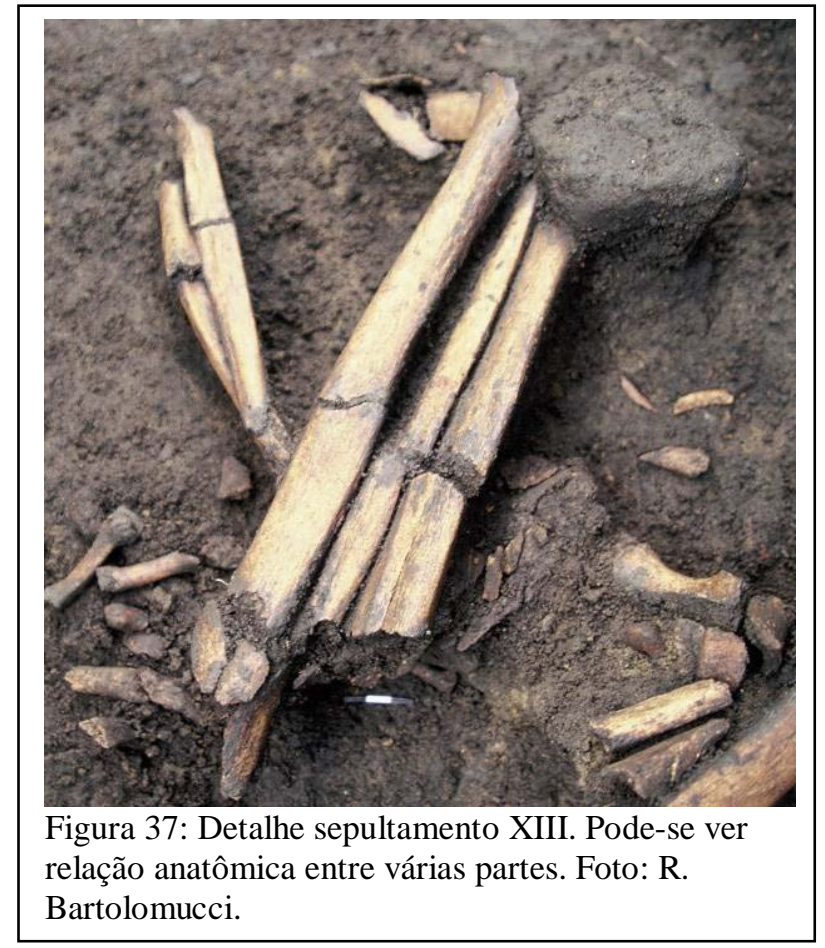

- Ao analisarmos a estratigrafia da unidade de escavação N1153 W1360 e da unidade N1154 W1360, podemos notar que a camada IVA, correspondente ao piso cerâmico de construção do montículo artificial está localizada no nível 9 e o sepultamento encontrado apenas no nível $14 \ldots$ os sepultamentos [do bolsão 2] estão localizados diretamente abaixo da camada cerâmica, enquanto no sepultamento XIII observamos $40 \mathrm{~cm}$ de distanciamento vertical. É interessante notarmos, no entanto, a presença de ossos humanos no meio $e$ diretamente abaixo da camada IVA, que não estão presentes no restante das unidades escavadas. ... A localização desse sepultamento próximo à camada II.... hipótese, o sepultamento XIII já existiria no momento de construção do montículo e teria sido perturbado com a movimentação do sedimento da camada III (na qual ele está inserido) para uma espécie de "terraplanagem" que serviu de base para a colocação dos fragmentos cerâmicos (Machado 2005:134).

\section{2- Descrição}

No momento e após a descoberta deste sepultamento, os arqueólogos não tinham certeza sobre o fato de ser ou não um sepultamento. Pelas fotos, a organização dos ossos longos parece indicar um sepultamento primário com a perna fletida (fêmur, tíbia e fíbula visíveis), ossos do antebraço e costelas em seqüência anatômica (ver figura 37). É certo que nesse caso a perturbação foi intensa, entretanto os vestígios que sobraram estavam relativamente bem conservados, um fator que pode ter ajudado nessa conservação é a robustez do indivíduo, que era importante.

Como mencionado anteriormente havia um fragmento de fauna com marcas de 
folha impressa junto com um bloco de ossos retirados (PN 20015) (ver figura 24).

\begin{tabular}{|l|l|l|l|}
\hline Indivíduo & Idade & Sexo & Observações \\
\hline A & Adulto & - & Robusto \\
\hline
\end{tabular}

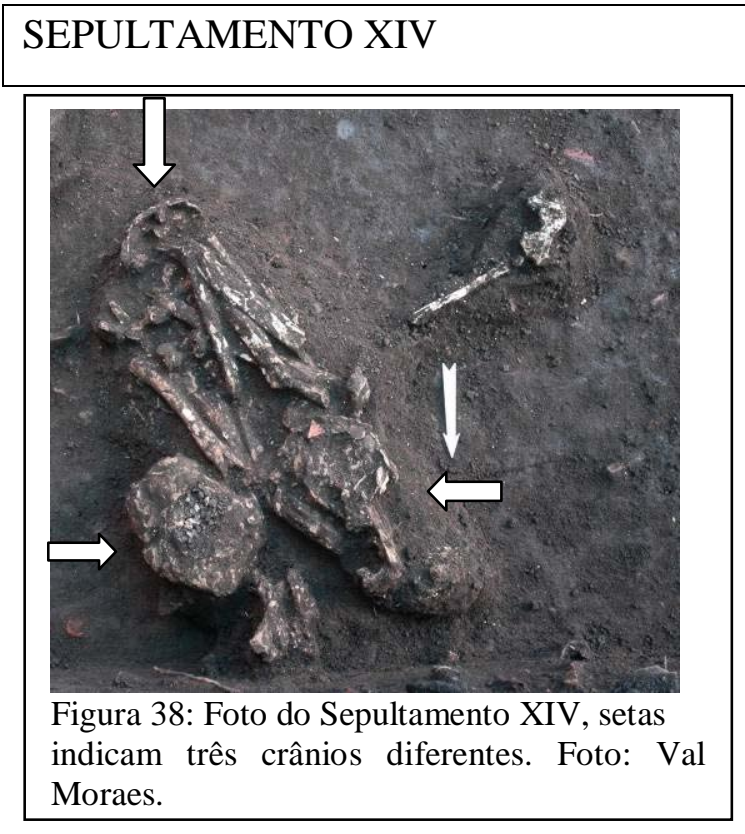

\section{1- Localização}

Após a campanha de 2002 a escavação do M.I só foi retomada em 2006. Nesse momento, na quadra N1160W1358, a partir dos $75 \mathrm{~cm}$ de profundidade, no quadrante nordeste uma quantidade importante de ossos humanos foi descoberta. Este sepultamento só ficou totalmente evidenciado a $83,5 \mathrm{~cm}$ de profundidade (ver figura 38). Grandes fragmentos de cerâmica pareciam associados ao sepultamento no seu extremo sul (PN 20209), mas dúvidas subsistem sobre suas relações com o sepultamento. Esse sepultamento parecia estar dentro da primeira camada de construção do montículo IVA e ocupava um espaço de aproximadamente 70 x $40 \mathrm{~cm}$ (sem considerar os ossos separados a oeste).

\section{2- Descrição}

A organização dos ossos é típica de sepultamentos secundários e múltiplos, com os ossos longos de adulto depositados em feixe e com ossos pequenos faltando (falange, carpo, tarso, etc.). Ossos longos do indivíduo infantil foram colocados ao norte do crânio, mais a leste (PN 20215.13). Três crânios foram colocados com esse feixe: um a leste, um ao sul e um sobre os ossos. Alguns ossos (uma diáfise de osso longo grande e um osso coxal) foram encontrados a oeste da concentração do sepultamento. Isso pode ter ocorrido durante o processo de deposição ou por ação de algum animal (tipo tatu). Os ossos foram agrupados após um período de decomposição total (ou quase das partes moles. Não havia evidência de queima sobre 
os ossos.

Os ossos estavam na maioria dos casos, mal conservados. Foram necessárias três etapas de desmontagem para retirá-los. O sedimento peneirado acima dos níveis correspondendo ao sepultamento proporcionou uma grande quantidade de ossos, dentes humanos e de fauna.

\begin{tabular}{|l|l|l|l|}
\hline Indivíduo & Idade & Sexo & Observações \\
\hline A & Adulto & - & Robusto \\
\hline B & Adulto & - & Conservação péssima \\
\hline C & Infantil & - & $\begin{array}{l}\text { Os dentes encontrados no } \\
\text { crânio e ao redor indicam } \\
\text { que todos os decíduos } \\
\text { tinham eclodido, mas } \\
\text { nenhum permanente. }\end{array}$ \\
\hline
\end{tabular}

\section{DEPÓSITO SECUNDÁRIO XV}

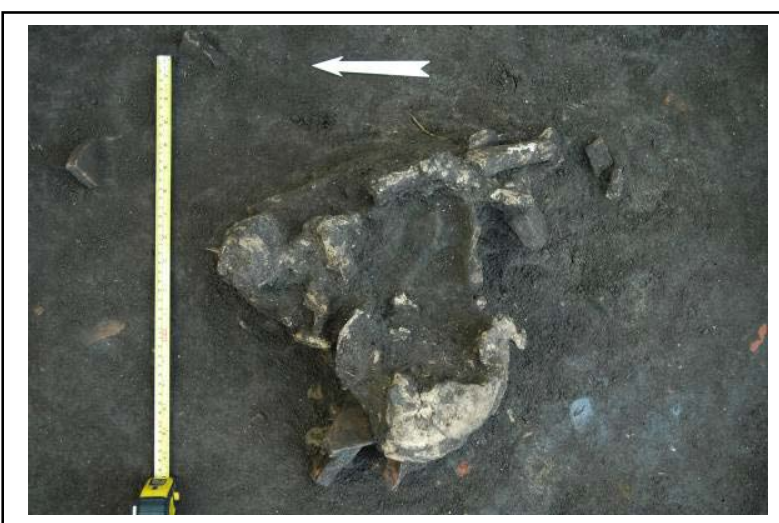

Figura 39: Foto do depósito XV. Foto: Claide Moraes.

\section{1- Localização}

Depósito encontrado em 2006 no oeste da quadra N1159W1357 a partir de $85,5 \mathrm{~cm}$ de profundidade, mas que só terminou de ser evidenciado aos $98 \mathrm{~cm}$.

\section{2- Descrição}

Essa concentração de ossos foi

considerada como depósito. Material cerâmico, aparentemente da fase Paredão, ossos humanos e fauna estavam misturados. Os ossos encontrados estavam muito fragmentados, com pelo menos dois indivíduos presentes e não eram muito numerosos (ver figura 39 e 40). Não há evidências de queima.

Logo antes de aparecer o

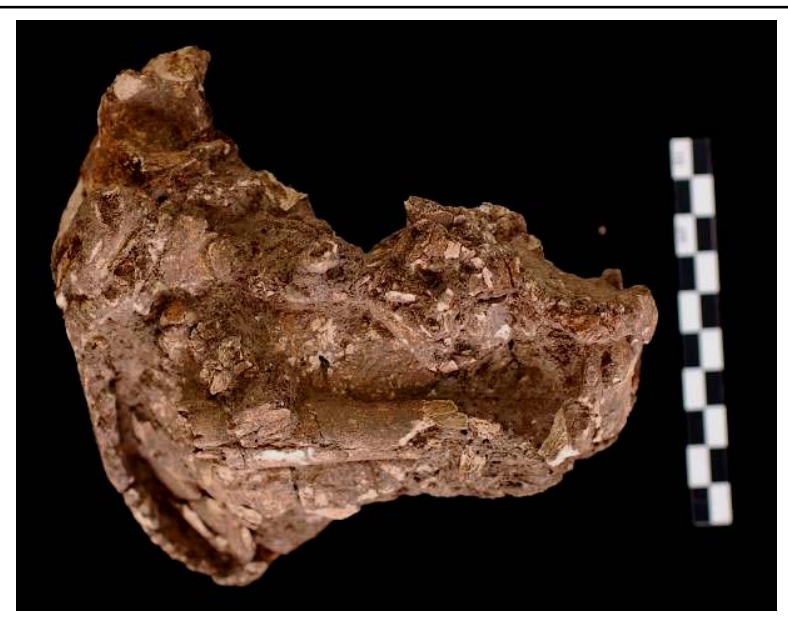

Figura 40: Detalhe do depósito XV. 
sepultamento, houve uma redução drástica na quantidade de cerâmica, parecendo ser o começo da camada de construção do montículo. Bioturbações e lentes amarelas de solo também aparecem no nível desse depósito. Outra diferença em relação aos níveis precedentes é a compactação do solo, que fica mais acentuada.

Parte dos ossos encontrados são de um adulto. Não foi possível determinar sexo ou idade com o material. Além dos ossos de adultos existem vários dentes decíduos e germes dentários associados e fragmentos de crânio infantil.

Duas hipóteses possíveis para esse depósito são: a primeira é ele ser o resultado de um impacto sobre um sepultamento múltiplo, e uma parte dos ossos foram levados a esse local; a segunda hipótese é a de que essa concentração seja o resto de um sepultamento secundário extremamente perturbado pela construção do montículo ou pelo próprio ato de fazer novas covas. As lentes de solo amarelo podem indicar tanto uma coisa quanto a outra, pois elas são indícios de perturbações no latossolo.

Essas duas possibilidades explicariam o alto nível de perturbação encontrado.

\begin{tabular}{|l|l|l|l|}
\hline Indivíduo & Idade & Sexo & Observações \\
\hline A & Adulto & - & $\begin{array}{l}\text { É provável que todos os } \\
\text { ossos sejam do mesmo } \\
\text { indivíduo }\end{array}$ \\
\hline B & Infantil & - & $\begin{array}{l}\text { É provável que todos os } \\
\text { ossos sejam do mesmo } \\
\text { indivíduo }\end{array}$ \\
\hline
\end{tabular}

\section{SEPULTAMENTO XVI}

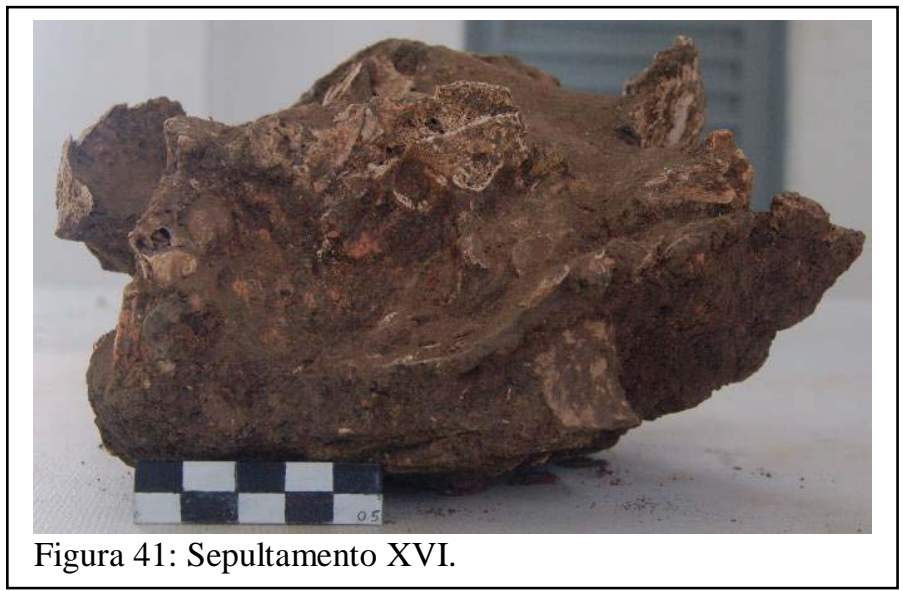

1- Localização

Sepultamento encontrado e escavado em 2006 (ver figura 41 e 42). Este sepultamento foi encontrado na quadra N1158W1357 entre 85 e $95 \mathrm{~cm}$ de profundidade, no perfil sul da unidade de escavação. Teve-se que abrir mais $50 \mathrm{~cm} \mathrm{x} 1 \mathrm{~m}$ em direção sul e escavar mais $10 \mathrm{~cm}$ para evidenciá-lo por completo. 


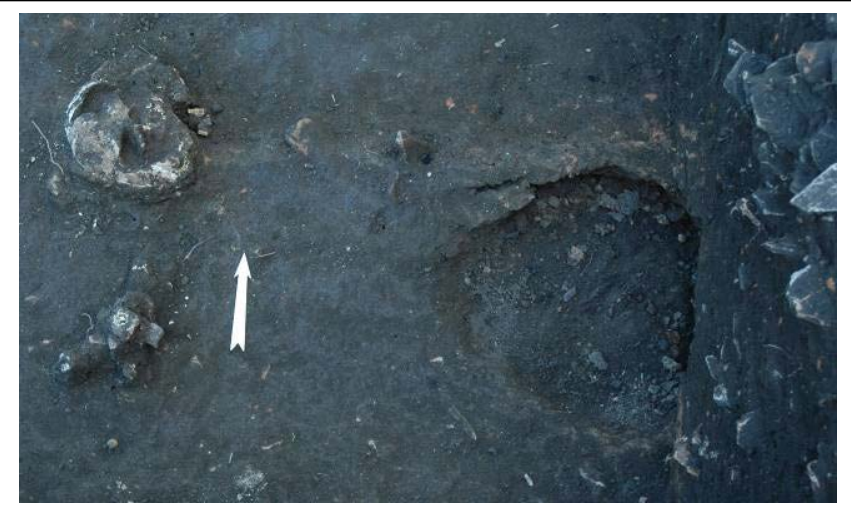

Figura 42: Sepultamento XVI perto de bioturbação.

\section{2- Descrição}

No momento da descoberta, o sepultamento foi definido essencialmente por um crânio e alguns ossos fragmentados (PN 20915.1). Durante a limpeza em laboratório, foi percebido que, abaixo do crânio havia fragmentos de diáfises. Não há conexão entre os ossos, ele é secundário (ver figura 41). É provável que esse sepultamento estivesse in situ quando encontrado, pois o crânio parece ter sido depositado sobre os ossos longos, com a mandíbula próxima. Esse sepultamento apresenta muitas perturbações. O crânio está muito fragmentado e partes estão faltando, partes de maxila e de mandíbula estão ao redor do crânio, nem sempre respeitando a lógica anatômica (ver figura 43).

$$
\text { Vale a pena }
$$

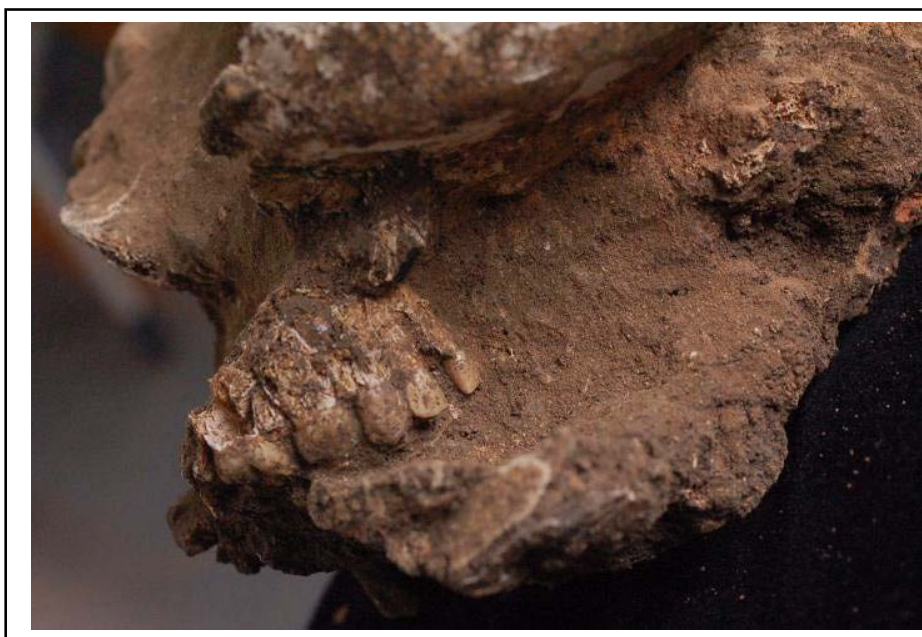

Figura 43: Detalhe da maxila.

mencionar que ao sudeste foi encontrado evidências de um grande formigueiro (ver figura 42). Além disso, no mesmo local há presença de terra queimada e grande quantidade de carvões indicando o lugar de uma fogueira. Esses elementos estavam no mesmo nível à aproximadamente $40 \mathrm{~cm}$ do sepultamento em questão. Não se sabe há contemporaneidade entre o sepultamento e a fogueira, pois não conhecemos os limites da cova para saber o quão profunda ela era.

\begin{tabular}{|l|l|l|l|}
\hline Indivíduo & Idade & Sexo & Observações \\
\hline A & Infantil & - & Aproximadamente 3 anos \\
\hline
\end{tabular}




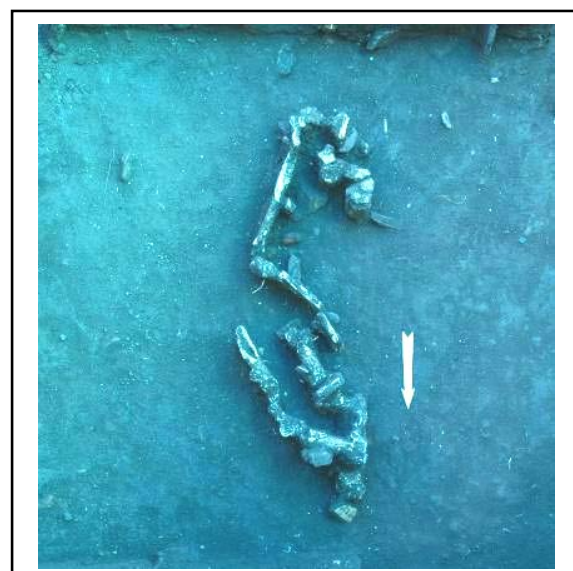

Figura 44: Foto do Sepultamento XVII. Foto: Val Moraes.

\section{1- Localização}

Esse sepultamento foi encontrado e escavado em 2006. É possível que parte dele já tivesse sido escavada em 2001, pois ele foi cortado nesse momento (ver figura 44). Entretanto, a associação com o sepultamento V não é evidente pelas fotos e croquis. Também deve-se atribuir uma parte da deterioração do material a exposição às intempéries durantes cinco anos.

Esse sepultamento foi encontrado no meio da quadra N1160W1359 entre $82 \mathrm{~cm}$ e $85 \mathrm{~cm}$ de profundidade. Alguns cascos de tartaruga e pedaços de laterita estão misturados. Os ossos estão muito deteriorados. Vários pequenos blocos foram retirados, sendo que a maior parte dos fragmentos identificados pertence a ossos longos e alguns ossos planos.

\section{2- Descrição}

Esse sepultamento está com uma conservação muito ruim, mas pelo o que se percebeu não havia conexões ou proximidades anatômicas significativas, indicando um contexto secundário. Esse sepultamento parece contido dentro de uma cova ampla, os ossos não estão muito amontoados, mas visto a conservação e a fragmentação alguns ossos podem ter se desintegrado. Esse é um dos poucos sepultamentos encontrados em 2006 que corresponde a descrição de Machado (2005), que menciona laterita. Em sua dissertação a pesquisadora descreve os contextos dos sepultamentos como estando frequentemente acompanhados por fragmentos de cerâmica paredão, lateritas e manchas amarelas. Em 2006 e 2008 encontramos essas associações mas sem muita freqüência.

O indivíduo em questão parece ser um adulto. Não foi possível determinar o sexo.

\begin{tabular}{|l|l|l|l|}
\hline Indivíduo & Idade & Sexo & Observações \\
\hline A & Adulto & - & \\
\hline
\end{tabular}




\section{DEPÓSITO SECUNDÁRIO XVIII}

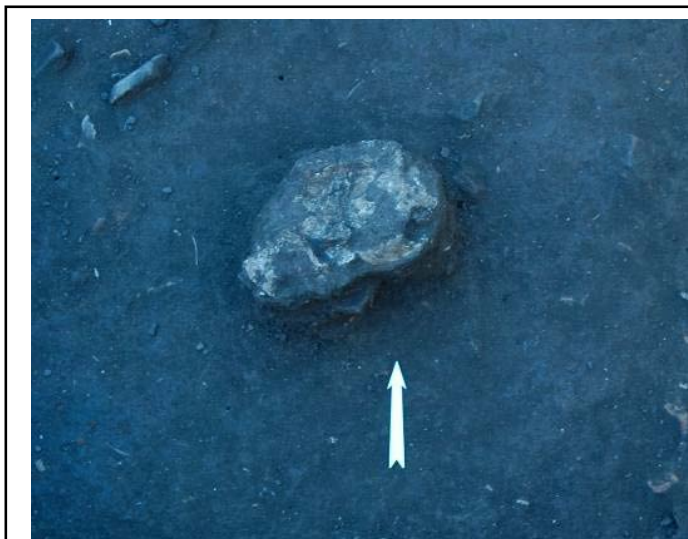

Figura 45: Foto do depósito XVIII.

\section{1- Localização}

Essa concentração (ver figura 45) foi encontrada em 2006, na quadra N1157W1359, a 73cm de profundidade. Está localizada logo abaixo de uma concentração de cerâmicas orientadas horizontalmente (possivelmente o primeiro “piso” de construção do montículo), junto

com esse “piso” havia também uma estrutura em argila queimada.

\section{2- Descrição}

Após verificações em campo e em laboratório acredita-se que essa concentração óssea não seja um sepultamento e sim um depósito secundário, pois o crânio que restou está muito deteriorado e fragmentado, os dentes vistos em campo próximos não estavam em posição anatômica e, sim soltos por cima do crânio. Outros dentes foram encontrados durante a limpeza, que faziam parte do maxilar. Não havia mais ossos próximos.

Essa concentração é oriunda da movimentação de terra ocorrida pelo processo de ocupação montículo, escavação de novas covas e/ou buracos para feições e esteio. Ele não parece ter sido colocado naquele local propositalmente.

O crânio talvez pertença a um adulto, os dentes estão muito

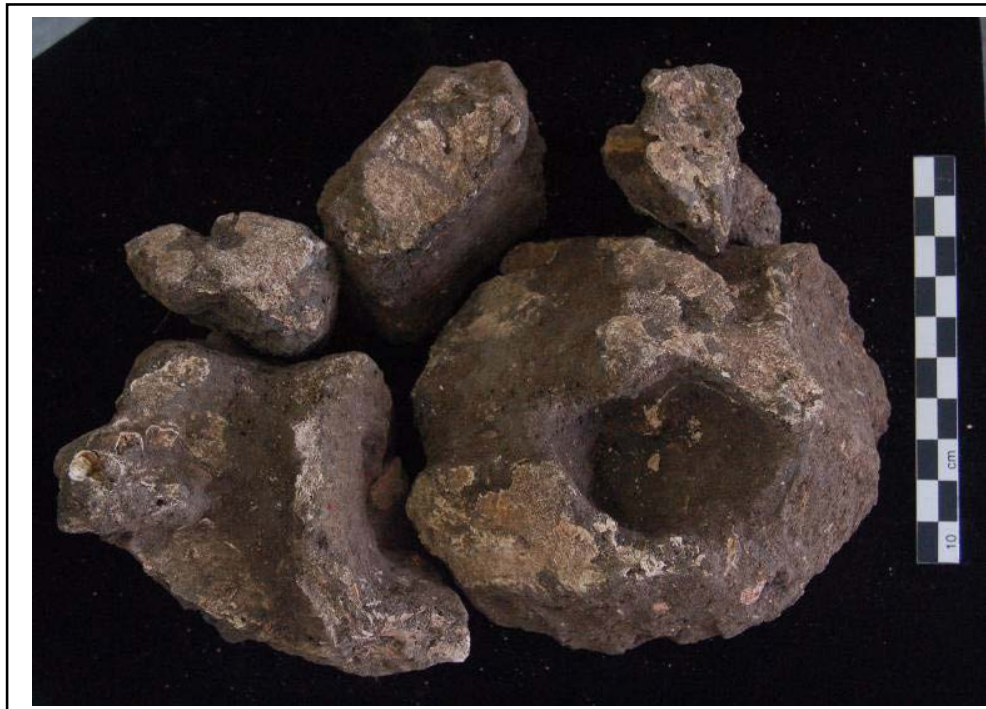

Figura 46: Detalhe do depósito XVIII. quebrados para estimar a idade (ver figura 46). 


\begin{tabular}{|l|l|l|l|}
\hline Indivíduo & Idade & Sexo & Observações \\
\hline A & Adulto & - & $\begin{array}{l}\text { Todos os elementos } \\
\text { ósseos devem pertencer a } \\
\text { um mesmo indivíduo }\end{array}$ \\
\hline
\end{tabular}

\section{SEPULTAMENTO XIX}

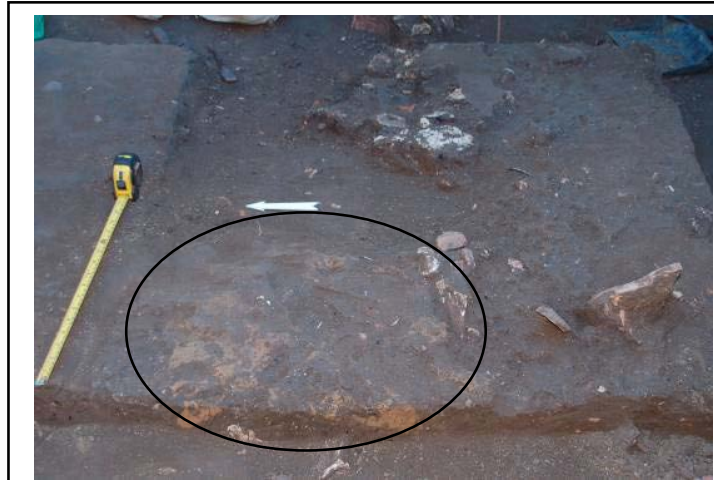

\section{1- Localização}

O sepultamento estava embaixo de uma mancha de argila amarela (ver figura 47) e foi encontrado em 2006 nas quadras N1158W1358 e N1158W1359, este apareceu entre $92,5 \mathrm{~cm}$ e $115 \mathrm{~cm}$ de

Figura 47: Mancha amarela sobre o sepultamento XIX. profundidade. O espaço ocupado pelo corpo é de aproximadamente $50 \mathrm{~cm}$ na

direção norte-sul, $50 \mathrm{~cm}$ na direção leste-oeste e 22,5 cm de espessura (ver figura 48). A leste desse sepultamento estava a feição 16, com cerâmica e fauna (ver figura 47).

\section{2- Descrição}

$\mathrm{O}$ indivíduo estava com as pernas fletidas entre a posição de

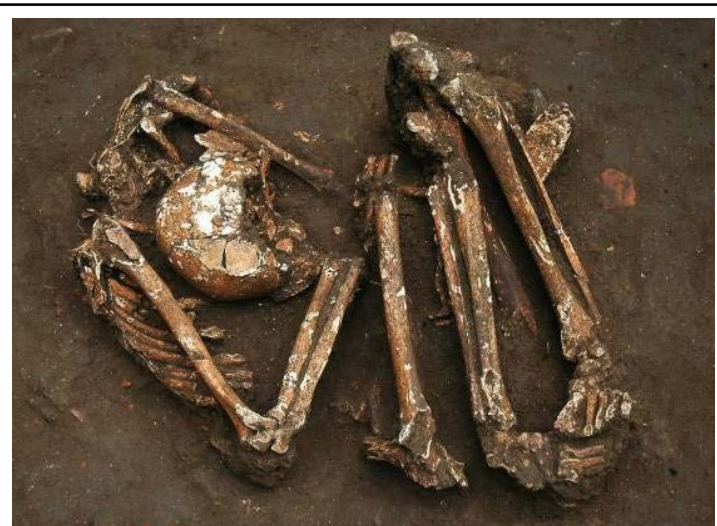

Figura 48: Foto do sepultamento XIX. Foto: Val Moraes.

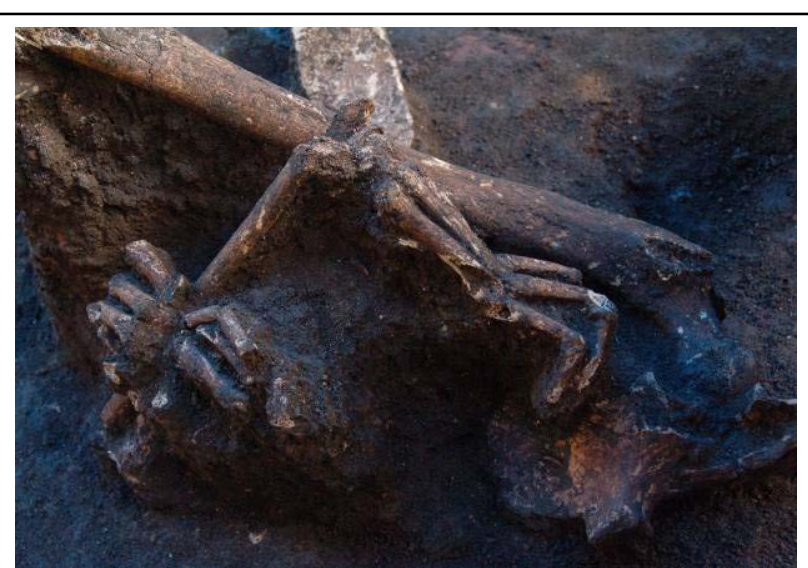

Figura 49: Detalhe das mãos do sepultamento XIX.

decúbito dorsal e lateral. As mãos se encontravam cruzadas perto do joelho. Pela quantidade de conexões estritas no indivíduo inteiro, pelo seu posicionamento e pela presença de quase todos os ossos pequenos (por exemplo falanges distais da mão, ver figura 49) é possível afirmar que a 
decomposição se fez in situ. Se houve algum tempo de exposição do corpo antes do enterramento, este foi curto. Não há indícios de um segundo indivíduo na cova. Restos faunísticos estavam associados.

As articulações lábeis (articulation labile em francês, como o carpo, as falanges em geral, etc.) permaneceram associadas (ver figura 50). Não havia espaço vazio (original ou secundário) embaixo da mão esquerda o que significa que a sedimentação foi relativamente rápida e que as mãos estavam perto da base da cova. O espaço onde o crânio caiu deve ter sido criado durante a decomposição.

A verticalização das clavículas e escápulas sugere uma compressão importante na altura dos ombros, ao ponto que o úmero direito aparece em posição postero-lateral. Também constatou-se a verticalização da escápula direita, o que indica que não havia espaço vazio atrás do indivíduo e que suas costas encostavam em uma parede (de cova). A compressão pôde ser observada nos pés, alguns metatarsos estavam visíveis pela face supero-distal, indicando um efeito de parede, pois o normal, é que se houvesse espaço, eles caíssem.

O crânio do sepultamento XIX foi parcialmente esmagado após ter sido depositado na cova. O buraco criado é circular e poderia corresponder a um buraco de poste/estaca. Quando essa ação ocorreu, o crânio já havia caído e o cérebro se decomposto, alguns fragmentos ficaram na vertical grudados na terra, indicando que esta já estava presente (ver figura 50).

A conservação desse sepultamento é muito superior às dos sepultamentos secundários descobertos em 2006. Além disso, a argila amarela, utilizada como

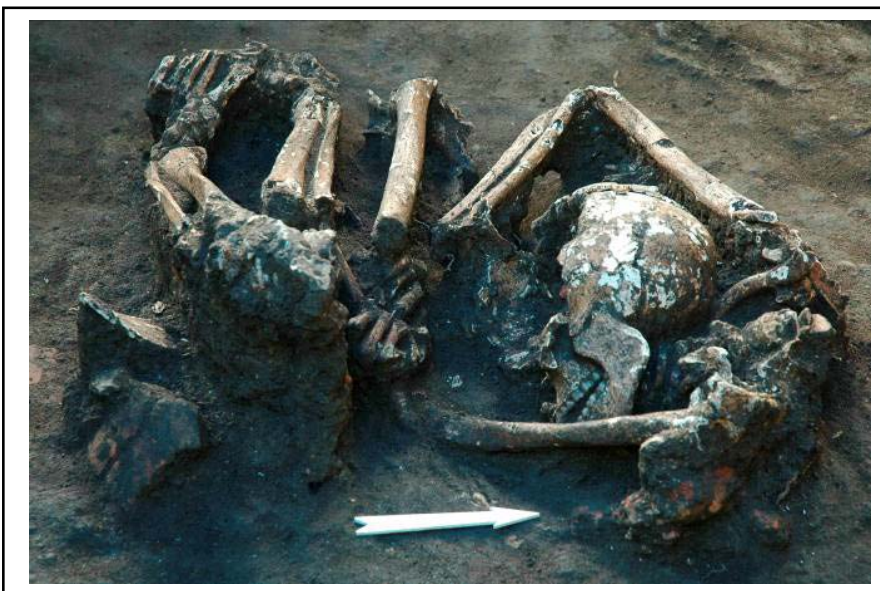

Figura 50: Sepultamento XIX. Foto: Val Moraes. marcador do sepultamento, é uma indicação sobre as práticas de enterramento clara. Até esse momento somente manchas amarelas e o contexto perturbado do sepultamento III tinham sido encontrados.

$\mathrm{O}$ individuo encontrado não era robusto. A dentição estava em bom estado de conservação. Todo o lado esquerdo dos dentes 


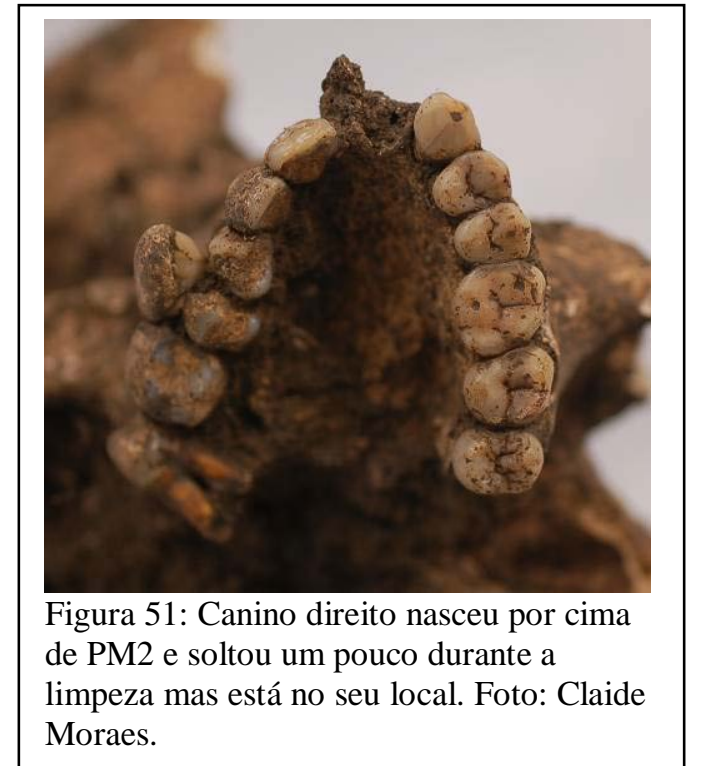

superiores e inferiores estava tomado por tártaro, que por vezes cobre até a face oclusal. Este lado também quase não apresenta desgaste, o que está em grande contraste com o lado esquerdo. O canino direito nasceu por cima do segundo premolar. É provável que esse indivíduo apresentasse problemas mastigatórios importantes, como mastigação diferencial utilizando apenas um lado (ver figura 51 e

52). Este indivíduo apresenta perda incisivos centrais inferiores em vida, sugerindo talvez a utilização de adomos labiais (Rodrigues-Carvalho e Souza, 1998; Wesolowski, 2007). “O impacto traumático de tais artefatos [adornos] nos tecidos periodontais leva a perdas dentárias, o que é reconhecido na literatura brasileira (Ribeiro, 1993)" (Rodrigues-Carvalho e

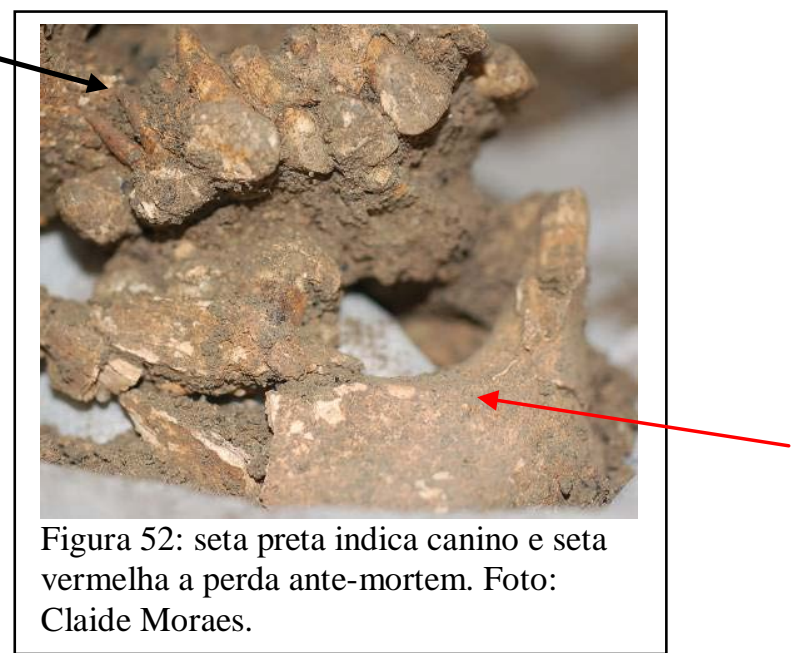
Souza, 1998: 39). Este é o único indivíduo até agora identificado com esse tipo de perda.

Ao lado do sepultamento, para leste, estava a feição 16 que parecia acompanhar o sepultamento. Ela não o cortava e nem parecia cortada por ele.

Não foi possível identificar o sexo do indivíduo, entretanto suas características são gráceis, de acordo com a metodologia proposta no Standards (Buikstra e Ubelaker, 1994) levaria a dizer que há fortes chances desse indivíduo ser feminino.

\begin{tabular}{|l|l|l|l|}
\hline Indivíduo & Idade & Sexo & Observações \\
\hline A & Adulto & $\begin{array}{l}\text { Feminino } \\
\text { provável }\end{array}$ & $\begin{array}{l}\text { Presença de desgaste e } \\
\text { tártaro irregular }\end{array}$ \\
\hline
\end{tabular}




\section{SEPULTAMENTO XX}

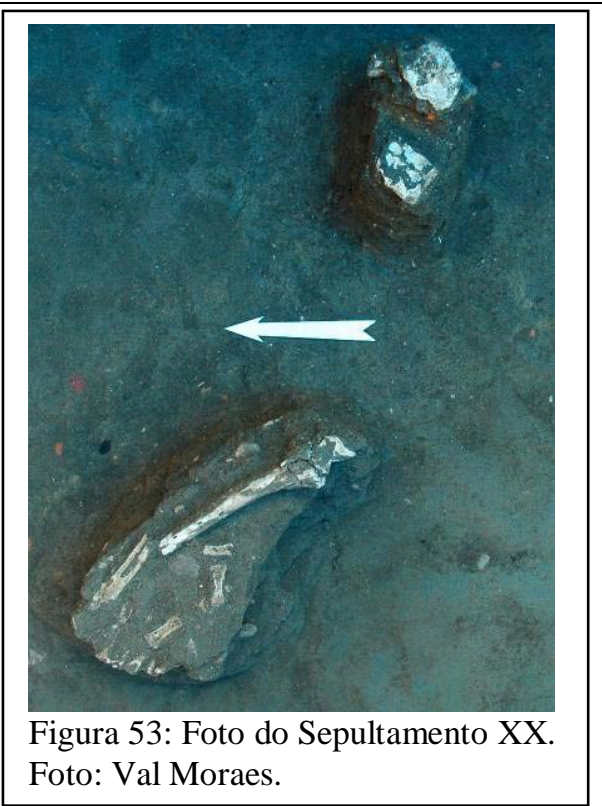

\section{1- Localização}

Sepultamento (ver figuras 53 e 54) encontrado nas quadras N1158W1357 e N1158W1356 SW1/2 entre aproximadamente $96 \mathrm{~cm}$ e $100 \mathrm{~cm}$ de profundidade.

\section{2- Descrição}

Apesar de apenas uma pequena fração desse sepultamento ter sido conservada pode-se afirmar que ele era primário (ou enterrado após curto períod

o de exposição). Parte da mão esquerda foi encontrada em supinação (com a face palmar para cima) sobre um osso plano (escápula ou osso coxal) e ulna E. Na figura 53, pode-se ver que o nível de perturbação é grande e que a conservação do material ósseo é média. É possível que

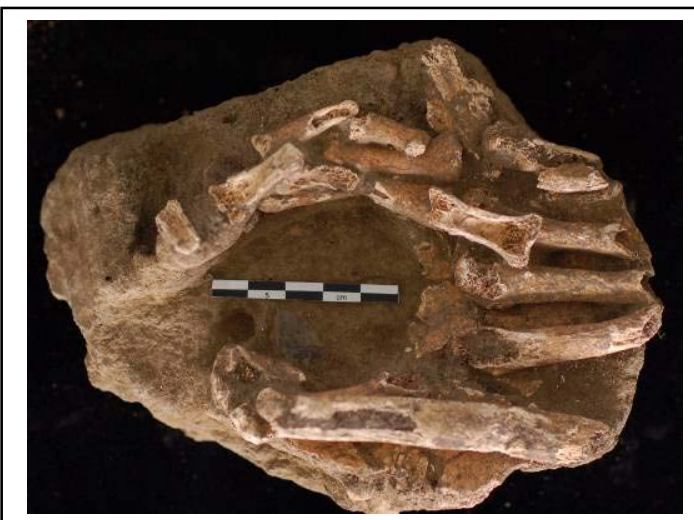

Figura 54: Detalhe da mão. este sepultamento tenha sido perturbado pela abertura de grandes fossas. Isso explicaria porque só parte dele estava preservada. Esse sepultamento é um bom exemplo de preservação diferenciada (parte do esqueleto se preservou enquanto parte desapareceu), parte das perturbações são devido as ações humanas do tipo remeximento de terra, por exemplo logo acima havia uma feição de tamanho importante que pode ser uma das responsáveis pelo impacto. Somente a mão esquerda e alguns outros ossos se preservaram.

Os pontos de ossificação visíveis estavam todos ossificados, portanto este indivíduo deve ter passado da adolescência.

\begin{tabular}{|l|l|l|l|}
\hline Indivíduo & Idade & Sexo & Observações \\
\hline A & Adulto & - & Conservação ruim \\
\hline
\end{tabular}




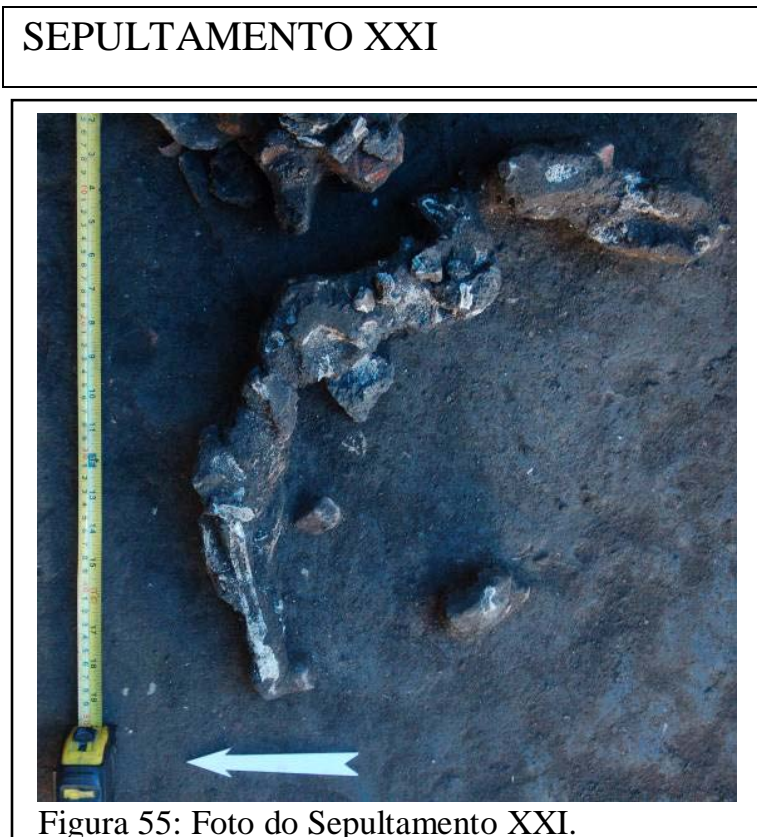

\section{1-Localização}

Este sepultamento (ver figura 55) se encontrava no limite leste da quadra N1159W1357, estava nível 100$110 \mathrm{~cm}$. Muito deteriorado, foi retirado em dois blocos (PN 20619.1 e PN 20619.2).

\section{2- Descrição}

Embaixo de um fragmento da extremidade distal de fíbula direita,

estava o carpo direito com metacarpos em conexão e falanges remexidas e deterioradas. A presença dos ossos da mão em conexão sugere a presença de um sepultamento primário ou pelo menos depositado em uma fase inicial de decomposição (ver figura 56 e 57).

Este sepultamento foi

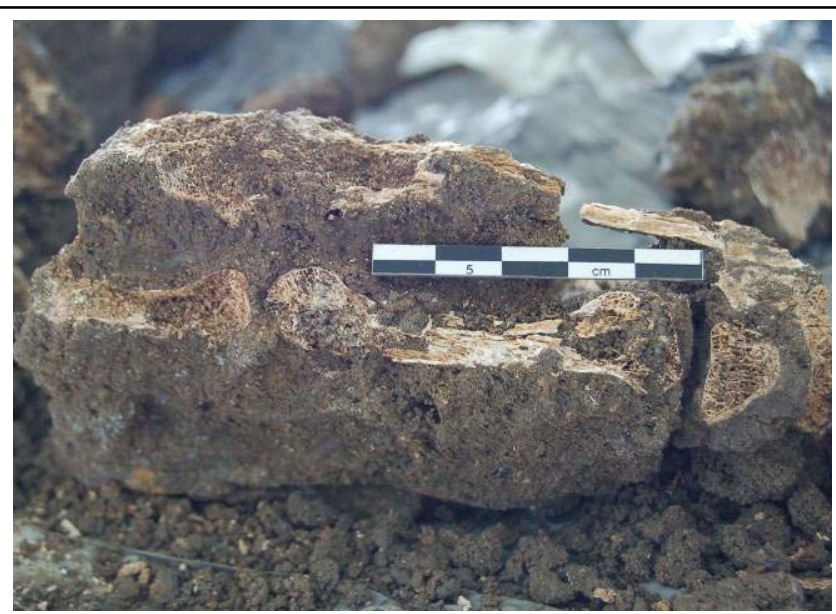

Figura 56: Metacarpo e falanges em conexão. Detalhe do sepultamento XXI.

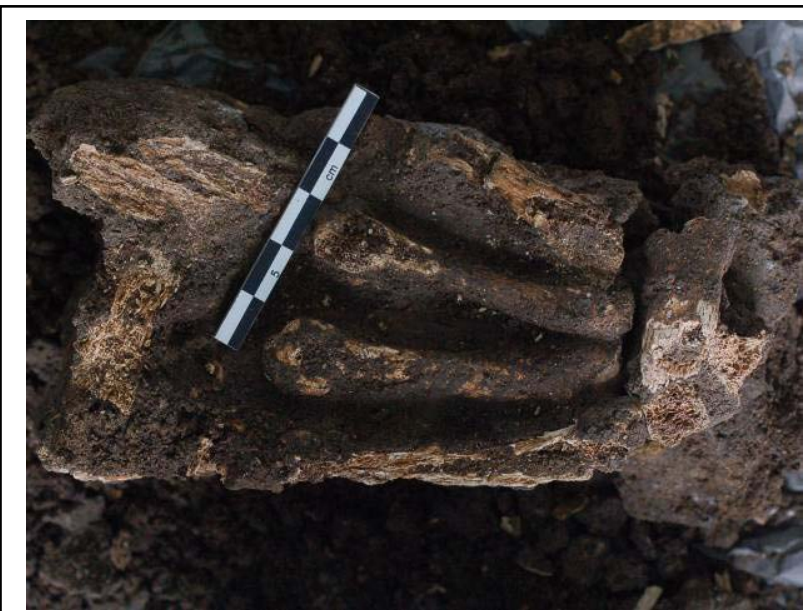

Figura 57: detalhe da mão do sepultamento XXI. intensamente remexido, pois somente parte dele foi encontrada. Como para o sepultamento anterior, é provável que as atividades exercidas sobre 0 montículo (habitação e cemitério) durante vários séculos parecem ter acelerado o processo de decomposição dos ossos A 
importância desses remeximentos de solo é deduzida pelo contexto pouco estruturado. Além disso, processos tafonômicos comuns aos outros sepultamentos também agiram pró e contra a conservação (solo, acidez das raízes, pisos de cerâmica, etc.).

O sepultamento parece estar acima do "piso" de cerâmica identificado por Machado (2005) que em 2006 foi chamado de F17. O indivíduo encontrado parece ser um adulto, se considerarmos que os ossos do metacarpo, as falanges e o carpo já estão ossificados. Fora isso não é possível ter mais indicações.

\begin{tabular}{|l|l|l|l|}
\hline Indivíduo & Idade & Sexo & Observações \\
\hline A & Adulto & - & Conservação ruim \\
\hline
\end{tabular}

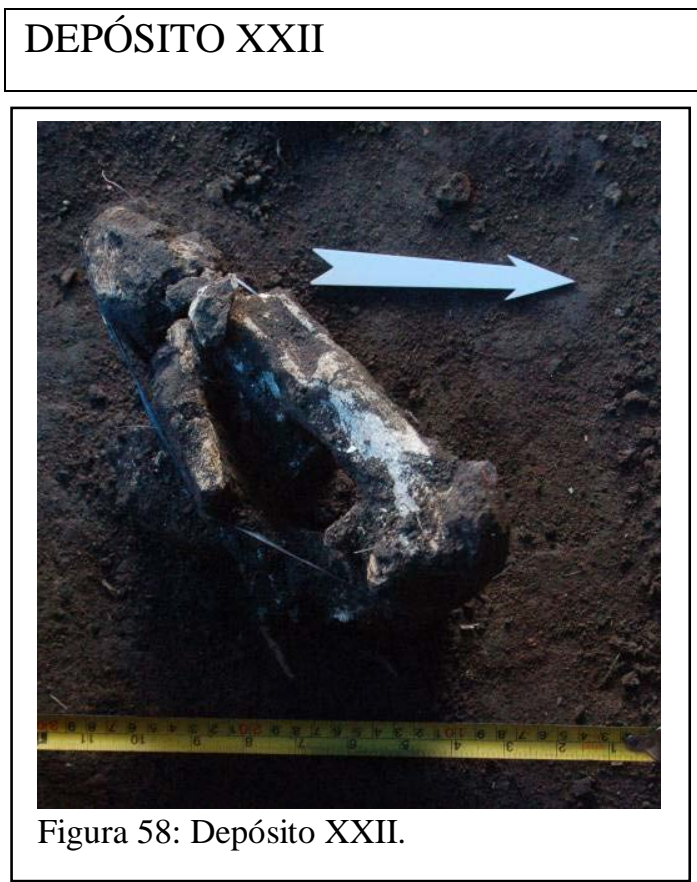

\section{1- Localização}

Descoberto e escavado em 2006, este depósito (ver figura 58) foi retirado em um pequeno bloco. Os ossos estão muito erodidos e de difícil identificação. Ele estava entre as quadras N1160W1356 e N1160W1357 entre 100 e $105 \mathrm{~cm}$ de profundidade.

\section{2- Descrição}

Pouco se preservou, apenas um osso longo e alguns fragmentos. Não é possível determinar idade e sexo. Essa concentração óssea foi considerada como depósito visto a falta de um contexto funerário definido. 


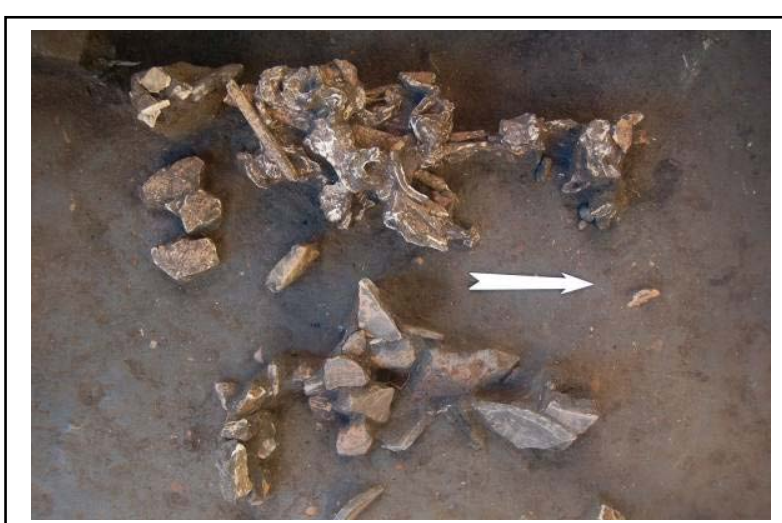

Figura 59: Foto do Sepultamento XXIII.

\section{1- Localização}

Estrutura encontrada e escavada em 2006 na quadra N1160W1359 entre 99cm e $108.7 \mathrm{~cm}$ de profundidade. Uma grande quantidade de ossos não eram humanos, o que foi confirmado em laboratório (ver figura 59). É possível e mesmo

provável que como o sepultamento XVII, esse sepultamento tenha sido impactado pelas escavações de 2001. Infelizmente não se sabe o grau de impacto, pois além das perturbações físicas (sepultamento cortado pelas escavações de 2001), também tem a deterioração do material que pode ser em parte atribuída a exposição às intempéries durante cinco anos.

\section{2- Descrição}

No começo das análises do material ocorreram dúvidas sobre a sua origem, isso se deu pelo fato dos ossos serem muito robustos e diferentes em tamanho dos outros encontrados até 0 momento.

\section{Posteriormente}

percebeu-se que se trata de um indivíduo em um sepultamento secundário - não há conexões ou

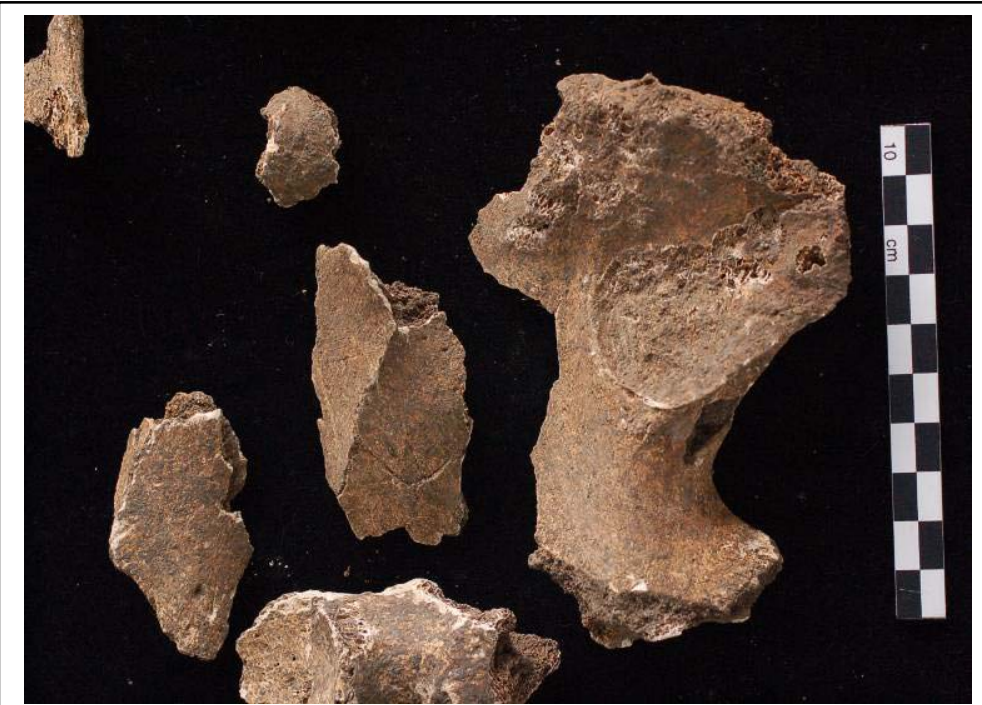

Figura 60: Detalhe do osso coxal do sepultamento XXIII. seqüências anatômicas e percebe-se um reagrupamento dos ossos. Alguns ossos parecem ser de mamíferos, mas fragmentos de casco de tartaruga também estavam presentes. Esse material faunístico ainda deverá ser analisado por especialistas. 
O indivíduo em questão é robusto e grande, quando comparado ao resto da coleção. A estimativa para a idade é de que seja um jovem, entre 18 e 21 anos, pois a cabeça do fêmur não está ossificada, apesar de já ter um tamanho adulto. Além disso, a creta do ilíaco também não se ossificou com o mesmo. Quanto ao sexo, os coxais estão muito incompletos para que os métodos de Bruzek (1991) ou de Buikstra e Ubelaker (1994) sejam aplicados (ver figura 60).

Como pode-se ver pela figura 61 há uma concentração de cerâmica importante logo acima e um pouco mais para leste desse sepultamento - alguns ossos do sepultamento já estão visíveis na foto. Em campo pensou-se que esta concentração podia estar ligada aos “pisos” de

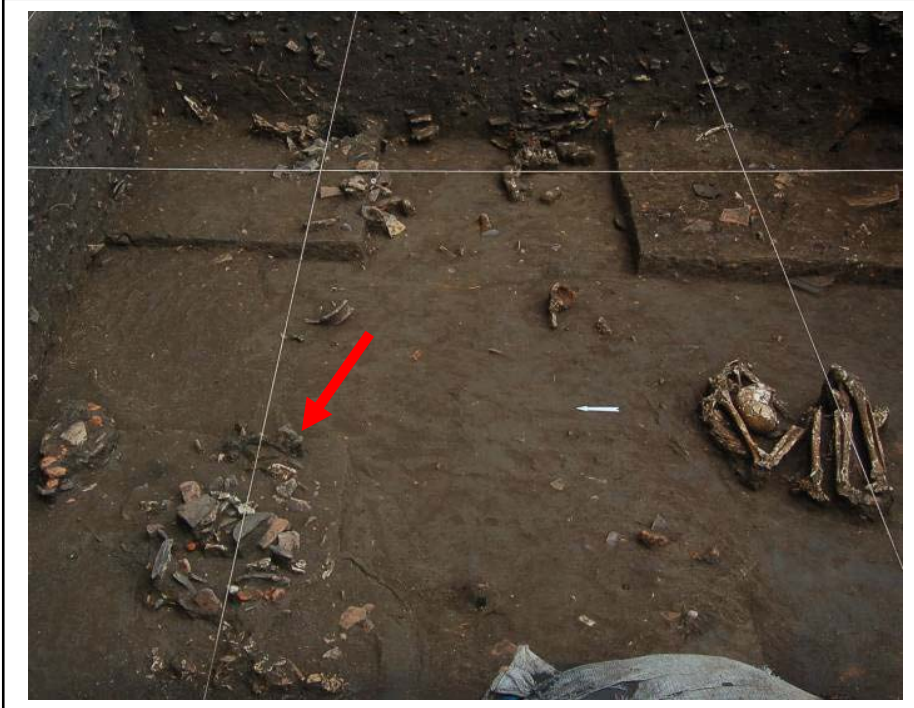

Figura 61: seta vermelha mostra o local do sepultamento XXIII, a leste pode-se ver uma feição. Foto :Val Moraes.

construção identificados por Machado (2005), que nada mais são do que concentrações importantes de cerâmicas utilizadas para erguer o montículo. Por isso recebeu o nome de feição 17. Entretanto, o resultado da reanálise das fotos, das fichas e dos materiais demonstrou que o mais provável é que seja uma feição independente associada ao sepultamento XXIII.

\begin{tabular}{|l|l|l|l|}
\hline Indivíduo & Idade & Sexo & Observações \\
\hline A & $\begin{array}{l}\text { Adulto } \\
\text { jovem }\end{array}$ & - & robusto \\
\hline
\end{tabular}




\section{SEPULTAMENTO XXIV}

\section{1- Localização}

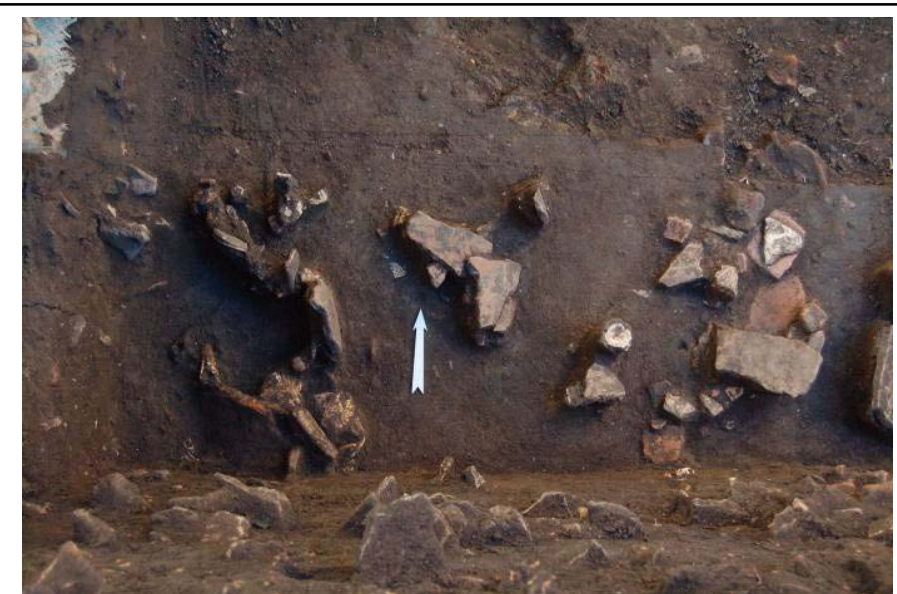

Figura 62: A seta indica o local do sepultamento XXIV, perto de várias feições. Foto: Val Moraes.
Sepultamento (ver figuras 62 e 63) encontrado em 2006 na quadra N1157W1359 1/2N entre $90 \mathrm{~cm}$ e $120 \mathrm{~cm}$ de profundidade, a metade sul foi aberta para a retirada do sepultamento, nesse momento foi encontrado o sepultamento XXV. A

descoberta de um novo sepultamento acarretou em menos tempo para escavar o sepultamento XXIV, por isso optou-se pela retirada em bloco.

\section{2- Descrição}

O sepultamento é individual e primário (conexões lábeis e permanentes estão presentes), o indivíduo está fletido e aparentemente foi enterrado em um espaço restrito $(55 \mathrm{~cm}$ no eixo norte-sul por $40 \mathrm{~cm}$ no eixo leste-oeste). Por

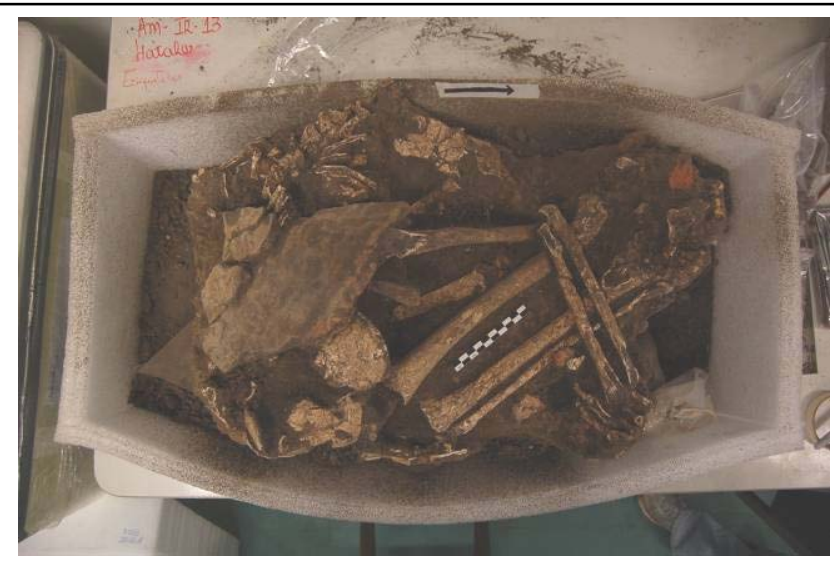

Figura 63: Foto do Sepultamento XXIVem bloco no laboratório. Foto: Val Moraes.

cima do crânio está presente um grande fragmento de cerâmica que se fragmentou em um período antigo com a pressão da terra. Não se sabe se há uma relação direta entre a cerâmica e o sepultamento, provavelmente não, devido ao caráter fragmentário da cerâmica e único do depósito. É possível que sua presença esteja relacionada aos pisos de construção do montículo ou feições (ver figura 62). Junto ao sepultamento, de maneira aleatória, estão presentes vários fragmentos de ossos/casco de fauna. 
Pelo posicionamento dos ossos o indivíduo fora colocado em uma cova pequena, há pouca movimentação dos ossos e o esqueleto como um todo está “agrupado”. O indivíduo estava com as pernas fletidas e com a parte superior do corpo na diagonal (como se tivesse sido empurrado para caber), essa posição é perceptível pela coluna e as costelas (ver na figura 64 que a coluna está diagonal com as costelas esquerdas em face postero-lateral). Isso fez com que o coxal e os membros apareçam em uma posição sentada de lado (pernas para o lado), enquanto que a parte

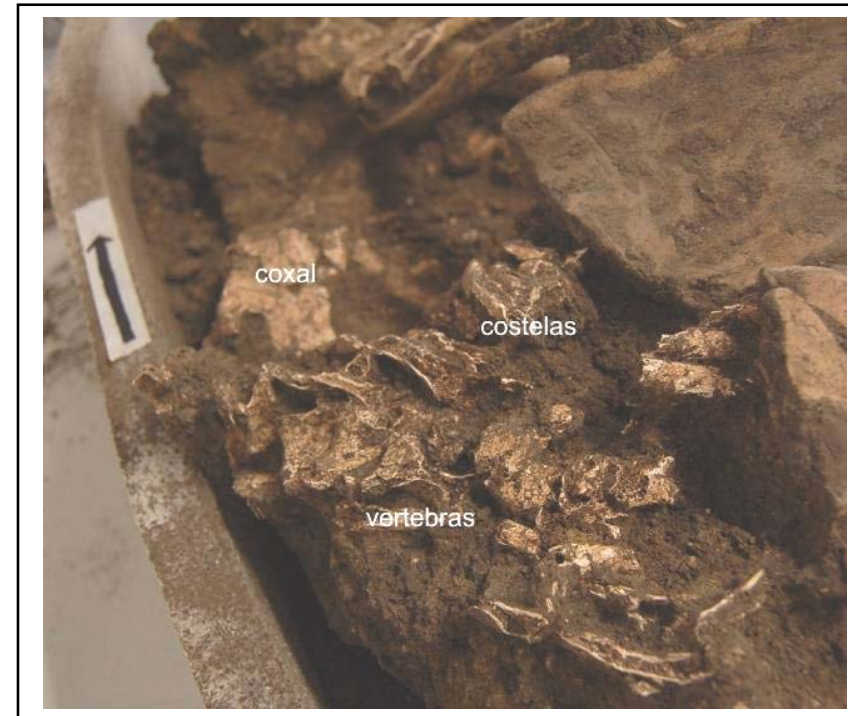

Figura 64: detalhe da coluna vertebral do indivíduo no sepultamento XXIV. Foto: Val Moraes.

superior do esqueleto parece estar deitada. A coluna e as costelas caíram durante a decomposição à direita do indivíduo e o crânio rolou para o interior da área do corpo, pois deveria haver bastante espaço vazio. $\mathrm{O}$ grande fragmento de cerâmica mencionado acima seguiu o crânio.

\section{Próximo a esse} sepultamento havia feições com cerâmica e grande quantidade de material faunístico. Este é mais um caso de associação entre essas duas estruturas. Entre e dentro dessas estruturas havia grandes fragmentos de cerâmica, ainda não foi possível estabelecer se pertencem ao mesmo vaso.

Manchas de sedimento amarelo mais compactas do que o sedimento escuro estavam presentes ao redor e no meio do sepultamento. Possivelmente, quando escavaram a cova inicial, esse sedimento amarelo já estava misturado à terra preta e teria vindo junto com a terra utilizada para a construção do montículo. A escavação desse bloco foi interrompida, mas podemos estimar que o indivíduo é um adulto (todos os ossos retirados estavam ossificados), mas não podemos precisar a idade ou o sexo por enquanto. Os ossos são pequenos quando comparados ao resto da coleção.

\begin{tabular}{|l|l|l|l|}
\hline Indivíduo & Idade & Sexo & Observações \\
\hline A & Adulto & - & \\
\hline
\end{tabular}




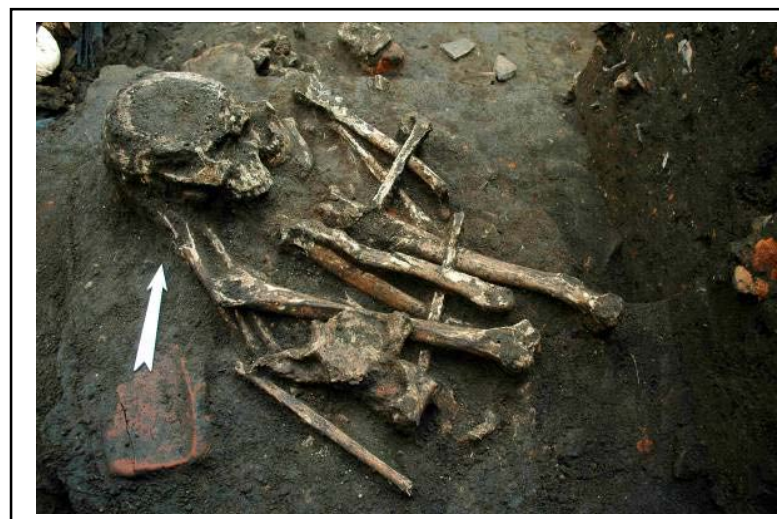

Figura 65: Foto do Sepultamento XXV. Foto: Val Moraes.

\section{1- Localização}

Sepultamento (ver figuras 65 e 66) encontrado na quadra N1157W1359 entre $80 \mathrm{~cm}$ e $90 \mathrm{~cm}$ de profundidade. Entretanto, parte do sepultamento continuava na metade norte da quadra N1156W1359. Este sepultamento foi descoberto quando abrira-se meia quadra para a retirada

do sepultamento XXIV (ver figura 66).

\section{2- Descrição}

Esse sepultamento é primário e individual. Inicialmente descrito em campo como direto e secundário. Mas dúvidas surgiram enquanto se escavava a mandíbula em laboratório. Foram encontradas vértebras cervicais em conexão estrita logo atrás da mandíbula. Os ossos longos, depois de analisados e comparados às fotos e croquis, sugerem um sepultamento primário, mas que sofreu processos tafonômicos intensos. O espaço vazio criado pela decomposição e talvez pela existência de um cesto ou invólucro ao redor do esqueleto, que apesar de não ter sido atestado diretamente aqui, há indícios nos sepultamentos XII e XIII (ver figuras 24 e 25) - associado possivelmente às ações de

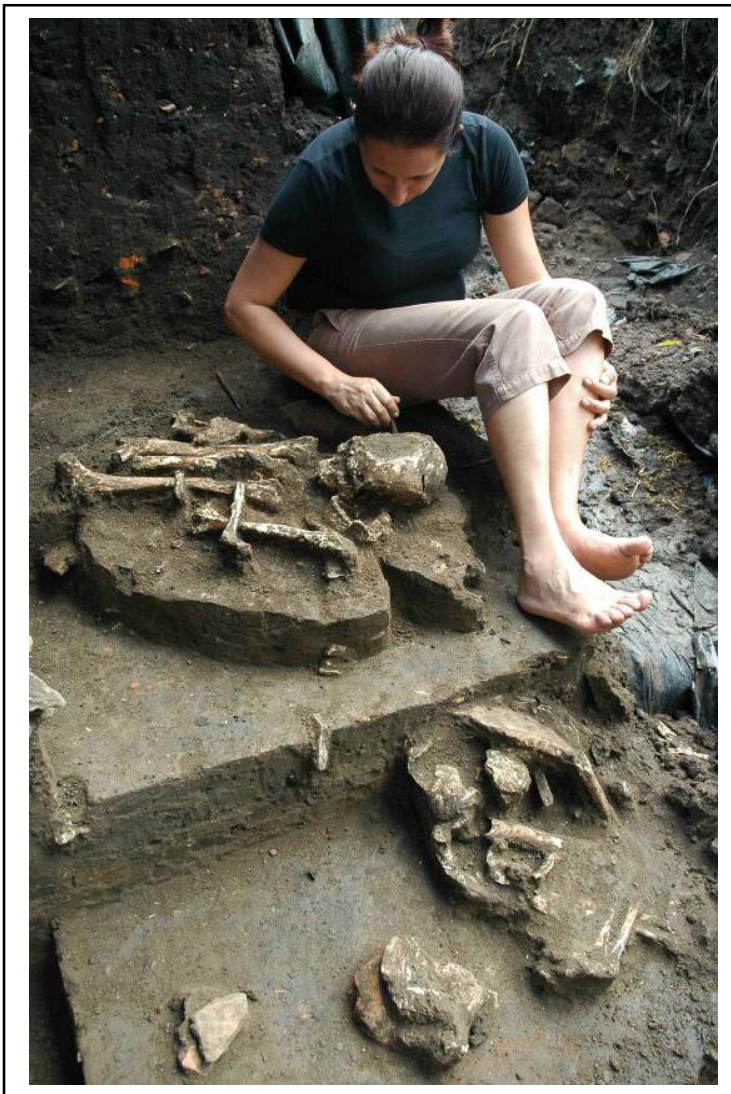

Figura 66: Acima está o sepultamento XXV, enquanto que embaixo está o sepultamento XXIV.

animais (duas diáfises perpendiculares, podendo indicar um rastro de passagem), ou desmoronamentos durante a decomposição, podem ter criado um efeito de desordem a 


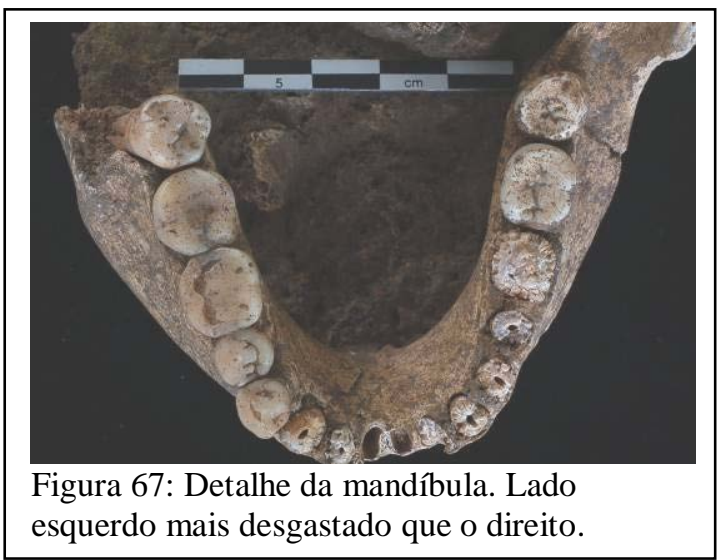

primeira vista. Mas uma vez analisados os ossos, os mesmos estão em posição anatômica, apesar de alguns não mais estarem em conexão.

Além disso, o bloco de vértebras e costelas retirados em campo (PN 22027.20) sugere uma decomposição in situ. Mesmo se estes se encontram em estado de decomposição extremamente avançada podemos perceber a ordem anatômica. O indivíduo foi enterrado em decúbito dorsal com as pernas fletidas sobre o corpo.

O indivíduo em questão era um adulto ou adulto maduro (visto os dentes e o crânio), entretanto, não pudemos estimar o sexo.

A mandíbula, apesar de pequena, é robusta. Os dentes apresentam desgastes desiguais (ver figura 67), que parecem ligados a uma mastigação defeituosa ou utilização dos dentes como instrumentos (Scott e Turner, 1997).

\begin{tabular}{|l|l|l|ll|}
\hline Indivíduo & Idade & Sexo & Observações \\
\hline A & $\begin{array}{l}\text { Adulto } \\
\text { Maduro }\end{array}$ & - & $\begin{array}{l}\text { Desgaste desigual dos } \\
\text { dentes da mandíbula }\end{array}$ \\
\hline
\end{tabular}

\section{SEPULTAMENTO XXVI}

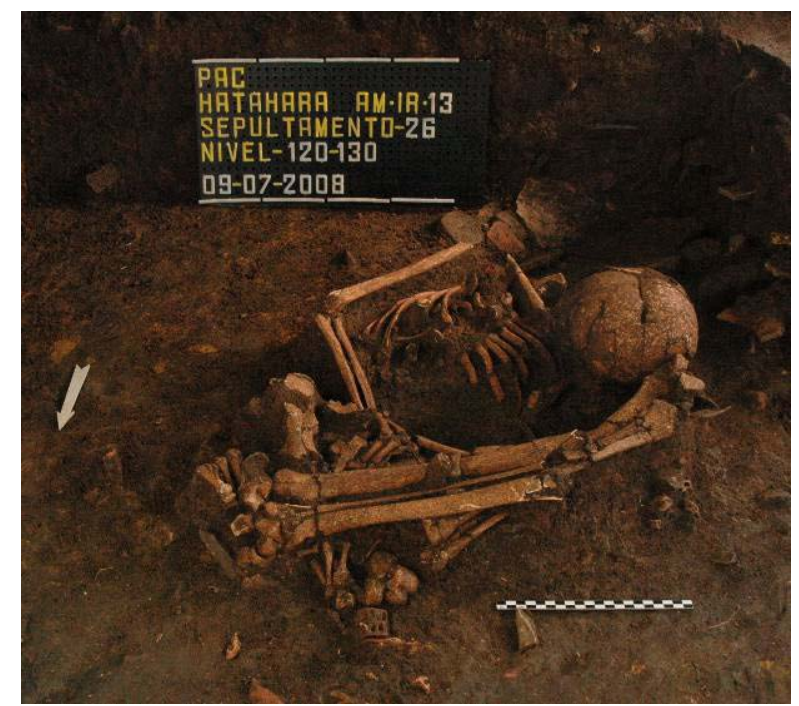

Figura 68: Sepultamento XXVI. Foto: Val Moraes.

\section{1- Localização}

Este sepultamento foi encontrado em 2008 durante a limpeza do perfil sul criado pela escavação das unidades abertas em 2006 (ver figura 68). Ele está localizado entre as quadras N1157W1358 (1/2 S) e N1156W1358 (1/2N), o crânio aparece no meio do nível 110$120 \mathrm{~cm}$ e base da coluna - que 
aparenta ser o ponto mais baixo - está a $135 \mathrm{~cm}$ de profundidade, esse é aproximadamente o limite da camada monticular (IV) e da camada pré-montículo (III).

\section{2- Descrição}

O sepultamento começou a ser escavado e desmontado em campo, mas parte dele teve que ser retirada em bloco. Ambas as pernas do indivíduo estavam fletidas para o lado esquerdo do indivíduo, numa

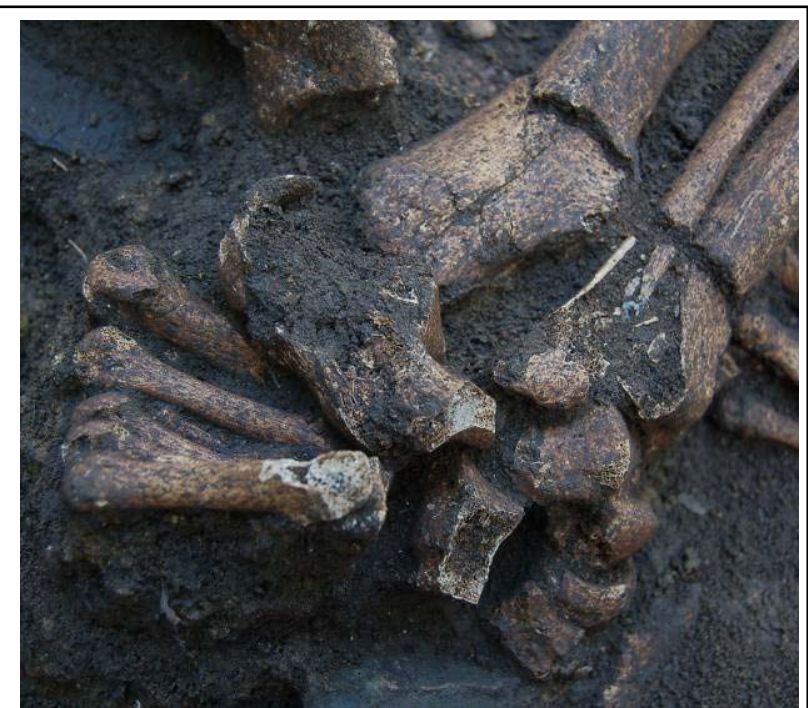

Figura 69: Sepultamento XXVI. Detalhe pé direito. posição parecida com a do sepultamento XIX. Durante o processo de decomposição e/ou devido a pressão da terra o crânio se deslocou um pouco para ficar entre a caixa torácica e o braço esquerdo.

A posição das costelas e vértebras indicam que o corpo foi depositado em decúbito dorso-lateral. Várias quebras (ante-braço e canela) foram devido a pressão,

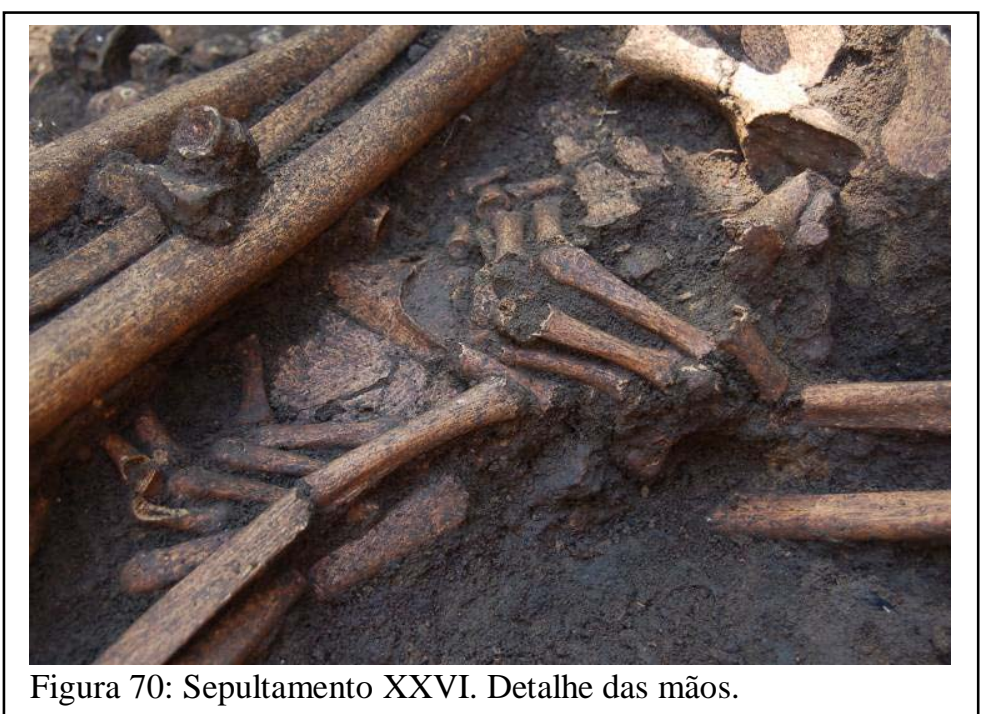
provavelmente recente e talvez da própria escavação.

Efeitos de compressão foram encontrados na mão esquerda e no pé direito (ver figuras 69 e 70). A mão está quase a $180^{\circ} \mathrm{em}$ relação a ulna e rádio esquerdos, e ela estava nessa posição desde o enterramento, pois a decomposição se fez nessa posição (ver figura 70). É provável que isso seja o resultado de força aplicada na hora do enterramento sobre essa parte do esqueleto. Um efeito parecido foi identificado no pé, os metatarsos direitos estão virados para trás e aparecem na face inferior ou latero-inferior (ver figura 69). Não foram identificados marcas de calos ósseos ou articulações disformes que indicassem problemas no pé antes da 
morte do indivíduo - a análise laboratorial ainda está em andamento - o que parece mais simples e provável é que o pé tenha sido forçado para entrar em uma cova pequena. Com o pé esquerdo o efeito é diferente, ele caiu quando começou a se separar da tíbia e fíbula, mas como o espaço era restrito os metacarpos viraram

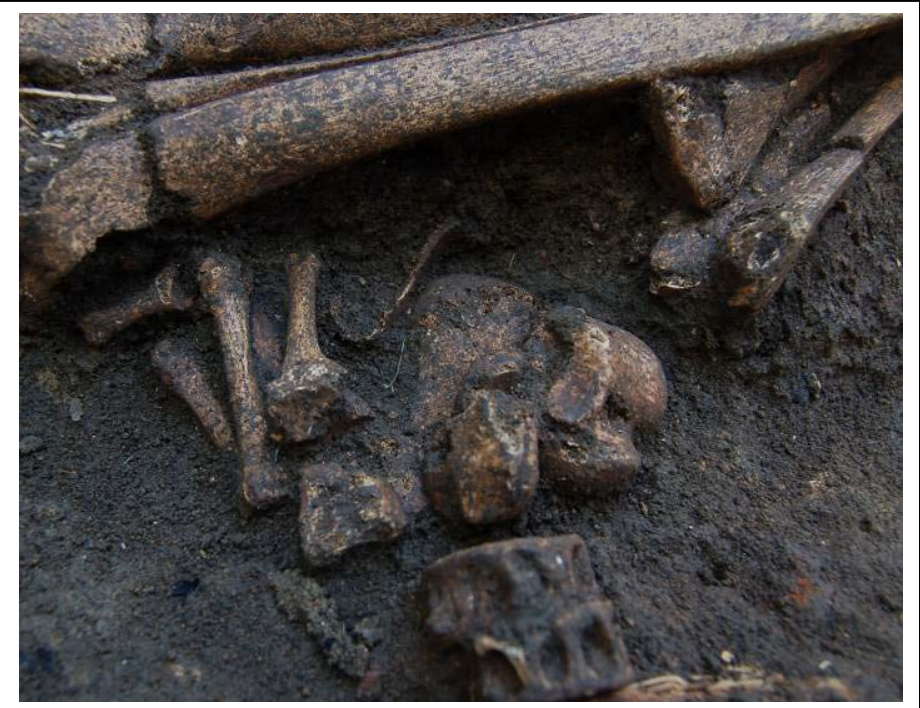

Figura 71: Sepultamento XXVI. Detalhe pé esquerdo. sugerindo um efeito de parede (ver figura 71).

A conservação geral do esqueleto é boa, o preenchimento com terra deve ter sido relativamente rápido, visto a posição instável de alguns ossos (patela, costelas, metacarpos e metatarsos). Próximo ao sepultamento estava associada uma concentração de cerâmicas grandes considerada como uma feição. Perto do pé esquerdo e em cima de alguns ossos encontramos várias vértebras de peixe (ver figura 71), além disso há numerosos fragmentos de cerâmica.

Todos os ossos estão ossificados, portanto o indivíduo é um adulto, mas como a análise ainda está em andamento não conseguiu-se precisar a idade ou estimar o sexo.

\begin{tabular}{|c|c|c|c|}
\hline Indivíduo & Idade & Sexo & Observações \\
\hline A & Adulto & - & $\begin{array}{ll}\text { A maior parte do } \\
\text { sepultamento } \\
\text { em bloco }\end{array}$ \\
\hline
\end{tabular}

\section{SEPULTAMENTO XXVII}

\section{1- Localização}

Como mencionado anteriormente em 2008 abriu-se o montículo III para verificar sua composição, seu contexto e assegurar de que de fato era uma estrutura construída. Até aquele momento o M.I do Hatahara era o único em toda Amazônia Central associado a um contexto funerário. Foi com grande surpresa que constatou-se a presença desse sepultamento no canto de quatro unidades N1308W1298, 
N1309W1298, N1308W1297 e N1309W1297 (ver figura 72), entre $121 \mathrm{~cm}$ e $129 \mathrm{~cm}$ de profundidade (em relação ao DATUM local e não o DATUM do sítio).

\section{2- Descrição}

Esse sepultamento estava abaixo de uma grande concentração de cerâmica que forma a camada monticular do MIII, onde a cerâmica ao redor pertence a fase

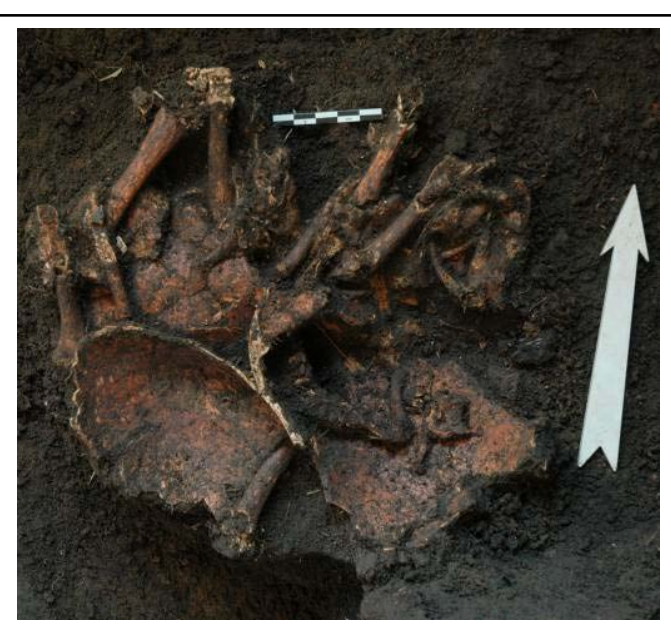

Figura 72: sepultamento XXVII. Ossos longos ao norte e crânio ao sul. Foto: Val Moraes.

Manacapuru. Entretanto, essa associação pode ser artificial, criada por uma cova profunda e a incapacidade de determinar os limites da cova através do sedimento.

Este indivíduo infantil já tinha pelo menos os quatro incisivos superiores mas com as raízes em formação, a maxila está praticamente toda decomposta. As suturas do crânio ainda estavam em processo de ossificação e este abriu por completo. É difícil saber se esta abertura se deu in situ ou se o indivíduo foi levado para o enterramento final já parcial ou totalmente decomposto. Crianças pequenas tem poucos ossos fusionados. Durante a decomposição, se há presença de espaços vazios originais, muitos ossos se movimentam (Duday, comunicação pessoal) e criam um "efeito de bagunça” freqüentemente associado a sepultamentos secundários. Devido a posição dos ossos longos que estão quase todos posicionados ao norte do crânio e por cima de uma parte deste é mais provável que seja um sepultamento secundário.

\begin{tabular}{|l|l|l|l|}
\hline Indivíduo & Idade & Sexo & Observações \\
\hline A & Infantil & - & Parte retirada em bloco \\
\hline
\end{tabular}

\section{SEPULTAMENTO XXVIII}

\section{1- Localização}

Esta concentração óssea (ver figura 73) identificada como sepultamento em 2008 está no montículo IV, entre as quadras N1138W1541 e N1139W1541, a partir de $105 \mathrm{~cm}$ de profundidade (em relação ao DATUM local e não ao DATUM do sítio). Como mencionado anteriormente, Rebellato (2007) identificou este local como sendo 


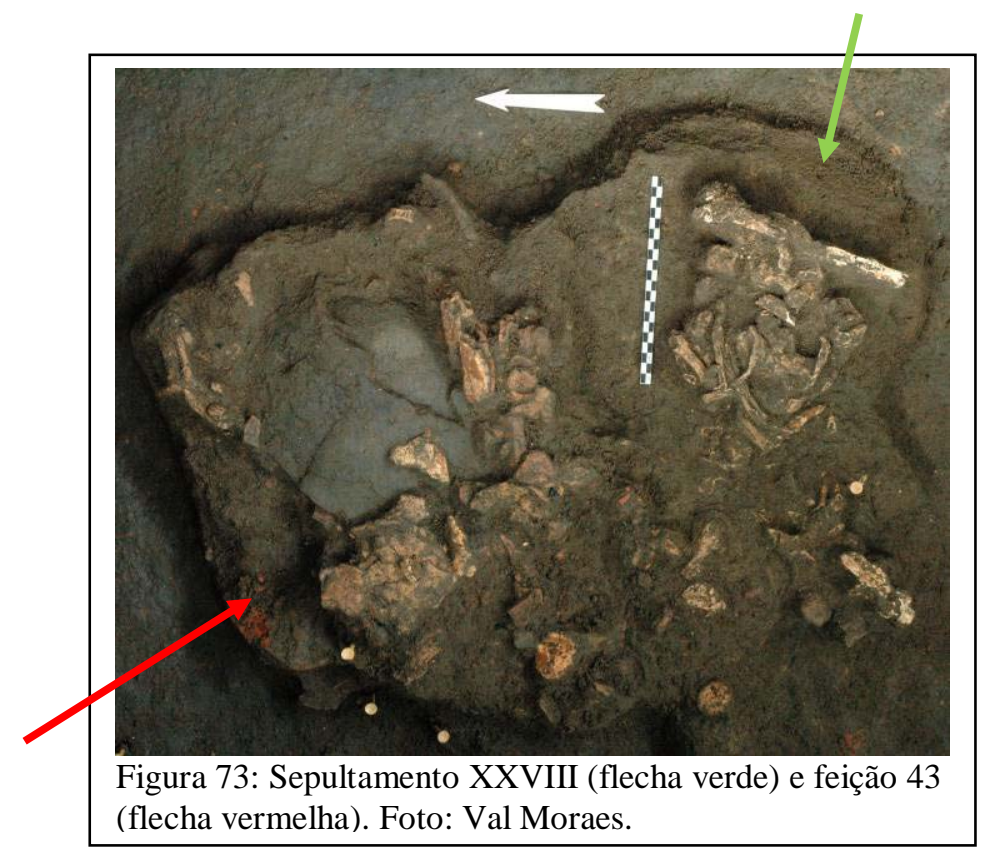

um montículo multifuncional, com uma estrutura diferente dos demais. O nível de perturbação do montículo dificultou muito a leitura do contexto nos primeiros $50 \mathrm{~cm}$.

\section{2- Descrição}

Apesar de ter sido chamado de sepultamento, ainda não se tem certeza absoluta sobre a formação dessa

estrutura. O material estava muito deteriorado em campo para uma avaliação, ele acabou sendo retirado em bloco com consolidantes para estabilizar o material. Perto desse local apareceu um fragmento de mandibula.

É extremamente difícil identificar se havia limites entre a feição 43 e o sepultamento, ou se estavam associados lado a lado como é freqüentemente o caso no montículo I. Parte da dificuldade provém do fato que esse montículo foi o mais intensamente impactado pela agricultura, tanto que a camada monticular não é clara e se apresenta muito fragmentada.

A análise desse sepultamento ainda está em andamento, e não se tem uma contagem do número de indivíduos, sexo ou idade. 


\section{DISCUSSÃO}

Nesse momento os dados apresentados na parte de RESULTADOS serão revistos. Será visto como essas informações se cruzam e algumas observações que deverão ser testadas serão apresentadas.

\subsection{Observações gerais sobre os sepultamentos}

As datações realizadas nos sepultamentos encontrados em 1999 e 2001, assim como os materiais encontrados associados aos sepultamentos e nas camadas arqueológicas, indicam que a maior parte dos sepultamentos estudados pertence à fase Paredão (exceto o sepultamento I). Esses sepultamentos estão distribuídos entre a camada de construção do montículo e logo abaixo dela.

Até o ano de 2005 todos os sepultamentos, exceto o VII, foram identificados por Machado (2005) e Neves et al. (2003) como pertencentes à camada III no montículo I. Entretanto, propõe-se uma alternativa após análise dos perfis e dos dados de profundidade do material (ver MÉTODOS).

Um fator de dificuldade é que alguns sepultamentos estão em zonas de contato entre essas camadas. Mas não há dúvidas quanto à presença de sepultamentos na camada pré-montículo (III) e na camada de construção do montículo (IV). Adicionado a esses dois tempos de enterramento temos o sepultamento I em urna, que parece pertencer a um período mais antigo, pela sua posição estratigráfica e pela data mais antiga obtida diretamente a partir de o osso.

Quanto aos tipos de enterramentos em montículos, o que sobressai é a variedade, pois estão presentes sepultamentos individuais, múltiplos, primários, secundários, diretos e indiretos. Essa diversidade vai ao encontro com o que foi mencionado por Sheila Mendonça de Souza (comunicação em simpósio, Semana de Arqueologia, do MAE/USP em 2007), que propõe que a variabilidade em tipos de sepultamento é tão grande nas terras baixas da América do Sul que diminui o potencial explicativo desse tipo de análise. Entretanto, algumas recorrências que parecem notáveis foram identificadas no sítio Hatahara. 


\begin{tabular}{|l|l|l|l|l|}
\hline Sepultamentos & Indiretos & $\begin{array}{l}\text { Indiretos } \\
\text { prováveis }\end{array}$ & $\begin{array}{l}\text { Diretos } \\
\text { prováveis }\end{array}$ & $\begin{array}{l}\text { Não } \\
\text { identificado }\end{array}$ \\
\hline $\begin{array}{l}\text { Individuais } \\
\text { primários }\end{array}$ & & $\begin{array}{l}\text { VIII, IX/XII, } \\
\text { XII, XXV }\end{array}$ & $\begin{array}{l}\text { IV, XIX, XXIV, } \\
\text { XXVI }\end{array}$ & $\begin{array}{l}\text { VII?, XX, } \\
\text { XXI }\end{array}$ \\
\hline $\begin{array}{l}\text { Individuais } \\
\text { secundários }\end{array}$ & & III? & & $\begin{array}{l}\text { VI?, XVI, } \\
\text { XVII, XXIII, } \\
\text { XXVII, } \\
\text { XXVIII? }\end{array}$ \\
\hline $\begin{array}{l}\text { Múltiplos } \\
\text { secundários }\end{array}$ & I & & XIV & II, V, X? \\
\hline Depósitos & & & $\begin{array}{l}\text { XI, XV, XVIII, } \\
\text { XXII }\end{array}$ & \\
\hline
\end{tabular}

Tabela 3: Sepultamentos por tipo de enterramento, número de indivíduos e relação direta ou indireta. Em negrito são os sepultamentos com indivíduos infantis e os que são seguidos por um ponto de interrogação têm algum problema de identificação.

Os sepultamentos individuais primários estão em decúbito dorsal ou dorsolateral com as pernas fletidas sobre ou ao lado do corpo em um espaço que é geralmente restrito (verticalização das clavículas e escapulas). Esse tipo de enterramento aparece mais freqüentemente associado a indivíduos adultos. Entretanto, a conservação dos indivíduos jovens é sempre pior, as crianças são mais freqüentemente encontradas em sepultamentos secundários. Possíveis exceções parecem ser os sepultamentos VII e X, mas para estes não há como confirmar se eram primários ou secundários.

A presença de espaços vazios importantes dentro de alguns sepultamentos primários foi atestada (por exemplo, sepultamentos VIII e XXV). Estes espaços são visíveis pela movimentação dos ossos. Como mencionado na parte de RESULTADOS a presença de cestas ao redor de alguns sepultamentos é deduzida pela posição dos ossos e pela impressão das fibras em ossos de fauna soltos no sedimento logo abaixo dos indivíduos (ver figuras 24 e 25).

Cestarias têm um tempo de decomposição diferente, mais lento, que as partes moles dos sepultamentos, portanto permitiriam que esses espaços existissem durante um tempo prolongado. Os indivíduos que foram provavelmente colocados em contato direto com o solo foram identificados pelo preenchimento progressivo identificado pela posição assumida pelos componentes de algumas articulações. Por exemplo, ossos como as patelas ou clavículas que geralmente cairiam assim que as partes moles desaparecessem ficaram em posição anatômica. Verticalmente não foram 
identificados locais preferenciais esses sepultamentos aparecem entre $77 \mathrm{~cm}$ e $131 \mathrm{~cm}$ de profundidade, distribuídos entre as camadas III e IV.

Houve uma grande dificuldade em precisar os sepultamentos individuais secundários e, por vezes permaneceram dúvidas sobre o tipo de enterramento, pois alguns estavam demasiadamente perturbados. Esse tipo de sepultamento aparece mais freqüentemente associado a indivíduos adultos jovens ou infantis, sepultamentos III, VI, XVI, XXIII e XXVII - para os outros dois sepultamentos identificados nessa categoria há dúvidas sobre a natureza (XXVIII) ou o grau de perturbação (XVII). Não foi possível determinar se havia algum tipo de invólucro em material perecível ao redor da maior parte dos sepultamentos, entretanto no sepultamento III este é sugerido pelo espaço e posicionamento dos ossos. Como para os sepultamentos individuais primários, esses sepultamentos ocorrem entre as camadas III e IV, entre $82 \mathrm{~cm}$ e $108,5 \mathrm{~cm}$ no montículo I.

Quanto aos sepultamentos múltiplos e secundários foi interessante constatar que todos eram compostos por indivíduos adultos e infantis, em proporções variadas e, que, desconsiderando o jovem indivíduo robusto do sepultamento XXIII, todos os outros indivíduos robustos (com partes corticais dos ossos longos mais espessas e densas que os outros da série) estavam nesses sepultamentos. Não foi possível, no entanto, determinar se todas as mortes ocorreram ao mesmo tempo, pois o tratamento dos corpos em dois tempos permite que indivíduos falecidos em épocas diferentes sejam enterrados juntos. Desconsiderando o sepultamento Manacapuru, que pertence a outra época, percebe-se que esses sepultamentos estão na camada de construção do montículo I (exceto o sepultamento X).

Os depósitos de ossos que não puderam ser confirmados como sepultamentos estão entre $73 \mathrm{~cm}$ e $105 \mathrm{~cm}$ de profundidade, que também corresponde ao local onde as camadas III e IV se encontram. Esses fragmentos de ossos soltos no sedimento atestam a movimentação de solo no sítio que deve ter ocorrido durante a construção dos montículos e os períodos de ocupação. É interessante notar que até o momento não foram identificados sepultamentos múltiplos e primários, nem cremações. 
Segue abaixo uma tabela com a localização espacial dos sepultamentos:

\begin{tabular}{|c|c|c|c|c|}
\hline Sepultamento & Localização & Camada & $\begin{array}{l}\text { Profundidade } \\
\text { do topo }\end{array}$ & $\begin{array}{l}\text { Profundidade da } \\
\text { base }\end{array}$ \\
\hline I & N1152W1359/60 & camada III & Aprox. 98cm & $137 \mathrm{~cm}$ \\
\hline II & N1152W1359/60 & camada IV & $76 \mathrm{~cm}$ & $88 \mathrm{~cm}$ \\
\hline III & N1152W1359/60 & Camada IV & $96 \mathrm{~cm}$ & $107 \mathrm{~cm}$ \\
\hline IV & N1160W1360 & camada III & & $90 \mathrm{~cm}$ \\
\hline $\mathrm{V}$ & N1160W1359 & Camada IV & & $77 \mathrm{~cm}$ \\
\hline VI & N1160W1359/60 & camada III & & $105 \mathrm{~cm}$ \\
\hline VII & N1159W1360 & camada IV & & $77 \mathrm{~cm}$ \\
\hline VIII & N1160W1360/59 & camada III & & $110 \mathrm{~cm}$ \\
\hline IX & N1159W1360 & camada III & & $89 \mathrm{~cm}$ \\
\hline $\mathrm{X}$ & N1159W1359/60 & camada III & & $98 \mathrm{~cm}$ \\
\hline XI & $\begin{array}{l}\text { N1159W1359 e } \\
\text { N1160W1359 }\end{array}$ & camada III & & $105 \mathrm{~cm}$ \\
\hline XII & N1158W1360 & camada III & & $105 \mathrm{~cm}$ \\
\hline XIII & N1153/54W1360 & camada III & & $125 \mathrm{~cm}$ \\
\hline XIV & N1160W1358 & camada IV & $75 \mathrm{~cm}$ & $83,5 \mathrm{~cm}$ \\
\hline $\mathrm{XV}$ & N1159W1357 & camada IV & $85,5 \mathrm{~cm}$ & $98,5 \mathrm{~cm}$ \\
\hline XVI & N1158W1357 & camada IV & Aprox. $85 \mathrm{~cm}$ & Aprox. 95cm \\
\hline XVII & N1160W1359 & camada IV & $82 \mathrm{~cm}$ & $85 \mathrm{~cm}$ \\
\hline XVIII & N1157W1359 & camada III & $73 \mathrm{~cm}$ & $\begin{array}{l}\text { 73cm (lâminas } \\
\text { finas de osso) }\end{array}$ \\
\hline XIX & $\begin{array}{l}\text { N1158W1358 } \\
\text { N1158W1359 }\end{array}$ & camada IV & Aprox. 92,5cm & $115 \mathrm{~cm}$ \\
\hline $\mathrm{XX}$ & $\begin{array}{l}\text { N1158W1357 e } \\
\text { N1158W1356 } \\
\text { SW1/2 }\end{array}$ & camada III & Aprox. 96cm & Aprox. $100 \mathrm{~cm}$ \\
\hline XXI & N1159W1357 & camada III & Aprox. $100 \mathrm{~cm}$ & Aprox. $110 \mathrm{~cm}$ \\
\hline XXII & $\begin{array}{l}\text { N1160W1356 e } \\
\text { N1160W1357 }\end{array}$ & camada III & Aprox. 100cm & Aprox. $105 \mathrm{~cm}$ \\
\hline XXIII & N1160W1359 & camada III & Aprox. 99cm & Aprox. $108.5 \mathrm{~cm}$ \\
\hline XXIV & N1157W1359 & Camada IV & Aprox.90cm & Aprox $120 \mathrm{~cm}$ \\
\hline XXV & N1157W1359 & Camada IV & Aprox. $80 \mathrm{~cm}$ & Aprox. 90cm \\
\hline
\end{tabular}




\begin{tabular}{|l|l|l|l|l|}
\hline XXVI & $\begin{array}{l}\text { N1157W1358 (1/2 } \\
\text { sul) e } \\
\text { N1156W1358 (1/2 } \\
\text { norte) }\end{array}$ & Camada III & Aprox. 119cm & $131 \mathrm{~cm}$ \\
\hline XXVII & $\begin{array}{l}\text { N1308W1298 (1/4 } \\
\text { NE), N1309W1298 } \\
(1 / 4 \text { SE) } \\
\text { N1308W1297 (1/4 } \\
\text { NW) e } \\
\text { N1309W1297 (1/4 } \\
\text { SW) }\end{array}$ & Camada III & $120 \mathrm{~cm}$ & $129 \mathrm{~cm}$ \\
\hline XXVIII & $\begin{array}{l}\text { N1139W1541 e } \\
\text { N1138W1541 }\end{array}$ & Camada III & $105 \mathrm{~cm}$ & $\begin{array}{l}130 \mathrm{~cm} \text { (pedestal } \\
\text { do bloco) }\end{array}$ \\
\hline
\end{tabular}

Tabela 4: Sepultamentos e depósitos relacionados a suas camadas e profundidades respectivas.

O padrão funerário da fase Paredão no sítio Hatahara difere do que é conhecido para a época em outros sítios arqueológicos. Hilbert (1968) descreve, em seu trabalho pioneiro para a região, que essa fase era conhecida pelas suas grandes urnas funerárias. Nos relatórios de levantamento e resgate arqueológico no município de Manaus para sítios dessa época também encontram-se menção de concentrações de grandes recipientes (muitas vezes com ossos dentro) (Costa e Lima, 2006; Hilbert, 1968; Neves e Costa, 2001).

Essa variedade de padrões funerários em sítios que aparentemente pertencem à mesma fase pode ter diferentes explicações: 1- Considerando-se que a fase teve a duração de quase seis séculos e não há datações diretas para as urnas funerarias, é possível o uso intermitente do local por um longo período em que podem ter ocorridos mudanças no padrão funerário; 2- Considerando-se a generalidade de suas definições, as fases são utilizadas como instrumentos que não correspondem necessariamente a um único grupo, e variações nos padrões funerários entre aldeias e grupos são descritas na etnografia 3- A quase totalidade de dados sobre os padrões funerários da fase Paredão provém do município de Manaus na margem esquerda do rio Negro, sendo obrigatório considerar a hipótese de variações regionais; 4- O local para enterros em urnas durante a Fase Paredão, dentro do sítio Hatahara, pode não ter sido ainda encontrado. 
A terceira hipótese é reforçada pelo fato de que em 2009 no sítio Laguinho, também no município de Iranduba, parte de um sepultamento foi encontrado dentro de uma feição Paredão, mas fora de montículo.

Embora no sítio Hatahara haja uma grande concentração de urnas funerárias, elas pertencem a um momento mais antigo de ocupação, associado à fase Manacapuru, época que também é conhecida por um padrão funerário relacionado a enterramentos em urnas funerárias (Hilbert, 1968). Deve-se mencionar que em 2007 um sepultamento individual e secundário provavelmente da fase Manacapuru, foi encontrado fora de urna no sítio Grêmio, município de Manacapuru, demonstrando que durante esse período também ocorria certa variedade de comportamentos.

Enquanto que as análises de morfologia e estilo, sobre material cerâmico indicam certa continuidade de traços entre as três fases mais antigas (Açutuba, Manacapuru e Paredão) associadas à tradição Borda Incisa, definida inicialmente por Meggers e Evans em 1961 (ver Lima, 2008 e Moraes, 2006 para uma discussão mais aprofundada) os padrões funerários encontrados no sítio Hatahara parecem indicar uma ruptura. Além desses elementos outros, como padrões de assentamento, manufatura e escala de produção das cerâmicas (Moraes, 2006; Rebellato, 2007) também já haviam sido sinalizados como características de diferenciação entre as fases.

\subsection{Observações gerais sobre os processos tafonômicos}

Desde o começo do trabalho o objetivo foi compreender os processos tafonômicos agindo sobre os sepultamentos, correspondendo ao que foi apresentado em FUNDAMENTAÇÃo TEÓRICA. Mas a compreensão dos processos tafonômicos passa pela compreensão do local onde eles estavam inseridos. As áreas de terra firme da Amazônia Central são conhecidas pelos seus solos ácidos onde as frações orgânicas existem em níveis reduzidos, menos de 3\%, mesmo em áreas de floresta primária (Teixeira et al., 2009).

Na maior parte da Amazônia Central em especial nas áreas de terra firme onde atua o PAC, predominam Latossolos Amarelos distróficos de textura argilosa e muito argilosa e Argissolos Amarelos distróficos de textura média argilosa. Há também em 
menor percentual solos com presença de horizontes plínticos (Plintossolos) e de textura arenosa (Espodossolos). A grande maioria dos sítios conhecidos até o momento se encontra predominatemente em Argissolos (Caldeirão, Açutuba) e Latossolos (Hatahara, Costa do Laranjal) com alguns “perfis arqueológicos” em solos com horizontes petroplínticos (Plintossolos e Argissolos) na área do Lago do Limão (Moraes, 2006; Macedo et al., 2007) e de alguns sítios arqueológicos em Espodossolos, como aqueles estudados por Costa (2009). Todos estes ambientes edáficos são ácidos e pobres em bases trocáveis (especialmente cálcio, magnésio, potássio) resultado de uma combinação da baixa concentração desses elementos minerais no material de origem (predominantemente de sedimentos arenosos arcoseanos da Formação Altér do Chão) e de um intenso processo de lixiviação decorrente das elevadas temperaturas médias (cerca de $26^{\circ} \mathrm{C}$ sem grande amplitude ao longo do dia ou do ano) e elevada intensidade pluviométrica da região, precipitações médias anuais acima de 2000 mm (Costa et al., 2009). Neste ambiente, encontrar material ósseo conservado é raríssimo.

Os processos tafonômicos identificados que afetaram e conservaram os sepultamentos são vários e, como mencionado anteriormente, esses processos estão ligados preferencialmente ao micro-ambiente local, não às grandes zonas ecológicas (White e Hannus, 1983). Portanto, a compreensão da conservação dos sepultamentos no sítio Hatahara passa por um conhecimento desses fatores locais e como eles interagem entre si.

Em relação aos fatores tafonômicos internos, encontrou-se uma variante a ser considerada, o corpo. No geral, os indivíduos robustos tiveram uma melhor conservação do que os indivíduos jovens, pois os ossos mais densos resistiram melhor aos processos físicos de natureza mecânica (raízes, fauna do solo) e a alguns processos químicos (solução do solo).

A conservação do material ósseo foi bem variada, mas com tendência aos números mais altos do sistema de cotação de Behrensmeyer (1978), portanto de conservação média a péssima. Os ossos haviam sido afetados por processos de intensidades diferentes, mostrando-se fragmentados, erodidos, rachados e craquelados. Muitos, além disso, estavam friáveis, quer dizer que a camada superficial da parte cortical dos ossos estava exfoliando com a escavação e limpeza. Exceto algumas falanges e ossos do metatarso e metacarpo, os ossos longos estavam 
incompletos, com uma ou ambas as epífises deterioradas. Além disso, as diáfises estavam raramente íntegras, a fragmentação muitas vezes impedindo a reconstrução e a utilização de métodos osteométricos. Algumas amostras enviadas para datação não puderam ser aproveitadas, pois, de acordo com o laboratório Beta Analytics, já não havia mais matéria orgânica em quantidade suficiente e a degradação do osso estava muito avançada. O estado desses ossos significa que eles estavam em processo avançado de intemperização (weathering) e que provavelmente não virariam fósseis.

Quanto aos aspectos tafonômicos externos percebeu-se que a principal fonte de preservação e de deterioração sobre os ossos foi o próprio solo - mais especificamente o horizonte antrópico, denominados localmente de "terra preta do índio”.

Em projetos paralelos em andamento, análises químicas e físicas deverão ser realizadas para confirmar o grau e o tipo de impacto nos solos que estão próximos aos sepultamentos preservados. Alguns aspectos serão detalhados a seguir.

A terra preta de índio é conhecida mundialmente pela suas características físico-químicas diferenciais quando comparadas aos solos adjacentes, muitos trabalhos de pesquisa vem sendo realizados para compreender a sua formação e suas características (Glaser e Woods, 2004; Lehmann, et al, 2003; Teixeira, 2009, Teixeira et al, 2009, Woods, 2009). Nestes locais a deposição antrópica de elementos (adição de dejetos e aditivos orgânicos) foi superior aos processos de perda pela volatilização, lixiviação e erosão, típicos da região e portanto alteraram profundamente o solo (Woods, 2009; Woods e Denevan, 2006). Não foi feito aqui um trabalho sobre a terra preta, entretanto alguns elementos desta parecem ter colaborado com a conservação do material orgânico e serão rapidamente abordados aqui (baseado em Denevan, 2009; Limbrey, 1975 apud Woods, 2009; Petersen et al, 2001; Rebellato, 2007; Teixeira et al, 2009; Woods, 2009; Teixeira comunicação pessoal):

- Presença em alta quantidade de carbono de origem pirôgenica. Este ajuda a estabilizar e aumentar o conteúdo de matéria orgânica, podendo reduzir a lixiviação de cátions pelo aumento da capacidade de troca catiônica do solo, aumentar e manter a umidade do solo, aumentar a expressão de propriedades plásticas do solo quando úmido, reduzindo efeitos mecânicos de esmagamento por pisoteio e podendo repelir e reduzir a atividade biológica quando relativamente recentes e com efeitos de substâncias biocidas como o alcatrão e 
o componentes do extrato pirolenhoso. Entretanto pode aumentar a atividade microbiológica quando passível de ser fonte de carbono para microorganismos.

- Presença de carvão pirogênico e cinzas. As cinzas vegetais são extremamente alcalinas ( $\mathrm{pH}$ de 8 a 12), aumentam o $\mathrm{pH}$ do solo mesmo em pequenas concentrações e podem impedir o estabelecimento de condições ácidas decorrentes da decomposição de resíduos orgânicos. O pH das cinzas pode dificultar a sobrevivência de alguns organismos (fungos, bactérias) pela excessiva alcalinidade. Áreas com elevada concentração de carvão vegetal poderão aumentar a sua umidade em baixas tensões, principalmente quando a massa do solo for constituída de minerais predominantemente na fração areia.

- A ação do fogo diretamente sobre o solo, favorecendo agregação de partículas de areia, argila e carvão.

- Grande quantidade de dejetos produzidos por assentamentos longos e numerosos contribuem para o aumento dos níveis nas concentrações de alguns elementos químicos (P, Ca, Cu, Zn, Mn).

- A alta densidade de vestígios arqueológicos, como as cerâmicas, pode aumentar a umidade em substratos arenosos (Macedo et al., 2007) e mesmo reduzir em substratos muito argilosos. As cerâmicas contem elevadas concentrações de nutrientes e podem funcionar como fonte de nutrientes para o solo (Costa et al., 2009). Além disso, a grande quantidade desse material pode proteger os ossos dos processos mecânicos.

- Os maiores teores e principalmente os maiores estoques de matéria orgânica nas TPI são devidos principalmente à reduzida mineralização de carbono de origem pirogênica, não havendo consenso sobre a meia-vida do carvão vegetal nos estudos. Provavelmente a combinação de fatores como a grande quantidade de carvão vegetal, cinzas e outras adições foram os responsáveis pela modificação dos horizontes do solo que levaram a criação das TPI.

Associado a esses elementos típicos das terras pretas em geral, tem-se alguns específicos do sítio Hatahara. Rebellato (2007) através de diversas análises químicas do solo verificou a existência de áreas de atividades dentro do sítio, pelas concentrações - de elementos químicos, de matéria orgânica, de expressão da cor e 
espessura do horizonte preto , quantidade de cerâmica - diferenciadas (p. 60-61). As áreas de montículo apresentaram elevadas concentrações dos elementos P e Ca aos $50 \mathrm{~cm}$ e $90 \mathrm{~cm}$ de profundidade, que, de acordo com Rebellato (2007), podem estar parcialmente relacionados à presença de sepultamentos. Em Costa et al. (2009) sepultamentos humanos também são apresentados como possíveis responsáveis por parte das alterações químicas do solo. Pelo o que foi percebido no atual trabalho, concorda-se que parte do alto teor de cálcio possa ser oriundo dos sepultamentos. Entretanto, a maior parte dos sepultamentos está em torno de um metro de profundidade ou mais e, não há sepultamentos aos $50 \mathrm{~cm}$ de profundidade. Outras sugestões são que esse teor mais elevado perto da superfície poderia ser explicado pelo acúmulo de terra, com vestígios ósseos, vindos durante a construção do montículo, ou que o cálcio tenha outra origem. O pH da terra preta medido no sítio está próximo da neutralidade $(6,5)$.

Outra característica confirmada por Rebellato (2007) é a textura do solo, que é argilosa na sua grande maioria, principalmente a partir dos $50 \mathrm{~cm}$ de profundidade.

A presença do sedimento com predominância da fração argila parece ter tido uma influência direta sobre a conservação dos sepultamentos. O fato das TPI com predomínio da fração argila apresentarem uma grande porosidade total composta principalmente por poros de pequenos diâmetros (microporos), num ambiente de elevada precipitação, que ficaria saturado de água por um grande período do ano, terminaria com o oxigênio se dissolvendo na água e se esgotando, criando assim um ambiente anaeróbico, limitando a atividade de todos os animais e bactérias aeróbicas (Wenceslau Teixeira comunicação pessoal). A relativa profundidade dos sepultamentos provavelmente também dificulta existência de poros de aeração com continuidade deles até a superfície para permitir uma aeração destes ambientes. A plasticidade do material argiloso e uma possível compactação no momento do sepultamento pela simples manipulação do material argiloso poderia também contribuir para a redução da aeração destes ambientes. A possibilidade da argila agir como elemento de preservação dos ossos foi inferida no artigo de Marinho et al. "Paleogenetic and taphonomic analysis of human bones from Moa, Beirada, and Zé Espinho Sambaquis, Rio de Janeiro, Brazil” (2006). Adicionalmente os sedimentos argilosos com elevados teores de matéria orgânica apresentam uma elevada coesão 
quando secos (Neves Junior, 2008) e isto criaria uma barreira aos impactos em subsuperfície causado pelas ações mecânicas em superfície.

A quantidade de terra preta no sítio Hatahara certamente está relacionada às concentrações de vários elementos mencionados acima. Como vimos na apresentação do sítio, as áreas de montículo apresentam até $2 \mathrm{~m}$ de acúmulo de terra preta, sendo que certa parte desse acúmulo foi criado artificialmente pela construção do mesmo, mas isso permitiu que áreas espessas - verticalmente - sofressem as alterações de pH e nas estruturas químicas mencionadas. Além disso, a construção dos montículos aumentou a distância entre os sepultamentos e as ações humanas na superfície. Visto o caráter muito argiloso do sedimento (e muito coeso) que formou o montículo podese pensar que essa estrutura acabou servindo de cápsula afastando o impacto das variações climáticas (temperatura e umidade). Portanto, os próprios montículos também são responsáveis pela conservação do material ósseo.

As características do solo parecem ter influenciado na ação de outros fatores aceleradores da decomposição. Assim, os ácidos (ex. ácidos húmicos, ácido carbônico) originários da decomposição dos vegetais podem ter sido neutralizados em sua grande parte, entretanto, as presenças são atestadas nos ossos, onde se pode ver as marcas das raízes.

Vista a compactação do solo e a profundidade dos sepultamentos (aproximadamente 1m), a ação mecânica das plantas também foi reduzida principalmente nos anos recentes pelo uso com plantas com raízes superficiais (bananeiras, mamoeiros). Em casos de abandono como há uma elevada fertilidade e os solos têm relativa elevada capacidade de retenção de águas, as plantas não teriam tendência de aprofundar o sistema radicular, que permanecendo superficial não causaria dano aos sepultamentos. Isso pode ser verificado nos perfis estratigráficos, que não mostram sinais de re-deposição mecânica nas camadas (Neves e Petersen, 2006) (ver anexos 2 e 3).

O solo associado à grande quantidade de cerâmica criou um ambiente mais estável, havendo menos alterações do meio, temperatura e umidade - responsáveis em parte pela aceleração das atividades dos micro-organismos que de acordo com Behrensmeyer (1978) estão relacionados aos processos de “weathering”. Nos níveis de construção dos montículos Machado (2005) fala de “pisos” de construção, que são 
acúmulos de cerâmicas utilizados para levantar essas estruturas. Nesses níveis há mais cerâmica do que terra e, isso pode influenciar a penetração e evaporação da água.

Não foram encontradas marcas de tratamentos pré-sepulcrais (como corte ou queima) sobre os ossos. Nenhum dos ossos analisados apresentou marcas (patologias ou ferimentos de defesa) que pudessem sugerir as causas das mortes. Mas o fato de existirem os sepultamentos múltiplos levanta algumas perguntas relacionadas ao motivo das mortes dos indivíduos. Em caso de mortes espaçadas no tempo, onde ficariam "guardados" os ossos antes do enterramento definitivo? Todos os indivíduos eram da mesma família? Se todas as mortes foram próximas no tempo, qual fator poderia explicar a situação, doença, guerras ou sacrifícios? Vista a composição da maior parte dos sepultamentos múltiplos (adultos e crianças), é possível imaginar que pertençam a uma única família. Análises de DNA poderiam fornecer pistas sobre essas associações.

Através do estudo dos sepultamentos foram identificadas evidências de perturbação humana neles e nos montículos como um todo. Negativos de buraco de poste (sepultamento XIX) estão presentes, assim como o desaparecimento de partes importantes dos corpos que não são explicados por uma deterioração diferencial (sepultamento XIII, XX e XXI). Além disso, os vários ossos soltos no sedimento, que inicialmente foram identificados como sepultamento, mas que agora são chamados de depósitos, demonstram o impacto das atividades sobre os sepultamentos. O fato de haver sepultamentos abaixo e dentro do montículo pode explicar porque alguns sepultamentos foram tão perturbados. Estes podem ter sofrido durante a construção do montículo, com a retirada e depósito de terra de áreas que já tinham sepultamentos. Outro elemento que mostra a movimentação de solo ocorrida são as manchas de argila de cor amarelada, típica dos horizonte subsuperficiais do solos da região (Latossolos e Argissolos), mas misturadas às camadas mais escuras terra preta.

A permanência das áreas escavadas abertas teve grande impacto sobre os sepultamentos. Por exemplo é visível a diferença de conservação no sepultamento IX, que foi cortado em 2001 (ver RESULTADOS). As áreas abertas colocaram os sepultamentos e todos os materiais orgânicos que estavam próximos em contato com as variações de temperatura que causou craquelamento e esfarelamento dos ossos. Visto o caráter argiloso do sedimento, não há muitos desmoronamentos, por isso inicialmente se teve uma falsa impressão de conservação. Desde 2008 alguns 
experimentos estão sendo realizados com a conservadora Sílvia Cunha Lima para fechar as áreas de escavação reduzindo o impacto no material orgânico.

\subsection{Discutindo a hipótese inicial}

Na INTRODUÇÃO apresentou-se a hipótese de que os sepultamentos encontrados nos montículos pertenceriam à fase Paredão e que estes seriam responsáveis pela conservação do material ósseo. Além disso, conjecturou-se sobre a possibilidade dos montículos serem "híbridos”, compostos por elementos de habitação e cemitério.

No decorrer desse trabalho foram relatados os resultados e dados obtidos através da aplicação dos métodos relacionados à arqueologia da morte que vieram complementar uma discussão iniciada por outros pesquisadores, como Machado (2005), Neves e Petersen (2006) e Rebellato (2007) a respeito dessas estruturas.

A descoberta de sepultamentos em mais de um montículo no sítio Hatahara em 2008 reforçou a hipótese dos sepultamentos estarem associados a essas estruturas. Ao mesmo tempo uma análise mais detalhada do material ósseo encontrado indicou uma relação complexa entre a construção dos montículos e os sepultamentos préexistentes. Mostrando que sepultamentos também já existiam antes da construção do montículo.

A análise detalhada dos sepultamentos e de seus contextos (posição estratigráfica, análises químicas, material associado, feições associadas e datações) indica que os sepultamentos e os montículos pertencem à fase Paredão (exceto o sepultamento I) (Neves et al., 2007; Rapp Py-Daniel, 2008; Rebellato, 2007; Tamanaha, 2006). Rebellato (2007) propõe duas interpretações possíveis para os montículos, que ela também considera como pertencentes à fase Paredão: 1) teriam sido construídos para abrigar estruturas funerárias, e teriam uma seqüência curta de duração ou 2) seriam o resultado tanto de construção de estruturas funerárias como de estruturas domésticas, estas últimas associadas a períodos de media a longa duração. As estruturas domésticas foram atestadas pela presença de: buracos de poste, fogueiras, silos, remeximentos de terra, presença de vasilhas domesticas - as formas predominantes (Machado, 2005) entre a superfície e $150 \mathrm{~cm}$ de profundidade são os 
assadores, as cuias com pedestal, os vasos com restrição entre corpo e borda, as cestas com alças e pratos rasos com inflexão.

Vestígios da fase Paredão existem antes da construção dos montículos fragmentos cerâmicos dessa fase foram utilizados para a elevação destes - portanto haveria uma mudança de comportamento durante a fase, mas não é possível identificar a causa. Entretanto existe continuação na ocupação e utilização do espaço para enterrar. A presença de feições da fase Paredão é atestada em vários sítios. No próprio sítio Hatahara elas estão presentes em áreas dentro e fora de montículos, por isso inicialmente elas não foram associadas aos sepultamentos. Com o decorrer das escavações dos montículos percebeu-se uma relação entre feições, compostas por vestígios faunísticos e cerâmicas, e sepultamentos. Há necessidade de se realizar um estudo mais fino sobre essas feições para saber se há diferença de composição e de data entre estas e outras feições fora da área monticular. 


\section{CONCLUSÕES:}

- Os sepultamentos no sítio Hatahara e, em qualquer sítio com sepultamentos, têm que ser analisados como parte integrante do sítio para que se possa entender o contexto, pois os indivíduos ali enterrados são partes integrantes do sítio arqueológico podem indicar suas especificidades.

- Até o presente momento, a quase totalidade dos montículos Paredão conhecidos parecem estar relacionados a locais de habitação dentro de aldeias circulares, ou de estruturas circulares em aldeias com formato complexo (Moraes, 2006). A presença de sepultamentos nos montículos do sítio Hatahara poderia ser interpretada como uma característica específica àquele local ou por uma conservação diferencial proporcionada pelos próprios montículos. É possível que a resposta seja uma combinação dessas duas possibilidades. Pois o sítio Hatahara pelo seu tamanho e composição (ex. quantidade de terra preta e cerâmica) tem uma densidade de vestígios maior que a maior parte dos sítios da fase Paredão, mas não de todos. O sítio Laguinho (Castro, 2009) que apresenta uma estrutura mais parecida com o Hatahara também contem vestígios humanos (dente encontrado na peneira e parte de um sepultamento em uma feição), sugerindo que esses sítios grandes são similares nas condições e nos contextos.

- Sepultamentos da fase Paredão seguem um padrão de enterramento diferente dos descritos por Hilbert (1968) para essa fase em outros sítios. Não foram encontradas urnas funerárias Paredão no sítio Hatahara, mas dentre o material diagnóstico analisado existe a presença de apêndices em forma de cabecinhas, típicos indicadores de urnas da fase Paredão. Portanto, é possível que exista dentro do sítio um local com a presença dessas urnas, mas que ainda não foi localizado ou que outros vasos também recebam esses apliques decorativos. É interessante notar que alguns sepultamentos foram encontrados associados a essas cabecinhas, podendo indicar algum valor simbólico a elas.

- Diferentes gestos funerários foram identificados. Os tipos de tratamento dos corpos e dos sepultamentos são diferentes. A idade e, possivelmente o sexo, parece ser um fator de diferenciação, provavelmente de status. Em Machado (2005) já se encontra uma discussão desenvolvida sobre os possíveis 
construtores dos montículos: a autora sugere certa estratificação social aproximando a sociedade construtora a cacicados. Foram identificados sepultamentos individuais primários, individuais secundários e múltiplos secundários, dentre eles alguns deveriam estar em cestarias. Os dados funerários disponíveis até o momento não são, no entanto, conclusivos sobre essa questão.

- Os dados das escavações de 2006 e 2008, quando comparados com os dados obtidos para a fase Paredão como um todo, levam a crer que os montículos tinham uma dupla função de habitação/cemitério, pois há a presença de elementos funerários e de habitação (fogueiras, buracos de poste, cerâmica).

- Na área do montículo I foram identificados pelo menos três grandes momentos de enterramento, sendo dois Paredão e um Manacapuru. Os enterramentos Paredão ocorreram antes e depois da construção do montículo. A mudança na estrutura habitacional não mudou o padrão funerário da fase Paredão no sítio.

- Considerando comente o padrão de enterramento percebe-se uma descontinuidade entre as fases Paredão e Manacapuru, que, de acordo com a literatura, e o que foi encontrado no próprio sítio Hatahara, tem como padrão sepultamentos secundários em urna.

- A associação entre alguns sepultamentos e algumas feições está cada vez mais clara, entretanto ainda não se sabe o significado dessa relação. A presença ou ausência dessas estruturas pode estar relacionada a fatores cronológicos ou rituais.

- A conservação do material orgânico é resultado de vários fatores físicos e químicos, sendo que a maior parte está ligados as características do solo, no caso Terra Preta de Índio. Propõe-se aqui a continuação de análises químicas do sedimento e dos ossos para uma melhor compreensão da interação entre esses componentes. Condições similares ao que existe no sítio Hatahara estão presentes em outros sítios da Amazônia, portanto pode-se esperar que mais sepultamentos em sítios a céu aberto sejam encontrados.

- Entre os montículos, localizados na parte mais densa do sítio, há fortes chances haver um contexto propício para a conservação do material orgânico. Visto que há sepultamentos antes da construção dos montículos, acredita-se que essa área tenha um forte potencial para presença de enterramentos. 
- As características da Terra Preta que devem ter viabilizado a preservação do material ósseo são: o pH neutro, as altas concentrações de cálcio e fosfato, a fração argila, a alta coesão do solo.

- Sumarizando os dados, o sítio Hatahara tem de fato condições excepcionais de preserrvação, surpreendentes quando se considera sua localização e contexto de um sítio a céu aberto localizado próximo à linha do Equador. É provável, no entanto, que à medida que as pesquisas arqueológicas avancem na região, outros sítios com condições de preservação semelhantes sejam localizados, o que possibilitará uma avanço no entendimento dos modos de vida das populações que ocuparam a região no passado pré-colonial, a partir de perspectivas da arqueologia da morte. 


\section{BIBLIOGRAFIA}

Abrahams, P. H, R. T. Hutchings e S. C. Marks Jr., 1998 Atlas en Couleurs d'Anatomie Humaine McMinn, Médecine - Sciences Flammarion, Paris.

Andrews, P., 1995 Experiments in Taphonomy in Journal of Archaeological Science, 22, 147-153.

\section{Arroyo-Kalin, M.,}

2008 Steps towards an Ecology of Landscape: a Geoarchaeological Approach to the Study of Anthropogenic Dark Earths in the Central Amazon region, Brazil. Tese de doutorado. Universidade de Cambridge, Giston College. Cambridge.

Bass, W. M.,

1995 Human Osteology: A Laboratory and Field Manual ( $3^{\text {rd }}$ Edition). Columbia, Missouri: Missouri Archaeological Society.

Behrensmeyer, A. K., 1978 Taphonomic and Ecologic Information from Bone Weathering in Paleobiology, Vol. 4, No. 2. (Spring, 1978), 150-162.

Binford, L.,

1981 Bones: Ancient Men and Modern Myths. Academic Press, New York.

Birkner, R.,

1980 L’image radiologique typique du squelette. Ed. Maloine, Paris.

\section{Bonnichsen, R.,}

1989a Introduction to Taphonomy with an Archaeological Focus in Bone Modification ed. Robson Bonnichsen e Marcella H. Sorg, Center for the study of first Americans, Peopling of the Americas Publications Edited Volume Series, Orono, 1-5.

1989b, Constructing Taphonomic Models: Theory, Assumptions, and Procedures in Bone Modification ed. Robson Bonnichsen e Marcella H. Sorg, Center for the study of first Americans, Peopling of the Americas Publications Edited Volume Series, Orono, 515-526.

Brain, C. K., 1989 The Evidence for Bone Modification by Early Hominids in Southern Africa, in Bone Modification, ed. Robson Bonnichsen e Marcella H. Sorg, Center for the study of first Americans, Peopling of the Americas Publications Edited Volume Series, Orono, 291-297.

Bruzek, J., 1991, Fiabilité des procédés de détermination du sexe à partir de l'os coxal. Application à l'étude du dimorphisme sexuel de l'homme fossile, Thèse de doctorat, Museum d'Histoire Naturelle, Institut de Paléontologie Humaine, Paris. 
Buikstra, J. e D. H. Ubelaker (eds),

1994 Standards: For Data Collection from Human Skeletal Remains - Proceedings of a Seminar at The Field Museum of Natural History Organized by Jonathan Haas, Arkansas Archaeological Survey Research Series No.44, Fayetteville.

Castro, M.W.M.,

2009 A Cronologia dos Sítios Lago do Iranduba e Laguinho à Luz das Hipóteses de Ocupação Humana para a Amazônia Central. Dissertação de mestrado. Museu de Arqueologia e Etnologia da Universidade de São Paulo.

Costa, J. A., D. C. Kern, M. L. da Costa, T. E. Rodrigues, N. Kämpf, J. Lehmann, F. J. L. Frazão,

2009 Geoquímica das Terras Pretas Amazônicas. in As Terras Pretas de Índio da Amazônia: sua caracterização e Uso deste Conhecimento na Criação de Novas Áreas. Editores Técnicos: W.G. Teixeira, D. C. Kern, B. E. Madari, W. Woods. Embrapa Amazônia Ocidental, 162-171.

Costa, F. W.,

2004 Estudo das Indústrias Líticas Pré-cerâmicas da Área de Confluência dos Rios Negro e Solimões. Museu de Arqueologia e Etnologia da Universidade de São Paulo.

2009 Arqueologia das Campinaranas do baixo rioNegro: em busca dos préceramistas nos areais da Amazônia Central. Tese de doutorado. Museu de Arqueologia e Etnologia da Universidade de São Paulo.

Costa, F. W. e Lima H. P.,

2006 Levantamento Arqueológico do Município de Manaus. Relatório encaminhado ao Ministério Público Federal e IPHAN. Manaus.

Costa, M. L. da, H. Behling, K Suguio, N. Kaempf, D. C. Kern, 2009 Paisagens Amazônicas so a Ocupação do Homem Pré-Histórico: Uma Visão Geológica. in As Terras Pretas de Índio da Amazônia: sua caracterização e Uso deste Conhecimento na Criação de Novas Áreas. Editores Técnicos: W.G. Teixeira, D. C. Kern, B. E. Madari, W. Woods. Embrapa Amazônia Ocidental, 15-38.

Denevan, W. M., 1996 A bluff model of riverine settlement in prehistoric Amazonia. Annals of the Association of American Geographers, 86 (4): 654-681.

2009 As Origens Agrícolas da Terra Mulata na Amazônia. in As Terras Pretas de Índio da Amazônia: sua caracterização e Uso deste Conhecimento na Criação de Novas Áreas. Editores Técnicos: W.G. Teixeira, D. C. Kern, B. E. Madari, W. Woods. Embrapa Amazônia Ocidental, 82-86.

Donatti, P. B.,

2002 Levantamento dos Sítios Arqueológicos Localizados nas Margens Norte do Lago Grande. Estudo do Sítio Lago Grande. Tese de Mestrado. Museu de Arqueologia e Etnologia, Universidade de São Paulo. 
Duday, H.,

1986 Contribution des observations ostélogiques à la chronologie interne des sépultures collectives in Anthropologie Physique et Archéologie: Méthodes d’Étude des Sépultures, Ed. Henri Duday et Claude Masset, Editions du CNRS, Paris, 51-54.

2005 L'archéotanatologie ou l'archéologie de la mort in Objets et Méthodes en Paleoanthropologie, Ed. Olivier Dutour, Jean-Jacques Hublin et Bernard van der Meersch, Comité des travaux historiques et scientifiques (CTHS), Paris, 153-216.

Duday, H e C. Masset (ed),

1986 Anthropologie Physique et Archéologie: Méthodes d'Étude des Sépultures. Editions du CNRS, Paris.

Dupras, T., J. Schultz, S. M. Wheeler e L. Williams,

2006 Forensic Recovery of Human Remains: Archaeological Approaches. Taylor and Francis Group, USA.

Farias, S. P., 2006 Análise dos Vestígios Faunísticos do Sítio Hatahara, Amazonas. Relatório Final de Iniciação Científica apresentado à FAPESP.

\section{Gifford-Gonzales, D.,}

1989 Analogues: Developing an Interpretive Framework in Bone Modification ed. Robson Bonnichsen e Marcella H. Sorg, Center for the study of first Americans, Peopling of the Americas Publications Edited Volume Series, Orono, 43-52.

Glaser, B. e W. I. Woods, (eds)

2004 Amazonian Dark Earths: Explorations in space and time. Berlim: Springer.

\section{Haglund, W. D.,}

2002 Recent Mass Graves, An Introuction, in. Advances in Forensic Taphonomy: Method, Theory and Archaeological Perspectives, Ed. William D. Haglund e Marcella H. Sorg, 243-261.

Haglund, W. D. e M. H. Sorg,

1997a Introduction to Forensic Taphonomy, in Forensic Taphonomy: The Postmortem Fate of Human Remains, Editado por W. Haglung e Marcella Sorg, CRC Press, USA, 1-9.

1997b Method and Theory of Forensic Taphonomy Research in Forensic Taphonomy: The Postmortem Fate of Human Remains, Editado por W. Haglung e Marcella Sorg, CRC Press, USA, 13-26.

Haynes, G., 1997 Foreword in Forensic Taphonomy: The Postmortem Fate of Human Remains: Editado por W. Haglung e Marcella Sorg, CRC Press, USA, xvii-xix.

Hilbert, P., 1968 Archäologische Untersuchungen Am Mittlern Amazonas, Berlim: Dietrich Reimer Verlag. 
Hillson, S.,

2002 Dental Anthropology. $3^{\text {rd }}$ Edition. Cambridge University Press. Cambridge.

Kipnis, R.,

2002 Foraging Societies of Eastern Central Brazil: An Evolutionary Ecological Study of Subsistence Strategies During the Terminal Pleistocene and Early/Middle Holocene, Tese de Doutorado. The University of Michigan.

Larsen, C. S.,

2000 Bioarchaeology: interpreting behavior from the human skeleton. Cambridge University Press.

\section{Lathrap, D.}

1970 The Upper Amazon, Praeger Publishers, New York.

1977 Our Father de Cayman, Our Mother the Gourd: Spinden Revisited, or a Unitary Model for the Emergence of Agriculture in the New World, in Origins of Agriculture, edited by C. A. Reed, pp. 713-752.

\section{Lehmann, J., D. C. Kern, B. Glaser e W. I. Woods}

2003 Amazonian dark earths: origins, properties, management. Dordrecht: Kluwer Academic Publishers.

Lewis, M. E.

2007 The bioarchaeology of children: perspectives from biological and forensic anthropology. Cambridge University Press.

Lima, H. P.,

2004 Cronologia da Amazônia Central: O significado da variabilidade da fase Manacapuru. MAE/USP/FAPESP, São Paulo.

2005 Cronologia da Amazônia Central: o significado da variabilidade da

fase Manacapuru. Qualificação de Mestrado. Museu de Arqueologia e Etnologia da Universidade de São Paulo.

2008 História das caretas: a tradição borda incisa na Amazônia central, Tese de Doutorado, Museu de Arqueologia e Etnologia da Universidade de São Paulo.

Lima, H. P., E. G. Neves e J. B. Petersen,

2006 A Fase Açutuba: Um Novo Complexo Cerâmico na Amazônia Central in Arqueología Suramericana, Popayan - Colômbia, v. 2, n. 1, 26-52.

\section{Lowie, $\mathbf{R}$.}

1948 The Tropical Forests : An Introduction in Handbook of South American Indians, Editor Julian H. Steward - Smithsonian Institution Bureau of American Ethnology, United States Printing Office, Bulletin 143, Vol. 3, pp. 1 - 56, Washington. 
Lyman, L. e G. Fox,

1997 A Critical Evaluation of Bone Weathering as an Indication of Bone Assemblage Formation in Forensic Taphonomy: The Postmortem Fate of Human Remains, Editado por W. Haglung e Marcella Sorg, CRC Press, 223-247.

Macedo, R. S., W. G. Teixeira e G. C. Martins

2007 Caracterização de dois perfis com horizonte antrópico (Terra Preta de Índio) no Lago do Limão - AM. In XII Congresso de Abequa: Estudos do quaternário e responsabilidade sócio-ambiental, Belém-PA. XII Congresso da Abequa: Estudos do quaternário e responsabilidade sócio-ambiental.

Machado, J. S.,

2002 Estudo de uma Estrutura Funerária Presente no Sítio Hatahara, Estado do Amazonas. Relatório Final de Iniciação Científica apresentado à FAPESP, 2002.

2005 Montículos Artificiais na Amazônia Central: Um Estudo de Caso do Sítio Hatahara. Tese de Mestrado, Museu de Arqueologia e Etnologia da Universidade de São Paulo.

Machado, L. C., 2006a Sítio Cemitério dos Pretos Novos: análise biocultural. Interpretando os ossos e os dentes humanos in Boletim do Instituto de Arqueologia Brasileira (IAB), nํ12, 124.

2006b Os Sepultamentos, Contextos Arqueológicos e Dados Bioesqueletais in Boletim do Instituto de Arqueologia Brasileira (IAB), nํㅜㄹ, 25-33.

Marinho, A. N. do R, N. C. Miranda, V. Braz, Â. K. Ribeiro-dos-Santos e S. M. F. M. de Souza,

2006 Paleogenetic and taphonomic analysis of human bones from Moa, Beirada, and Zé Espinho Sambaquis, Rio de Janeiro, Brazil in Mem. do Instuto Oswaldo Cruz, Rio de Janeiro, Vol. 101(Suppl. II): 15-23.

Martin, R. E.,

1999 Taphonomy: A Process Approach, Cambridge, Paleobiology Series 4.

Masset, C.,

1986 Le Recrutement d'un ensemble funéraire in Anthropologie Physique et Archólogie: Méthodes d’Étude des Sépultures, Ed. Henri Duday et Claude Masset, Editions du CNRS, Paris, 111-126.

Marshall, L. G.,

1989 Bone modification and 'the laws of burial' in Bone Modification ed. Robson Bonnichsen e Marcella H. Sorg, Center for the study of first Americans, Peopling of the Americas Publications Edited Volume Series, Orono.

Meggers, B. J., Evans, C.,

1957 Archeological Investigations at the mouth of the Amazon, Smithsonian Institution Bureau of American Ethnology, Government Printing Office, Bulletin 167, Washington. 
1961 An Experimental Formulation of Horizon Styles in the Tropical Forest Area of South America. in Lothrop S. K., org., Essays in Pre-Colombian art and archaeology, Cambridge, Harvard University Press, 372-388.

Moraes, C. P.,

2003 Levantamento Arqueológico das Margens do Lago do Limão, Município de Iranduba. Projeto encaminhado a FAPESP. MAE/USP, São Paulo.

2006 Arqueologia na Amazônia Central Vista de Uma perspectiva da Região do Lago do Limão, Tese de Mestrado, Museu de Arqueologia e Etnologia da Universidade de São Paulo.

Müller, L. M.,

2008 Sobre índios e ossos: estudo de três sítios de estruturas anelares construídos para enterramento por populações que habitavam o vale do rio Pelotas no período pré-contato. Dissertação de mestrado. Pontifícia Universidade Católica do Rio Grande do Sul.

Neves, E. G., 1998 Paths in Dark Waters: archaeology as indigenous history in the Upper Rio Negro Basin, Northwest Amazon. Tese de doutorado. Indiana University.

2000 Levantamento arqueológico da área de confluência dos rios Negro e Solimões, estado do Amazonas. USP/FAPESP. Relatório, São Paulo.

2001 Indigenous Historical Trajectories in the Upper Rio Negro Basin in Unknown Amazon. Culture in Nature in Ancient Brazil, edited by C. McEwan, C. Barreto and E. G. Neves, 1st ed. The British Museum Press, London, 256-286.

2006 Arqueologia da Amazônia, Jorge Jahar Editor.

Neves, E. G. e F. W. Costa,

2001 Resgate Emergencial do Sítio Arqueológico Nova Cidade, Manaus - AM (parte 1). Relatório encaminhado ao Ministério Público Federal e IPHAN. Manaus.

Neves, E. G., M. Arroyo-Kalin, R.Bartone, F. W. S. Costa, P. Bayod Donatti, B. Glaser, J. S. Machado, C. J. Munita, L. F. E. Lima, J. B. Petersen, H. P. Lima, L. Rebellato, C. A. da Silva, E. A. Soares.

2003 Relatório de Atividades, Relatório Científico apresentado à FAPESP.

Neves, E. G., Castro, M.W.M., Lima, H. P., Costa, F. W., Rapp Py-Daniel, A., 2007 Relatório de Atividades, Relatório Científico apresentado à FAPESP.

Neves, E. G., F. Ozório de Almeida, A. Rapp Py-Daniel, S. Cunha Lima, C. Fernandes Caromano, L. Mathews Cascon,

2009 Relatório de Atividades, Relatório Científico apresentado à FAPESP.

Neves, E. G. e J. B. Petersen, 
2006 Political Economy and Pre-Columbian: Landscape Transformation in Central Amazonia in Time and Complexity in Historical Ecology - Studies in the Neotropical Lowlands, ed. William Ballée e Clark L. Erickson, Columbia University Press, New York, 279-309.

Neves, E. G., J. Petersen, R. Bartone e C. A. da Silva,

2003 Historical and socio-cultural origins of Amazonian Dark Earths in Amazonian Dark Earths: Origin, properties, management, ed. by J. Lehmann, D. C. Kern, B. Glaser e W. Woods, Kluwer Academic Publishers, Dordrecht, 29 - 50.

Neves, W. A.,

1984 Paleogenética dos Grupos Pré-históricos do Litoral Sul do Brasil (Paraná e Santa Catarina), Tese doutorado, Universidade de São Paulo.

Neves Junior, A. F.

2008 Qualidade física de solos com horizonte antrópico (Terra Preta de Índio) na Amazônia Central. Tese de doutorado. Escola Superior de Agricultura "Luiz Queiroz”. Universidade de São Paulo, Piracicaba.

\section{Nordby, J. J.,}

2002 Is Forensic Taphonomy Scientific? in. Advances in Forensic Taphonomy: Method, Theory and Archaeological Perspectives, Ed. William D. Haglund e Marcella H. Sorg, 31-42.

Petersen, J. B., E. G. Neves e M. J. Heckenberger,

2001 Gift from the past: terra preta and prehistoric occupation in Amazonia. In Unknown Amazon. Culture in Nature in Ancient Brazil, edited by C. McEwan, C. Barreto e E. G. Neves, 1st ed. The British Museum Press, London, 86-107.

Petersen, J. B., E. G. Neves e W. I. Woods, 2005 Tropical Forest Archaeology in Central Amazonia: Landscape Transformation and Sociopolitical Complexity. Paper presented at the 70th annual meeting of the Society for American Archaeology, Salt Lake City.

Plens, C. R.,

2007 Sítio Moraes, uma biografia não autorizada: análise do processo de formação de um sambaqui fluvial. Museu de Arqueologia e Etnologia da Universidade de São Paulo.

Portocarrero, R. A. C., 2007 A variabilidade especial no sítio Osvaldo: estudo de um assentamento da Tradição Barrancóide na Amazônia Central. Dissertação de mestrado. Museu de Arqueologia e Etnologia da Universidade de São Paulo.

Rapp Py-Daniel, A.,

2008 Arqueologia da Morte no Sítio Hatahara durante a Fase Paredão, Memorial de Qualificação. Museu de Arqueologie e Etnologia da Universidade de São Paulo. 
Rapp Py-Daniel, A., B. M. Moraes, E. G. Neves, H. P. Lima, L. M. da Silva, F. V. Nunes, L. C. da Silva,

2009 Prospecção e Resgate Emergencial no Sítio Arqueológico Hatahara - AM-IR13. Relatório Final apresentado ao IPHAN.

Rebellato, L.,

2007 Interpretando a Variabilidade Cerâmica e as Assinaturas Químicas e Físicas do Solo no Sítio Arqueológico Hatahara. Tese de Mestrado, Museu de Arqueologie e Etnologia da Universidade de São Paulo.

Renfrew, C. e P. Bahn,

1991 Archaeology: theories, methods, and practice. Thames and Hudson. New York.

Rodrigues, C.C. e S.M.F. Mendonça de Souza,

1998 Uso de adornos labiais pelos construtores do sambaqui de Cabeçuda, Santa Catarina, Brasil: Uma Hipótese baseada no perfil dento-patológico. Revisto de Arqueologia da SAB, 11. 45-55.

\section{Roksandic, M.,}

2002 Porition of Skeletal Remains as a Key to Understanding Mortuary Behavior in. Advances in Forensic Taphonomy: Method, Theory and Archaeological Perspectives, Ed. William D. Haglund e Marcella H. Sorg, 99-117.

Scott, G. R, e C. G. Turner,

1997 The Anthropology of Modern Human Teeth: Dental Morphology and Its Variation in Recent Human Populations. New York: Cambridge University Press.

Scheuer, L. e S. Black, 2000, Developmental Juvenile Osteology, Academic Press.

\section{Schmitt, A.,}

2005 Une Nouvelle Méthode pour Estimer l'âge au Décès des Adultes à partir de la Surface Sacro-pelvienne Iliaque in Bulletins et Mémoires de la Société d'Anthropologie de Paris, Paris, n.s., t. 17, 1-2.

Silva, A. B. A.,

1977 A Civilização Indígena do Uaupés. Roma, Itália, Congregação Salesiana.

Silva, F. S. M. da, 2005 Arqueologia das práticas mortuárias em Sítios pré-históricos do Litoral do Estado de São Paulo. Tese de Doutorado, Universidade de São Paulo.

\section{Sorg M. H. e W. D. Haglund,}

2002 Advancing Forensic Taphonomy: Purpose, Theory and Practice, in. Advances in Forensic Taphonomy: Method, Theory and Archaeological Perspectives, Ed. William D. Haglund e Marcella H. Sorg, 3-30. 
Souza, S. M. F. M. de, V. Guapindaia, C. D. Rodrigues, C. D.,

2001 A Necrópole Maracá e os Problemas Interpretativos em um Cemitério Sem Enterramentos. Boletim do Museu Paraense Emílio Goeldi, BELÉM, v. 17, n. 2, 479520.

\section{Steward, J. H.}

1948 Culture Areas of the Tropical Forests. in Handbook of South American Indians, Editor Julian H. Steward - Smithsonian Institution Bureau of American Ethnology, United States Printing Office, Bulletin 143, Vol. 3, pp. 883 - 899, Washington.

Tamanaha, E. K., 2006 Estudo de uma Estrutura Artificial no Sítio Hatahara, rio Solimões, Estado do Amazonas. Relatório final de iniciação científica apresentado a FAPESP.

Tamanaha, E. K e A. Rapp Py-Daniel,

2009 Sítio Hatahara: estruturas funerárias, residenciais ou ambas?, Revista do Museu de Arqueologia e Etnologia - USP.

Tamura, A. T. A., 2005 A Ocupação Pré-Colonial do Sítio Arqueológico Lago Grande. Relatório final de iniciação científica apresentado à FAPESP.

Tappen, M.,

1994 Bone Weathering in the Tropical Rain Forest in Journal of Archaeological Science 21, 667-673.

Teixeira, W. G., G. C. Martins, R. S. Macedo, A. F. Neves Junior, A. Moreira, V. M. Benites e C. Steiner, 2009 As Proprioedades Físicas e Hídricas dos Horizontes Antrópicos das Terras Pretas de Índio na Amazônia Central. in As Terras Pretas de Índio da Amazônia: sua caracterização e Uso deste Conhecimento na Criação de Novas Áreas. Editores Técnicos: W.G. Teixeira, D. C. Kern, B. E. Madari, W. Woods. Embrapa Amazônia Ocidental, 242-250.

Teixeira, W. G., D. C. Kern, B. E. Madari e W. Woods, (Editores Técnicos)

2009 As Terras Pretas de Índio da Amazônia: sua caracterização e Uso deste Conhecimento na Criação de Novas Áreas. Embrapa Amazônia Ocidental.

Ubelaker, D. H., 1979 Skeletal Evidence for Kneeling in Prehistoric Ecuador in American Journal of Physical Anthropology 51: 679-686.

1997 Taphonomic applications in forensic anthropology in Forensic Taphonomy. The Postmortem Fate of Human Remains, Haglund, W.D. and M. H. Sorg (eds.). CRC Press, New York, 77-90.

1999 Human Skeletal Remains - Excavation, Analysis, Interpretation, Terceira Edição, Manuals on Archeology 2, Taraxacum - Washington. 
Wesolowski, V.,

2007 Cáries, desgaste, cálculos dentários e micro-resíduos da dieta entre grupos préhistóricos do litoral norte de Santa Catarina: É possível comer amido e não ter cárie? Tese de Doutorado, Fundação Oswaldo Cruz - Escola Nacional de Saúde Pública Arouca.

White, T. D. e P. A. Folkens,

2000 Human Osteology, Second Edition, Academic Press.

White, E. M. e L. A. Hannus,

1983 Chemical Weathering of Bone in Archaeological Soils in American Antiquity, Vol. 48, No. 2. (Apr., 1983), 316-322.

\section{Woods, W.}

2009 Os Solos e as Ciências Humanas: Interpretação do Passado. in As Terras Pretas de Índio da Amazônia: sua caracterização e Uso deste Conhecimento na Criação de Novas Áreas. Editores Técnicos: W.G. Teixeira, D. C. Kern, B. E. Madari, W. Woods. Embrapa Amazônia Ocidental, 62-71.

\section{Woods, W. e W. Denevan,}

2006 Discovery, Study, and bibliography of Amazonian Dark Earths, 1870-1970. in Ethno and Historical Geographic Studies in Latin American: Essays Honoring William V. Davidson. P. H. Herlihy e C. S. Revels (eds). Baton Rouge: Geoscience Publications (Published in 2008). 283. 
ANEXOS 
SÍTIO ARQUEOLÓGICO HATAHARA

$$
\text { AM-IR-13 }
$$

Município de Iranduba - AM

\begin{tabular}{|c|c|c|c|c|c|}
\hline \multicolumn{6}{|c|}{ LEGENDA } \\
\hline (1.) & Unidade & - - & Cerca & 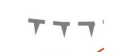 & Borda de superficie aplainada (aproximada) \\
\hline 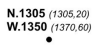 & Tradagem & $\square$ & Edificação & $40=$ & Curvas de nivel ( $m$ ) \\
\hline . & Tradagem - Solo & $\Phi_{M-1}$ & Marco de ferro & $=$ & "Monticulo" \\
\hline$\cdots$ & Transect & - & Árvore & 等i & Capoeira antiga \\
\hline$\overline{\bar{c}}:=$ & Estrada & A $\quad$ B & Linha do perfil & in & Cultura / Pasto \\
\hline
\end{tabular}

coosiseng

\begin{tabular}{|c|c|c|c|c|}
\hline \multicolumn{4}{|c|}{ COORDENADAS DOS MARCOS DE FERRO } & \\
\hline MARCO & Norte $(\mathrm{m})$ & Oeste (r) & \begin{tabular}{l|l|}
$11)$ & Alt. (m) \\
\end{tabular} & \\
\hline$\frac{M-1}{M-2}$ & \begin{tabular}{|l|l|l|l|l|l|}
1152,00 \\
116700
\end{tabular} & $\left|\begin{array}{l}1362,00 \\
136200\end{array}\right|$ & $\begin{array}{ll}48,20 \\
4797\end{array}$ & 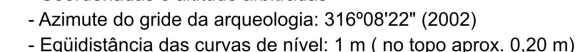 \\
\hline $\mathrm{M}-3$ & $10^{1670}$ & & 4760 & \\
\hline
\end{tabular}

UNIDADES ESCAVADAS

(1) N.115211160-W.1360- Trinchira

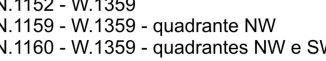

(2) $N .1137(1137.50)-W .1360$ (1358,95)

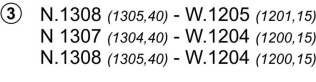

(4) N. 1321 (1329.50)-W. 13000 (1329.00

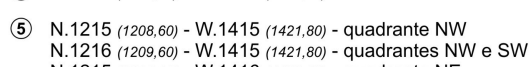

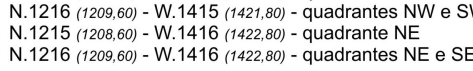

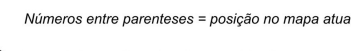

(6) Local Aproximado das unidadese escavadas no monticulo III

$$
N \text { do grid }
$$

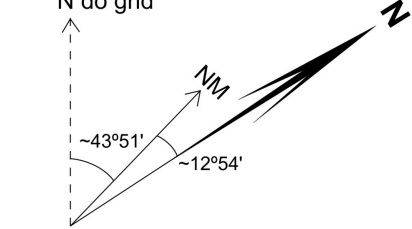

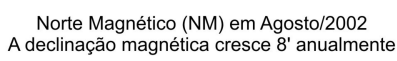

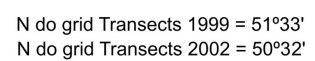

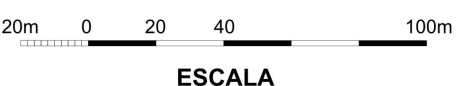
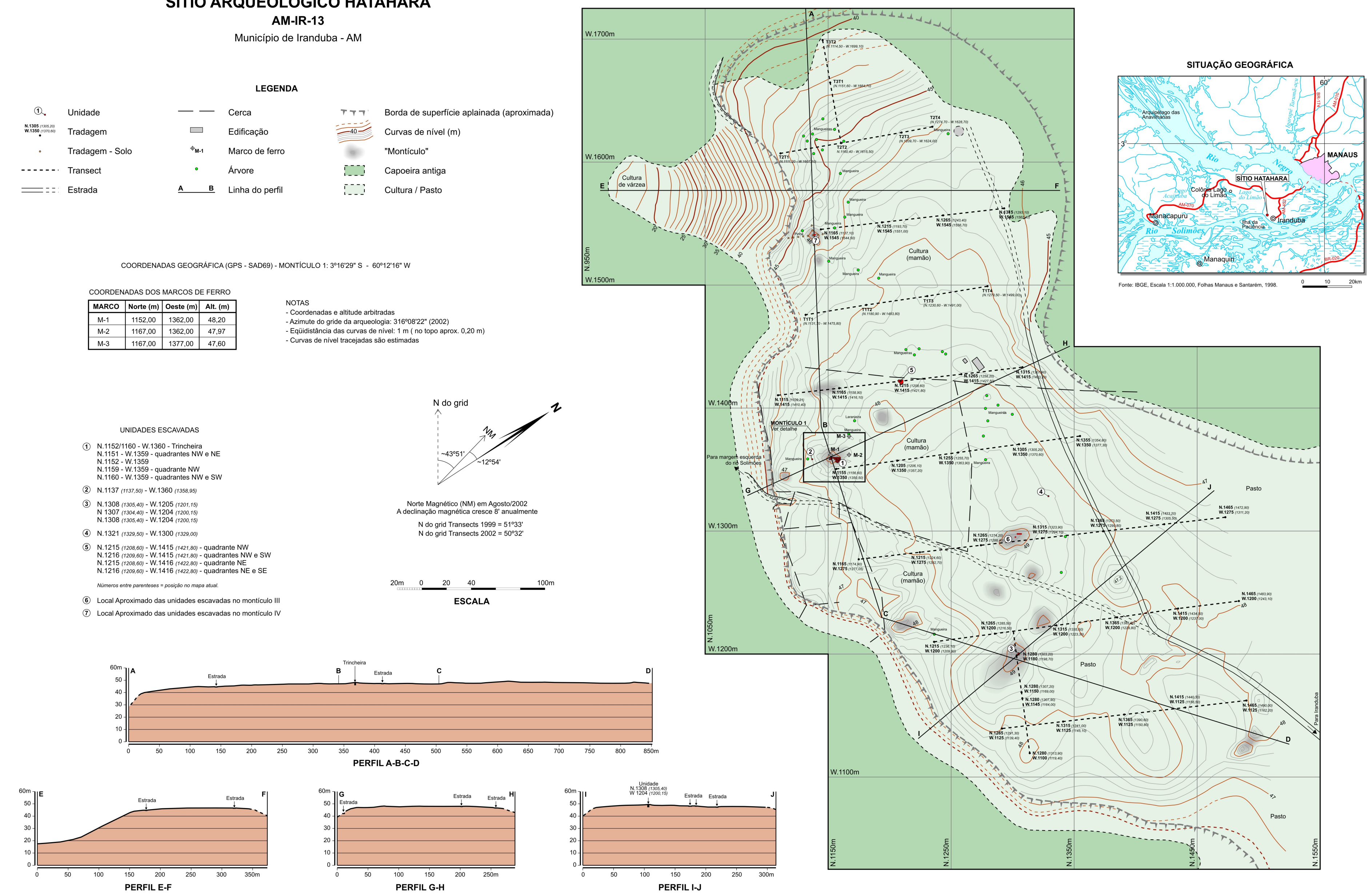

FEFIL

PERFIL I-J

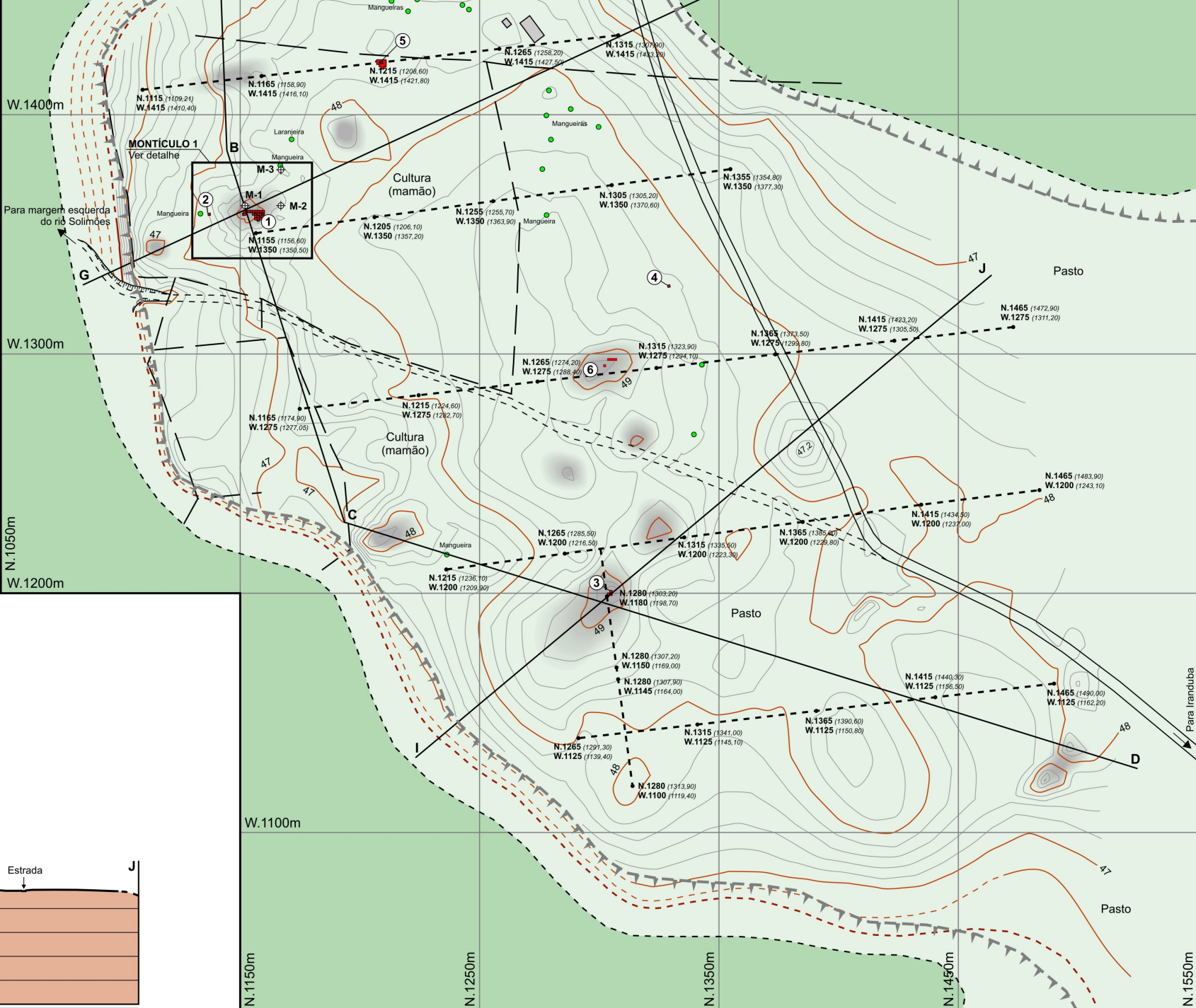

Anexo 1: Mapa do Sítio Hatahara. Parcialmente atualizado até 2008. Mapa realizado a partir de M.E.B. Castro 2006 


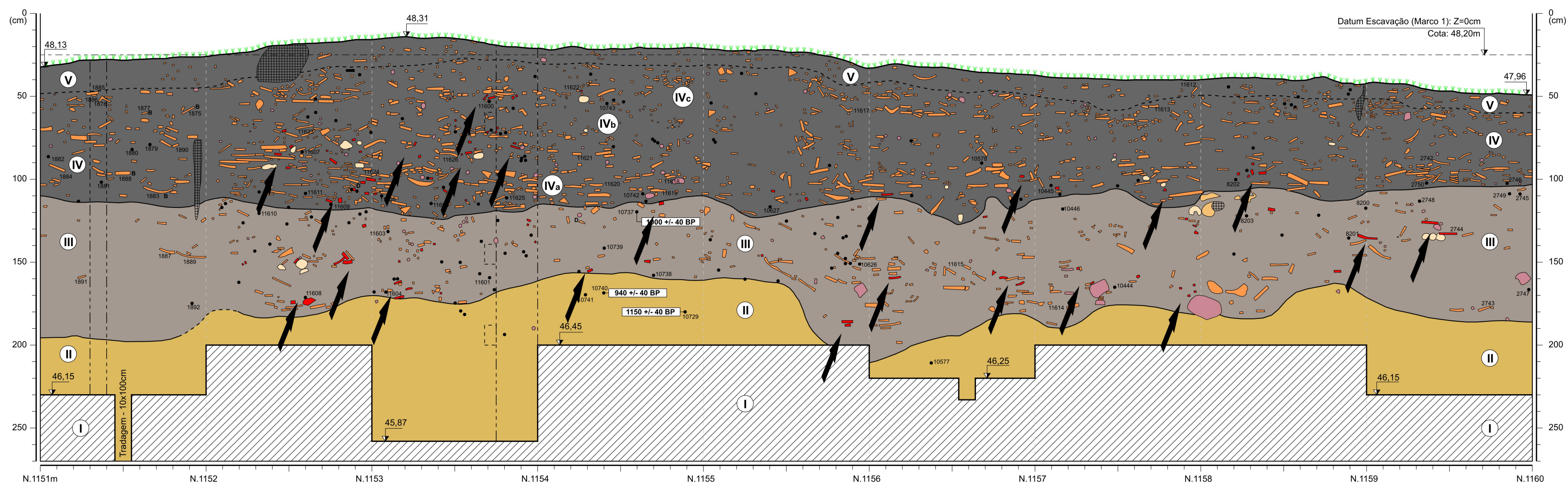

\begin{tabular}{cl}
$\triangle$ & Fragmentos de cerâmica \\
- & Ossos \\
$\cdot$ & Carvão \\
00 & Rocha / Laterita \\
00 & Argila \\
\hline $1000+1 / 40$ BP & Datacão ${ }^{14} \mathrm{C}$ \\
${ }_{\text {B }}$ & Fragmento de borda \\
${ }^{\circ} \quad$ & Fragmento com decoração \\
${ }_{1888}$ & Número de proveniência
\end{tabular}

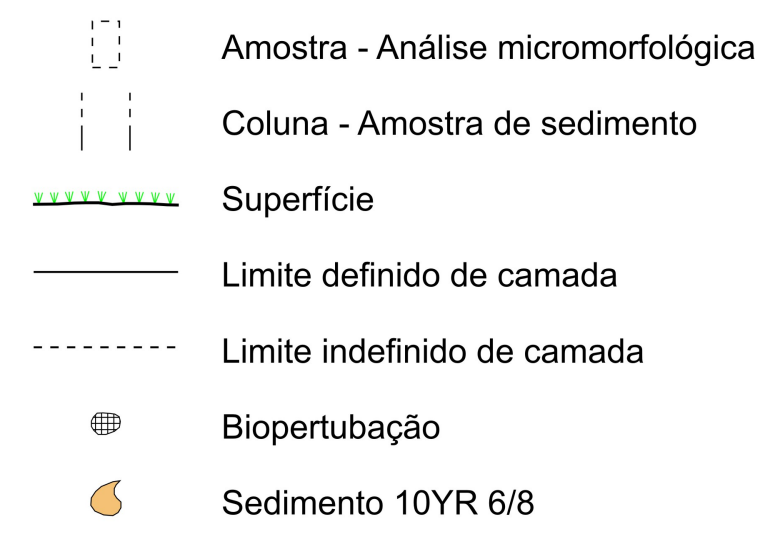

(вев $\quad$ Número de proveniência
— (v) 10YR 2/1 - "Black", média densidade cerâmica, areno-argiloso.

(IV) 10YR 2/1 - "Black", alta densidade cerâmica, argilo-arenoso. Montículo artificial, composto por 3 subcamadas: a) Alta densidade cerâmica com baixo grau de fragmentação alinhadas horizontalmente; b) Média densidade cerâmica com alto grau de fragmentação; c) Alta densidade cerâmica com médio grau de fragmentação alinhados horizontalmente.

(III) 10YR 2/1 - "Black", média densidade cerâmica, argilo-arenoso. Presença de estruturas de combustão, feições com alta densidade de vestígios faunísticos, cerâmica e carvão e, presença de sepultamentos diretos e em urna.

III De 10YR 6/8 mosqueado (80\%) com 10YR 3/2 "brownish yellow", até 10YR 3/2 mosqueado a $(90 \%)$ com $10 \mathrm{YR} 6 / 8$ "very dark grayish brown", baixa densidade cerâmica, argiloso.

VIA (1) 10YR 6/8 - "Brownish yellow", camada estéril, argiloso. Área parcialmente escavada.

Anexo 2: Perfil Oeste da trincheira escavada até 2002. Flechas indicam presença de vestígios ósseos. Desenho adaptado de M.E.B. Castro. 


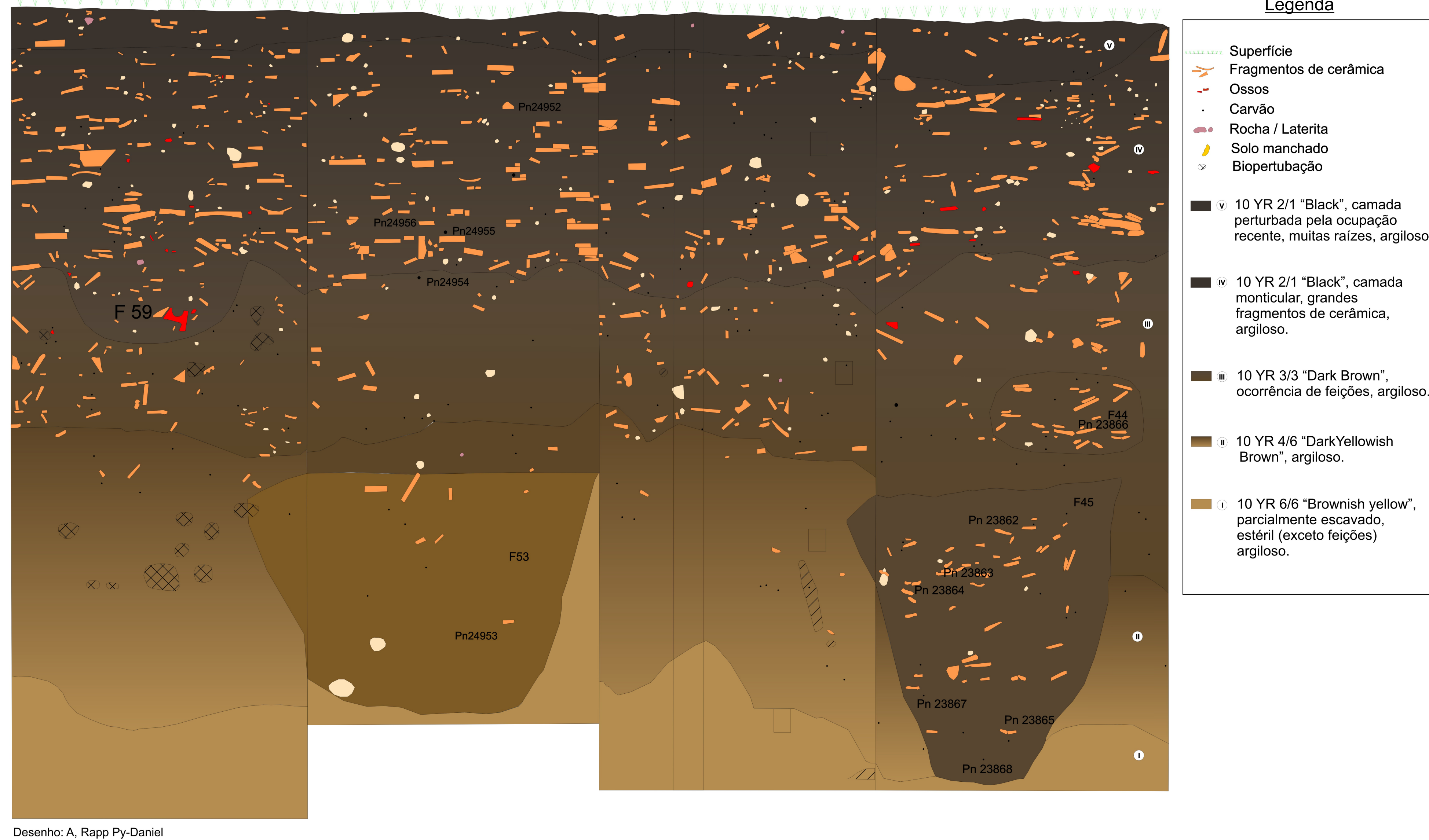




\section{Anexo 4: Ficha de Desmontagem}

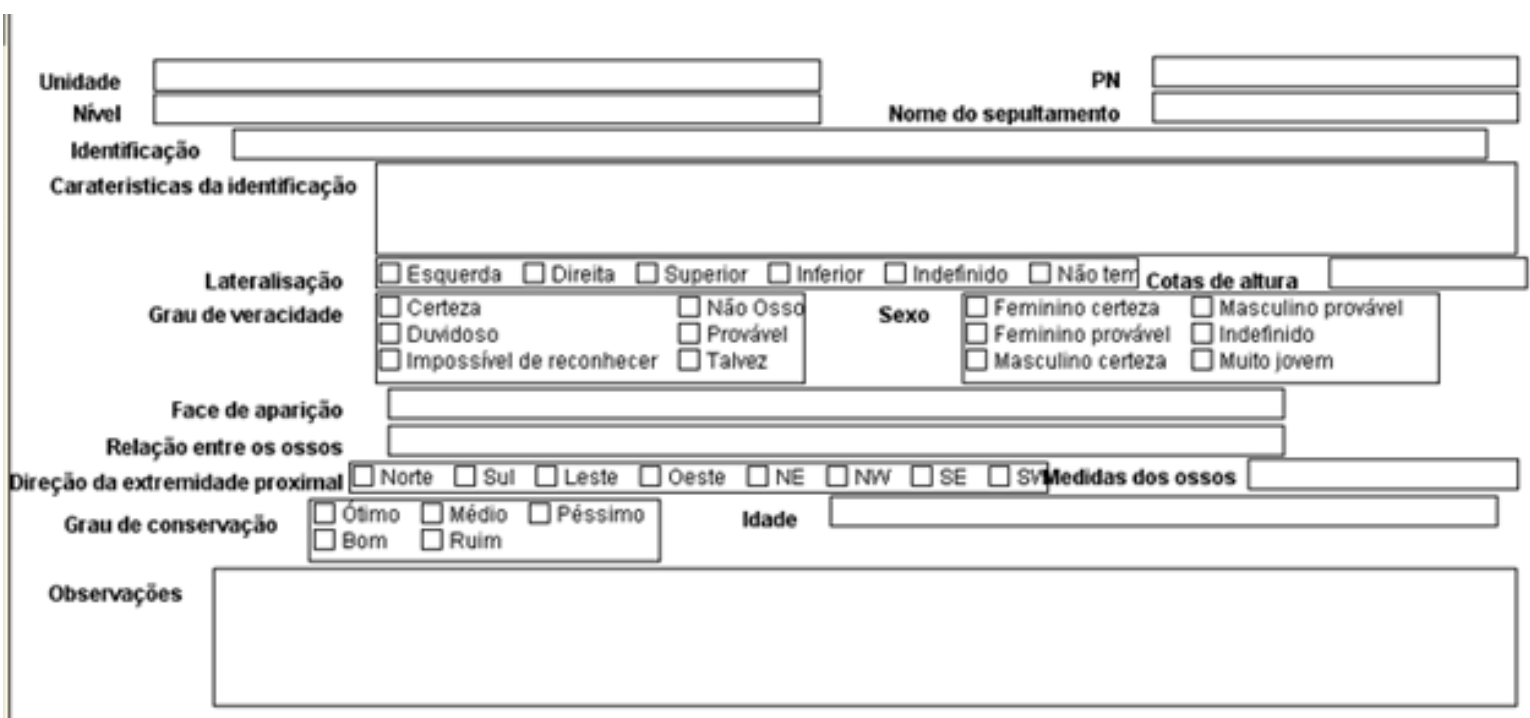





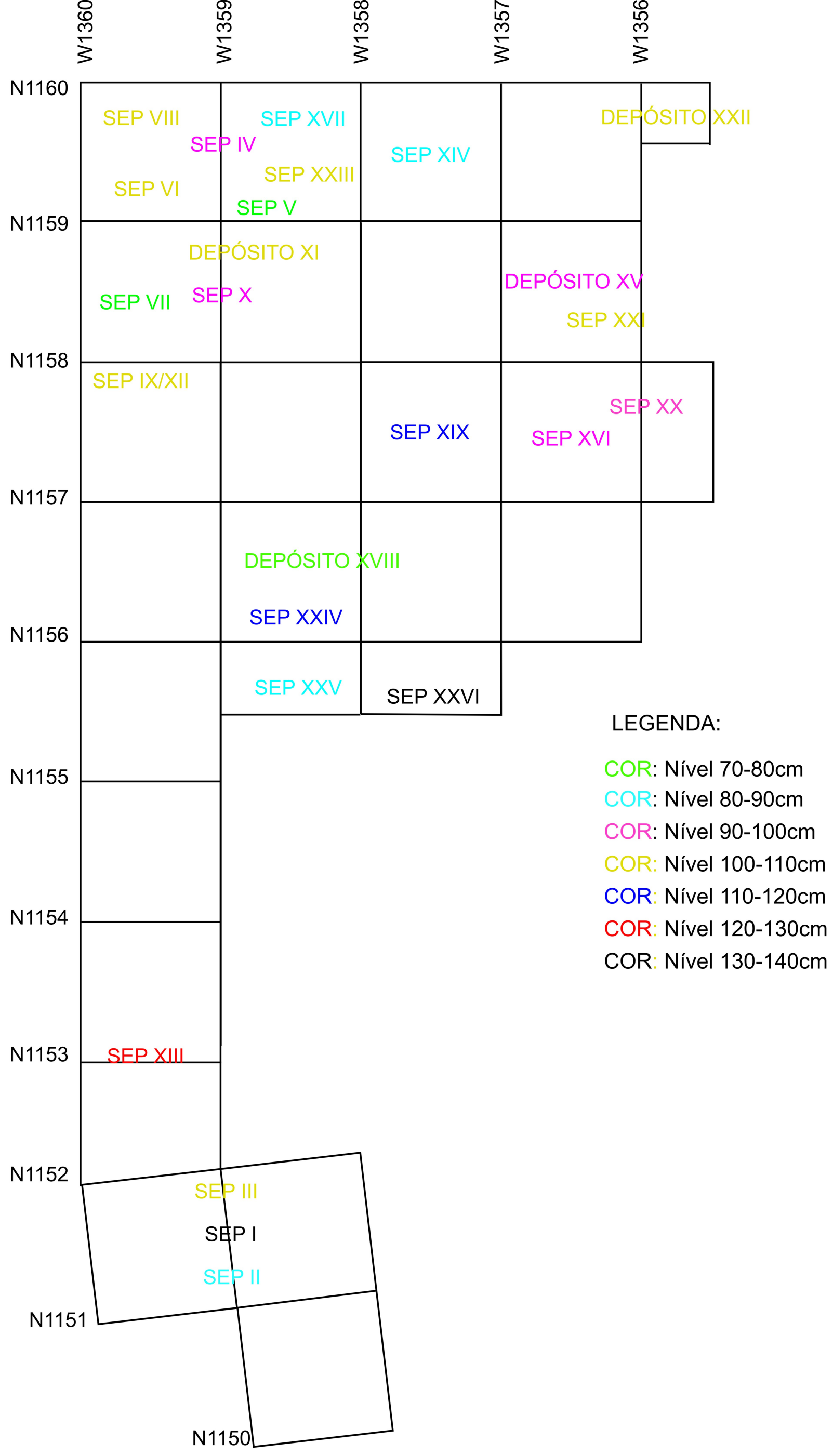

Anexo 6: Profundidade dos sepultamentos escavados no montículo 